UNIVERSIDADE DE SÃO PAULO

INSTITUTO DE RELAÇÕES INTERNACIONAIS

PROGRAMA DE PÓS-GRADUAÇÃo

NÍVEL: DOUTORADO

OS ENTRELAÇAMENTOS DE ORDENS LEGISLATIVAS: A ANÁLISE CRÍTICA DA DIPLOMACIA PARLAMENTAR E DO PROCESSO LEGISLATIVO NOS CASOS UNIÃO EUROPEIA/ESTADOS-MEMBROS E FIFA/BRASIL

Orientadora: Dra. Deisy de Freitas Lima Ventura

Durante o desenvolvimento deste trabalho, o autor recebeu auxílio financeiro da FAPESP - Fundação de Amparo à Pesquisa do Estado de São Paulo 


\title{
OS ENTRELAÇAMENTOS DE ORDENS LEGISLATIVAS: A ANÁLISE CRÍTICA DA DIPLOMACIA PARLAMENTAR E DO PROCESSO LEGISLATIVO NOS CASOS UNIÃO EUROPEIA/ESTADOS-MEMBROS E FIFA/BRASIL
}

\author{
CICERO KRUPP DA LUZ
}

TESE apresentada como requisito para obtenção do título de Doutor em Ciências - Programa de Pós-Graduação do Instituto de Relações Internacionais da Universidade de São Paulo.

Linha de pesquisa: Cultura e Questões Normativas nas Relações Internacionais

Sublinha: Ordem, Democracia e Governança Global. 


\section{AGRADECIMENTOS}

Ao Leo Francisco da Luz, Eleusa Krupp da Luz e Natan krupp da Luz, meus amores.

Agradecimento ao apoio da FAPESP - Fundação de Amparo à Pesquisa do Estado de São Paulo, pelo fomento.

Ao Instituto de Relações Internacionais da Universidade de São Paulo, pela oportunidade.

Aos amigos, pela vida ser.

Aos professores pelo conhecimento, crítica e dedicação.

Em especial à orientadora Deisy Ventura pela confiança, inspiração política e intelectual. 
Eu vou dizer uma coisa que é loucura, mas menos democracia, às vezes, é melhor para organizar uma Copa do Mundo.

Jérôme Valcke, Secretário-Geral da FIFA 


\section{RESUMO}

Os entrelaçamentos de ordens legislativas envolvem o cruzamento de estruturas jurídicopolíticas de diferentes níveis: internacional, transnacional, supranacional e nacional. A análise dos entrelaçamentos pela perspectiva da diplomacia parlamentar e do processo legislativo geram uma capacidade de avaliação crítica em torno se de sua legitimidade. A tese tem como tema o Poder Legislativo, um dos pilares da prática democrática da grande maioria dos Estados do século XXI, assegurando a representação no processo político. O Poder Legislativo consiste na delegação soberana e legítima de fazer a lei aplicável em um determinado território. Ainda que consolidado no âmbito das constituições nacionais, o Poder Legislativo não tem sido estudado, no plano internacional. Contudo, a crescente incorporação de normas internacionais ao nível doméstico suscita a questão da legitimidade democrática da criação dessas normas, sendo trabalhado por seus dois elementos constituintes: processo e representação legislativa. O processo legislativo é entendido como ideologia, pois mesmo como procedimento ou forma é identificado com uma estrutura de poder que prioriza certos resultados. A sua análise é proposta pela exploração de entre ordens legislativas nacionais e extranacionais. A representação legislativa é abordada por meio do conceito de diplomacia parlamentar, que engloba uma série desordenada de atividades e poderes de parlamentares ou processos parlamentares nas relações internacionais. Sendo assim, esse conceito será sistematizado, primeiramente por dois níveis: o nível democrático por meio de um código eleito/não-eleito; e um segundo nível por suas funções: legislativa, fiscalizadora e/ou diplomática. Como base teórica, busca-se abrigo no transconstitucionalismo e o abrigo da teoria crítica das relações internacionais. Como método, utiliza-se uma revisão teórica com exploração de estudos de casos. Os casos exploram a existência de entrelaçamento de ordens legislativas em duas relações: supranacional/nacional e transnacional/nacional. Contudo, produzem resultados opostos. Enquanto a União Europeia apresenta um entrelaçamento constituído por processos transparentes, legítimos e dotados de mecanismos de participação, na relação entre suas instituições supranacionais e os Estados-membros, a lex sportiva do futebol produz um entrelaçamento opaco, ilegítimo e hermético à participação na relação da sua ordem transnacional e o processo legislativo estatal brasileiro.

Palavras-chave; Diplomacia Parlamentar; Processo Legislativo; transconstitucionalismo; União Europeia. FIFA; 


\begin{abstract}
The interlacements of legislatives orders involve the legal and political structures crossing of different levels: international, transnational, supranational and national. The interlacements analysis through the parliamentary diplomacy and legislative outlook generate a critical assessment capacity around its legitimacy. The thesis' theme is the Legislative Power, one of the pillars of democratic practice of the vast majority of states in the twenty-first century, ensuring representation to the political process. The Legislative Power consists in the sovereign and legitimate delegation to making the law applicable in a given territory. Although funded in national constitutions, the Legislative Power has not been studied in international relations. However, the increasing incorporation of international law at the domestic level raises the question of the democratic legitimacy of the development of such norms. Therefore, it will be developed by its two founding concepts: process and legislative representation. The legislative process is understood as ideology, because even as a procedure or form it is identified as a structure power that prioritizes given results. Its analysis is proposed by exploring the national and extranational legal orders. The legislative representation is addressed through the concept of parliamentary diplomacy which includes a disorderly series of activities and powers of parliament or parliamentary procedures in international relations. Thus, this concept will be systematized by two levels: first, the democratic level with an unelected/elected code; and a second level concerning its functions: legislative, accountable and/or diplomatic. As a theoretical basis, we seek shelter in transconstitutionalism and the critical theory of international relations. As a method, it is used a theoretical review on exploration of case studies. The cases explore the existence of interlacements of political orders in two relationships: supranational/national and transnational/national. However, it produces opposite results. While the European Union has an interlacement consisting, transparent, legitimate and endowed with mechanisms of participation, with the relationship between supranational institutions and their Member States, the football lex sportiva produces interlacement opaque, illegitimate and hermetic in relation to the participation of its transnational order with the Brazilian state legislative process.
\end{abstract}

Keywords: Parliamentary Diplomacy; Legislative Process; Transconstitutionalism; Europe Union; FIFA. 


\section{Sumário}

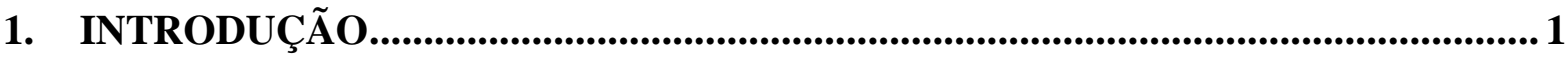

2. PODER LEGISLATIVO EXTRANACIONAL: PROCESSO LEGISLATIVO E

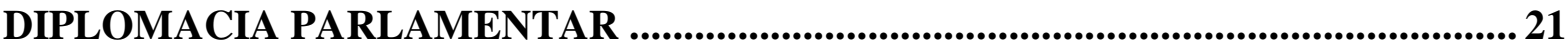

2.1. O Processo Legislativo Extranacional .............................................................................24

2.1.1 A crítica à separação de poderes e à teoria das fontes........................................................ 29

2.1.2 Sintomas e novos pontos de partida ..................................................................................38

2.1.3 Transconstitucionalismo e Sistema Político .................................................................. 42

2.1.4 Entrelaçamentos como Processo ................................................................................... 45

2.2 A Diplomacia Parlamentar: democratização e função ………………………………...... 50

2.2.1. Contornos para uma classificação ....................................................................................5 58

2.2.2 Diplomacia Parlamentar Não-Eleita........................................................................62 62

2.2.3 Diplomacia Parlamentar Eleita de Função Diplomática ..................................................... 65

2.2.4 Diplomacia Parlamentar eleita de Função de Fiscalização .................................................. 74

3. OS ENTRELAÇAMENTOS DE ORDENS LEGISLATIVAS

SUPRANACIONAL/NACIONAL: UNIÃO EUROPEIA/ESTADOS-MEMBROS....... 82

3.1 As Estruturas Supranacionais da União Europeia ......................................................... 84

3.1.1 As mudanças a partir do Tratado de Lisboa ...................................................................... 85

3.1.2 A opção da União Europeia pela diplomacia parlamentar .................................................87

3.2 O Entrelaçamento Legislativo da União Europeia ....................................................... 92

3.2.1 A Iniciativa Legislativa .................................................................................................95

3.2.2 Debate e aprovação Legislativa ......................................................................................98

4. OS ENTRELAÇAMENTOS DE ORDENS LEGISLATIVAS TRANSANACIONAL/ NACIONAL: O EQUIVALENTE FUNCIONAL LEGISLATIVO DO CASO

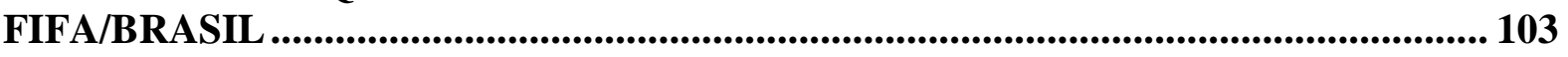

4.1 Do conceito de bem público à ordem transnacional da lex sportiva .......................... 111

4.1.1 Futebol como bem público global............................................................................. 112

4.1.2 A ordem transnacional da lex sportiva e a FIFA ............................................................. 118

4.2 O Entrelaçamento Legislativo FIFA/BRASIL ............................................................. 133

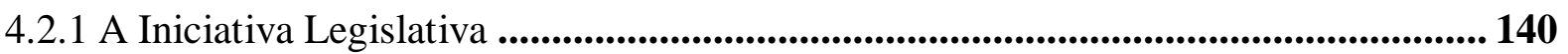

4.2.2 Debate e aprovação Legislativa ......................................................................................... 152

5. RESULTADOS E CONSIDERAÇÕES FINAIS ....................................................... 166

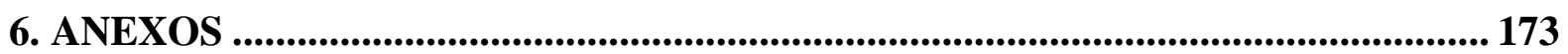

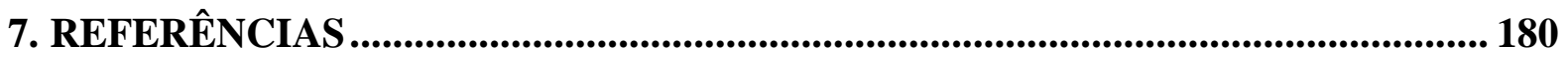




\section{INTRODUÇÃO}

Não há um Poder Legislativo no âmbito mundial. E não há uma constituição mundial. Há, contudo, uma notória, hipercomplexa, interferência de processos e representação legislativa que tem ganhado força e eficácia na incorporação de normas internacionais ao âmbito doméstico. A presente tese tem o objetivo de debater, explorar e estruturar os entrelaçamentos $^{1}$ de ordens legislativas extranacionais ${ }^{2}$ e nacionais, por meio dos conceitos de "processo legislativo" e "diplomacia parlamentar".

Esses dois vértices - processo legislativo e diplomacia parlamentar - dão consistência à análise ao Poder Legislativo, por serem a forma legislativa e representação democrática na atual configuração do direito internacional: fragmentado $^{3}$, descontínuo ${ }^{4}$ e heterárquico ${ }^{5} . \mathrm{Na}$

${ }^{1}$ A concepção de entrelaçamentos remete à ligação de estruturas, equivalentes funcionais e pontes de transição entre sistemas. O desenvolvimento do conceito envolve a compreensão de acoplamento estrutural, que, no caso entre o sistema jurídico e o político, é a constituição. Como critério de entrelaçamentos de ordens legislativas, a ideia de constituição é utilizada como condição binária em relações a avaliação de um entrelaçamento transconstitucional ou corrupto In: NEVES, Marcelo. Transconstitucionalismo. São Paulo: Martins Fontes, 2009. p. 31. Há uma série de exemplos sobre acoplamentos estruturais: a assessoria de especialistas na relação entre política e ciência. Universidade entre educação e ciência. Diplomas e certificados na relação entre economia. In: LUHMANN, Niklas. Derecho de la Sociedad. 2ª Ed. México: Universidad Iberoamericana; Herder. 2005.p. 540.

${ }^{2}$ Nomeamos, no âmbito da tese, toda ordem legislativa lato sensu internacional (no sentido de não nacional), como extranacional. Extra, prefixo de origem do latim: fora de, para fora de.

${ }^{3}$ Koskenniemi diferencia três formas de fragmentação: (i) a emergência de interpretações divergentes do direito, novas instituições frequentemente interpretam o direito de diferentes maneiras, procurando dar razão a novas preferências que prevalecem nessas instituições; (ii) a emergência de exceções institucionalizadas ao direito, a diferenciação funcional institucionalizou rígidas exceções ao direito, como, por exemplo, os tratados de direitos humanos são interpretados por organizações de direitos humanos diferentemente da maneira de que tratados regulares são interpretados com base na Convenção de Viena sobre Direito dos Tratados; (iii) o conflito de direitos particulares, essa terceira fragmentação opõe diferentes racionalidades umas às outras: comércio a meio ambiente, direitos humanos a direito humanitário. A fragmentação também é vista nos numerosos especialistas das áreas setoriais dos contextualizados regimes jurídicos internacionais, usando diferentes tipos de estratégias para produzir direito, fazer leis, favorecendo leis com diferentes resultados. In: KOSKENNIEMI,Martti, International Law-Making: Problems of Coherence and Fragmentation. ChathamHouseInternational Law. 2007.

4 A descontinuidade das normas leva a incoerências do sistema jurídico-político internacional. Descontinuidade no sentido de Delmas-Marty. De acordo com a autora, a descontinuidade das normas leva a incoerências do sistema jurídico-político internacional. Esta descontinuidade exclui a subordinação estreita 
perspectiva de uma sociedade hipercomplexa ${ }^{6} /$ policontextural $^{7}$, ambivalências tradicionais, como nacional/internacional, esquerda/direita, nacional/estrangeiro, tornam-se insuficientes para dar conta da intensa malha de ordens jurídico-políticas e da diversidade de temas e regimes internacionais que tencionam a literatura para um novo debate.

Esse novo debate retoma o tema da legitimidade ${ }^{8}$ e déficit democrático do direito internacional. A descontínua e fragmentada ordem internacional é resultado de ordens supranacionais e transnacionais emergentes, que proporcionam casos de processos e representação legislativa de natureza singular, como os casos do entrelaçamento de ordens supranacional/nacional da União Europeia/Estados-membros e da ordem transnacional /nacional no caso FIFA/Brasil, ambos explorados no presente trabalho.

O déficit democrático geralmente é associado ao debate sobre governança ${ }^{9}$. Essa noção compreende um governar por preferências e normas, regimes e práticas que não têm

entre diferentes conjuntos de regras, não significando que elas ganhem autonomia. In: DELMAS-MARTY, Mireille. Revista Penal. Estudios jurídicos comparados e internacionalizacióndelderecho. Publicado por Librairie Arthème Fayard 2003, Paris ; DELMAS-MARTY, Mireille; et al. Pour un nouvel imaginaire politique. Paris: Librairie Arthème Fayard, 2006.;__ Por um direito comum. Martins Fontes, 2004.

Sobre heterarquia da legislação internacional: "A hierarquia das fontes jurídicas é apenas uma tentativa inadequada de evitar que esta autorreferência originalmente dada por acumulações de metaníveis, sempre mais novos; mas o nível superior sempre colapsa em uma identidade com o nível mais baixo." In: TEUBNER, Gunther. "And God Laughed...” Indeterminacy, Self-reference, and Paradox In Law. Stanford Literature Review. N. 7. p. 19.

6 "Hipercomplexidade" pode ser definida como complexidade de segunda ordem, isto é, a complexidade da complexidade. A hipercomplexidade é uma categoria que pode explicar um número crescente de processos de observação e de comunicação nesta sociedade, quando se propõe a ver um problema jurídico de uma perspectiva econômica, assumindo que, na modernidade, esses sistemas adquiriram autonomia. In: QVORTRUP, Lars. The Hypercomplex Society. New York: Peter Lang Publishers, 2003. p. 16.; TEUBNER, Gunther. The King's Many Bodies: The Self-Deconctruction of Law's Hierarchy. Law and Society Review, Volume 31. Number4. 1997. p.763-787.

${ }^{7}$ A policontexturalidade é uma construção de operações em zonas periféricas em que um sistema consegue re-entrar em outro sistema, de forma a ter uma maior proximidade entre suas funções, sem prejuízo de suas estruturas e códigos. Quando dizemos que uma determinada forma de direito é policontextural, dizemos que ela se articula perifericamente no sentido de transformar estruturas e deciões em direito, que não seriam, via de regra, direito. Sobre lógica policontextural: GÜNTHER, Gotthard. Life as Poly-Contexturality. In: Beiträge zur Grundlegung einer operationsfähigen Dialektik, vol. 2. Hamburg: Meiner 1979, pp. 283306.; GOLDAMMER, Eberhar von. PAUL, Joachim. Gotthard Günther Annotations 2004/1. Vordender. Sommer-Eddition 2004. p. 02. Policontexturalidade no Direito: TEUBNER, Gunther. Global Bukowina: Legal Pluralism in the World Society. In: Gunther Teubner (ed.) Global Law Without a State. Dartmouth: Aldershot, 1996. p. 3-28.; LUZ, Cícero Krupp da. A policontexturalidade da lex mercatoria: contingência, paradoxo e decisão. Dissertação de Mestrado. 2009. $171 \mathrm{f}$.

${ }^{8}$ A legitimidade do Direito Internacional é tema de um dos últimos textos de Ronald Dworkin: "No entanto, a pergunta moderna - o que justifica o poder político coercitivo - não surge apenas de dentro de cada um dos Estados soberanos que são membros do sistema do westfaliano, mas também sobre o sistema em si, isto é, sobre a decisão de cada Estado em respeitar os princípios do sistema. (...) O argumento central que propus requer que uma doutrina de direito internacional seja interpretada a melhorar a legitimidade do sistema internacional." In: A New Philosophy for International Law. Philosophy \& Public Affairs, 41:2-30. 2013.

${ }^{9}$ Grande parte da literatura define "governança" de modo amplo o suficiente para abarcar todo tipo de nova experiência multinivelada, acabando por esvaziá-la: "a governança é a tentativa de um sistema de múltiplos níveis e formas de regulação no qual micro e macro regiões, assim como diferentes modalidades de associações, organizações e redes de cidadãos que emergem como novas unidades políticas possam contribuir para a reconstituição da política global em termos mais democráticos e socialmente menos 
centro localizável ou ethos. Constantemente compreende, também, um penetrar e redefinir a soberania dos Estados na disputa por espaços de ação no plano mundial ${ }^{10}$.

Assim, a governança está fortemente relacionada com os conceitos de diplomacia parlamentar e processo legislativo.Os entrelaçamentos legislativos devem ser analisados com os preceitos constitucionais de formas democráticas de processos, como garantia no procedimento adotado e acesso a representantes diretamente eleitos pela sociedade. A diplomacia parlamentar é a representação apta a projetar uma governança que desenvolva um papel fundamental de accountability ${ }^{11}$ (ou fiscalização democrática) e legitimidade. Portanto, o esclarecimento sobre a natureza desse fenômenotorna-se um novo ponto de debate para o desenvolvimento democrático de um processo político no plano mundial.

Essa dimensão na escala de poder abre espaço para a multiplicidade de atores que geram mudanças na forma da sociedade mundial, e tem-se a passagem de um sistema hierárquico para uma heterarquia, fruto da participação global de diferentes níveis dessas organizações: locais, nacionais, supranacionais e/ou transnacionais. Dá-se início, então, a um projeto horizontal de relações internacionais, por meio de novas esferas autônomas de autoridade. Se a resposta waltziana $^{12}$ enfatiza o caráter do Estado como ator incondicional, nos contextos da globalização e da governança global, tem sido sustentado o contrário: sua diluição entre outros atores, com importância cada vez maior na construção de uma heterarquia, em que o Estado é apenas um ator entre tantos, na busca de interesses próprios ou coletivos.

Esses casos são fontes primárias na busca de uma unidade jurídica internacional frente ao avanço entrópico de iniciativas e processos legislativos (supra/inter/trans) nacionais que moldam um sistema em que a sua síntese mais apurada se parece com um entrelaçamento constitucional instável. Desse modo, o primeiro objetivo da tese é problematizar o Poder Legislativo, em sua dimensão de representação e no seu processo legislativo, como um fenômeno original, num âmbito de intersecção entre o extranacional e o nacional.

excludentes." CAMARGO, Sonia de. Governança Global: utopia, desafio ou armadilha? In: Governança Global: Reorganização da política em todos os níveis de ação. Centro de Estudos Konrad-Adenauer-Stiftung. n. 16. São Paulo: 1999.p. 13

10 "Esqueça o status. Tudo o que conta é a existência do poder de fato, qualquer que seja sua origem ou objetivos. Só esse poder pode nos trazer algo sobre o bem comum de todos.” KOSKENNIEMI, Martti. What use for sovereignty today?Asian Journal of International Law. Vol.1. 2011. pp. 61-7.

${ }^{11}$ Não há tradução literal, mas refere-se à fiscalização democrática, responsabilidade pública de agentes, à prestação de conta, ou à transparência. Accountability, como conceito“implica que alguns atores tenham o direito de manter outros atores num quadro de regras, para julgar se eles cumpriram suas responsabilidades ou lhe impor sanções caso contrário.” In: KEOHANE, Robert; GRANT, Ruth. Accountability and Abuses of Power in World Politics. The American Political Science Review, vol. 99, n 1, February 2005, pp. 29-43.

${ }^{12}$ Em referência ao autor e referência neorrealista e estruturalista Kenneth Waltz. 
São raros os trabalhos de direito internacional que se propuseram o tema do poder legislativo. O único trabalho no meio acadêmico que utiliza a expressão literal "processo legislativo internacional" é de Szasz ${ }^{13}$. O autor descreve a discussão da época (1979) em torno das negociações de tratados multilaterais, em foros ad hoc, mas principalmente na Assembleia Geral das Nações Unidas, diferenciando etapas do processo legislativo da organização em iniciativa; formulação; adoção e pós-adoção.

Outros trabalhos em torno do tema detiveram-se, exclusivamente, em processos supranacionais/regionais, da União Europeia ${ }^{14}$ e do MERCOSUL ${ }^{15}$. Portanto, o trabalho se justifica por se debruçar sobre um tema pouco estudado e abordá-lo de umaperspectiva não convencional.

Ao contrário, no âmbito nacional, o Poder Legislativo de forma democrática é um dos principais elementos dentro de uma sociedade que se descreve como constitucional ${ }^{16}$, isto é, dentro de um Estado de Direito, no qual a constituição assume um papel de conservação dos direitos fundamentais e do controle de poder de uma ordem estabelecida como democrática ${ }^{17}$. Assim, no momento em que a sociedade torna-se moderna, e posteriormente constitucional, o poder de fazer leis para uma coletividade progressivamente exige uma contrapartida democrática, assumindo valores de representatividade e processo formal. Essa contrapartida é, precisamente, o evento constitucional. Portanto, no âmbito desta tese, Poder Legislativo consiste em toda relação em que esteja presente um processo legislativo e uma representação

13 SZASZ, Paul. Improving the International Legislative Process. Journal of International and Comparative Law. p.519, 1979.

${ }^{14}$ COSTA, Olivier; SAINT MARTIN, Florent; Le Parlament européen. La DocumentationFrançaise, Paris, 2009.; MEDEIROS, M. A. ; PAIVA, M. E. ; LAMENHA, Marion . Legitimidade, Representação e Tomada de Decisão: O Parlamento Europeu e o Parlasul em Perspectiva Comparada. Revista Brasileira de Política Internacional, v. 55, p. 154-173, 2012.

15 VENTURA, Deisy; PEROTTI, Alejandro D. El Proceso Legislativo der Merscosur. KONRADADENAUER-STIFTUNG E. V.: Montevideo, Uruguay, 2004.; DRI, Clarissa Franzoi. Building the Mercosur Parliament: integration on European patterns? Heidelberg Papers in South Asian and Comparative Politics, v. 59, p. 155-170, 2011. DRI, Clarissa Franzoi. Funcionalidade parlamentar nas experiências européia e andina: quais perspectivas para o Mercosul? Novos Estudos Jurídicos v. 14, p. 169-184, 2009.

${ }^{16} \mathrm{O}$ princípio democrático de Lincoln, governo do povo, pelo povo e para o povo, é constitucionalmente consagrado. Ele é mais do que um método ou técnica dos governantes escolherem os governados, pois, como princípio normativo, deve ser considerado nos seus vários aspectos políticos, econômicos, sociais e culturais, ele aspira tornar-se impulso dirigente de uma sociedade, contendo dimensões materiais e dimensões organizativo-procedimentais. In: CANOTILHO, J. J. Gomes. Direito Constitucional e teoria da constituição. Coimbra: Almedina, 2003. P. 288.

${ }^{17}$ Além dos direitos fundamentais, a constituição é uma resposta a questão organizacional da limitação e do controle interno e externo do poder, mediante participação dos governados nos procedimentos, especialmente nos de determinação da composição de órgão de governo - em conjunto com a especialização de funções. NEVES, Marcelo. Op. Cit. 2009. 
política legítima que resulte em norma para um ou mais territórios ${ }^{18}$, uma ou mais coletividades, sob um pressuposto constitucional.

O Poder Legislativo democrático é afirmado, para além de sua competência política de fazer lei, como uma necessidade representativa. Portanto, o Poder Legislativo será analisado sob dois vértices medulares: processo legislativo e representatividade.

Processo legislativo, nesta tese, é entendido como forma e ideologia ${ }^{19}$. Ao mesmo tempo em que é o iter seriado de atos para o fim legislativo, também é resíduo do paradigma racionalista, cujo objetivo de afastar-se da história e dos valores com uma forma positivista resulta num determinado conjunto sistemático de $\operatorname{conceitos}^{20}$. A inclusão ou não de atos e atores pode trazer resultados diversos. Por isso, explora-se a análise crítica das etapas do processo legislativo de cada ordem extranacional/nacional com objetivo de demonstrar os seus equivalentes funcionais nos entrelaçamentos das ordens ${ }^{21}$.

A representatividade será incorporada pela concepção de diplomacia parlamentar. A atual atribuição conceitual à diplomacia parlamentar abrange possibilidades de representação variadas e desorganizadas. Além de parlamentares nacionais que desempenham algum papel no exterior ${ }^{22}$ ou que tomam parte em assuntos extranacionais no Parlamento, a diplomacia parlamentar também inclui reuniões interparlamentares de parlamentos regionais e nacionais, parlamentos regionais que representam regiões, idiomas, coletividades, assembleias mundiais ad hoc ou foros mundiais ${ }^{23}$. O reconhecimento dessa situação gera uma série de efeitos de

18 Território como lócus de aplicação (extra)nacional, supranacional, nacional. A dependência da segmentação territorial é condição muito forte no sistema da política para se reproduzir. Diferentemente de outros sistemas, ciência, economia, técnica ou religião... Na política, após a diferenciação inicial - funcional - distinguindo de outras esferas de comunicação; a segunda diferenciação é segmentária, em sistemas políticos territoriais; a terceira diferenciação se dá na distinção entre Estado e organizações políticas do respectivo sistema territorial, conforme o esquema centro/periferia. In: NEVES, Marcelo. Op. Cit. 2009. p. 27.

${ }^{19}$ Em analogia à crítica ao Direito Processual Civil de Silva (2007) e em referência à teoria crítica das relações internacionais. Sobre o primeiro, o racionalismo pelo qual se resguarda o processo é próprio de uma estrutura moderna de pensamento pela qual o indivíduo, valendo-se apenas da razão, evita influência das ideologias, sendo hipoteticamente capaz de atingir as verdades absolutas. "É a ideologia da neutralidade quanto a valores com que se pretendeu construir o Estado Moderno." SILVA, Ovídio Araújo Baptista da. Processo e ideologia: o paradigma racionalista. Rio de Janeiro: Forense, 2004. p. 9.

${ }^{20}$ Procedimento legislativo é um complexo de atos, qualitativa e funcionalmente heterogêneos e autônomos, praticados por sujeitos diversos e dirigidos à produção de uma lei do Parlamento. Noutros termos: procedimento legislativo é a forma da função legislativa, isto é, o modo ou iter segundo o qual se opera a exteriorização do poder legislativo. In: CANOTILHO, J.J. Gomes. Direito Constitucional e teoria da constituição. Coimbra: Almedina, 2003. P. 871.

21 Equivalente funcional é um elemento chave na análise de entrelaçamentos de ordens. Embora não conceituado objetivamente em nenhuma obra de Niklas Luhmann ou Marcelo Neves, ele é reiteradamente utilizado como uma atribuição de função equivalente de um sistema (ou ordem) a outra. Esse conceito remete à ideia de acoplamento estrutural e racionalidade transversal de que nos ocupamos no próximo capítulo.

${ }^{22}$ RAY, R. Parliamentary Diplomacy. New Delhi: Chand. 1991, p. 20.

23 STAVRIDIS, Stelios. Parliamentary Diplomacy. Any Lessons for regional parliaments? 2007. Disponível em: <http://www. agora-parl. org/node/1288>Acesso em 12/10/2012. 
distanciamento e perplexidade com a ideia de diplomacia parlamentar. Contudo, nesta tese, por meio de uma sistematização da noção de diplomacia parlamentar, pretende-se demonstrar que a capacidade potencial da diplomacia parlamentar torna-se um ator multiangular dentro da perspectiva de entrelaçamentos das ordens legislativas extranacionais.

Esses dois aspectos têm o escopo de conferir legitimidade à presente proposta de análise de Poder Legislativo. A legitimidade ${ }^{24}$ é o aspecto que garante ao sistema político que processos legislativos tenham validade por meio de seu aspecto democrático e constitucional. Com efeito, a legitimidade torna-se, dentro da perspectiva do Estado de Direito Constitucional, uma necessidade democrática das fontes de direito.

Dentro da ótica do direito internacional público clássico, essa necessidade era tradicionalmente absorvida pelos postulados do artigo 38 do Estatuto da CorteInternacional de Justiça. $\mathrm{O}$ artigo enumera a série de fontes de direito internacional nas quais a Corte irá fundamentar sua decisão das controvérsias que lhe forem submetidas, mas também serve como cânone para descrever fontes ${ }^{25}$.Entretanto, diante da descontínua e fragmentada incorporação de novas formas das fontes de direito, observa-se vazios e desconexões entre os conceito de fontes do direito, legitimidade esoberania.

A soberania interna representa o monopólio da coerção legítima em certo território, como o próprio monopólio da criação da ordem jurídica, pois o Estado estabelece suas próprias competências. Mas admitir seu caráter absoluto seria equivalente a negar a existência do próprio direito internacional. ${ }^{26}$ Assim, o modelo de Estado soberano que ainda se sustenta como um sistema de autoridade política baseada no território, reconhecimento, autonomia e

\footnotetext{
${ }^{24}$ Pode-se definir legitimidade como uma disposição generalizada a aceitar decisões de conteúdo ainda não definido, dentro de certos limites de tolerância. Esse aceite consiste na troca da obediência contra uma participação democrática. A legitimidade do poder político não pode ceder a uma moral apresentada de forma natural, antes, tem de ser aprofundada no próprio sistema político. In: LUHMANN, Niklas. Legitimação pelo procedimento. Tradução de Maria da Conceição Corte-Real. Brasília, UnB, 1980. P. 145.

${ }^{25}$ O Estatuto foi redigido em 1920 com a intenção de servir a Corte Permanente de Justiça Internacional, e também foi anexado à Carta das Nações Unidas em 1945: as convenções internacionais, quer gerais, quer especiais, que estabeleçam regras expressamente reconhecidas pelos estados litigantes; o costume internacional, como prova de prática geral aceita como sendo o direito; os princípios gerais de direito reconhecidos pelas nações civilizadas; e, excepcionalmente, as decisões judiciais e a doutrina dos juristas mais qualificados das diferentes nações, como meio auxiliar para a determinação de regras de direito. In: SHAW, Malcolm. International Law. Cambridge: University Press, 2008.

${ }^{26}$ VENTURA, Deisy; SEITENFUS, Ricardo Antônio Silva. Introdução ao direito internacional público.

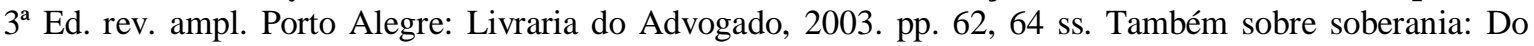
ponto de vista do direito internacional, um sentido negativo, diz-se, é a não-sujeição à determinação de outros centros normativos.(...) Absoluto no sentido de capacidade de determinar, no âmbito de sua atuação ao menos, a relevância e o caráter irrelevante de qualquer outro centro normativo que ali atue. (...) O modo como a teoria trata o poder na teoria da soberania faz com que o poder seja basicamente tratado como fonte do direito. In: FERRAZ JUNIOR, Tercio Sampaio. Estudos de Filosofia do Direito: reflexões sobre o poder, a liberdade, a justiça e o direito. $2^{\mathrm{a}}$ Ed. São Paulo: Atlas, 2003. P. 23.
} 
controle $^{27}$ é frequentemente ignorado ou violado na medida em que ordens de variados objetivos se sobrepõem ao direito internacional e nacional. "O que intriga a ciência jurídica tradicional é a pretensão dessas novas ordens jurídicas de se afirmarem impreterivelmente como ordens jurídicas que prescindem do Estado, que prevalecem contra os Estados, pondo em cheque a soberania." 28

Um dos objetivos do trabalho é destacar o Poder Legislativo no âmbito extranacional partindo de uma crítica às fontes do direito internacional. Essa crítica parte do problema associado à legitimidade das normas internacionais, deflagrado pela literatura como déficit democrático ${ }^{29}$. O déficit democrático da criação de normas internacionais torna-se, assim, o problema inicial da tese, cuja questão central consiste na falta de politização em sentido estrito ${ }^{30}$ da esfera internacional associada à sobreposição e incorporação crescente das normas internacionais ao âmbito doméstico.

Embora o problema já tenha sido posto recentemente, ele não está resolvido. Algumas organizações internacionais têm sido simpáticas à participação da sociedade civil e à criação de parlamentos, como a Organização Mundial do Comércio $^{31}$ e o MERCOSUL ${ }^{32}$, respectivamente.

\footnotetext{
${ }^{27}$ Territorialidade significa que autoridade política é exercida sobre um espaço geográfico definido, em vez de ser exercida, por exemplo, sobre pessoas. Reconhecimento mútuo significa que entidades territoriais juridicamente independentes se reconhecem em função da sua competência para celebrar acordos, normalmente tratados. Autonomia significa que nenhum ator externo goza de autoridade dentro das fronteiras do Estado. Controle significa que há uma expectativa não só de que os Estados soberanos têm a autoridade para agir, mas também de que eles podem efetivamente regular os movimentos nas suas fronteiras e dentro deles. In: KRASNER, Stephen D. Rethinking the sovereign state model. Review of International Studies Vol. 27, no. 05.2001. 17-42. p.18,19,41.

${ }_{28}^{28}$ NEVES, Op. Cit. P.252.

${ }^{29}$ O déficit democrático nas organizações internacionais pode ser visto como fenômeno da falta de legitimidade, de uma forma analítica, ou de uma forma normativa, como um dever crescente de organismos e redes internacionais terem maior nível democrático. Assim, o déficit democrático pode ser referido sob diferentes ângulos: falta de debate democrático de normas internacionais, o processo formal entre interno e externo para incorporação dessas normas e a relação entre legitimidade e formas de accountability. Literatura de déficit democrático: MORAVSCIK, Andrew. Is there a 'Democratic Deficit' in World Politics? A Framework for Analysis' Government and Opposition - An international Journal of Comparative Politics, vol. 39, n. 2 2004, p. 336-364.; KEOHANE, Robert; MACEDO, Stephen; MORAVSCIK, Andrew. Democracy-Enhancing Multilateralism. International Organization, vol. 63, no 1 , Winter 2009, pp. 1-31. DINGWERTH, Klaus; PATTBERG, Philipp.Global Governance as a Perspective in World Politics. Global Governance - a Review on Multilateralism and International Organizations, vol.12, no. 2, April-June 2006. P.185-203.

${ }^{30}$ Politização em sentido estrito se refere a um dos elementos do sistema político circular de Niklas Luhmann. Enquanto a política engloba uma circularidade de elementos, a política em sentido estrito se refere ao debate, negociação e convencimento na construção de decisões que vinculem uma coletividade. Esses conceitos são trabalhos no capítulo seguinte.

${ }^{31}$ SANCHEZ BADIN, M. R. .FOCOS: Fórum Contexto Internacional e Sociedade Civil - Edição I,II e III. Cadernos Direito GV, v. 12, p. 05-105, 2006. SANCHEZ BADIN, M. R. . Atores não-estatais e sua relação com a Organização Mundial do Comércio. In: Alberto do Amaral Junior. (Org.). Direito do Comércio Internacional. 1ed. São Paulo: Editora Juarez de Oliveira, 2002, v. 1, p. 151-170. SANCHEZ BADIN, M. R.
} 
Contudo, ainda permanecem ausentes elementos democráticos importantes de participação e representatividade, o que é denunciado como um déficit democrático, que produz reflexos negativos no contexto mundial, do ponto de vista da legitimidade democrática do direito internacional. Esta deficiência, decorrente de uma concepção tradicional de democracia, explica, com respaldo num conceito tradicional de soberania nacional, ${ }^{33}$ a dificuldade de reconhecimento dos entrelaçamentos de diferentes ordens e o debate e incorporação do direito internacional e o doméstico. "A legitimidade trata-se de um problema de reconhecimento, em última instância, das decisões do detentor de poder."34

O incremento no grau de complexidade do quadro de relações internacionais, com a multiplicação do número de protagonistas e procedimentos, aflora a questão crucial da pluralidade de ordenamentos jurídicos ${ }^{35}$. Contudo, essa pluralidade resulta numa questão institucional, de falta de processos políticos mais legítimos.

Por isso, o transconstitucionalismo ${ }^{36}$ é adotado como concepção teórica principal da

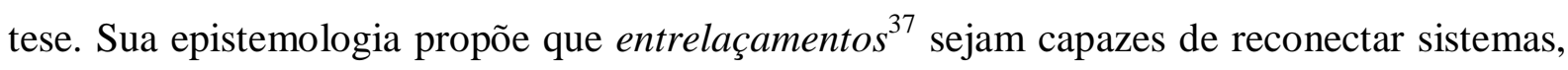
como o sistema jurídico, político e econômico, mas também entrelacem ordens no interior sistema funcional da sociedade mundial, como entre as nacionais e as extranacionais. $\mathrm{O}$ transconstitucionalismo se mostra mais apto para a passagem de uma situação de

Breves consideraciones sobre loslos mecanismos de participación de las ONGs en la OMC. Sur. Revista Internacional de Direitos Humanos. São Paulo, v. 4, n.3, p. 105-127, 2006.

${ }^{32}$ DRI, Clarissa Franzoi. La construction du Parlement du Mercosur: le poids des institutions, des intérêts et des idées. ÉtudesInternationales (Québec), v. XLIV, p. 177-196, 2013.; DRI, Clarissa Franzoi . Limits of the Institutional Mimesis of the European Union: The Case of the Mercosur Parliament. Latin American Policy, v. 1, p. 52-74, 2010.

${ }^{33}$ Conceito clássico de Bodin "A soberania é o poder absoluto (sem limitação de poder ou tempo) e perpétuo de uma república, tanto na relação aos particulares quanto em relação aos que manipulam todos os negócios de Estado de uma República.” In: BODIN, Jean. Les Six livres de la République: un abrégé du texte de l'édition de Paris de 1583. Ed. Gérard Mairet. Paris, Librairie générale française, 1993.

34 FERRAZ JUNIOR, Tercio Sampaio. Estudos de Filosofia do Direito: reflexões sobre o poder, a liberdade, a justiça e o direito. $2^{\mathrm{a}}$ Ed. São Paulo: Atlas, 2003. P.53.

${ }^{35}$ DALLARI, Pedro. Constituição e Relações Exteriores. São Paulo: Editora Saraiva, 1994. p.6

${ }^{36} \mathrm{O}$ transconstitucionalismo é o referencial teórico principal da tese, que tem como obra norteadora: NEVES, Marcelo da Costa Pinto. Transconstitucionalismo. São Paulo: Martins Fontes, 2009. A obra conta com influências da teoria dos sistemas, principalmente no que se refere a acoplamentos estruturais, de Niklas Luhmann, da razão transversal de Wolfang Welsch, que substancia limites e possibilidades da existência de racionalidades transversais parciais (como pontes de transição) tanto no sistema jurídico quanto em outros sistemas sociais. Por fim, notória influência de Anne-Marie Slaughter In: WELSCH, Wolfgang. Rationality and Reason Today.Scholarly Publications Cornell, 20003; LUHMANN, Niklas, El Derecho de La Sociedad.Tradução Javier Torres Nafarrate. México: Editorial Herder, 2005; SLAUGHTER, Anne-Marie. International Law in a World of Liberal States Vol. 6 European Journal of International Law 503-53. 1995.

${ }^{37}$ Este modelo de articulação redunda em um modelo de entrelaçamento transversal, no qual "as pontes de transição" de materiais entre ordens jurídicas ocorrem no nível constitucional. O intercâmbio e o aprendizado com o outro constituem o lado positivo desse entrelaçamento. Mas, precisamente porque não há mera convergência, há momentos de colisão que implicam a afirmação de uma identidade constitucional em detrimento da outra. Essa "dialética" do transconstitucionalismo implica uma forma de dois lados, sendo o valor positivo a interlocução construtiva entre ordens jurídicas. In: NEVES, Marcelo, 2009. Op. Cit.231. 
fragmentação desestruturada para uma diferenciação construtiva entre ordens do que métodos hierárquicos lineares e definitivos, sejam internacionais, estatais, supranacionais ou transnacionais.

$\mathrm{Na}$ tese, transpomos a pluralidade de ordens jurídicas para a pluralidade de ordens legislativas, propondo estender os entrelaçamentos do transconstitucionalismo, com ênfase nos aspectos democráticos, de participação política e de legitimidade. ${ }^{38}$ Nossa proposta é, pois, reconfigurar esse modelo para o plano político, mais precisamente para os mesmos níveis de ordens - agora legislativas - estabelecidos: internacional, supranacional e transnacional.

A tese se coaduna com essa teoria, que rejeita tanto o estatalismo quanto o internacionalismo, o supranacionalismo, o transnacionalismo ou o localismo como espaço de solução privilegiada dos problemas constitucionais. Ao contrário, deve-se indicar pontes de transição que resultem de entrelaçamentos, dentro de uma perspectiva da promoção de conversações constitucionais entre as diversas ordens jurídicas, estatais, internacionais, transnacionais, supranacionais ou locais.

Assim, diferentemente de aportes dogmáticos, e em consonância com a teoria crítica ${ }^{39}$, o transconstitucionalismo não tem o objetivo de tomar uma única ordem jurídica ou um tipo determinado de ordem como ponto de partida ou ultima ratio. É justamente o contrário. O transconstitucionalismo observa que toda ordem imposta ou única sempre leva de uma forma ou de outra ao imperialismo jurídico como violência. ${ }^{40}$ Assim, seu objetivo é justamente

\footnotetext{
${ }^{38}$ Na obra de referência, "Transconstitucionalismo", há um enfrentamento de um problema semelhante: o entrelaçamento múltiplo de ordens jurídicas constitucionais, mais precisamente no exame dos direitos humanos em cortes e tribunais de diferentes ordens jurídicas, na busca de equivalentes funcionais e acoplamentos estruturais que fornecessem respostas transconstitucionais ao problema. Entretanto, o entrelaçamento de ordens legislativas não foi abordado, sendo o tema da presente tese.

${ }^{39}$ A teoria crítica das relações internacionais tem como cerne criar um novo caminho de olhar sobre o horizonte das relações internacionais. Por isso, critica de maneira muito substantiva todas as teorias positivistas, inclusive a neoinstitucionalista. Retomando Habermas, por meio de uma esfera pública transnacional, e Robert Cox, com a reformulação das estruturas históricas, Linklater afirma que é possível criar uma ética universal do excluído. Linklater conta com os mesmos pressupostos das estruturas históricas, com grande influência de Cox e do novo Marxismo e tem como sua maior influência a escola de Frankfurt e, mais contemporaneamente, o pensamento de Habermas. Para ele, a teoria crítica não aceita - como quer propor o neorrealismo - a tese da imutabilidade, segundo a qual as comunidades políticas não podem escapar da lógica do poder inerente à condição de anarquia. Para Habermas, a noção de dominação e, talvez, repressão se esconde na técnica e na positivação formal do direito e da política. Apenas por meio de espaços públicos de fala, faz-se possível a plena participação política, o seio da formação de democracias. In: HABERMAS. J. Consciência Moral e Agir Comunicativo Rio de Janeiro: Tempo Universitário, 1989. p. 22. COX, Robert. "Social forces, states and world orders: beyond international relations Theory". In: KEOHANE, Robert. The neorealism and its critics. New York: Columbia, 1986. p.212. LINKLATER, A.. "The achivement of critical theory", In: International theory: positivism and beyond. S Smith; K. Booth; M. Zalewski. Cambridge: Cambridge University Press, 1996. p.282.

${ }^{40}$ Sobre a relação entre direito e violência: GROS, Frédéric. Estados de violência: ensaio sobre o fim da guerra. Aparecida / SP: Idéias\& Letras, 2010; LUHMANN, Niklas. A restituição do décimo segundo
} 
"afastar-se da tendência de sempre identificar a existência de uma nova Constituição quando surge uma ordem, instituição ou organização jurídica na sociedade contemporânea." ${ }^{41}$

Nesse sentido, o debate sobre a constitucionalização do direito internacional não deve ser uma mimetização da forma doméstica, não apenas pela falta de um poder constituinte no campo internacional, mas porque, mesmo que ele existisse, seria um império. E é precisamente o império o conceito que deve ser debatido se o direito internacional de fato pretende refletir alguns valores substantivos hierarquicamente ${ }^{42}$.

Assim, esse raciocínio associa-se com a teoria crítica. Diferentemente do neorrealismo ${ }^{43}$, a teoria crítica percebe o plano político como campo de lutas e não se intimida com a dualidade descritiva/normativa: ela entende que todas as teorias são normativas, ou seja, estão propondo e impondo - explicita ou implicitamente - um ponto de vista, e normalmente o ponto de vista tomado como verdadeiro nada mais é que o ponto de vista do vencedor. Embora por vezes falhe numa análise mais detalhada de instituições, nesse caso, o neoinstitucionalismo pode prover alguns conceitos sobre a democracia e grau de participação

camelo: do sentido de uma análise sociológica do direito. in: ARNAUD, André-Jean; LOPES Jr., Dalmir. Niklas Luhmann: Do Sistema Social à Sociologia Jurídica. Rio de Janeiro: Editora Lumen Juris, 2004.

${ }^{41}$ NEVES, M.. 2009. Op. cit.

${ }^{42}$ Noção de império de KOSKENNIEMI, Martti, 2008. Op. Cit.

${ }^{43}$ Autores realistas tinham a pretensão de construir uma teoria que fosse apta a lidar com a realidade, com fatos, não apenas de forma abstrata ou teórica. Essa teoria política era baseada na própria natureza humana. Sua maior crença é o racionalismo (radical) e no pressuposto de encontrar leis objetivas para a sociedade, da mesma forma que aconteceu em outras áreas das ciências humanas, como, por exemplo, no Direito com Hans Kelsen e a obra Teoria Pura do Direito, em que a norma jurídica está num perfeito edifício do direito onde não entram moral, valores e quaisquer outros conceitos alheios à metalinguagem do dever ser. Da mesma forma, Morgenthau montou uma carapuça para esconder-se de quaisquer preocupações morais, ideológicas ou culturais. Seu objetivo era claro: esclarecer como as relações de poder podem afetar o poder da nação. Essa refundação conta com um novo paradigma de sistema internacional a partir do estruturalismo. De modo geral, é possível afirmar que as correntes teóricas do realismo neoestruturalista e do neoinstitucionalismo se guardam em pressupostos racionais e estruturais, divergindo em outros pontos determinantes para suas conclusões, por vezes divergentes sobre efeitos na cooperação internacional. Nas relações internacionais, a noção realista estrutural é promovida pela obra de Waltz de 1979. Sua teoria irá concentrar-se na relação de grandes estruturas sistêmicas. Apenas as estruturas seriam capazes de gerar resultados explicativos verdadeiros, corretos. As outras teorias que se voltassem para os indivíduos ou nações como nível de análise seriam reducionistas. De modo análogo, mas com diferentes resultados, a teoria dos sistemas de Niklas Luhmann também compartilha de bases estrutural-funcionalistas, alicerce do pensamento do transconstitucionalismo de Marcelo Neves. Porém, na década de 1990, Mearsheimer apoia-se na Escola de Chicago para sustentar o contrário, dizendo que os grandes Estados são sempre revisionistas, são anti-status quo. In: MORGENTHAU, H. Política entre as nações. Brasília, UNB/Imprensa Oficial SP, 2003. ; Paulo: Martins Fontes, 1998. ; WALTZ, K. O Homem, o estado e a Guerra. São Paulo: Martins Fontes, 2004.; WALTZ, Kenneth(1979) Teoria das Relações Internacionais. Lisboa: Gradiva, 2002 MEARSHEIMER, John J. The tragedy of great power politics. New York/London: W.W Norton and Company, 2001. KELSEN, Hans. Teoria pura do direito. 6. ed. Traduzido por João Baptista Machado. São Paulo: Martins Fontes, 1998. LUHMANN, Niklas. La Sociedad de La Sociedad. Tradução Javier Torres Nafarrate. Cidade do México: Editorial Herder, 2007. 
de instituições. Portanto, na medida em que o trabalho se resguarda da teoria crítica, ele é permeável $^{44}$ pelo neoinstitucionalismo.

Em analogia com o transconstitucionalismo, para a análise dos entrelaçamentos, será utilizada uma formatação de ordens internacionais, supranacionais e transnacionais.

A ordem internacional stricto sensu - diferente do internacional lato sensu, de sentido extranacional -é caracterizada pela“"presença de representantes estatais legitimados por essa própria ordem. Toda conversação carrega em si o potencial de disputa. O problema é como solucionar essas disputas sem a imposição do top down na relação entre ordens." ${ }^{45}$ A ordem internacional stricto sensu é a relação em que apenas os entes estatais têm a palavra no debate. Isso pode englobar todo tipo de reunião de ministros de Estado das relações exteriores, chefes de Estado ou diplomatas estatais.

A teoria neorrealista explicaria essa ordem como a única ordem existente, e os Estados como atores primeiros e últimos em qualquer ato internacional, pois as instituições estariam apenas a serviço deles. Portanto, o Poder Legislativo dessa ordem estaria monopolizado e centralizado pelos Estados. Os processos legislativos ficam restritos à soberania, enquanto a diplomacia parlamentar se restringe à função e atuação parlamentar de diplomatas estatais.

A ordem supranacional, por sua vez, está ligada à projeção de blocos regionais. Atualmente, as uniões regionais têm natureza e escopo variados, embora se possa dizer que a maioria se espelhou na experiência europeia, única em robustez e desempenho de funções. Assim, a ideia de ordem regional tem na União Europeia o único arquétipo supranacional válido. A ordem supranacional teria como características: a) autonomia de um conjunto de regras diferenciado dos ordenamentos nacionais, situado acima deles em certos domínios (graças ao princípio da primazia da regra comunitária), para proteger o interesse coletivo, das suscetibilidades políticas ou dos interesses nacionais contrários; b) a origem de tais regras, contratual via fonte primária, mas de natureza peculiar, por força de fontes secundárias; c) e sua incorporação direta às ordens jurídicas nacionais, isto é, a aplicabilidade imediata das regras de direito comunitário ${ }^{46}$.

Em virtude de seu singular Poder Legislativo de normas autoaplicáveis (primazia da regra comunitária), a União Europeia configura-se como um caso único de equivalente

\footnotetext{
${ }^{44}$ Sobre a noção de permeável: a permeabilidade entre marcos regulatórios acarreta justamente a impossibilidade, quase generalizada, de identificar de modo estanque o que seja uma regulação nacional ou internacional. In: VENTURA, D. F. L. ; MIOLA, I. Z. Os efeitos da transnacionalização sobre a governança regional: o caso da conflituosa implantação da indústria de celulose no Cone Sul da América. Contexto Internacional PUCRJ. Impresso., v. 31, p. 391-427. 2009. p. 394.

${ }^{45}$ NEVES, Marcelo. Transconstitucionalismo. São Paulo: Martins Fontes, 2009. p. 103.

${ }^{46}$ VENTURA, Deisy; SEITENFUS, Ricardo Antônio Silva. Introdução ao direito internacional público.

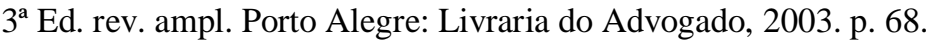


funcional no qual o entrelaçamento legislativo de ordens ocorre constitucionalmente e institucionalmente, do nível extranacional ao nacional. Com efeito, cria-se um déficit democrático e a subsequente necessidade de empoderamento do Parlamento Europeu na evolução de sua estrutura institucional, e democratização de suas estruturas, responsáveis por entrelaçar ordens normativas. Por isso, os entrelaçamentos das ordens político-legislativas da União e dos Estados-membros será um dos casos discutidos.

As ordens transnacionais em sentido estrito envolvem atores privados ou quasepúblicos que contam com pouco ou nenhum processo democrático. Embora essas ordens tenham sedes físicas, sua característica fundante é a transterritorialidade global dentro de um tema: comércio, internet ou esporte. Elas têm êxito nos seus objetivos por atuarem de forma estratégica mediante soft law ${ }^{47}$. "As ordens jurídicas transnacionais instrumentalizadas pelas grandes empresas atuam destrutivamente sobre as formas de direito dos chamados países em desenvolvimento e das comunidades locais não estatais." 48 Essas ordens envolvem particularidades contraditórias de naturezas distintas: ao mesmo tempo que contam com alto déficit democrático na elaboração de regras, têm uma força soft poderosa na incorporação em ordens nacionais. Por isso, um dos casos explorados será a relação da ordem transnacional do esporte do futebol e o governo do Brasil, no caso FIFA-Brasil, a propósito da elaboração da legislação para a Copa do Mundo de 2014.

Assim, a problemática da tese parte de dois problemas-chaves da dogmática tradicional: o problema de um processo legislativo que acontece fora (extra) do nacional e o problema de uma diplomacia parlamentar sem poderes legislativos. As duas variáveis que pretendem dar respostas a esses problemas encontram abrigo em interpretações teóricas e explorações fáticas de que, por um lado, o processo legislativo extranacional cruza e entrelaça ordens jurídico-políticas por meio de procedimentos formais e, por outro, a diplomacia parlamentar é um conceito amplo, que engloba, entre determinados atores e diferentes atuações, uma diplomacia parlamentar eleita com função legislativa.

\footnotetext{
${ }^{47} \mathrm{O}$ conceito de soft law pode ser entendido como um conjunto de "regras cujo valor normativo seria limitado, seja porque os instrumentos que as contêm não seriam juridicamente obrigatórios, seja porque as disposições em causa, ainda que figurando em um instrumento constringente, não criariam obrigações de direito positivo ou não criariam senão obrigações pouco constringentes. In: NASSER, Salem Hikmat. Fontes e Normas do Direito Internacional: Um estudo sobre a SOFT LAW. São Paulo: Editora Atlas, 2005. p. 25. Outro conceito: Soft law refere-se a normas internacionais que são deliberadamente de caráter não vinculativo, mas ainda têm relevância jurídica, localizando-se no crepúsculo entre direito e política. Importantes são exemplos de organizações internacionais e resoluções internacionais planos de ação ou códigos de conduta. In: SKJÆRSETH, Jon Birger.;STOKKE, Olav Schram; WETTESTAD, Jørgen. Soft Law, Hard Law, and Effective Implementation of International Environmental Norms. Global Environmental Politics6:3, August 2006. p. 104.

${ }^{48}$ NEVES, M. Op. Cit. p. 106.
} 
Dessa forma, o problema de pesquisa que se constitui é: sob quais estruturas institucionais, equivalentes funcionais e diplomacia parlamentar é possível perceber um Poder Legislativo no âmbito extranacional, sob a perspectiva transconstitucional, que afete o sistema jurídico nacional?

O objetivo central da tese é explorar e demonstrar o entrelaçamento de ordens legislativas considerando as ordens legislativas nacionais, supranacionais e transnacionais, descrevendo as formas de interferência legislativa por processo legislativo que contenha diferentes níveis de ordens ou por uma participação parlamentar em assuntos de interesse internacional, supranacional ou transnacional.

A hipótese do trabalho é que para haver um entrelaçamento transconstitucional são necessárias duas condições: um processo legislativo constitucional e participação da diplomacia parlamentar eleita com função legislativa. Todo processo legislativo, por definição, é constitucional. No sentido de controle democrático de poder, diferente da simples positivação dogmático do termo (in) constitucional ${ }^{49}$. E a diplomacia parlamentar com função legislativo pressupõe que haja uma oportunidade de contraditório e de oposição na incorporação ou produção do entrelaçamento legislativo.

Assim, sempre que houver um entrelaçamento constitucional de ordens legislativas de diferentes níveis - estatal, internacional, supranacional e transnacional - com participação democrática da diplomacia parlamentar, confirmaremos o caso de transconstitucionalismo, ou, no caso contrário, uma corrupção sistêmica.

Um entrelaçamento por meio de um acoplamento estrutural forte entre política e direito sempre se dá por meio da constituição (transconstitucionalismo) ou, se for fraco, uma legislação. Para esse diagnóstico, irá se observar a diferenciação rigorosa entre sistemas e processos político-jurídicos. Ao contrário, todos os casos em que há interferência que se sobrepõe de um sistema a outro por seu código, haverá uma corrupção sistêmica.

Embora, a conotação comum de corrupção tenha uma semântica política redundante e imprecisa, o conceito é utilizado na teoria dos sistemas para designar toda ruptura que ocorre por meios que corrompam o sistema: mais grave, por operações ou atos legislativos que se utilizam de um outro sistema em se passando por ele. A corrupção sistêmica é a figura de um ator que representa ser o que não é para obter uma outra função.

A corrupção sistêmica é a face negativa dos acoplamentos estruturais. Ocorre quando houver incapacidade do sistema de reagir, conforme seus

${ }^{49}$ CANOTILHO, J. J. Gomes. 2003. Op. Cit. P. 288. 
próprios critérios e programas à sobreposição de um outro código, como, de forma comum, se observa entre o sistema da economia (ter - não ter) sobre o código político de oposição, governo, ou código do direito, de lícito e ilícito ${ }^{50}$.

Assim, os entrelaçamentos de ordens poderão ser observados de duas maneiras opostas, transconstitucionais ou corruptas. Daí se entender, para desenvolver a hipótese supra definida, que os casos selecionados serão indicativos com resultados para ambos lados. No caso do entrelaçamento supranacional/nacional da União Europeia e Estados-membros, serão explorado os contatos e entrelaçamentos transconstitucionais no caso da Diretiva de Retorno 115/2008, aprovada em 2009. Enquanto, no entrelaçamento transnacional/nacional, será desenhada a corrupção sistêmica da relação FIFA-Brasil.

Não é objetivo da tese estudar o que se tem chamado de política externa e legislativo. Há estudos com esse enfoque específico, inclusive com linhas de pesquisa e programas de pós-graduação, com formas quantitativas e qualitativas em relações internacionais que se dedicam exclusivamente a esse tema ${ }^{51}$. Esse enfoque, por vezes, enfatiza o papel das eleições, partidos e forças políticas ideológicas que atuam no legislativo.

Também não é objetivo da tese discutir democracia nas organizações internacionais ${ }^{52}$. Há uma vasta literatura neoinstitucionalista que faz essa leitura, por exemplo, privilegiando grupos organizados da sociedade civil $^{53}$. Contudo, há algumas noções sobre déficit democrático e governança que são utilizadas como referência acessória, por emprestar noções que envolvem a relação entre democracia, constituição e processo legislativo. Não constam nos objetivos delinear ou propor um inexistente processo legislativo internacional ou

\footnotetext{
${ }^{50}$ NEVES, Marcelo. Transconstitucionalismo. São Paulo: Martins Fontes, 2009. p. 37.

${ }^{51}$ Referências: OLIVEIRA, A. J. S. N. ; ONUKI, Janina. Política comercial e Legislativo: a atuação do empresariado brasileiro. In: MANCUSO, Wagner Pralon; LEOPOLDI, Maria Antonieta; IGLECIAS, Wagner. (Org.). Estado, empresariado e desenvolvimento no Brasil: novas teorias, novas trajetórias. 1 ed. São Paulo: Editora da Cultura, 2010, v. 1, p. 1-23. FIGUEIREDO, A.C. \& LIMONGI, F.. Executivo e Legislativo na nova ordem constitucional. Rio de Janeiro, FGV.1999.; CELLI JUNIOR, U. A Constituição, o Parlamento e a política externa brasileira. Publicado em Correio Internacional. 2003.

${ }^{52}$ Referências: KOSKENNIEMI, M. International Law-Making: problems of coherence and fragmentation. A summary of the Chatham House International Law discussion group meetingheld on 23 March 2007; BOYLE, Alan E. CHINKIN, C. M. The making of international law. Oxford University Press, 2007. P. 338.

${ }^{53}$ Sobre participação e sociedade civil: SANCHEZ BADIN, M. R. FOCOS: Fórum Contexto Internacional e Sociedade Civil - Edição I,II e III. Cadernos Direito GV, v. 12, p. 05-105, 2006. SANCHEZ BADIN, M. R. Atores não-estatais e sua relação com a Organização Mundial do Comércio. In: Alberto do Amaral Junior. (Org.). Direito do Comércio Internacional. 1ed. São Paulo: Editora Juarez de Oliveira, 2002, v. 1, p. 151170. SANCHEZ BADIN, M. R. Breves consideraciones sobre los mecanismos de participación de las ONGs en la OMC. Sur. Revista Internacional de Direitos Humanos, São Paulo, v. 4, n.3, p. 105-127, 2006.; ZURN, Michael. Global Governance and Legitimacy Problems. Government and Opposition- An International Journal of Comparative Politics, vol. 39, no. 4, 2004.; NANZ, Patricia; STEFFEK, Jens. Global Governance, Participation and the Public Sphere.Government and Opposition - An International Journal of Comparative Politics, vol. 39, no. 4, 2004.
} 
parlamento internacional. Embora a tese seja também propositiva, seus limites são claros: verificar os possíveis entrelaçamentos de ordens legislativas que ocorrem dentro de ordens constitucionais que tenham como atores a figura da diplomacia parlamentar eleita com função legislativa.

A temática envolve, portanto, explorar o atual estado da arte democrático de espaços internacionais desenvolvidos por outras representatividade sem seus processos legislativos, como a diplomacia parlamentar.

Ao contrário do que se dá com o princípio democrático, de viés constitucional, a produção legislativa extranacional é vista preliminarmente com um reduzido debate público, um processo plural minguado, limitando as motivações democráticas de diferentes atores. De acordo com essa visão, essa ordem não teria capacidade de assegurar importantes "postulados da teoria democrática representativa, como órgãos representativos, eleições periódicas, pluralismo partidário, separação de poderes, que implicaria numa democracia participativa, isto é, estruturação de processos que ofereçam aos cidadãos exercer o controle crítico na divergência de opiniões, produzir inputs políticos democráticos."

A ideia de representação ligada historicamente à separação de poderes, e, como tal, à organização constitucional estabelecida em decorrência dos movimentos revolucionários liberais, precisa ser revista com seriedade. Mesmo no âmbito nacional, essa relação não é equilibrada. Essa deficiência do sistema é uma incoerência que afeta precisamente a separação dos poderes. Falta criatividade para reunir o conjunto de atores, públicas, sociais e econômico sem um novo triângulo cívico ${ }^{55}$.

No plano mundial a situação é ainda mais disforme, por envolver, atualmente, a preeminência de instituições com aspecto de Poder Executivo, incertezas sobre a existência de um Poder Judiciário e fraquezas de um Poder Legislativo quase ausente ${ }^{56}$. Tal enunciado justifica largamente o estudo das relações emergentes no contexto internacional de criação de normas, já que a atuação do Poder Legislativo e, particularmente, das assembleias supranacionais de parlamentares, como no caso do Parlamento do MERCOSUL e do Parlamento Europeu, não tem merecido a devida atenção no campo das relações internacionais.

\footnotetext{
${ }^{54}$ CANOTILHO, J.J. Gomes. Direito Constitucional e teoria da constituição. Coimbra: Almedina, 2003. P. 288.

${ }^{55}$ DELMAS-MARTY, Mireille. Revista Penal. Estudios jurídicos comparados e internacionalización Del derecho. Publicado por Librairie Arthème Fayard 2003, Paris.

${ }^{56}$ DELMAS-MARTY, Mireille. Três Desafios para um Direito Mundial. Tradução Fauzi Hassan Choukr. Rio de Janeiro: Editora Lumen Juris, 2003. p. 170.
} 
A sociedade civil $^{57}$, formada tanto por organizações não governamentais e movimentos sociais quanto por corporações internacionais ou interesses particulares, forja um sistema de representação em nível mundial que encerra duas dúvidas: sua legitimidade e accountability. No que se refere à legitimidade, a sociedade civil desenvolve uma representação de interesses de coletividades, uma vez que grande parte das organizações internacionais não contam com parlamentos legislativos de qualquer ordem. Em compensação, não importa o tamanho dos esforços da sociedade civil, a accountability só produz resultados com a intervenção de parlamentos, do judiciário, avaliações de especialistas e da mídia ${ }^{58}$.

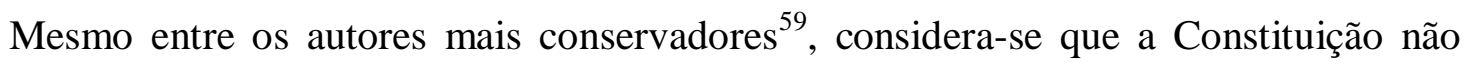
pode ser corretamente compreendida sem que se pondere o valor e o significado da representação. A representação democrática é um dos fatores importantes que permitem observar e avaliar níveis democráticos dentro de um Estado, Organização ou Instituição.

Nesse contexto, o entrelaçamento de ordens legislativas engloba uma rede de ordens estatais, supranacionais, transnacionais e internacionais que interagem de forma mais ou menos democrática, de acordo com seu desenho institucional e atuação de seus agentes. Os dois casos explorados serão analisados com as noções introduzidas que contenham os critérios previamente estabelecidos: processos legislativos entrelaçados e diplomacia parlamentar com função legislativa. Como método, utiliza-se uma revisão teórica com exploração de estudos de caso. Serão utilizadas fontes primárias de pesquisa, como documentos, legislações, assim como fontes secundárias de cunho bibliográfico.

A estrutura do trabalho será composta por três capítulos: o primeiro consta de revisão bibliográfica e construção teórica da proposta de análise do processo legislativo e diplomacia parlamentar. O segundo e terceiro assumem a forma de exploração de estudos de caso dos entrelaçamentos de ordens: supranacional-estatal, no caso da Diretiva de Retorno da União Europeia/Estados-membros; transnacional-estatal, no caso FIFA/Brasil.

A primeira parte será desenhada com os contornos das observações já realizadas sobre o posicionamento do transconstitucionalismo dentro das relações internacionais, a referida teoria crítica, com foco na estrutura do Poder Legislativo: primeiro conceituando e associando

\footnotetext{
${ }^{57}$ Definição de sociedade civil como "um espaço político onde associações voluntárias buscam, fora de partidos políticos, moldar as regras que governam um ou outro aspecto da vida social". In: SCHOLTE, Jan Aart. Civil Society and Democratically Accountable Global Governance. Government and Opposition - An International Journal of Comparative Politics, vol. 39, no. 4, 2004.

${ }^{58}$ SCHOLTE, Jan Aart. "Civil Society and Democratically Accountable Global Governance". Government and Opposition - An International Journal of Comparative Politics, vol. 39, no. 4, 2004.p. 233.

${ }^{59}$ FERREIRA FILHO, Manoel Gonçalves, Do Processo Legislativo. $4^{a}$ Edição. São Paulo: Editora Saraiva, 2001. p.63.
} 
a crítica do processo legislativo e fontes do direito às etapas do processo; depois revendo a literatura de diplomacia parlamentar, no intuito de defini-la e sistematizá-la. A diplomacia parlamentar será dimensionada em suas espécies variadas, verificando em que medida é possível que ela diminua o déficit democrático dos processos de ordens extranacionais, uma vez que seu conceito é demasiadamente amplo. Por exemplo, pode-se entender que diplomacia parlamentar pode significar que os parlamentares desempenham o papel de diplomatas, ou que as Assembleias Parlamentares possam intervir ativamente na formulação da política externa ${ }^{60}$. Mas também se pode entender a atuação de parlamentares eleitos em órgãos transnacionais e regionais, uma vez que "há uma proliferação de órgãos parlamentares nacionais e transnacionais com um ativo papel nas questões internacionais. Esse importante fenômeno representa uma forma emergente de diplomacia pública, chamada de diplomacia parlamentar". 61

Assim, um dos objetivos desta tese é revisar a literatura sobre o tema, sintetizar e organizar o conceito de diplomacia parlamentar, sistematizando-o em dois níveis: democrático e funcional. A primeira diferença é precisamente a democrática, e, em consonância com o transconstitucionalismo, utilizamos o critério eleito/não-eleito para distinguir dois tipos de diplomacia parlamentar. O segundo nível está associado aos poderes e funções classicamente ligados ao legislativo: a função legislativa, que diferencia todos aqueles que no seu lócus se ocupam do processo legislativo, isto é, de fazer leis; a função fiscalizadora, marca democrática associada ao critério da oposição no sentido de Luhmann; e, por último, algo próprio da diplomacia parlamentar, a função diplomática, que englobará uma série de atividades e características próprias desses atores.

As três funções serão descritas e exploradas com exemplos e autores, mas o foco do trabalho será a diplomacia parlamentar eleita com função legislativa. Essa escolha se justifica porque a União Europeia é o exemplo radical de relação de supranacionalidade e nacionalidade, enquanto a Lei Geral da Copa e a relação transnacional/nacional são exemplo vivo e de extrema importância para o Brasil.

A primazia do direito comunitário e a repaginada estrutura institucional da União Europeia a partir de Tratado de Lisboa registram uma nova faceta de entrelaçamentos, incluindo maior participação dos parlamentos nacionais. Contudo, ainda contam algumas dificuldades de efetividade e incorporação dentro do seu aspecto institucional. Para visualização do entrelaçamento das ordens legislativas supranacional e nacional será analisada

\footnotetext{
${ }^{60}$ RAY, R. Parliamentary Diplomacy. New Delhi: Chand. 1991, p. 2.

${ }^{61}$ STAVRIDIS, Stelios. Parliamentary Diplomacy. Any Lessons for regional parliaments? p. 3.
} 
a aprovação da Diretiva de Retorno 115/2008 ${ }^{62}$. Esta diretiva, que constitui uma primeira etapa rumo a uma política de imigração europeia, visa a promover o regresso voluntário de imigrantes ilegais, bem como estabelecer normas mínimas no que diz respeito ao período de detenção e à interdição de entrada na UE e garantias processuais. ${ }^{63}$ A visualização rigorosa das etapas desse processo legislativo vinculado à diplomacia parlamentar eleita parece ser uma condição para que se possa observar o entrelaçamento das ordens legislativas e o aumento ou diminuição do déficit democrático dessa relação.

A discussão democrática da União Europeia é muito particular por suas preocupações, contradições e paradoxos. Por esse motivo, ela pode parecer ainda mais interessante por fornecer elementos da formação de uma conjuntura que se mostra, ao mesmo tempo, desejada e criticada; inclusiva e exclusiva; democrática e autoritária; forte e fraca. A diplomacia parlamentar assume um papel determinante no processo legislativo da ordem legislativa supranacional. A partir desses atores, abre-se toda uma nova gama de considerações: novos partidos, interesses e coalizões.

A escolha do caso estatal/transnacional justifica-se na medida em que a Copa do Mundo de 2014 é um evento eminente, de grandes proporções e, especialmente, envolve elementos de natureza legislativa diversa, distinguindo-se de um simples processo de incorporação de tratados internacionais. Com esse caso, abre-se espaço para discussão do tamanho da atual força política e do papel dos parlamentos nacionais na aprovação de atos internacionais negociados e firmados pelo Poder Executivo, em geral vinculada à aprovação $a$ posteriori.

Justamente, a partir desse aspecto clássico, evidencia-se o despreparo das instituições nacionais em vista da ordem jurídica transnacional, com fortes características privadas, autônomas da soberania estatal, difusas em relação ao território, mas com perspicácia e força legislativa no relacionamento com o Poder Legislativo nacional. Essa força tem uma equivalência funcional, dentre os entrelaçamentos de ordens legislativas, com um aspecto diferenciado de corrupção sistêmica, tamanha a força de certas ordens transnacionais dentro de Estados soberanos. Daí a escolha da análise da relação entre FIFA e Brasil no estabelecimento das Competições da Copa do Mundo de 2014 e Copa das Confederações de 2013.

\footnotetext{
${ }^{62}$ Diretiva Número 2008/115/CE do Parlamento Europeu e do Conselho, oficialmente publicada em 16 de Dezembro de 2008, relativa a normas e procedimentos comuns nos Estados-membros para o regresso de nacionais de outros países em situação irregular. In: PARLAMENTO EUROPEU.

${ }^{63}$ PARLAMENTO EUROPEU. Comunicado de Imprensa: Parlamento Europeu aprova directiva de retorno. Disponível em: <http://www.europarl.europa.eu/news/expert/infopress_page/018-31787-168-06-25902-20080616IPR31785-16-06-2008-2008-true/default_pt.htm> Acesso em 06.07.09
} 
Por fim, a ideia que envolve o trabalho como um todo é que a pluralidade de ordens jurídicas remete, da perspectiva do transconstitucionalismo e da teoria crítica, à relação complementar entre identidade e alteridade.

A alteridade é um conceito horizontalmente construído com a democracia, isto é, o pressuposto democrático é um de seus axiomas. Isso quadra com a ideia de participação ampla e democrática da diplomacia parlamentar dentro dos processos legislativos extranacionais. Assim, parte-se da noção de que a representação e o parlamento podem ser lugares onde se enxergam outros pontos de vista, onde minorias ou maiorias podem expressar seu lugar na política externa.

Com efeito, o método do transconstitucionalismo "não pode ter ponto de partida definido de uma ordem jurídica, muito menos daquela dos mais poderosos. ${ }^{\text {64 }}$ Dessa perspectiva, é possível o desenvolvimento de uma racionalidade transversal não somente entre ordens jurídicas, mas também entre ordens legislativas. Mas, para isso, é necessária uma articulação recíproca de regras e princípios ante ao caso.

O Estado deixa de ser o lócus exclusivo de decisões de problemas constitucionais. Continua como um lugar privilegiado, mas um dentre tantos outros. A própria identidade de cada observador define o seu ponto cego, o observador não pode ver em virtude de sua posição ou perspectiva de posição. Eu vejo aquilo que tu não vês, e o contrário, o ponto cego de um observador pode ser visto pelo outro. Nesse sentido, pode-se afirmar que o transconstitucionalismo implica o reconhecimento dos limites de observação de uma determinada ordem, que admite a alternativa: o ponto cego, que o outro pode ver ${ }^{65}$.

Dessa maneira, o transconstitucionalismo depende de um método que não se concentre em uma identidade cega. Ordens jurídicas - ou políticas - isoladas são levadas, normalmente, a considerar em primeiro plano a sua identidade, pois, caso contrário, diluem-se como ordens indiferenciadas de seu ambiente ${ }^{66}$.

Só em um modelo de alteridade que se construa exatamente em torno da busca de uma permanente possibilidade de alteração da identidade em face do outro, pode-se processar o paradoxo da colisão entre direitos fundamentais. Ao ser reprimido ou sublimado por uma instância de otimização, esse paradoxo tende a retornar, em outro momento, de forma bloqueante ou destrutiva ${ }^{67}$.

\footnotetext{
${ }^{64}$ NEVES, Marcelo. Transconstitucionalismo. São Paulo: Martins Fontes, 2009. p. 245.

${ }^{65}$ NEVES, Marcelo. Transconstitucionalismo. São Paulo: Martins Fontes, 2009. p. 243

${ }^{66}$ NEVES, Marcelo. Transconstitucionalismo. São Paulo: Martins Fontes, 2009. p. 243.

${ }^{67}$ NEVES, Marcelo. Transconstitucionalismo. São Paulo: Martins Fontes, 2009. p. 244.
} 
Ao replicar esse raciocínio, buscamos compreender os sintomas que a sociedade apresenta, seus sintomas representam suas necessidades. É preciso criar um novo diagnóstico, com novas perguntas, novos métodos. Especialmente, os conceitos que fundam o transconstitucionalismo como acoplamento estrutural e a alteridade-dupla contingência são correlatos de um forte argumento que se associa à ética universal do excluído da teoria crítica. 


\section{PODER LEGISLATIVO EXTRANACIONAL: PROCESSO LEGISLATIVO E DIPLOMACIA PARLAMENTAR}

Os espaços internacionais lato sensu de debate não são um fenômeno recente. A novidade está no seu crescente protagonismo dentro da conjuntura mundial. O Poder Legislativo extranacional passa por um momento de eventos não lineares: parlamentos extranacionais de variadas ordens com diferentes poderes; eventos mundiais com participação de diplomacia parlamentar sobre regimes diferentes, com resultados distintos; ordens transnacionais com pouca participação e muito poder; e, por fim, a tradicional separação de poderes e incorporação de normas internacionais. Esse diagnóstico será desenvolvido e ampliado neste capítulo.

As noções de representação e de processo legislativo são os dois pilares de todo Poder Legislativo. Na representação está a necessidade de participação e legitimidade da função de fazer leis para uma coletividade. Essa representação precisa ter limites e possibilidades claros dentro de uma institucionalidade, isto é, dentro de uma ideia de processo legislativo igual e claro para todos. "O poder legislativo é o órgão coletivo (ou conjunto de órgãos coletivos) composto de membros eleitos pelo povo (em princípio) destinado a exercer a função de legislar, além de outras." 68

Não se compreende por poder legislativo a função de criar lei, mas um aspecto especial dessa função, a criação de normas gerais. "Uma lei" - um produto do processo legislativo é essencialmente uma normal geral ou um complexo de tais normas. Uma vez que há normas jurídicas individuais, como as sentenças ${ }^{69}$.

${ }^{68}$ SILVA, José Afonso da, 2006. Op. Cit. p. 57

${ }^{69}$ KELSEN, Hans. Teoria Geral do Direito e do Estado. $3^{\text {a }}$ Ed. São Paulo: Martins Fontes, 1998. P. 387. 
O Poder Legislativo extranacional, por sua vez, relaciona-se com entrelaçamentos de ordens e com a atuação da diplomacia parlamentar. Contudo, as relações entre ordens diferentes (internacional, supranacional ou transnacional) ainda orbitam, necessariamente, ao redor do Estado, numa revisão contínua da noção de soberania e separação de poderes.

A concessão de soberania e aumento de participação é um assunto litigioso. As aberturas democráticas das organizações internacionais pela maior diplomacia parlamentar têm sido morosas ou dificultadas. Assim se dá, por exemplo, com o arquivado Projeto de Lei n. ${ }^{\circ}$ 5.974/1982, que propunha a obrigatoriedade de participação de representantes parlamentares oposicionistas em missão oficial brasileira no exterior, de autoria do deputado José Frejat; ou com o Projeto de Emenda à Constituição 52/2001, também já arquivado, do Senador Roberto Requião do (PMDB-PR), que propôs aumento da participação do Congresso Nacional nas tratativas de comércio internacional ${ }^{70}$.

Desde a diferenciação funcional entre Estado e política, as fontes não nascem por intuição divina, monárquica ou natural ${ }^{71}$. O Estado de Direito democrático cria e promulga normas por meio de processos, que devem ser públicos, claramente definidos e preocupados com participação de diferentes atores. As fontes do direito são resultado desse Poder Legislativo.

No plano internacional, para uma nova compreensão do fenômeno, é necessária a inclusão das noções de fragmentação, descontinuidade das normas e heterarquia como análises de sintomas a serem utilizadas como fontes acessórias atuais à descrição da sociedade. Elas têm a forte função de denúncia, uma descrição própria da entropia da atual ordem jurídica internacional e de suas fontes.

Ao mesmo tempo, a incorporação de normas internacionais e seu devido processo legislativo ainda é a forma pela qual essas ordens normativas tradicionalmente são consolidadas nos Estados soberanos. O problema é que a produção dessas normas não é estudada com vista ao déficit democrático normalmente implicado no processo de que decorrem, sendo enfrentada como um simples problema formal de fontes do direito.

\footnotetext{
${ }^{70}$ Ambos os casos serão detalhados no decorrer do capítulo. Sobre pessimismo democrático em organizações internacionais e déficit democrático: DAHL, Robert. Can international organizations be democratic? A skeptics's view. In: Shapiro, Ian \& Hacker-Cordon, Casiano (eds.) Democracy'sEdges. Cambridge University Press, 1999, pp. 19-40.

71 "O processo democrático da criação do direito constitui a única fonte pós-metafísica da legitimidade." In: HABERMAS, Jürgen. Direito e Democracia: entre a Faticidade e a Validade, v.I, . Rio de Janeiro: Tempo Universitário, 2003. p. 310. Também ver Luhmann: "Especialmente porque a pergunta pelo fundamento de legitimidade do Estado de Direito poderia ser respondida tanto apontando para o velho direito natural, como também para uma nova referência comunicativa: os procedimentos legais de criação do direito no âmbito do poder político estatal." LUHMANN, Niklas. Legitimação pelo procedimento. Tradução de Maria da Conceição Corte-Real. Brasília, UnB, 1980. P. 145.
} 
Entende-se que tanto o modo de negociação dos acordos internacionais, delegado por lei ao Ministério das Relações Exteriores, como o processo de aprovação dos tratados pelo Congresso Nacional são pouco transparentes e não oportunizam o amplo debate público e participação popular $^{72}$. Por isso, a superação de um modelo de separação de poderes pelo qual há pouco ou nenhum diálogo e intervenção entre Poder Legislativo e Poder Executivo em matéria de política externa precisa ser problematizada, desde a incorporação de normas internacionais ao seu debate diplomático primário.

A falta de transparência e de legitimidade são elementos que caracterizam esse déficit democrático, o qual aponta para um segundo problema, da subsequente dificuldade de aceitação social de normas e sua validade política ${ }^{73}$. De um ponto de vista descritivo, o déficit democrático de instituições internacionais foi considerado, inicialmente, como um problema puramente acadêmico. Entretanto, com a participação massiva em cúpulas mundiais da ONU e as reuniões mundiais paralelas às oficiais, como o caso do Fórum Mundial Social em oposição ao Fórum Econômico de Davos, mudou-se paulatinamente esta percepção ${ }^{74}$. Isso significa dizer que o déficit de legitimidade normativa de instituições internacionais tem gerado reações sociais e, portanto, são sintomas relevantes.

Essa inquietação com o desenho institucional de espaços extranacionais deve-se precisamente a crescente destaque e multiplicação de normas internacionais. Com efeito, parlamentos extranacionais e a diplomacia parlamentar são pontos de identificação com uma literatura neoinstitucionalista, que vai da formação de preferências dentro de uma perspectiva doméstica ou regional nos parlamentos supranacionais até uma avaliação sobre o seu nível

\footnotetext{
${ }^{72} \mathrm{O}$ art. 27, inciso XIX da Lei 10.683/2003 confere competência ao Ministério das Relações Exteriores do Brasil nas áreas de: "a) política internacional; b) relações diplomáticas e serviços consulares; c) participação nas negociações comerciais, econômicas, técnicas e culturais com governos e entidades estrangeiras; d) programas de cooperação internacional; e) apoio a delegações, comitivas e representações brasileiras em agências e organismos internacionais e multilaterais. In: BRASIL. LEGISLAÇÃO. LEI No 10.683, DE 28 DE MAIO DE 2003.

${ }^{73}$ ZURN, Michael. Global Governance and Legitimacy Problems. Government and Opposition - An International Journal of Comparative Politics, vol. 39, no. 4, 2004.

${ }^{74}$ As Cúpulas Mundiais da ONU têm início na década de 70, passam por uma intensa atividade na década de 90, incluindo variados assuntos, abrindo uma complexa e importante relação com as organizações da sociedade civil. Todas as conferências contam com um número expressivo de delegações, especialmente ONGS, e inúmeros documentos produzidos. In: PIANTA, Mario. UN World Summits and Civil Society. The State of the Art. United Nations Research Institute for Social Development. 2005. A ideia do Fórum Social Mundial - FSM surgiu entre um grupo de brasileiros que desejavam opor resistência ao pensamento único do neoliberalismo, tão eloquentemente expresso nas mais de vinte reuniões anuais do Fórum Económico Mundial em Davos. O FSM é o conjunto das iniciativas de intercâmbio transnacional entre movimentos sociais, organizações não-governamentais (ONGs) e os seus conhecimentos e práticas das lutas sociais locais, nacionais e globais, levadas a cabo em conformidade com a Carta de Princípios de Porto Alegre contra as formas de exclusão e de inclusão, de discriminação e igualdade, de universalismo e particularismo, de imposição cultural e relativismo, produzidas ou permitidas pela fase atual do capitalismo conhecida como globalização neoliberal. In: DE SOUSA SANTOS, Boaventura. O Fórum Social Mundial: manual de uso. Cortez Editora, 2005.
} 
democrático, passando por conceitos como o de déficit democrático e de accountability, que são centrais para uma avaliação da formulação de política externa e da democratização desses $\operatorname{processos}^{75}$.

Nesse panorama internacional, a ideia de constituição ainda é o fundamento importante que sustenta a representação de acoplamento estrutural da diferença entre a política e o direito no âmbito dos Estados e o elemento de entrelaçamento deles.

Assim, após uma revisão crítica da noção de separação de poderes e fontes do direito, será brevemente resgatada a teoria política de Luhmann, que dá esteio ao transconstitucionalismo, para buscar equivalentes funcionais ou interpretações equivalentes para a ordem política legislativa extranacional. $O$ enfoque transconstitucional de entrelaçamento de ordens legislativas, como poder legislativo extranacional, contribui para a compreensão da diplomacia parlamentar e do processo legislativo extranacional.

\subsection{O Processo Legislativo Extranacional}

Todo processo é uma forma. O objetivo de explorar e descrever uma forma analiticamente não é discutir seu conteúdo, mas sua ideologia. Nesta tese, o processo é

\footnotetext{
${ }^{75}$ Ao contrário da teoria crítica, o neoinstitucionalismo tem como prática a repetição e preocupação com o melhoramento das instituições nos seus estudos e avaliações. Essa metodologia possibilita várias inferências válidas, como, por exemplo, a preocupação com o grau de democracia, seus procedimentos e formas de participação. Contudo, fica apenas voltada para procedimentos formais que muitas vezes não refletem as dinâmicas sociais existentes nas redes. Isso vale ainda para o âmbito internacional, que é, muitas vezes, tão distante ao olhar e do perceber. Autores neoinstitucionalistas: DAHL, Robert. Can international organizations be democratic? A skeptics's view. In: Shapiro, Ian \& Hacker-Cordon, Casiano (eds.) Democracy's Edges. Cambridge University Press, 1999, pp. 19-40.; KEOHANE, Robert; MACEDO, Stephen; MORAVSCIK, Andrew. "Democracy-Enhancing Multilateralism." International Organization, vol. 63, no 1, Winter 2009, pp. 1-31.; GRANT, Ruth \& KEOHANE, Robert. Accountability and Abuses of Power in World Politics. The American Political Science Review, vol. 99, n 1, February 2005, pp. 29-43.; MORAVSCIK, Andrew. Is there a 'Democratic Deficit' in World Politics? A Framework for Analysis' Government and Opposition An international Journal of Comparative Politics, vol. 39, n. 2 2004, p. 336-364. ROSENAU, James N. 'Governance, order, and change in world politics'. Rosenau, James; Czempiel, Ernst-otto (eds.). Governance without Government: Order and Change in World Politics. Cambridge: Cambridge UP, 2000. P.1-29 ;ROSENAU, James. "Norms". Along the Domestic-Frontier.Exploring Governance in a Turbulent World. Cambridge Studies in International Relations, $\mathrm{n}^{\circ}$ 53.Cambridge: Cambridge University Press, 1997, pp. 174-188. Sobre deficit democratic: NANZ, Patricia e STEFFEK, Jens. "Global Governance, Participation and the Public Sphere". Government and Opposition - An International Journal of Comparative Politics, vol. 39, no. 4, 2004. RUGGIE, John G. "Reconstituting the Global Domain - Issues, Actors, and Practices". European Journal of International Relations, vol. 10, $\mathrm{n}^{\circ}$ 4, December 2004, pp. 499-531. SCHOLTE, Jan Aart. "Civil Society and Democratically Accountable Global Governance". Government and Opposition An International Journal of Comparative Politics, vol. 39, no. 4, 2004. ZURN, Michael. "Global Governance and Legitimacy Problems". Government and Opposition - An International Journal of Comparative Politics, vol. 39, no. 4, 2004.
} 
entendido como ideologia ${ }^{76}$. Esse axioma é um dos fundamentos da Teoria Crítica das Relações Internacionais ${ }^{77}$, considerado nesta tese como estruturas históricas das instituições ${ }^{78}$. Portanto, para separar o processo legislativo de sua semântica histórica, é necessário refundálo a partir de outros olhares, como o transconstitucionalismo ${ }^{79}$.

O processo legislativo está localizado pelo ciclo sistêmico da política no âmbito da administração, uma vez que será, em regra, previsto na própria constituição de países ocidentais. Descritivamente, o processo legislativo é o iter seriado de atos para o fim legislativo, resultando num determinado conjunto positivista sistemático de conceitos ${ }^{80}$. A análise detalhada desses atos/conceitos pretende explorar o poder de cada ator envolvido no processo e as razões para sua mudança ou permanência.

Assim, toda ideia inicial de processo se revela essencialmente formal e encerra a ideia de que com ele se pretende criar um sistema abstrato que enseje a participação de diferentes atores. "O processo legislativo é formal em dois sentidos. Primeiro, porque está subordinado a

\footnotetext{
${ }^{76}$ Utiliza-se tanto a formulação de Silva (2004) do Processo como ideologia como os fundamentos da teoria crítica. Sobre processo: SILVA, Ovídio Araújo Baptista da. Processo e ideologia: o paradigma racionalista. Rio de Janeiro: Forense, 2004. Também Luhmann: "O processo da legislação parlamentar precisa ser entendido como pacto entre as forças políticas relevantes, fora do processo formal, muito mais do que o simples processo formal." In: LUHMANN, Niklas. Legitimação pelo procedimento. Tradução de Maria da Conceição Corte-Real. Brasília, UnB, 1980. P. 145.

${ }^{77}$ Nesse sentido, a teoria crítica, de forma análoga ao construtivismo, não aceita a cientificidade analítica das teorias das relações. Afirma que todas as teorias são normativas, ou ao menos são superficialmente nãonormativas. Essa neutralidade na verdade mascara uma ordem construída intencionalmente para sustentar o status quo. In: COX, Robert. "Social forces, states and world orders: beyond international relations Theory". In: KEOHANE, Robert. The neorealism and its critics. New York: Columbia, 1986. p.212

${ }^{78}$ A teoria crítica entende que há uma ação humana em todas as presunções assumidas pelas teorias anteriores. As presunções de natureza dos Estados, do egoísmo do homem ou do sistema internacional como anarquia são formas de ideologia. "Teoria crítica é teoria da histórica no sentido de estar preocupada não apenas com o passado, mas com o contínuo processo de mudança histórica". As estruturas históricas do sistema internacional são uma moldura particular da configuração de forças sociais que impõe pressões e limitações. As três categorias de forças, expressadas como potenciais, interagem na estrutura: ideias, capacidades materiais e instituições. Não há determinismo entre essas categorias, há apenas interação. A capacidade material está ligada aos potenciais produtivos e destrutivos, sua forma está ligada a capacidades tecnológicas e organizacionais, fontes naturais acumuladas. In: COX, Robert. Op. Cit. 1986. pp. 215, 209. ss.

${ }^{79}$ A respeito do acolhimento do transconstitucionalismo pela teoria crítica, para evitar uma crítica com a utilização concomitante de Habermas e Luhmann, que se diferenciam em alguns pontos-chaves, como, por exemplo, a legitimação pelo consenso ou situação ideal de fala de Habermas, que poderia fundamentar a ética universal do excluído de Linklater. Por isso, opta-se por não utilizar Habermas no texto. Ver: HABERMAS. J. Direito e Democracia entre facticidade e validade. Vol. 1. $2^{\mathrm{a}}$ Edição. Rio de Janeiro: Tempo Universitário, 2003. p. 71; LUHMANN, Niklas. Poder.Tradução Martine C. Rezende Martins. Brasília: Editora da Universidade de Brasília, 1985.;LINKLATER, A.. "The achivement of critical theory", In: International theory: positivism and beyond. S Smith; K. Booth; M. Zalewski. Cambridge: Cambridge University Press, 1996. p.282.

${ }^{80}$ Conceito baseado em Canotilho e Afonso da Silva. A formação dos atos normativos obedece o iter juridicamente regulado, que se costuma designar como procedimento. Procedimento legislativo é a sucessão de série de atos necessários para produzir um ato legislativo. A lei é o ato final do procedimento. As várias fases procedimentais, disciplinadas com maior ou menor particularização nos vários ordenamentos, estão préordenados à formal a lei formal da Assembleia. In: CANOTILHO, J.J. Gomes. Direito Constitucional e teoria da constituição. Coimbra: Almedina, 2003. P. 871. No processo legislativo, essa meta é o ato legislativo geral, abstrato, obrigatório e modificativo. In: SILVA, José Afonso da, 2006. Op. Cit. p.40.
} 
formalidades previstas na Constituição e nos regimentos internos das Câmaras Legislativas. Segundo, porque é representação ou deve ser dos interesses sociais." ${ }^{\prime 1}$

A matéria envolve a discussão sobre os limites e diferenças entre processo e procedimento. Procedimento seria a atividade de preparação de provimentos estatais ${ }^{82}$, isso é, uma formalidade burocrática do processo, enquanto o processo significaria avançar, caminhar na direção de um fim. Todo processo envolveria, portanto, a ideia de temporalidade, a partir de um ponto inicial até atingir o fim desejado. Ele envolve o afastamento da ideia de instantaneidade da reação e da possibilidade de reações imediatas tomadas pelos competentes, no caso, a competência política ${ }^{83}$. Seguindo esse fundamento teleológico, no qual o processo é dotado de finalidade, enquanto o procedimento não, o procedimento seria a mera externalização do processo $^{84}$.

Contudo, o argumento mais relevante nesse debate envolve a questão da legitimidade e o processo. A ideia de criação de processos, legislativos e judiciais, é fruto de uma criticada separação de poderes do Estado moderno e pretende oferecer um espaço democrático de legitimidade compartilhada entre esses poderes na construção de fontes de direito autônomas e outras esferas da sociedade, como a economia, ciência, entre outros. Assim, a forma com a qual o direito passa a produzir-se a si mesmo são os processos legislativos e judiciais. No paradigma do positivismo jurídico, o problema das fontes do direito se desloca das referências transcendentes ao direito para o problema dos processos jurídicos de criação/aplicação do direito $^{85}$.

O processo legislativo, enquanto processo de justificação democrática do Direito, pode ser caracterizado como uma sequência de diversos atos jurídicos que, formando uma cadeia procedimental, assumem seu modo específico de interconexão, estruturado em última análise por normas jurídico-constitucionais, e, realizados discursiva ou ao menos em termos

\footnotetext{
${ }^{81}$ SILVA, José Afonso da, 2006. Op. Cit. p.41.

${ }^{82}$ Provimentos estatais são atos de caráter vinculante do Estado que geram efeitos sobre a esfera jurídica dos cidadãos. Provimentos podem ser legislativos, jurisdicionais ou administrativos, dependendo do procedimento que os prepara. Mas o procedimento não se esgota na simples preparação do provimento, ele possui uma característica fundamental, a forma específica de interconexão normativa entre os atos que o compõe. In: CATTONI DE OLIVEIRA, Marcelo Andrade. Do processo legislativo: uma justificação democrática do controle jurisdicional de constitucionalidade das leis e do processo legislativo. Belo Horizonte, Mandamentos, 2000.

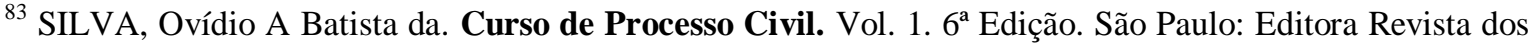
Tribunais, 2002. p. 14.

${ }^{84}$ BARBOSA, Leonardo Augusto de Andrade. Processo Legislativo e democracia: parlamento, esfera pública e jurisdição constitucional. Belo Horizonte: Del Rey, 2010. P. 79.

${ }^{85}$ SIMIONI, Rafael Lazzarotto. "Organização do poder político: o estado constitucional em Niklas Luhmann.

Prismas: Dir., Pol. Publ. e Mundial., Brasília, v. 6, n. 2, p. 329-349, jul./dez. 2009. P. 340.
} 
negocialmente equânimes ou em contraditório entre agentes legitimados $(\ldots)^{86}$.

Com efeito, o elemento do contraditório, isto é, da oportunidade de incluir uma diversidade distinta de atores confere legitimidade ao processo. O procedimento de produção das leis é processo legislativo na medida do desenvolvimento das relações entre seus participantes a partir do princípio do contraditório ${ }^{87}$.

Estabelece-se, assim, uma sequencialização de atos que deve incluir diferentes atores. A forma como esses atos estão organizados, por meio de procedimentos, vai constituindo a validade das decisões sobre a validade das normas. O processo legislativo é o sistema especial de comportamento que trata de determinado método especial de legislação e persegue o objetivo de elaborar uma lei e colocá-la em vigor ${ }^{88}$.

Geralmente, esses atos são previstos nas constituições de cada um dos Estados nacionais, Estatutos constituintes de organizações internacionais ou dos órgãos competentes para a produção de leis. A natureza jurídica da ordem (nacional ou extranacional) e sua configuração política determinarão quais atos são considerados parte do processo legislativo.

Não há um padrão de processo legislativo nacional ou extranacional. Não há nenhuma regra última, norma fundamental ou constituição original que determine quais atos legislativos comporão um processo "padrão" ou "universal".

No Brasil, tendo amparo no Constituição Federal, o conjunto de atos ordinários para produção legislativa inclui: iniciativa, emenda, votação, sanção, veto, promulgação e publicação. De uma perspectiva supranacional/regional, Ventura e Perotti realizam um diagnóstico do processo legislativo do MERCOSUL traçando um paralelo entre o processo legislativo nacional e internacional, respectivamente, conforme o quadro abaixo, ${ }^{89}$

\footnotetext{
${ }^{86}$ CATTONI, Marcelo. Do processo legislativo: uma justificação democrática do controle jurisdicional de constitucionalidade das leis e do processo legislativo. Belo Horizonte, Mandamentos, 2000.

87 BARBOSA, Leonardo Augusto de Andrade. Processo Legislativo e democracia: parlamento, esfera pública e jurisdição constitucional. Belo Horizonte: Del Rey, 2010. p. 79.

${ }^{88}$ LUHMANN, Niklas. Legitimação pelo procedimento. Tradução de Maria da Conceição Corte-Real. Brasília, UnB, 1980. p. 146

${ }^{89}$ VENTURA, Deisy; PEROTTI, Alejandro D. El Proceso Legislativo del Merscosur.KONRAD-

ADENAUER-STIFTUNG E. V.: Montevideo, Uruguay, 2004. p. 20.
} 


\begin{tabular}{|l|l|l|}
\hline \multicolumn{1}{|c|}{ Nacional } & \multicolumn{2}{c|}{ Internacional } \\
\hline $\begin{array}{l}\text { Iniciativa: de membros do legislativo, } \\
\text { executivo, judiciário ou popular }\end{array}$ & $\begin{array}{l}\text { Iniciativa: bilateral, foros multilaterais, organizações } \\
\text { internacionais, comunidade de Estados }\end{array}$ \\
\hline $\begin{array}{l}\text { Discussão } \\
\text { Possibilidade de Referendum }\end{array}$ & $\begin{array}{l}\text { Negociação } \\
\text { Possibilidade de Referendum }\end{array}$ \\
\hline \multirow{2}{*}{ Votação } & $\begin{array}{l}\text { Conclusão (individual/bilateral) ou Deliberação } \\
\text { Coletiva }\end{array}$ \\
\cline { 1 - 1 } Sanção ou Veto & Incorporação & Aprovação Legislativa \\
\cline { 1 - 1 } Promulgação & & Ratificação pelo Executivo \\
\cline { 1 - 1 } Publicação & & Promulgação/Publicação \\
\hline
\end{tabular}

Essa matriz serve como ideia inicial na distribuição dos procedimentos legislativos extranacionais entre ordens legislativas. Contudo, cada Estado, organização internacional, supranacional ou transnacional conta com uma forma específica de atos do seu próprio processo legislativo, sendo inócua a procura por um padrão dentro de uma amostra qualitativa de exploração de casos.

Mesmo se considerássemos uma análise estritamente nacional, em que aparecem as características de iniciativa, emenda, votação, sanção, veto, promulgação e publicação aparecem com mais frequência, não seria possível ter um parâmetro sério sem considerar as formas de governo presidencialista ou parlamentarista e variações, os sistemas jurídicos (Common Law; Civil Law; Customary Law), sistema monista ou dualista de incorporação legislativa e, principalmente, as Constituições de cada país. Assim, o processo legislativo nacional utilizado será o brasileiro, na medida em que será descrito no caso FIFA-Brasil. Também serão citados oportunamente certos processos legislativos nacionais europeus de entrelaçamento do caso União Europeia e Estados-Membros.

O processo legislativo extranacional é ainda mais sui generis. As diferentes ordens internacional, supranacional e transnacional trafegam por vias de atores e interesses diversos. Enquanto a ordem internacional relaciona-se com organizações internacionais e conferências multilaterais, a ordem supranacional é singularizada pela União Europeia e a ordem transnacional tem respaldo nos estatutos de organizações e associações privadas. Nesta tese serão descritos apenas os processos extranacionais trabalhados nos casos: da FIFA, no âmbito transnacional, e da União Europeia, no supranacional.

A partir do valor constitucional fundamental de controle de poder por meios democráticos, uma particularidade do trabalho será desvelar o ator por trás de cada ato legislativo: se desde a iniciativa a votação cabe apenas a um ator ou a uma diversidade de atores; no nosso caso, de entrelaçamento de ordens, também é observada a ordem legislativa de cada ator. 
Uma vez que todo processo legislativo é constitucional, sempre que houver um entrelaçamento lícito de ordens jurídicas de diferentes níveis - estatal, internacional, supranacional e transnacional - confirma-se o caso de transconstitucionalismo, ou, no caso em que isto ocorre ilicitamente, uma corrupção sistêmica.

Portanto, a partir da exploração dos dois casos de entrelaçamentos legislativos, serão detalhados os processos legislativos de cada um, destacando desde a iniciativa, debates, incorporação e publicação final.

\subsubsection{A crítica à separação de poderes e à teoria das fontes}

No Direito internacional, o processo legislativo é abordado pelo viés de fontes do direito internacional, segundo o qual, de acordo com a ideia de soberania estatal, direitos e deveres internacionais dos Estados somente podem resultar da sua vontade expressa ou tácita. Contudo, o diagnóstico de um sistema de direito internacional que passa por uma fragmentação, descontinuidade de normas e heterarquia pode sensibilizar o debate para repensar esse tema ${ }^{90}$.

Desde o desenvolvimento do pensamento neopositivista jurídico, o Direito tem origem nas suas fontes, como direito autofundado, a partir de um processo legislativo que diz o que é lícito-ilícito no seu próprio sistema ${ }^{91}$. Esta distinção permite fazer distinções e afastamentos momentâneos da moral, da religião, da política, e/ou dos costumes ${ }^{92}$. É o critério de validação de um sistema jurídico. Essa questão é resolvida, na modernidade ocidental, pelo acoplamento estrutural da Constituição, no sistema do direito ordinário, seguindo, nesse aspecto, o neopositivismo jurídico.

90 KOSKENNIEMI, Martti. International legislation today: Limits and possibilities, Wisconsin International Law Journal Vol. 23, No. 1, 2008. DELMAS-MARTY, Mireille. Revista Penal. Estudios jurídicos comparados e internacionalizacióndelderecho. Publicado por Librairie Arthème Fayard 2003, Paris.; GOLDSMITH, Jack L.; POSNER Eric A. The Limits of International Law. Oxford: Oxford University Press, 2005. Mas também nos autores clássicos do neo-realismo: WALTZ, Kenneth, Man, The State and War. Columbia University Press, 1959..;TEUBNER, Gunther. Global Bukowina: Legal Pluralism in the World Society. In: Gunther Teubner (ed.) Global Law Without a State. Dartmouth: Aldershot, 1996. p. 328.

${ }^{91}$ KELSEN, Hans. Teoria pura do direito. 6. ed. Traduzido por João Baptista Machado. São Paulo: Martins Fontes, 1998.

${ }_{92}$ Referência implícita às ideias de diferenciação funcional de LUHMANN, Niklas, El Derecho de La

Sociedad. Tradução Javier Torres Nafarrate. México: Editorial Herder, 2005. 
Assim, a fonte primordial de todos os sistemas jurídicos seria a Constituição e a legislação infraconstitucional, conforme os critérios formais e materiais que a primeira estabelece. De legislações internacionais a decisões dos tribunais, passando pelo próprio trabalho legislativo do Estado, a Constituição seria posta como critério de racionalidade do sistema jurídico.

A legislação, como fonte de direito, também seria um acoplamento estrutural fraco ou periférico. Ela se converte num mecanismo importante de compensação de tempo para a sociedade em seu conjunto, construindo essa tal forma jurídica, que dá acesso ao sistema do direito e, ao mesmo tempo, limita as expectativas para o sistema da política. "A legislação se coloca a funcionar e chega ao fim com relativa rapidez, com tal que haja suficiente pressão política. A promulgação de uma lei (isto é, a reação do sistema jurídico na direção desejada pela política) é um símbolo de êxito político: o triunfo do grupo que nesse momento está no poder."93

Com a mesma racionalidade, a teoria tradicional do direito internacional afirma que, para o direito internacional positivo, direitos e deveres internacionais dos Estados somente podem resultar da sua vontade expressa ou tácita ${ }^{94}$. Essa forma de pensar está associada à noção de clássica de soberania e à criação do Estado Moderno ${ }^{95}$.

O Direito internacional é o conjunto de normas que regulam as relações entre os Estados. Declarando-se soberanos, estes não reconhecem nenhuma autoridade acima deles. Esta pretensão dá as normas jurídicas que regulam as suas relações um caráter original que as diferencia das normas de Direito interno. Enquanto neste último os sujeitos de direitos são colocados sob um poder que estabelece a lei e a faz respeitar, os Estados, sujeitos do Direito internacional, promulgam em comum, por meio de acordo, a regulamentação que exprime o interesse de todos, cabendo a cada um deles avaliar a dimensão do dever que lhe incumbe e as condições de sua execução ${ }^{96}$.

Essas concepções geraram uma necessidade de fontes positivas para o direito internacional público, desassociado de qualquer preocupação com processos legislativos no plano internacional. E, assim, os processos de criação legislativa na sociedade internacional

93 LUHMANN, Niklas. Derecho de la Sociedad. $2^{\text {a }}$ Ed. México: Universidad Iberoamericana; Herder. 2005.p. 494.

94 ACCIOLY, Hildebrando; SILVA, Geraldo Eulálio N; e CASELLA, Paulo Borba. Manual de Direito Internacional Público, 16 ${ }^{\text {a }}$ ed. (revista, atualizada e ampliada). São Paulo: Saraiva, 2008. p.140.

95 O direito deixa de ser sacro e torna-se soberano: a legislação, a execução e a aplicação das leis tornam-se três momentos no interior de um único processo circular regulado politicamente. Com o absolutismo, passase de uma indiferenciação sacramente fundada de poder e direito para uma subordinação instrumental do direito e à política. In: NEVES, Marcelo. Op. Cit. 2009.

${ }^{96}$ DUPUY, René-Jean. O Direito Internacional. Livraria Almedina. Coimbra, 1993. 
raramente foram estudados. Por influência neopositivista, associou-se a criação do direito internacional às fontes de legislação internacional enunciadas pelo artigo 38 do Estatuto da Corte Internacional de Justiça ${ }^{97}$.

Esse artigo enumera fontes de direito internacional nas quais a Corte fundamentará sua decisão das controvérsias que lhe forem submetidas: as convenções internacionais, quer gerais, quer especiais, que estabeleçam regras expressamente reconhecidas pelos Estados litigantes; o costume internacional, como prova de prática geral aceita como sendo direito; os princípios gerais de direito reconhecidos pelas nações civilizadas; e, excepcionalmente, as decisões judiciais e a doutrina dos juristas mais qualificados das diferentes nações, como meio auxiliar para a determinação de regras de direito.

No debate das fontes de direito internacional, não há preocupação de como se dá o processo legislativo formal e seu processo político, o processo legislativo. A atenuação desse problema comporta um sério risco. Desconsiderar o processo legislativo ou seu equivalente funcional na sociedade, no sistema da política, é correr o risco da não diferenciação entre política e direito no plano internacional. Isso significaria manter a ordem social hierárquica no âmbito internacional, confirmando a hipótese neorrealista e remetendo a sociedade internacional ao estado absoluto de anarquia. Implicaria, ainda, a impossibilidade/dificuldade de questionar o status quo dominante.

Por isso, há necessidade de uma nova compreensão das fontes do direito como processo legislativo entrelaçado de ordens legislativas que permita observar uma evolução e diferenciação no campo da política internacional.

A diferenciação moderna entre política e direito, que implica na formação do Poder Legislativo, consubstancia-se no ideal de separação de poderes. Em sociedades democráticas, o indivíduo conquista a possibilidade de participar das decisões do Estado, ainda que não de forma direta, mas por meio de seus direitos políticos de votar e ser votado num representante e do processo formal de Legislatura.

$\mathrm{Na}$ Roma antiga, essa divisão de poder tinha o objetivo de garantir a liberdade política, mesmo que a liberdade civil ainda fosse limitada. Então, os plebeus e patrícios podiam compartilhar o acesso ao poder, ainda que outras classes estivessem excluídas. Esse equilíbrio explica que o acesso ao bem público fosse modificado gradualmente:

Pois que em um Estado livre todo homem que se reconhece uma alma livre deve ser governado por si mesmo, seria necessário que o povo, em corpo,

\footnotetext{
${ }^{97}$ SHAW, Malcolm. International Law. Cambridge: University Press, 2008.
} 
possuísse o poder legislativo; mas assim como é impossível nos grandes Estados e é sujeito a muita desordem nos pequenos, ocorre que o povo faça por meio dos seus representantes tudo aquilo que não pode fazer por si próprios $^{98}$.

Ainda no Império Romano, já se observava um esboço da divisão de poderes, como relata Montesquieu, no Espírito das Leis. A forma pura ou absoluta da teoria da separação de poderes afirma que: o governo deve estar divido entre três ramos, Legislativo, Executivo e Judiciário; cada ramo é limitado ao exercício próprio de sua função e não pode se permitir usurpar as funções de outros ramos; os três órgãos devem ser compostos de membros diferentes e não podem permitir que um indivíduo pertença a mais de um ramo ao mesmo tempo ${ }^{99}$.

É preciso notar que os três poderes podem estar bem distribuídos em relação à liberdade da constituição, ainda que não o estejam tão bem em relação à liberdade do cidadão. Em Roma, como o povo tinha a maior parte do poder legislativo, uma parte do poder executivo e uma parte do poder de julgar, constituía um grande poder que devia ser equilibrado por outro ${ }^{100}$.

Da República em Roma à passagem do absolutismo à democracia moderna, impõe-se a forma de dividir o poder. O Estado Moderno é definido, desde seu surgimento, como estrutura secularizada e unificada de poder, necessitando da separação dos poderes em determinado momento de sua evolução, por motivos políticos, que permitiram a passagem do absolutismo monárquico ao liberalismo constitucionalista democratizante ${ }^{101}$.

Foi uma assembleia de nobres (barões) que impôs ao rei João Sem Terra a assinatura da Magna Carta inglesa, em 1215. Mas o povo estava ausente, de sorte que só se tem, mesmo, como as primeiras assembleias representativas aquelas que se foram a partir da admissão dos membros das classes livres das cidades e vilas aos corpos políticos deliberantes, junto com os nobres e prelados. E assim se reuniu na Inglaterra, em 1295, formada de prelados, barões e deputados dos condados, cidades e burgos, constituindo uma representação completa de todos os estamentos sociais ${ }^{102}$.

${ }^{98}$ MONTESQUIEU, Charles de Secondat. Espírito das Leis. São Paulo: Martins Fontes, 1996. P. 75.

99 MANIN, Bernard. Frontières, Freins et Contrepoids: La Séparation des pouvoirs dans le débat constitutionnel américan de 1787. Revue française de science politique, Année 1994, Volume 44, Numéro 2. p. $257-293$. p. 260

${ }^{100}$ MONTESQUIEU, Charles de Secondat. Espírito das Leis. São Paulo: Martins Fontes, 1996. p. 193.

101 SALDANHA, Nelson. O Estado Moderno e a Separação de Poderes. São Paulo: Saraiva, 1987. p. 83-4.

${ }^{102}$ SILVA, José Afonso da. Processo Constitucional de Formação das Leis. $2^{\text {a }}$ ed. São Paulo: Malheiros, 2006. P. 47 
As revoluções liberais na França e nos Estados Unidos são marcos para o início da aquisição de novos direitos civis, políticos e sociais, mas também resultam na separação dos poderes. Esses direitos não são promulgados rapidamente, são conquistas históricas e não lineares ${ }^{103}$. A divisão de poderes estabiliza-se somente a partir da ideia de direitos fundamentais, fenômenos novos, como a construção de leis objetivas. Assim, o sistema de freios e contrapesos difunde-se entre os novos Estados de Direito, principalmente onde Constituições nacionais foram elaboradas com legítimo intuito democrático ${ }^{104}$.

De fato, o princípio da separação de poderes tem sua primeira objetivação positiva na Constituição estadunidense de 1787, que foi a primeira carta política que a admitiu, universalizando-a para o constitucionalismo moderno ${ }^{105}$. O princípio democrático de Abraham Lincoln, governo do povo, pelo povo e para o povo, torna-se constitucionalmente consagrado. Ele é mais do que um método ou técnica para os governantes escolherem os governados, pois, como princípio normativo, deve ser considerado nos seus vários aspectos políticos, econômicos, sociais e culturais: ele aspira tornar-se impulso dirigente de uma sociedade, contendo dimensões materiais e dimensões organizativo-procedimentais ${ }^{106}$.

A Constituição do Estado Democrático de Direito institucionaliza tanto o procedimento eleitoral e a "divisão de poderes" quanto os direitos fundamentais. Aqueles configuram exigências primariamente políticas, estes, jurídicas. (...) Assim é que a eleição como procedimento político importa o voto como direito fundamental, a "divisão de poderes", o controle jurídico da política mediante, sobretudo, as garantias fundamentais contra a ilegalidade do $\operatorname{poder}^{107}$.

O conceito moderno de legislação surge com a criação deliberada de normas gerais por um órgão central, caracterizado por reunir representantes do povo ou de uma classe do povo. A distinção teórica decorrente dos três poderes é incorporada pela maioria das democracias e monarquias constitucionais modernas. "A criação de normas gerais, em

\footnotetext{
${ }^{103}$ Ver: COMPARATO, Fábio Konder. A Afirmação Histórica dos Direitos Humanos. São Paulo: Editora Saraiva. 1999.

${ }^{104}$ PECES-BARBA MARTÍNTEZ, Gregório. Primera parte: Sentido y contenido de la Declaración de 1789 y textos posteriores. In: PECES-BARBA MARTÍNTEZ, Gregório; FERNÁNDEZ GARCIA, Eusebio; DE ASÍS ROIG. Historia de los Derechos Fundamentales. Tomo. II: Siglo XVIII Vol. III. Madrid: Editorial Dukinson S. L., 2001. p. 213.

${ }^{105}$ NEVES, Marcelo. Op. Cit. 2009.

${ }^{106}$ In: CANOTILHO, J.J. Gomes. Direito Constitucional e teoria da constituição. Coimbra: Almedina, 2003. P. 288.

${ }^{107}$ NEVES, Marcelo. 2006. Op. Cit. p.102.
} 
princípio, de todas as normas gerais, de todas as leis - pertence ao corpo legislativo, sozinho ou com o chefe do Estado" ${ }^{\prime 108}$.

Na maioria das constituições ocidentais, em que figura a forma de divisão de poderes, as limitações que cada poder impõe ao outro são garantias contra o despotismo e toda forma de autoritarismo, como uma garantia democrática. "Se os três poderes - o de fazer leis, o de executar as resoluções públicas e o de punir os crimes ou solver pendências entre particulares - estivessem reunidos num só homem ou associação de homens, isso redundaria na máxima concentração de poderes do despotismo, implicando a total abolição da liberdade política."109

Para que se manifeste a separação de poderes são necessários dois elementos: especialização funcional e independência orgânica. Assim, as funções especializadas (legislativa, executiva e jurisdicional) são entregues a órgãos separados, dotados de autonomia: nesse momento, sim, fala-se a separação de poderes ${ }^{110}$, que atribui o poder de legislar ao Parlamento, órgão de caráter representativo. Esse representante tem direitos e deveres limitados pela própria lei, nos casos modernos, pelas Constituições.

Mas as fronteiras da soberania não são absolutas. Embora o conceito de separação de poderes designe um princípio de organização política, sendo possível definir fronteiras que separem cada uma dessas três funções, os atuais sistemas de governo desmentem esse ideal ${ }^{111}$.

Todos sabem que o ideal político da "separação de poderes" é impraticável na sociedade contemporânea. Mas o Direito ainda não absorveu este fato político. Para ele a história parou no século XIX. Certamente nossos magistrados procuram formar direito, embora o façam dissimuladamente. Tanto o sistema quanto a doutrina lhe dão cobertura para proteger e praticar o dogma da "separação de poderes" $"$.

Assim, uma crítica recorrente no tema recai sobre a grande assimetria de poder, apesar da separação de poderes. Há uma predominância significativa do Executivo no Estado contemporâneo. Essa predominância é também caracterizada por uma forte influência no Poder Legislativo. Esse fato de influenciar significativamente o processo legislativo para

\footnotetext{
${ }^{108}$ KELSEN, Hans. Teoria Geral do Direito e do Estado. $3^{\text {a }}$ Ed. São Paulo: Martins Fontes, 1998. P. 366.

${ }^{109}$ BONAVIDES, Paulo. Ciência Política. São Paulo: Malheiros, 2006. p. 150.

${ }^{110}$ SILVA, José Afonso da. Processo Constitucional de Formação das Leis. $2^{\text {a }}$ ed. São Paulo: Malheiros, 2006. P. 47.

${ }^{111}$ KELSEN, Hans. Teoria Geral do Direito e do Estado. $3^{\text {a }}$ Ed. São Paulo: Martins Fontes, 1998. P. 385.

112 SILVA, Ovídio Araújo Baptista da. Processo e ideologia: o paradigma racionalista. Rio de Janeiro: Forense, 2004. P. 318
} 
assegurar resultados consistentes com suas preferências é referido por alguns autores de teoria da preponderância executivo ${ }^{113}$.

Também sob a perspectiva de modelo de organização do poder, há uma forte crítica no seio da separação de poderes. A doutrina marxista-leninista repudia o princípio de separação de poderes, porque ele conduziria cada vez mais ao enfraquecimento da verdadeira função da lei - que é obra do parlamento - em proveito dos outros poderes, especialmente do poder executivo ou administrativo ${ }^{114}$.

Essa crítica torna-se ainda mais contundente quando se trata de Poder Legislativo e relações internacionais. No Brasil, essa relação, no âmbito nacional, é ilustrada por meio da evolução política brasileira, consolidada por meio de suas constituições durante todo o século XX. O Poder Executivo negocia o tratado e posteriormente o submete a voto de aprovação ou rejeição, sendo ele normalmente aprovado. Assim, o Poder Legislativo federal dispõe de prerrogativas de competência para aprovação dos tratados internacionais ordinários, conditio sine qua non da vigência dos últimos ${ }^{115}$.

Nas constituições brasileiras, tanto na Constituição de 1967 quanto na de 1988, o Poder Executivo, em comparação com os demais poderes, tem um papel eminentemente concentrado nas fases de formulação e decisão da política externa. As competências do poder Executivo em ambas as Constituições não foram modificadas na sua essência ${ }^{116}$.

Assim, os rumos da política externa e os métodos de ação diplomática no Brasil têm sido confiados ao Poder Executivo. O Parlamento, por sua vez, exerce controle sobre a atividade governamental, desempenhando não um papel ativo e positivo, mas passivo e negativo.

Esse insulamento burocrático da política externa encontra abrigo na legitimidade atestada pela estabilidade do princípio constitucional da competência do Executivo na

\footnotetext{
${ }^{113}$ PEREIRA, Carlos; MUELLER, Bernardo. Uma Teoria da Preponderância do Poder Executivo: o sistema de comissões no sistema brasileiro. REVISTA BRASILEIRA DE CIÊNCIAS SOCIAIS - VOL. 15 No. 43. junho/2000. Sobre o tema: LIJPHART, Arend. Modelos de Democracia, Rio de Janeiro, Civilização Brasileira, 2003. DAHL, Robert. On Democracy, New Haven: Yale University Press, Part III cap.9- 11, p.100-130. 1998.

${ }^{114}$ DAVID, René. Os grandes sistemas do direito contemporâneo. 4. ed. São Paulo : Martins Fontes, 2002. P. 256.

${ }^{115}$ VENTURA, Deisy; SEITENFUS, Ricardo Antônio Silva. Introdução ao direito internacional público. $3^{\mathrm{a}}$ Ed. rev. ampl. Porto Alegre: Livraria do Advogado, 2003. p. 35.

${ }^{116}$ Exceto quanto à avaliação de questões relativas à guerra, fase para a qual não há previsão na Constituição vigente. In: SANCHEZ BADIN, M. Ret al. Política externa como política pública: uma análise pela regulamentação constitucional. Revista de Sociologia e Política Vol. 27, 2006 125-143.
} 
condução da política externa. "Duas políticas governamentais têm sido mais insuladas do jogo legislativo: a política econômica e a política externa, mas por razões diferentes.","17

\begin{abstract}
Esta delegação é fruto da percepção entre as forças políticas e sociais de que a política externa tem sido um instrumento de desenvolvimento importante, ou pelo menos assim o foi no período do modelo de substituição de importações. Neste sentido, a mudança do modelo de inserção internacional com a abertura econômica e as modificações decorrentes na política externa, em especial a adesão do Brasil aos novos regimes econômicos internacionais, de propriedade intelectual, serviços e outros sistemas normativos internacionais, tendem a erodir esta delegação prévia, na medida em que a internalização de novas normas e disciplinas internacionais inevitavelmente gera a politização interna da política externa ${ }^{118}$.
\end{abstract}

Uma maior participação do parlamento seria, de todo modo, desejável por uma simples questão de legitimidade, sobretudo porque a discussão em âmbito parlamentar possibilita a participação mais ativa da sociedade em temas de seu interesse, contribuindo para uma condução mais transparente dos assuntos externos ${ }^{119}$.

A legitimidade do Poder Legislativo no Brasil e do conjunto do sistema de freios e contrapesos poder ser questionada com base em diferentes críticas. A crescente participação social no processo decisório de organizações internacionais de toda ordem é combinada com as tradicionais representações de governos nacionais. Em geral, esse processo legislativo extranacional, que produz tratados internacionais e regras internacionais cogentes,comporta exclusivamente a representação dos órgãos executivos. Evidentemente, o Poder Executivo tem competência para convidar qualquer outro ator a integrar a delegação nacional. Portanto, toda a abertura à participação de parlamentares, no Brasil, é atualmente discricionária.

Em 1982, contudo, o deputado José Frejat submeteu um projeto de lei que pretendia modificar essa concepção. O Projeto de Lei n. ${ }^{0}$ 5.974/1982 dispôs sobre a participação de representantes parlamentares oposicionistas em missões oficiais brasileiras no exterior. $\mathrm{O}$ projeto previa, em seu artigo primeiro, a presença obrigatória de pelo menos um representante indicado pela oposição em toda missão oficial do governo brasileiro ao exterior. Conforme a justificativa do deputado autor:

\footnotetext{
${ }^{117}$ DE CASTRO NEVES, João Augusto. O Papel do Legislativo nas Negociações do Mercosul e da ALCA. Contexto Internacional 25.1. 2003.103-138.

${ }^{118}$ DE LIMA, Maria Regina Soares. A política externa brasileira e os desafios da cooperação Sul-Sul. Revista Brasileira de Política Internacional 48.1, 2005. $24-59$.

${ }^{119}$ VENTURA, Deisy; SEITENFUS, Ricardo Antônio Silva. Introdução ao direito internacional público. $3^{a}$ Ed. rev. ampl. Porto Alegre: Livraria do Advogado, 2003. p. 35.
} 
É da índole democrática a fiscalização dos atos do Governo pela Oposição. Os representantes do povo, eleitos pelas legendas oposicionistas, têm o dever de exercer essa tarefa. É bem verdade que os atos, tratados e convenções internacionais, firmados pelo governo brasileiro, vêm ao Congresso para apreciação. Todavia, na maioria das vezes, o Parlamento não dispõe de muitos dados para aferir as reais condições que predominavam quando da celebração daquele ato internacional. ${ }^{120}$

Contudo, o projeto obteve um parecer fortemente desfavorável emitido pelo Consultor do Itamaraty, M. Franchini-Neto. Este se manifestou por sua inconstitucionalidade, além de afirmar que o projeto era desnecessário e contrário aos interesses nacionais.

Ele foi declarado inconstitucional com base no argumento de que, pela Constituição da época, de 1969, o art. 62 determinava independência e harmonia dos Poderes. Ao presidente da República, caberia "manter relações com os Estados estrangeiros (art. 81, IX), celebrar tratados convenções e atos internacionais, ad referendum do Congresso Nacional (art. $81, \mathrm{X})$ ”. Segundo o parecerista, “isto significa que não caberá ao Congresso intervir nas negociações, senão após a sua concretização, ficando-lhe, entretanto, livre o acesso ao Ministro de Estado para as informações que julgue necessárias, mediante convocação que lhe dirija."121

Foi considerada desnecessária a presença de qualquer membro do Poder Legislativo, seja ou não de partido ou oposição, pois a gênese dos tratados, convenções e atos internacionais é de competência do Executivo, ao qual se associa ou não o Congresso Nacional, mas sempre a posteriori, tendo em vista a repercussão jurídica interna. $\mathrm{O}$ Congresso deve ser elucidado sobre o pensamento político do Executivo; sem essa precaução a lei será abstrusa. A pretensão legislativa também é contrária aos interesses nacionais e ao “arrepio da imemorial tradição diplomática, zelosamente defendida pelo Ministério de Relações Exteriores."

O projeto foi arquivado sem chegar a ser debatido nas Comissões ou no Plenário. Não se sabe da força que teve ou tem um parecer consultivo, nota-se seguramente força que o Ministério das Relações Exteriores faz ao tentar blindar-se da intervenção alheia. Nesse caso, seria um passo inédito em direção à democratização das missões diplomáticas brasileiras.

\footnotetext{
${ }^{120}$ BRASIL. DIÁRIO DO CONGRESSO NACIONAL. (Seção I) Março de 1982. P. 1559.

121 FRANCHINI-NETTO, M. Projeto de Lei n. ${ }^{\circ}$ 5.974/1982, que dispõe sobre a participação de representantes oposicionistas em missão oficial brasileira no exterior. Brasília, 1982. In: MEDEIROS, Antônio Paulo Cachapuz (Org.) Pareceres dos Consultores Jurídicos do Itamaraty. Vol VIII (1972-1984). Brasília: Senado Federal, 2004. pp. 358-361.

122 FRANCHINI-NETTO, M. Projeto de Lei n. ${ }^{\circ}$ 5.974/1982, que dispõe sobre a participação de representantes oposicionistas em missão oficial brasileira no exterior. Brasília, 1982. In: MEDEIROS, Antônio Paulo Cachapuz (Org.) Pareceres dos Consultores Jurídicos do Itamaraty. Vol VIII (1972-1984). Brasília: Senado Federal, 2004. pp. 358-361.
} 
Desde então, nenhum passo significativo foi dado em direção a uma maior participação do Congresso Nacional.

Portanto, o que se observa hoje é a contínua blindagem do Poder Executivo à participação da diplomacia parlamentar em assuntos internacionais, ao menos no caso brasileiro. A separação de poderes é uma ficção que vai além da perspectiva de organização e divisão do poder nacional. Ela concentra também os poderes na atuação internacional do país, minguando a participação de outros poderes, diminuindo seu debate doméstico, sob o pretexto constitucional formal.

Ao contrário, sob uma perspectiva constitucional material, a inclusão do contraditório, a participação de diferentes atores no trabalho legislativo são aspectos pétreos na concepção de um Estado que organiza e divide seu poder sob princípios democráticos.

\subsubsection{Sintomas e novos pontos de partida}

Num sistema descentralizado, nenhum processo pode reivindicar prioridade e diferentes processos podem ser contratados de forma simultânea ou em competição uns com os outros. Mas, em um sistema fragmentado, não existem ponteiros fáceis para determinar qual é a forma mais adequada para se aproximar do processo legislativo em uma instância específica, ou que processo será mais provavelmente considerado legítimo e por quem. Alegase que a participação de atores não estatais democratizou o direito internacional e, portanto, conferiu-lhe maior legitimidade ${ }^{123}$.

Outro ponto de partida para uma nova visão das fontes do direito também passa pelos acontecimentos sociais que transformam a sociedade, como a globalização, que é um tema que dispensa conceitos introdutórios ${ }^{124}$. O importante a destacar é o tipo de contribuição que esse termo pode dar à diplomacia parlamentar e aos processos legislativos extranacionais. A globalização representa a reordenação da sociedade a partir de um modo de (re)produção de informações e de normas produzido por um número dinâmico e complexo de instituições. O

\footnotetext{
${ }^{123}$ KOSKENNIEMI,Martti, 2007. Op. cit.

124 Para a epistemologia, gênese e desenvolvimento da globalização: ARNAUD, André-Jean. Eliane Botelho.(orgs). Dicionário da Globalização. Rio de Janeiro: Lumen Juris, 2006.; O Direito entre Modernidade e globalização: lições de filosofia do direito e do Estado. Rio de Janeiro: Renovar, 1999. BAUMAN, Zygmunt. Globalização: as conseqüências humanas. Trad. Marcus Penchel. Rio de Janeiro: Jorge Zahar Ed., 1999; ROCHA, Leonel Severo. O Direito na forma de sociedade globalizada. In: Epistemologia Jurídica e Decisão. $2^{a}$ Ed. São Leopoldo: Editora UNISINOS, 2002.
} 
paradoxo da globalização faz com que haja uma uniformização cada vez maior da vida social ao redor do mundo, ao mesmo tempo em que aumenta sua fragmentação, isto é, a emergência de esferas sociais especializadas e relativamente autônomas de ação e estrutura.

Há uma espécie de medo à globalização e ao enredo internacional: Tudo como se o aparato político-jurídico construído ao longo de mais de dois séculos - Constituições, parlamentos, Estado de Direito, princípios de legalidade, eleições, governo da maioria, separação de Poderes... - fosse, hoje, completamente inadequado, inútil ou contraproducente. (...) Nada indica que a globalização tenha transformado os Estados, a democracia e os direitos em estruturas políticas descartáveis. As alternativas internacionais à ação política no interior do território ainda não ganharam a posição já alcançada por partidos, minorias, oposições ou movimentos de protesto de âmbito nacional ${ }^{125}$.

Precisamente, o sistema político não deve ser descartado ou renegado, mas repensado. A sociedade moderna,destacada como sociedade mundial, apresenta-se como formação social que se desvincula das organizações políticas territoriais, embora estas, na forma de Estados, continuem a exercer dimensões fundamentais à sua reprodução. "A sociedade mundial constitui-se como conexão unitária de uma pluralidade de âmbitos de comunicação em relações de concorrência e, simultaneamente, de complementaridade."

Como resultado, a globalização nos revela sintomas de diagnósticos políticos ainda não resolvidos ${ }^{127}$. A fragmentação social e jurídica é intensificada como técnica e informação ao final século $\mathrm{XX}^{128}$. E, no âmbito da política internacional, novas e ativas instituições internacionais, impulsionadas pelo desenvolvimento de tecnologia, desenvolvem redes de comunicação e informação que modificam a forma de atuação e publicação de resultados ${ }^{129}$.

A figura da fragmentação pode ser observada nos parlamentos extranacionais, em que temas surgem e dão à luz outros, construídos em torno deles. "A fragmentação é ilustrada pelos agrupamentos horizontais de Estados operando ao lado e dentro da ordem jurídica

\footnotetext{
${ }^{125}$ CAMPILONGO, Celso Fernandes. O direito na sociedade complexa. $2^{\text {a }}$ Ed. São Paulo: Saraiva, 2011.

${ }^{126}$ NEVES, Marcelo. Op. Cit. 2009. P. 20.

127 "Sintoma" na referência político-psicanalítica de Slavoj Zizek: "Elas (as reivindicações de Wall Street) são respostas, e os intelectuais deveriam propor as questões para elas. A situação é como a da psicanálise, em que o paciente sabe a resposta (seus sintomas), mas não sabe a que ela responde, e o analista deve formular a questão.” In: ZIZEK, Slavoj. O violento silêncio de um novo começo. HARVEY, David... et al. Occupy. São Paulo, Boitempo, 2012. p.25.

${ }^{128}$ Intensificação no aumento objetivo de legislação, os números de normas internacionais desde sua origem, apenas o direito comunitário europeu elaborou 68.000 textos. In: DELMAS-MARTY, Mireille. Revista Penal. Estudios jurídicos comparados e internacionalización del derecho. Publicado por Librairie Arthème Fayard 2003, Paris; DELMAS-MARTY, Mireille; et al. Pour un nouvel imaginaire politique. Paris: Librairie Arthème Fayard, 2006.; _ Por um direito comum. Martins Fontes, 2004.;

${ }^{129}$ Sobre a mundança da sociedade em rede, ver: CASTELLS, Manuel. A galáxia da internet. Reflexões sobre a internet, os negócios e a sociedade. Rio de Janeiro: Jorge Zahar, 2003
} 
internacional." ${ }^{130} \mathrm{O}$ problema ainda se agrava na medida em que a especialização jurídica e social não é simultânea em todos os campos e territórios, pois que há uma relativa ignorância sobre os campos adjacentes, ou sobre os princípios e práticas gerais do direito internacional. O resultado gera conflitos entre regras e sistemas de regras, divergindo das práticas institucionais e, possivelmente, implicando a perda de perspectiva especialmente para o direito internacional.

A antiga legislação internacional uniforme foi tomada por uma luta hegemônica entre os diferentes atores, cada um representando interesses e perspectivas particulares, mas reivindicando autoridade para as suas próprias instituições, por isso a fragmentação tornou-se um dos desafios à legislação internacional, em conjunto com a desformalização e o império ${ }^{131}$.

A desformalização se caracteriza pela disposição desordenada do direito internacional. Sua forma está muito longe de ser minimamente clara, ou de algum centro administrativo conseguir ter controle suficiente para tanto. "A essência da ideia de direito internacional está no fato de que a própria sociedade que se autolegisla também é a mesma que se governa. Ao contrário da ideia doméstica, onde há indivíduos ou um grupo deles que ocupam uma posição de autoridade hierárquica com poder de impor regras." ${ }^{132}$

No entanto, não se trata de um simples deslocamento de autores e atores. O Direito é formado por uma série de regras que vão além de tratados internacionais, e incluem padrões procedimentais, regras transnacionais e outra série de formas distintas de legislar. Esses procedimentos interferem na forma de sagrar tratados multilaterais, fazendo com que os tradicionais tomadores de decisão, os Estados, sejam submetidos aos órgãos e atores das instituições competentes para o assunto ${ }^{133}$.

Em virtude da extrema especialização do direito internacional, como se vê, por exemplo, nos regimes de direitos humanos e comércio internacional, há uma radical ruptura horizontal entre organizações internacionais, que são gradualmente consideradas autônomas,

130 KOSKENNIEMI, Martti. The Lady Doth Protest Too Much: Kosovo and the Turn to Ethics in International Law, 65 The Modern Law Review, 2002.

${ }^{131}$ KOSKENNIEMI, Martti, 2006 op. cit.

${ }^{132}$ KOSKENNIEMI, Martti, 2006 op. cit

${ }^{133}$ Outros exemplos de desformalização no domínio do meio ambiente ou no uso de recursos são os artigos do projeto de Prevenção de danos transfronteiriços de atividades perigosas da ICL de 1998, bem como, mais genericamente, o sistema de licenças de emissões no âmbito do Protocolo de Quioto de 1992 do Tratado o Rio e o papel da Agência Global do Banco Mundial para o Meio Ambiente na administração dos tratados multilaterais ambientais. In: KOSKENNIEMI, Martti, 2008, op. cit. 
por elas mesmas e pela comunidade internacional. ${ }^{134}$ Mas esta descontinuidade exclui a subordinação estreita entre diferentes conjuntos de regras, não significando que elas tenham plena autonomia. Para evitar esses transtornos, seria necessária uma teoria que fosse, ao mesmo tempo, dialética e síntese, que tivesse como objetivo construir um pluralismo ordenado. Da pluralidade de sistemas pode-se tentar combinar diferentes lógicas, exigindo os processos acima mencionados, políticas alternativas de diferentes figuras. ${ }^{135}$ A fragmentação e a descontinuidade das normas geram estruturas diferentes: estáveis e instáveis.

Quando a moldura do Estado-hierarquia, com legislação política constitucionalmente legitimada no seu topo, se "quebra" sob as pressões da globalização, então a nova moldura, que substitui a antiga moldura da hierarquia, só pode ser heterárquica, e assim se utiliza uma distinção entre centro e periferia na produção da norma jurídica ${ }^{136}$. A hierarquia é um critério de coerência, de ligação entre todo o sistema jurídico. Na teoria neopositiva do direito, ela é um critério de racionalidade do sistema normativo, já que as normas não podem ser consideradas independentemente de suas interações.

O processo legislativo extranacional é um exemplo, em dimensões globais, em que não há o recurso da produção de um código binário "lícito-ilítico", mas se tenta sustentar um código de legitimidade, que se reproduz a si mesmo mediante o processamento de um símbolo de vigência global, como nas ordens transnacionais da lex mercatoria, lex sportiva e lex digitalis.

Cria-se então um paradoxo: um direito sem direito. $\mathrm{Ou}$, mais precisamente: um direito autônomo, em que a estrutura do direito moderno não prevê elementos capazes de remontar uma nova coerência (num sentido de hierarquia) a partir de elementos clássicos. Esta troca de paradigma tem como característica a heterarquia de direitos múltiplos e autônomos.

Pois, mesmo sem uma hierarquia jurídica, este "novo" processo legislativo, entrelaçado, cumpre sua função de elaborar normas, mesmo que para isso seja necessário regular por meio de um direito sem Estado. E o Estado é, justamente, o que dá força e validade ao direito moderno; por isso, os novos processos legislativos internacionais não têm fundamentação no ordenamento jurídico, embora outros elementos virão a integrar essa ideia de direito autônomo."A hierarquia das fontes jurídicas é apenas uma tentativa inadequada de

\footnotetext{
${ }^{134}$ DELMAS-MARTY, Mireille. Revista Penal. Estudios jurídicos comparados e internacionalización delderecho. Publicado por Librairie Arthème Fayard 2003, Paris.

${ }^{135}$ DELMAS-MARTY, Mireille, 2003. Op. Cit.

${ }^{136}$ Centro e periferia são conceitos próprios da Teoria dos Sistemas Autopoiéticos de Luhmann e se referem a distinções em que se leva em consideração o principal tomador de decisão (centro) em desfavor dos outros atores periféricos em relação a sua função. In: TEUBNER, Gunther. Breaking Frames: Economic Globalization and the Emergence of the lexmercatoria.European Journal of Social Theory.5(2): 199-217. p. 207.
} 
evitar esta auto-referência originalmente dada por acumulações de metaníveis, sempre mais novos; mas o nível superior sempre colapsa em uma identidade com o nível mais baixo." "137

A hierarquia da validade jurídica passa a ser substituída pela heterárquica. As fontes, as operações e as decisões não se comportam de uma maneira hierárquica, mas sim de maneira a referir-se ao código do direito (lítico/ilíticito), para uma definição de suas possibilidades operativas.

\subsubsection{Transconstitucionalismo e Sistema Político}

As estruturas instáveis de variadas ordens conectam transversalmente os fragmentos. Isso não se resolve com utopias constitucionais, teleológicas, ou com ordens normativas últimas, mas sim com modelos que ofereçam um tecido dos fragmentos. $\mathrm{O}$ transconstitucionalismo não exige pertinência a uma determinada comunidade, mas sim uma promoção de inclusão generalizada, ou melhor, a redução da exclusão primária crescente, especialmente em relação ao direito, no contexto de uma estrutura heterogênea e diferenciada de comunicações.

Dessa forma, pode-se gerar uma rede de aprendizagem para ambos os lados, mediante a formação de uma rede transversal construtiva, ou seja, o transconstitucionalismo é decisivo para o sucesso nessa área de colisão. Pois, do contrário, internacionalismo e nacionalismo poderiam levar a atitudes destrutivas para os direitos humanos ou fundamentais e, no caso da política, a modelos autoritários e antidemocráticos.

O sistema da política - dentro do transconstitucionalismo -situa-se na diferença entre política e sociedade. A partir dessa diferença, trabalha com a função de tomar decisões que vinculem coletivamente. Para isso, utiliza-se do meio simbolicamente generalizado do poder. Os interesses econômicos que estejam impulsionando um fato novo poderão resultar em uma irritação no sistema da política, que irá tratá-lo através de suas organizações (executivo e legislativo), observar e decidir sobre o que considera importante levar adiante.

O sistema político moderno evolui de um sistema bidimensional para um tridimensional a partir da adoção de modelos democráticos de tomada de decisão. Na verdade, antes da modernidade e das diferenciações funcionais, era difícil pensar em política stricto

137 In: TEUBNER, Gunther. “And God Laughed...” Indeterminacy, Self-reference, and Paradox. In: Law. Stanford Literature Review. N. 7. p. 19. 
sensu. Essa é o principal resultado da mudança do Estado moderno autoritário para o democrático. "Democracia pode ser entendida tanto como uma forma de constituição do corpo político quanto como uma técnica de governo. O termo reenvia ao conceito do direito público e da prática administrativa: ela designa tanto a forma de legitimação do poder quanto as modalidades de seu exercício."

Num sistema bidimensional, as tomadas de decisão ocorrem de cima para baixo. Mas o design dinâmico-democrático modifica essa relação: a constituição implica, então, uma circulação e contracirculação estrutural básica entre administração, política, público e povo $^{139}$. A forma circular perde em segurança, mas é o preço democrático: ganha-se em dinamicidade. Esses conceitos implicam um glossário particular dentro da teoria políticodemocrática de Luhmann.

A administração tem o sentido amplo dos procedimentos de órgãos competentes para a tomada de decisão política e sua execução. A política em sentido estrito diz respeito aos processos de formação de programas partidários, e escolha entre pessoas e programas. $\mathrm{O}$ público é o receptor das decisões. O povo é o público enquanto reage ativamente às decisões da administração ${ }^{140}$.

Essa reestruturação foi realizada gradualmente. O público (esfera pública) surge a partir do Estado e de sua diferenciação interna segundo o esquema de divisão de poderes, e principalmente quando a democratização do sistema político leva à participação em todas as decisões, não apenas nas eleições ${ }^{141}$.

Como consequência da diferenciação dos partidos políticos aparece um âmbito separado de comunicação especificamente da política stricto sensu, situado entre o público e o Estado, que serve de canal de mediação entre eles. Com essa estrutura, a política não pode ser concebida como preparação de atos de domínio, nem como influência sobre o detentor do poder político: é um sistema diferenciado para a própria política ${ }^{142}$. Essa é a política própria da política, isto é, uma mediação necessária dentro do sistema da política, um sistema

\footnotetext{
${ }^{138}$ AGAMBEN, Giorgio. Note liminaire sur le concept de démocratie, In: AGAMBEN, Giorgio et all. (Org.) Démocratie, dans quel état? Paris: La Fabrique editions, 2009. 9.

${ }_{139}$ NEVES, 2009. p. 52. Também em LUHMANN, Niklas. Teoría política en el Estado de Bienestar. Madrid: Alianza Universidad, 2002. p.62.

${ }^{140}$ NEVES, 2009. Op. Cit. P.52.

${ }^{141}$ LUHMANN, Niklas. Teoría política en el Estado de Bienestar.Madrid: Alianza Universidad, 2002. p.63.

${ }^{142} \mathrm{Na}$ verdade, antes da modernidade e das diferenciações funcionais seria difícil pensar em política stricto sensu. Essa é o principal resultado da mudança do Estado moderno autoritário para o processo democrático. In: LUHMANN, Niklas. Teoría política en el Estado de Bienestar.Madrid: Alianza Universidad, 2002. p.62-3.
} 
complexo, autônomo, que opera e está estruturalmente limitado por si mesmo, principalmente da sua política.

A diferenciação entre público e política stricto sensu necessariamente transforma aquilo que era chamado de Estado e que se havia identificado com o sistema político em uma Administração, que inclui governo e legislação, isto é, instituições que se apoiam em mandatos ou em pontos de vista políticos para criarem decisões vinculantes. Com efeito: “o parlamento escreve as leis e adota os meios para se chegar aos fins; o executivo executa os programas decididos politicamente; e o público se submete às decisões e vota por sua vez no parlamento. O poder aponta sempre para uma mesma direção, circularmente, como os ponteiros de um relógio". 143

$\mathrm{Na}$ interpretação desses conceitos, o processo legislativo e a diplomacia parlamentar fazem parte do conceito de administração. Contudo, a diplomacia parlamentar é um ator privilegiado, que pode participar também da política em sentido estrito e da negociação com a esfera pública no plano extranacional. Esses atores teriam - em tese - maior contato com o público que diplomatas do Executivo e teriam, ao mesmo tempo, a legitimidade democrática, pois participam da administração e foram eleitos.

Com essa capacidade circular, o conceito de diplomacia parlamentar torna-se um ator multiangular dentro da perspectiva dinâmica das ordens legislativas extranacionais, na medida em que há espaço institucional dentro da esfera pública mundial para debates nos respectivos procedimentos jurídicos e políticos.

Portanto, a relação entre povo ${ }^{144}$, esfera pública, política stricto sensu e administração é um jogo cuja circularidade inclui a participação de maior diversidade de atores dentro do sistema: políticos, cidadãos e a burocracia do Estado, todos juntos. O poder consegue reagir na sociedade principalmente através do público, que é o objeto das políticas, participa e vota na eleição dos governantes. Estes realizam a política (mediação) entre público e administração, que precisa executar as políticas para ser eleita novamente pelo público.

Contudo, é notável que exista uma dificuldade de observar essa dinâmica no sistema político. Em termos comparativos, o sistema da política e o do direito não tiveram sucesso na

\footnotetext{
${ }^{143}$ LUHMANN, Niklas. Teoría política en el Estado de Bienestar. Madrid: Alianza Universidad, 2002. p.64.

${ }^{144}$ O conceito de "povo" foi introduzido numa fase posterior do pensamento de Luhmann. O povo tem o objetivo de fechar o sistema político no ponto em que o público formado de indivíduos, grupos e organizações, recebedor de ordens, importunado administrativamente, torna-se povo, no ponto em que $a$ volonté de tous, torna-se volonté générale. In: NEVES, 2009. p. 52. O povo constitucional é um elemento legitimador do sistema da política, dentro da lógica circular. A não existência de um povo constitucional, ou algo equivalente, significa a ausência de uma instância que assegure o fechamento operativo do sistema político, que possibilitasse o apoio generalizado no contexto de uma sociedade hipercomplexa.
} 
evolução dentro da sociedade mundial. O sistema moderno da política é estruturado pela burocracia, lentidão e dificuldade de diferenciação na sociedade mundial, multicêntrica. $\mathrm{O}$ código do poder, assim como os equivalentes funcionais de governo/oposição, a dinâmica circular do sistema das relações políticas não obtiveram sincronia direta com o sistema internacional.

\subsubsection{Entrelaçamentos como Processo}

A concepção de entrelaçamentos remete à ligação de estruturas, pontes de transição e aprendizagem entre sistemas. O desenvolvimento do conceito envolve a compreensão de “acoplamento estrutural", que, no caso entre o sistema jurídico e político, é a constituição. O acoplamento estrutural entre o sistema do direito e o sistema da política se instaura pela Constituição. Ele funciona como se um condicionasse o outro. Por um lado, a Constituição vincula ao sistema político com o direito, com a consequência de que ações contrárias à lei comportem o fracasso político; e, por outro, a Constituição torna possível que o sistema jurídico chegue a inovações mediante uma legislação politicamente induzida ${ }^{145}$.

O acoplamento estrutural da Constituição traz orientações para as políticas, como um programa. Portanto, é uma maneira de limite acordado tanto para política quanto para direito. "Esta forma de acoplamento através do Estado constitucional faz possível, em ambos lados (no sistema político e no sistema jurídico), a realização de graus de liberdade superiores, assim como uma notável aceleração da dinâmica própria de cada um dos sistemas" ${ }^{146}$.

A Constituição irá desempenhar um importante papel de irritabilidade recíproca para um aumento de produção de complexidade, em contraposição às pressões que a política pode sofrer. Isso quer dizer que, paradoxalmente, esse acoplamento estrutural irá fazer com que exista uma indiferença recíproca entre política e direito. "O acoplamento estrutural marca as relações de um sistema fechado com o mundo circundante. Trata-se de um equipamento voltado à produção de 'irritações' no interior do sistema. O mundo não interfere nos sistemas fechados, mas ele existe" ${ }^{, 147}$.

\footnotetext{
${ }^{145}$ LUHMANN, Niklas. La Sociedad de la Sociedad. México:Editorial Herder. 2007. p. 620.

${ }^{146}$ LUHMANN, Niklas. El Derecho de la Sociedad. $2^{\text {a }}$ Ed. México: Universidad Iberoamericana; Herder. 2005.p. 540.

${ }^{147}$ MARCONDES FILHO, Ciro. O escavador de silêncios: formas de construir e desconstruir os sentidos da comunicação. Nova Teoria da comunicação II. São Paulo: Paulus, 2004. p. 427.
} 
O acoplamento estrutural forte entre política e direito será sempre a constituição ou, se for fraco, uma legislação. Isso se observa pela diferenciação rigorosa entre sistemas. Sempre que houver uma interferência de um sistema em outro por seu código, haverá uma corrupção sistêmica.

O Poder Legislativo como processo e representação é o lado de dentro do sistema político da constituição. É a forma procedimental e subjetiva de transconstitucionalismo. Por isso, essas duas formas serão desenhadas como reconstrução semântico-histórica a fim de que sejam fortes o suficiente para resistirem estruturalmente e proporcionar a visualização de entrelaçamentos entre ordens legislativas.

Os acoplamentos estruturais, com seu duplo efeito de inclusão e exclusão, tornam mais fácil a concentração de irritabilidade, ao mesmo tempo que preparam, no âmbito de suas possibilidades, para as contingências ${ }^{148}$. Dessa forma, assim como outros acoplamentos estruturais, a ambivalência da Constituição possibilita que ela possa ser vista tanto como instância do sistema político quanto como instituto do sistema jurídico ${ }^{149}$.

Um leitor pouco atento ou não familiarizado com a complexa teoria dos sistemas de Luhmann poderia supor que o conceito de acoplamento estrutural seria suficiente para a autodescrição do sistema mundial da sociedade. $\mathrm{O}$ acoplamento estrutural tem a capacidade (constitucional) de realizar os intercâmbios necessários entre os sistemas da política e do direito. Contudo, sendo rigoroso na leitura teórica, seria arriscado supra dimensionar um conceito apenas para conveniência do intérprete.

Há uma brusca diferença nos sistemas mundiais quando se pensa em política e direito: o território. Dentro da evolução da formação da sociedade, explicada por Luhmann por meio de uma série de paradoxos e diferenciações ${ }^{150}$, a diferenciação mais interessante para o tema de ordens legislativas está na construção ficcional dos territórios. Como todo sistema, o sistema da política diferencia-se comunicativamente por sua função. Contudo, a segunda e terceira diferenciação tomam como base o território.A segunda diferenciação segmenta em sistemas políticos territoriais; a terceira diferenciação se dá na distinção entre Estado e organizações políticas do respectivo território, conforme o esquema centro/periferia, sendo dela derivados governo/oposição e o ciclo público, povo e política.

\footnotetext{
${ }^{148}$ LUHMANN, Niklas. El derecho de la sociedad. Traduzido por Javier Torres Nafarrate. México: Iberoamericana, 2002. p. 511.

${ }^{149}$ NEVES, Marcelo. Transconstitucionalismo. São Paulo: Martins Fontes, 2009.p.33.

${ }^{150}$ Luhmann explica essa relação no caso do direito em: A terceira questão - O Uso criativo dos paradoxos no Direito e na história do Direito. Tradução: Cícero Krupp da Luz; Jéferson Luiz Dutra. Estudos Jurídicos. Vol. 39 N. 1. Jan-Jun. São Leopoldo: Universidade do Vale do Rio dos Sinos, 2006. p.45-52.
} 
A diferenciação segmentária por territórios é muito particular do sistema da política, diferentemente de outros sistemas como economia, ciência e religião. Isso acontece pelo fato da legitimação política ainda estar vinculada a contextos vinculados a esses próprios sistemas territoriais ${ }^{151}$.

Diferentemente de outros sistemas, ciência, economia, técnica ou religião, o território torna-se uma sujeição radical para o sistema da política, pois se torna condição de sobrevivência, de estabilidade e autorreferência para sua própria reprodução. Com a rara e questionável exceção do direito internacional e dos novos espaços de processos políticos extranacionais, toda produção legislativa depende de si mesma.

A criação de normas secundárias e primárias, pela teoria do direito no início do século XX, já desenvolvia esse argumento. O sistema do direito conteria não apenas regras primárias, que regulam o comportamento das partes, mas também regras secundárias, que preveem a sua identificação, sua interpretação, os procedimentos para resolver conflitos, e sua modificação ${ }^{152}$.

Factualmente, não há perspectiva de uma política mundial totalizante, que possa prescindir de Estados e territórios, apenas de movimentos transversais. Assim fica claro que a limitação do acoplamento estrutural do sistema político e do sistema jurídico através de Constituições não tem correspondência no plano da sociedade mundial ${ }^{153}$.

O fato se agrava em uma sociedade globalizada, em que o sistema do direito submerge num impasse institucional em virtude do contraste entre a alta globalização dos sistemas sociais, como a economia, e a insuficiência da globalização política simplesmente institucionalizada. Isto é, o sistema da política não consegue suportar a pressão de seu acoplamento estrutural com o Direito. São geradas, deste modo, formas jurídicas globais diferentes para a economia, mas elas são estranhas a toda legislação, constituição ou hierarquia $^{154}$.

As constituições, tomadas como acoplamentos estruturais, não dão conta do crescente “entrelaçamento de ordens estatais, internacionais, supranacionais, transnacionais e locais no

\footnotetext{
${ }^{151}$ NEVES, Marcelo. Transconstitucionalismo. São Paulo: Martins Fontes, 2009.p.27.

${ }^{152} \mathrm{Na}$ maior parte dos casos a regra de reconhecimento (secundária) não é enunciada; todavia, a sua existência manifesta-se no modo como as regras concretas são identificadas. Evidentemente, quando isso acontece pelas autoridades, como pelos tribunais, é diferente, pois o que dizem tem um estatuto de autoridade especial, que lhe é conferido por outras regras. As regras, portanto, não são necessariamente enfaticamente pronunciadas, mas utilizadas à medida que se compreenda a necessidade. In: HART, Herbert. O conceito de direito. Traduzido por A. Ribeiro Mendes. 3 ed. Lisboa: Fundação Calouste Gulbenkian, 2001. p. 113.

${ }^{153}$ NEVES, Marcelo. Transconstitucionalismo. São Paulo: Martins Fontes, 2009. p. 27.

${ }^{154}$ TEUBNER, Gunther. The King's Many Bodies: The Self-Deconctruction of Law's Hierarchy. Law and Society Review, Volume 31. Number 4.1997 .p.763-787.p. 772.
} 
âmbito de um sistema jurídico mundial em níveis múltiplos, a partir do qual se tem desenvolvido o transconstitucionalismo da sociedade mundial"155.

\begin{abstract}
Assim como os acoplamentos estruturais, os entrelaçamentos, as pontes de transição variam grandemente dependendo das características dos tipos de sistemas envolvidos. Mas a existência de um acoplamento estrutural, embora seja condição necessária, não é condição suficiente para que esteja presente a racionalidade transversal. Os acoplamentos estruturais servem como garantia de autonomias recíprocas mediante a seletividade das influências, relacionando complexidades desordenadas na observação recíproca, os entrelaçamentos promotores de racionalidade transversal servem, sobretudo, ao intercâmbio e aprendizado recíprocos entre experiências com racionalidades diversas, importando a partilha mútua de complexidade preordenada pelos sistemas envolvidos e, portanto, compreensível para o receptor ${ }^{156}$ (grifo nosso).
\end{abstract}

A noção de racionalidade transversal implica uma variação em relação ao acoplamento estrutural. Marcelo Neves cita Lyotard ${ }^{157}$, conhecido pelos jogos de linguagem e por metanarrativas, fundamenta os argumentos de $\mathrm{Welsch}^{158}$, considera a sociedade multicêntrica sob o ponto de vista da heterogeneidade dos jogos de linguagem ${ }^{159}$. "Isso significa que não há um discurso supraordenado, uma vez que a imposição de um jogo sobre o outro importaria na própria destruição da heterogeneidade das esferas discursivas" ${ }^{\text {160 }}$.

A razão transversal implica um status de hiperintelecto, status de razão - não de impor decretos, senão de fazer transições. Ou seja, trata-se de uma razão que não é outorgada aos jogos de linguagens ${ }^{161}$ particulares, mas, ao

\footnotetext{
${ }^{155}$ NEVES, Marcelo. Transconstitucionalismo. São Paulo: Martins Fontes, 2009.

${ }^{156}$ NEVES, Marcelo. Transconstitucionalismo. São Paulo: Martins Fontes, 2009. p. 43.

${ }^{157}$ Metanarrativas e jogos de linguagem são conceitos utilizados pelo filósofo francês Jean-François Lyotard (1924-1998) na obra “A condição pós-moderna”, de 1979. Para sua compreensão é necessária a constatação de que a ciência moderna, sua constituição, estruturou-se sobre a concepção de que existem sentidos a serem desvendados; de que existe a "Verdade" a ser revelada; de que existe a essência e a aparência das coisas e do mundo. In: RANGEL, Marcelo de Mello; PEREIRA, Mateus Henrique de Faria; Valdei Lopes de Araujo (orgs). O giro-linguístico e a historiografia: balanço e perspectivas. Ouro Preto: EdUFOP, 2012.

${ }^{158}$ Não há nenhuma tradução do trabalho do autor a respeito da razão transversal no Brasil, mas um único artigo traduzido que traz o conceito de transculturalidade: WELSCH, Wolfgang. Mudança estrutural nas ciências humanas: diagnóstico e sugestões. Educação, n. 2 (62), p. 237-258, maio/ago. Porto Alegre/RS: Editora PUCRS, 2007.

${ }^{159}$ NEVES, Marcelo. Transconstitucionalismo. São Paulo: Martins Fontes, 2009. p.33.

${ }^{160}$ NEVES, Marcelo. Transconstitucionalismo. São Paulo: Martins Fontes, 2009. p

${ }^{161}$ Os jogos de linguagem foram introduzidos na filosofia por Wittgenstein. Considera-se o século XX como o século da linguagem em boa parte pelo trabalho do autor que contribui para a "virada linguística". Essa virada equivale a fazer da linguagem, de suas estruturas e de seus recursos, o transcendental de toda investigação da faculdade de conhecer, e a dispor a filosofia seja como uma gramática generalizada, principalmente pelo grande pensador da virada Wittgenstein, no Tractatus. In: MARCONDES FILHO, Ciro. O escavador de silêncios: formas de construir e desconstruir os sentidos da comunicação. Nova Teoria da comunicação II. São Paulo: Paulus, 2004. P.384.
} 
contrário, está envolvida com entrelaçamentos que lhe servem como pontes de transição entre heterogêneos ${ }^{162}$.

A questão reside, portanto, no estabelecimento de uma forma de entrelaçamento que tenha um maior potencial de aprendizagem, não apenas na relação entre sistemas funcionais, mas também nos limites e possibilidades de construção de uma racionalidade transversal mediante o aprendizado recíproco e intercâmbio criativo, para além do acoplamento estrutural e, por exemplo, dos limites territoriais dos sistemas político e jurídico.

A ideia normativa da razão transversal aponta para uma justiça sem consenso, para uma justiça em face do heterogêneo, ou de uma forma mais radical, em um consenso justamente sobre o fato de que está em jogo um dissenso de base, a partir do qual não é mais possível acordo relativo ao conteúdo. A atividade da razão não leva ao consenso, mas sim à articulação de dissensos basais ${ }^{163}$. (grifo nosso)

A racionalidade transversal pode ocorrer em três sistemas sociais ao mesmo tempo, como no direito, economia e política. Isto é, importa num grau de aprendizado e intercâmbio construtivo entre esses três níveis ${ }^{164}$. Esse traço também o diferencia do acoplamento estrutural.

A combinação do acoplamento estrutural e da razão transversal resulta num método transconstitucional, pelo qual é possível estabelecer conexões de aprendizagens não somente entre múltiplos sistemas, mas extraterritorialmente, no caso dos sistemas políticos e do direito. As novas ordens formadas dentro da sociedade poderão ser estudadas de forma analítica e crítica dentro dessa metodologia.

Essas pontes como entrelaçamentos que servem a uma racionalidade transversal entre ordens jurídicas não são construídas de maneira permanente e estática no âmbito do transconstitucionalismo ${ }^{165}$. Um sistema jurídico exposto frequentemente às intromissões opera em um estado de corrupção. Reconhece por meio de suas normas que não pode resistir à pressão da política. $\mathrm{O}$ sistema se mantém simulando legalidade, ainda assim não renuncia à normatividade em geral $^{166}$.

\footnotetext{
${ }^{162}$ NEVES, Marcelo. Transconstitucionalismo. São Paulo: Martins Fontes, 2009, p. 34.

163 NEVES, Marcelo. Transconstitucionalismo. São Paulo: Martins Fontes, 2009, p. 34.

${ }^{164}$ NEVES, Marcelo. Transconstitucionalismo. São Paulo: Martins Fontes, 2009. p. 45.

165 NEVES, Marcelo. Transconstitucionalismo. São Paulo: Martins Fontes, 2009. p. 113.

${ }^{166}$ LUHMANN, Niklas. El derecho de la sociedad. Trad. Javier Torres Nafarrate. México: Universidade Iberoamericana/Colección Teoria Social. 2002.p. 137-8.
} 


\subsection{A Diplomacia Parlamentar: democratização e função}

Uma preocupação recorrente em nível internacional lato sensu ou extranacional é o nível de participação e representação no processo legislativo, na medida em que as legislações internacionais têm alcançado maior relevância, abrangência e incorporação doméstica nas últimas décadas. Para modificar essa tradicional lacuna das democracias nacionais em suas relações externas e do monopólio do Poder Executivo, seria necessário ter uma maior representação social.

Entende-se que a diplomacia parlamentar pode gradualmente realizar essa representação, uma vez que já conta com um poder difuso de legislar, fiscalizar e representar legitimamente a população no que se refere aos temas internacionais e a diferentes esferas de interesse. A diplomacia parlamentar pode ser um dos vetores para constitucionalizar os entrelaçamentos de ordens legislativas diferentes. É um dos poucos atores com essa capacidade.

Esse assunto é debatido na literatura em termos de déficit democrático e das demandas de inclusão da sociedade civil organizada. Organizações não governamentais, organizações internacionais ou associações de interesses particulares diversos são oferecidas como suposto remédio para a maioria das deficiências democráticas. A proposta da diplomacia parlamentar é diferenciada na medida em que inclui agentes eleitos, legitimados por um Estado e que fazem política (no sentido de Luhmann).

De tal perspectiva, surge o debate sobre a função da sociedade civil. Ela pode ter capacidade de cumprir papel importante na representação de interesses de coletividades, dado que as organizações internacionais não contam, em sua maioria, com parlamentos de qualquer ordem. Entretanto, a sociedade civil ainda não conta com a mesma accountability que as instituições estatais. Resultados desse nível são mais frequentes com intervenções de parlamentos, do judiciário, avaliações de especialistas e da mídia ${ }^{167}$.

A sociedade civil impõe um novo plano de representação, mas tem um distanciamento institucional da política. As noções de delegação, representação e, assim, legitimidade estruturam e limitam a autonomia entre os poderes de fazer lei, executar e interpretar. Ao contrário de uma diplomacia tradicional do Poder Executivo, e de forma distinta da sociedade

\footnotetext{
${ }^{167}$ SCHOLTE, Jan Aart. "Civil Society and Democratically Accountable Global Governance”. Government and Opposition - An International Journal of Comparative Politics, vol. 39, no. 4, 2004. p. 233.
} 
civil, a diplomacia parlamentar é necessariamente testada a cada novo ciclo eleitoral, de nova legitimação popular pelo voto.

A delegação é sempre limitada pelo modo de imposição legítimo, por emissores legítimos e por destinatários legítimos. Essa limitação coloca o princípio da limitação da autonomia do poder como condição especial para uma reelaboração da questão da soberania, que se torna um tipo de relação e não uma forma de independência ${ }^{168}$.

A eleição democrática funciona como um filtro de possíveis influências externas, excluindo a imposição imediata de interesses particularistas, que poderiam afetar o âmbito da política por desviá-la do interesse público. Assim, “o sufrágio universal, igual e secreto também objetiva assegurar a independência do eleitor em relação aos seus outros papéis sociais e, dessa forma, imunizar o procedimento eleitoral contra diferenças de status." ${ }^{169}$ Isso quer dizer, em tese, que as diferenças econômicas, políticas ou religiosas ficam suspensas na relação com o parlamentar, conferindo certo grau de autonomia na sua função.

A diplomacia parlamentar permite ser um ator multiangular na teoria dos sistemas no plano internacional e na circularidade sistêmica entre administração, poder stricto sensu, povo e esfera pública. Diferentemente de outros atores internacionais, como a sociedade civil organizada ou a diplomacia tradicional, a diplomacia parlamentar tem ao mesmo tempo: a autoridade política por ser parte da administração; a capacidade de negociação entre diferentes esferas do governo, partidos políticos, grupos de interesse, movimentos sociais, uma vez que também é incluída na política stricto sensu; o contato com a esfera pública, pois é eleita periodicamente; e a legitimidade em relação ao povo, pois precisa ser eleita.

Por isso, a diplomacia parlamentar poderá ter a capacidade de ser mais sensível ao povo constitucional ou esfera pública, sendo o fiel da balança do método transconstitucional: "eu posso ver o que o outro não pode". A diplomacia parlamentar seria capaz de trazer o alter para dentro da discussão do processo legislativo entre ordens ${ }^{170}$.

168 FERRAZ JUNIOR, Tercio Sampaio. Estudos de Filosofia do Direito: reflexões sobre o poder, a liberdade, a justiça e o direito. $2^{\text {a }}$ Ed. São Paulo: Atlas, 2003. p. 58-9.

${ }^{169}$ A inexistência de eleições efetivamente democráticas, nas condições atuais, relaciona-se estreitamente com tendências ideológicas que desconhecem a pluralidade contraditória de valores, interesses e expectativas, como também com a prevalência de interesses de grupos privilegiados. In: NEVES, Marcelo. Entre Têmis e Leviatã: uma relação difícil: o Estado Democrático de Direito a partir e além de Luhmann e Habermas. São Paulo: Martins Fontes, 2006. p. 101; p.104

${ }^{170} \mathrm{O}$ transconstitucionalismo depende de um método que não se concentre em uma identidade cega. Ordens jurídicas - ou políticas - isoladas são levadas, normalmente, a considerar em primeiro plano a sua identidade, pois, caso contrário, diluem-se. Assim, não há um lócus ou pressuposto exclusivo para as decisões de problemas constitucionais. A própria identidade de cada observador define o seu ponto cego, o observador não pode ver em virtude de sua posição ou perspectiva de posição. Eu vejo aquilo que tu não vês, e o 
Essa característica tem dois lados. Enquanto a sociedade civil tem uma pauta definida, pois normalmente suas entidades estão ligadas a algum grupo ou tema específico, os parlamentares têm potencial para transmitir as especificidades de cada povo ou local no âmbito internacional. Contudo, a democracia parlamentar também pode estar mais suscetível a corrupção, diferindo nisso da diplomacia do Poder Executivo, que habitualmente atua como um ator único, com uma pauta definida.

A conceituação dogmática da diplomacia parlamentar não possui um sentido único na literatura de relações internacionais ou de direito internacional. Isso se deve a duas razões principais: a escassa produção acadêmica sobre o assunto e o aumento da variedade de práticas que são classificadas como diplomacia parlamentar. Além disso, nunca houve uma sistematização apropriada aos usos do termo, apenas tentativas esparsas de classificação. A maior parte da literatura se propõe a descrever as atividades e a destacar fatos novos sobre o tema, como emergência de parlamentos ou encontros parlamentares.

A diplomacia parlamentar se distingue da diplomacia clássica, composta por delegação do Poder Executivo e da paradiplomacia. É diferente da diplomacia clássica na medida em que envolve, necessariamente, o conceito de parlamento, em métodos ou representação. Além disso, a diplomacia parlamentar não é a mesma tarefa parlamentar da política externa e de defesa, embora as duas estejam ligadas ${ }^{171}$.

Também não é o mesmo que a paradiplomacia, a qual se preocupa prioritariamente com a atração dos entes subnacionais, tradicionalmente desautorizados ou despersonalizados internacionalmente para determinados atos, embora seja amplamente estudada ${ }^{172}$.

\footnotetext{
contrário, o ponto cego de um observador pode ser visto pelo outro. Nesse sentido, pode-se afirmar que o transconstitucionalismo implica o reconhecimento dos limites de observação de uma determinada ordem, que admite a alternativa: o ponto cego, o outro o pode ver. In: NEVES, Marcelo. Transconstitucionalismo. São Paulo: Martins Fontes, 2009. pp. 243 e seguintes.

${ }^{171}$ STAVRIDIS, Stelios. "Parliamentary Diplomacy": some preliminary findings. Jean Monnet Working Papers in Comparative and International Politics. November 2002 - JMWP n 48.

${ }_{172}$ A paradiplomacia pode ser definida como o envolvimento de governo subnacional nas relações internacionais, por meio do estabelecimento de contatos, formais e informais, permanentes ou provisórios ad hoc, com entidades estrangeiras públicas ou privadas, objetivando promover resultados socioeconômicos ou políticos, bem como qualquer outra dimensão externa de sua própria competência constitucional. Embora bastante contestado, o conceito de paradiplomacia não impossibilita a existência de outras formas de participação subnacional no processo da política externa, mais diretamente ligado ao departamento de relações exteriores de governos centrais, como a assim chamada diplomacia federativa. Também não impede o papel cada vez maior dos governos subnacionais nas estruturas de multicamadas para a governança regional ou mundial In: PRIETO, Noé Cornago. O outro lado do novo regionalismo pós-soviético e da ÁsiaPacífico. In: VIGEVANI, Tullo (Org.). A dimensão subnacional e as relações internacionais. São Paulo: Unesp, 2004, p. 252-252. Principais Referências: VENTURA, D. F. L.; FONSECA, M. G. . Posibilidades y límites a la participación de los entes subnacional es en la política exterior de Brasil y en los procesos de integración regional. Revista CIDOB d'Afers Internacionals v. 99, p. 55-73, 2012.
} 
“Contrariamente à existência de uma bem desenvolvida literatura em paradiplomacia, há uma pequena, limitada, mas esperançosa literatura emergente em diplomacia parlamentar." 173

A polissemia não é imotivada. Além de possuir uma conotação imprecisa, esse signo tem uma variação significativa no tempo e uma multiplicação de fatos correlatos - como a pluralização de atividades parlamentares extranacionais - que acabaram sendo amplamente designados como diplomacia parlamentar. Ademais, existe uma defasagem acadêmica sobre o assunto $^{174}$. Embora o tema possa colaborar para o debate sobre participação democrática nas ordens internacionais, a diplomacia parlamentar tem sido ignorada por acadêmicos de relações internacionais, principalmente pelas duas principais correntes teóricas, neorrealista e neoinstitucionalista ${ }^{175}$.

É notável mencionar que o fenômeno da nova diplomacia parlamentar é recente, complexo e carrega a combinação do selo de desconfiança sobre o direito internacional e uma prejudicada reputação dos parlamentares de modo geral. ${ }^{176}$ Ele é também recente, pois, embora originado das discussões sobre a Liga das Nações e Assembleia Geral da ONU, é apenas com a terceira onda democrática, no sentido de Huntington ${ }^{177}$, com o renascimento democrático na América latina e na Europa do Leste, que percebemos um aumento significativo de países democráticos, com parlamentos legítimos. "Nos últimos anos, os legisladores têm assumido um papel proeminente na gestão dos assuntos públicos, como resultado do processo de redemocratização. O fato de que 181 dos 192 Estados existentes tenha Parlamento é prova de sua crescente importância." ${ }^{178}$ Ou seja, a partir do momento em

\footnotetext{
${ }^{173}$ STAVRIDIS, Stelios. ParliamentaryDiplomacy. Any Lessons for regional parliaments? p. 3

174 Esse argumento está presente na maioria da restrita literatura sobre o tema: STAVRIDIS, Stelios. Parliamentary Diplomacy Any Lessons for regional parliaments? Paregi. Bordeaux, 2006. RAY, R. Parliamentary Diplomacy. New Delhi: Chand. 1991; RUSK, D. Parliamentary Diplomacy - Debate vs. Negotiation, World Affairs Interpreter.1955, 26: 121-38. GÖTZ, Norbert. On the Origins of 'Parliamentary Diplomacy' Scandinavian 'Bloc Politics' and Delegation Policy in the League of Nations Cooperation and Conflict: Journal of the Nordic International Studies Association Vol. 40(3): 263-279. 2005.

${ }^{175}$ Robert Götz afirma que as disciplinas de história da diplomacia e relações internacionais poderiam incluir esse debate, problematizando, dessa forma, a complexidade doméstica da elaboração de política externa e fazendo com que esse tema fosse mais presente nas discussões. In: GÖTZ, Norbert. On the Origins of 'Parliamentary Diplomacy' Scandinavian 'Bloc Politics' and Delegation Policy in the League of Nations Cooperation and Conflict: Journal of the Nordic International Studies Association Vol. 40(3): $263-279$. 2005.

${ }^{176}$ A utilização dessa expressão pela primeira vez é atribuída ao Secretário Americano de Estado, Dean Rusk, que cunhou o verbo referindo-se a forma de diplomacia nas Nações Unidas em 1955. In: STAVRIDIS, Stelios; PACE, Roderick. Regional Parliaments in the Euro-Mediterranean Region: does it amount to Integration? Garnet, Bordeaux, 24 March, 2010.

${ }^{177}$ HUNTINGTON, Samuel. The third wave: democratization in the late twentieth century. University of Oklahoma Press, 1991.

178 JIMENEZ, Carlos. Diplomacia parlamentar. Diplomacia Parlamentar - Uma Contribuição ao Debate. Instituto Universitas. Brasília-DF: DGrau Multimídia Ltda, 2008.
} 
que se nota um aumento no número de parlamentos legítimos em Estados de Direito, há uma intensificação no debate de seu conceito e atuação da diplomacia parlamentar

A gênese da ideia de diplomacia parlamentar está na diplomacia multilateral, relacionada às negociações na Ligas das Nações e, depois, nas Nações Unidas, no estabelecimento de redes multilaterais, por seus métodos e os agentes diplomáticos inerentes a eles ${ }^{179}$. Naquele momento, a diplomacia parlamentar foi estabelecida como um conceito que estava relacionado com as negociações multilaterais especificamente pela institucionalização, regras de procedimento, o debate público e a votação do projeto de resolução daquele período histórico $^{180}$. Ainda hoje, a Liga das Nações e a ONU continuam a ser casos de diplomacia parlamentar, pela importância de organizações de alcance universal e também por sua tensão entre diplomacia parlamentar e diplomacia tradicional ${ }^{181}$.

Naquele momento histórico, a noção de diplomacia caracterizava-se exclusivamente por imitar procedimentos parlamentares em órgãos deliberativos, com a composição de diplomatas públicos de carreira, agentes do Poder Executivo ou membros do Ministério de Relações Exteriores, ou seus convidados. Essa noção de diplomacia parlamentar será nomeada e detalhada como diplomacia parlamentar não-eleita, nos itens subsequentes.

Com efeito, a diplomacia parlamentar foi primeiramente conceituada de acordo com Rusk, como um conceito que descrevia essas negociações multilaterais caracterizadas por institucionalização, regras de procedimento, debate público e votação em projetos de resoluções ${ }^{182}$. Mas é interessante perceber que, nesse primeiro conceito, ainda não há alusão aos possíveis tipos de atores envolvidos, sua legitimidade, nem mesmo os diferentes locus de fala, isto é, as naturezas variadas de parlamentos.

Entretanto, o conceito de diplomacia parlamentar ampliou seu campo semântico ao abarcar situações novas no contexto internacional, abrangendo uma série de atividades que, por vezes, vão além das paredes do Parlamento, além das constituições e regimentos. "Surge como atividade direta do Legislativo nas decisões internacionais e como resposta ao processo

179 GÖTZ, Norbert. On the Origins of 'Parliamentary Diplomacy' Scandinavian 'Bloc Politics' and Delegation Policy in the League of Nations Cooperation and Conflict: Journal of the Nordic International Studies Association Vol. 40(3): 263-279. 2005. p. 275.

${ }^{180}$ RUSK, D. Parliamentary Diplomacy - Debate vs. Negotiation, World Affairs Interpreter. 1955. 12138.p. 122.

181 GÖTZ, Norbert, 2005. 275.

182 RUSK, D. Parliamentary Diplomacy - Debate vs. Negotiation, World Affairs Interpreter. 1955, 26: 121-38. 
de globalização multidimensional que estimulou e estimula mudanças nas estruturas e nas instituições na órbita internacional, refletindo mudanças internas dos países." 183

Assim, a diplomacia parlamentar gradualmente começa a ser relacionada com o desempenho de parlamentares no papel de diplomatas, ou com a influência de Assembleias Parlamentares na formulação da política externa. ${ }^{184}$ A diplomacia parlamentar não desempenha a mesma tarefa que a diplomacia clássica, mas ambas podem estar eventualmente relacionadas.

\begin{abstract}
A importância da diplomacia parlamentar é articular o Legislativo como protagonista da política externa de seu país, retirando a exclusividade dessa competência do Poder Executivo, visando a fortalecer as relações com os organismos internacionais e interparlamentares, a representar e a estabelecer alianças com a sociedade civil organizada, a fim de advogar e decidir sobre interesses sociais, culturais e comerciais, entre outros. ${ }^{185}$
\end{abstract}

Como protagonista, a diplomacia parlamentar pode tornar-se interveniente nos episódios de discussões em torno de produção de normas internacionais, fazendo com que o processo seja mais inclusivo e legítimo.

$\mathrm{O}$ acesso privilegiado a informações e a instituições ao Executivo criado em torno do amálgama da prerrogativa de “interesse nacional” ou de delegação constitucional não se coaduna com os princípios democráticos materiais de todo sentido material e simbólico da noção de constituição ${ }^{186}$. Por isso, em tese, a diplomacia parlamentar pode ser um ator protagonista e atuante nas relações internacionais, democratizando estruturas e trazendo a público um debate que não interessa apenas à elite intelectual ou política, mas a todos.

\footnotetext{
183 FRANCO, Giuliana Silva. Diplomacia parlamentar no Brasil: Participação Direta nas Decisões Internacionais. In: Diplomacia Parlamentar - Uma Contribuição ao Debate. Instituto Universitas. BrasíliaDF: DGrau Multimídia Ltda, 2008.

${ }^{184}$ RAY, R. Parliamentary Diplomacy. New Delhi: Chand. 1991, p. 2.

185 FRANCO, Giuliana Silva. Diplomacia parlamentar no Brasil: Participação Direta nas Decisões Internacionais. In: Diplomacia Parlamentar - Uma Contribuição ao Debate. Instituto Universitas. BrasíliaDF: DGrau Multimídia Ltda, 2008.

${ }^{186}$ Interesse nacional foi um dos três argumentos utilizados no Parecer do Itamaraty para a negativa ao Projeto de Lei 5.974/1982 que pretendia democratizar as missões diplomáticas brasileiras. In: FRANCHININETTO, M. Projeto de Lei n. ${ }^{\circ}$ 5.974/1982, que dispõe sobre a participação de representantes oposicionistas em missão oficial brasileira no exterior. Brasília, 1982. In: MEDEIROS, Antônio Paulo Cachapuz (Org.) Pareceres dos Consultores Jurídicos do Itamaraty. Vol VIII (1972-1984). Brasília: Senado Federal, 2004. pp. 358-361. A respeito da constituição simbólica: no Brasil, a constitucionalização simbólica de orientação social democrática é restabelecida e fortificada com o texto constitucional de 1988. O contexto social da Constituição apontava para limites intransponíveis a sua concretização generalizada, e quanto mais as relações reais de poder se afastavam do modelo constitucional democrático, tanto mais radical era o discurso constitucionalista. Dessa forma o problema surge no plano da concretização constitucional. A prática política e o contexto social favorecem uma concretização restrita e excludente dos dispositivos constitucionais. In: NEVES, Marcelo. Constitucionalização Simbólica. $2^{\mathrm{a}}$ Ed. São Paulo: WMF Martins Fontes, 2007. P. 184.
} 
Um aspecto destacado é a grande variedade de temas discutidos pela diplomacia parlamentar. Alguns parlamentares cobrem todas as questões internacionais, enquanto outros são mais voltados especificamente para os direitos humanos, defesa, etc. Por exemplo, da perspectiva de diplomacia parlamentar eleita de função fiscalizadora, as Comissões de Direitos Humanos mantêm um diálogo e uma atuação constantes junto a organismos de proteção de minorias, como no caso da Comissão Interamericana de Direitos Humanos e/ou outros órgãos internacionais ou movimentos sociais, como aconteceu, por exemplo, no caso Damião Ximenes Lopes. Outros parlamentares estão interessados em um aspecto específico, por exemplo a integração regional, como é o caso daqueles que são indicados para compor o Parlamento do Mercosul, ou as reuniões conjuntas, como a Assembleia Parlamentar EuroLatino-Americana $\left(\right.$ EUROLAT) ${ }^{187}$.

Uma série de eventos combinados serve para enfatizar essa noção: o aumento no número de Estados democratizados, o aumento de parlamentos extranacionais (supranacionais, transnacionais, internacionais); crescimento das relações e encontros de reuniões de amizade e negociação de parlamentares; e, por fim, a tecnologia da informação.

O aumento do número de estados democráticos na América latina e no leste europeu incrementou o número de parlamentos no mundo. $\mathrm{O}$ avanço da comunicação fortaleceu os interesses dos cidadãos em muitos Estados para saber o que está acontecendo no mundo. A pressão de parlamentares para responder a essas reivindicações aumentou a intrusão democrática de parlamentares na política externa ${ }^{188}$.

Aliado à democratização dos países, os órgãos transnacionais lato sensu e a história de alguns parlamentos regionais (supranacionais) também colaboram para o desenvolvimento da diplomacia parlamentar. "Há uma proliferação de órgãos parlamentares nacionais e transnacionais com papel ativo nas questões internacionais. Esse importante fenômeno representa uma forma emergente de diplomacia pública, chamada de diplomacia parlamentar." 189

A força crescente do Parlamento Europeu, assim como a institucionalização da União Europeia, serviu de espelho a outras regiões, encorajando a emergência de novos parlamentos, ainda que nenhum outro parlamento regional tenha poderes semelhantes aos do Europeu. Assim, nota-se a abundância de evidências empíricas de um crescente protagonismo dos

\footnotetext{
${ }^{187}$ Esses casos serão ampliados e debatidos no decorrer do capítulo.

${ }^{188}$ STAVRIDIS, Stelios; PACE, Roderick. Regional Parliaments in the Euro-Mediterranean Region: does it amount to Integration? Garnet, Bordeaux, 24 March, 2010.

${ }^{189}$ STAVRIDIS, Stelios. Parliamentary Diplomacy. Any Lessons for regional parliaments? p. 3.
} 
parlamentares nos assuntos mundiais, bem como um crescimento significativo no número de órgãos parlamentares transnacionais ${ }^{190}$.

Por outro lado, a tecnologia da informação tornou o acesso aos representantes e até mesmo à política externa mais fácil. $\mathrm{O}$ crescimento em comunicação fortaleceu os interesses dos cidadãos em muitos Estados para perceber o que está acontecendo no mundo ${ }^{191}$.

Contudo, as instâncias que evocam a legitimidade parlamentar nas - ou para as organizações internacionais são pouco conhecidas. Paul Bacot procurou compreender a importância dos parlamentos internacionais principalmente na área de segurança internacional. Para isso, buscou o sentido etimológico de certas palavras que fazem referência aos parlamentos e assembleias no contexto internacional, promovendo um estudo quantitativo sobre discursos em organismos internacionais ${ }^{192}$.

Os resultados demonstram que há uma multiplicidade de referências aos termos: parlamentar, parlamento, interparlamentar, assembleia, congresso, conferência, que são utilizados sem a devida distinção. Cerca de um terço dos organismos estudados por ele correspondem a uma instância parlamentar mais ou menos efetiva. Dentro desse aglomerado de entes "parlamentares", a maior constatação é a quase onipresença da palavra parlamentar. Os nomes "parlamento", "parlamentar" (substantivo e adjetivo) e o morfema "-parlamentar" no adjetivo "interparlamentar" figuram na denominação de 5 a cada 6 organizações que contam com esse tipo de órgão ${ }^{193}$.

Assim, há uma variedade de órgãos com distintas representações, finalidades ou poderes que se nomeiam como parlamentares, por exemplo: assembleias, associações, comitês, conselhos, diálogos, sindicatos, e até mesmo parlamentos de ordens extranacionais múltiplas. Há também uma série de organizações e de outras associações que fazem uso do termo parlamento, com sentido voltado para reunião sobre algum tema ou/e uma categoria, como, por exemplo, o Parlamento dos Bálcãs, que agrupa estudantes, acadêmicos e empresários da região, ou o Parlamento Europeu dos Jovens, uma organização que promove a problematização de temas entre os jovens europeus ${ }^{194}$.

\footnotetext{
${ }^{190}$ STAVRIDIS, Stelios. "Parliamentary Diplomacy": some preliminary findings. Jean Monnet Working Papers in Comparative and International Politics.November 2002 - JMWP n ${ }^{\circ} 48$.

${ }^{191}$ STAVRIDIS, Stelios; PACE, Roderick. Regional Parliaments in the Euro-Mediterranean Region: does it amount to Integration? Garnet, Bordeaux, 24 March, 2010.

${ }^{192}$ A lista de organismos é imensa e não cabe aqui a simples listagem. Para averiguar a lista de OI: BACOT, Paul. Parlement, Région, Securité, Existence et dénomination des institutions parlamentaires internationales. In : HASSAN-YARI, Houchang ; OUSMAN, Abdelkérim. Régionalisme et sécurité internationale. Bruxelas :Bruylant, 2009.

${ }^{193}$ BACOT, Paul, 2009. Op. Cit. p.30.

${ }^{194}$ STAVRIDIS, Stelios. "Parliamentary Diplomacy": some preliminary findings. Jean Monnet Working Papers in Comparative and International Politics. November 2002 - JMWP n 48.
} 


\subsubsection{Contornos para uma classificação}

Com efeito, o conceito parlamentar coligado à diplomacia esvazia-se na difusão policontextural própria de um instituo que ganha força com a tecnologia e com a contemporaneidade. Essa confusão, em geral devida ao desconhecimento, agrega desconfiança à força, à efetividade, da diplomacia parlamentar como fonte de poder, fonte de direito internacional e ator num processo legislativo de ordens jurídicas entrelaçadas. Para se afastar desse lado negativo, a literatura tem dado passos iniciais na direção de uma forma de classificação que consiga sair do paradoxo da desordem, propondo uma forma de discurso.

De acordo com Stavridis, é possível agrupá-los sob o rótulo geral de atividades e ações que órgãos parlamentares e seus membros têm nas relações internacionais. Uma lista inicial proposta pelo autor abrigaria as seguintes atividades: missões parlamentares no exterior e participação em órgãos parlamentares transnacionais; visitas de delegações parlamentares e de outros deputados de parlamentos e outras instituições (nacionais ou transnacionais); questionamentos (escritos e orais), relatórios e outros estudos sobre assuntos externos que têm lugar dentro de uma instância parlamentar; atividades dos órgãos parlamentares transnacionais; participação parlamentar no acompanhamento das eleições em países terceiros $^{195}$.

Já Norbert Götz distingue a diplomacia parlamentar em duas formas: a primeira se refere a métodos específicos de tomada de decisão e a segunda se refere a um tipo particular de ator, que não está ligado a outro por nenhum meio estrito ${ }^{196}$. Na primeira forma, a diplomacia parlamentar seria exercida normalmente pela diplomacia pública (clássica) multilateral em assembleias mundiais, como na assembleia geral da ONU ou em fóruns globais, como os World Summits. Na segunda forma, legisladores e legislaturas podem estar envolvidos em relações diplomáticas sob condições que não se assemelham a procedimentos parlamentares.

\footnotetext{
195 STAVRIDIS, Stelios. "Parliamentary Diplomacy": some preliminary findings. Jean Monnet Working Papers in Comparative and International Politics. $N^{\circ}$ 48. 2002.

196 GÖTZ, Norbert. On the Origins of 'Parliamentary Diplomacy' Scandinavian 'Bloc Politics' and Delegation Policy in the League of Nations Cooperation and Conflict: Journal of the Nordic International Studies Association Vol. 40(3), 2005 263-279. 264.
} 
Embora a primeira sistematização pareça bastante inclusiva, ela deixa de lado o primeiro sentido da diplomacia parlamentar, assim como um dos aspectos mais recorrentes, a diplomacia parlamentar estatal. Por outro lado, a diferenciação de Götz se aproveita das noções de ator e ação, mas não dá lugar à diplomacia parlamentar regional e não aprofunda o caráter democrático que a diplomacia parlamentar pode acrescentar, não distingue as variadas relações entre ordens diferentes, nem mesmo os poderes distintos que cada ator poderá ter.

Além dessas formas de classificação, atores/procedimentos, há uma clara evidência de vasos comunicantes entre a maioria destes organismos transnacionais, se não entre todos eles, e parlamentar nacional, como destaca Stavridis ${ }^{197}$. A expressão vasos comunicantes é uma noção muito aproximada dos entrelaçamentos de ordens legislativas trabalhadas.

Diante de uma série de tentativas de classificação, há clivagens por ator, parlamento, métodos ou atividades. Não se materializa nenhuma forma que seja, ao mesmo tempo, totalizante e tenha um critério justificado. Assim, a partir da avaliação bibliográfica, propõese um arquétipo que seja compatível com o transconstitucionalismo e a teoria dos sistemas sociais autopoiéticos.

A diplomacia parlamentar como conceito é um ator eleito (parlamentar) ou não-eleito (diplomacia pública ou do Executivo) que detém poderes legislativos, fiscalizadores ou representativos dentro de um lócus com entrelaçamento de ordem extranacional.

Portanto, os dois critérios da sistematização serão: democrático e divisão de poderes. O primeiro critério de distinção, partindo de uma órbita constitucional, é o critério democrático. A partir do momento em que o Estado moderno adere ao sistema democrático de governo, o código governo/oposição institui que ocorram eleições periódicas com possibilidade de mudança de governo. Esse critério é propício a uma oposição apta a criticar, fiscalizar e tentar buscar maior sucesso nas eleições seguintes. Podemos perceber uma motivação inerte a essa diferenciação. Assim, o critério democrático será a diferença eleito/não-eleito.

A legitimidade democrática reflete tanto na eleição do executivo quanto na eleição dos legisladores, especialmente quando há partidos disciplinados. Isso traz à tona a pergunta de quem deve falar em última ratio em nome do povo, o legislativo ou o executivo. $\mathrm{O}$ tempo de mandato é sempre pré-determinado, fazendo com que a sociedade e os políticos devam se adequar ao ritmo de eleições ${ }^{198}$.

\footnotetext{
${ }^{197}$ STAVRIDIS Stelios, 2002. Op. Cit.

198 LINZ, Juan. Presidencialismo ou Parlamentarismo: Faz alguma diferença? LAMOUNIER, Bolívar et al. (Org.) A Opção Parlamentarista, São Paulo: Sumaré, p.61-120. 1991. Em vários estudos
} 
Democracia é um governo pro tempore, um governo no qual o eleitorado, em intervalos regulares, pode exigir uma prestação de contas daqueles que governam e impor uma mudança. Aqui surge um paradoxo, pois, ao mesmo tempo que a limitação de tempo para qualquer governo entre uma eleição e outra talvez seja a maior garantia contra a onipotência e o abuso de poder, pois todos os governos desejam se perpetuar no poder, um líder excelente não poderá concorrer ao cargo, tendo em vista a limitação de re-eleição ou limitação do termo $^{199}$.

A eleição constante e periódica de representantes é uma característica indissociável da democracia. "O que esta temporalidade transcendente assinala é que o povo atual - o corpo eleitoral do momento - nunca passa do representante momentâneo e transitório do povo perpétuo, verdadeiro titular da soberania.",200

A democracia é o regime que tira autoridade do apoio renovado do povo. Mas uma tensão não parou de opor esse ideal democrático à realidade do regime representativo, que pressupõe que o direito de palavra seja delegado pelo povo aos representantes, exceto durante o breve instante das consultas eleitorais ${ }^{201}$.

O critério para a diplomacia parlamentar eleita inclui todos os parlamentares que sejam eleitos periodicamente por alguma ordem legislativa, seja estatal ou supranacional: isto é, parlamentares nacionais, regionais que desempenhem todo tipo de poderes em reuniões, assembleias, parlamentos, entre parlamentos no exterior ou no seu próprio parlamento.

Esse critério se justifica porque reduz, ou atenua o déficit democrático no processo legislativo. Quanto maior legitimidade dos atores presentes no debate legislativo, maior a possibilidade de despontar demandas que gerem conflito governo/oposição, desfazendo a ficção do estado como ator único dentro de um debate na seara internacional.

Praticamente todas as atividades dos parlamentos nacionais tornaram-se cada vez mais internacionalizadas, não apenas os direitos humanos ou a defesa. Os assuntos antes estatais agora estão entrelaçados, como as comissões técnicas agrícolas, de educação ou saúde. A globalização da sociedade tanto fortaleceu este desenvolvimento quanto implicou o aumento

neoinstitucinalistas, utiliza-se uma definição de democracia minimalista: democracia é um regime no qual aqueles que governam são selecionados por meio de eleições disputadas. In: PRZEWORSKI, Adam, et. al, Economic development and political regimes. Cambridge: Cambridge University Press, 2003.

${ }^{199}$ LINZ, Juan. Presidencialismo ou Parlamentarismo: Faz alguma diferença? LAMOUNIER, Bolívar et al. (Org.) A Opção Parlamentarista, São Paulo: Sumaré, p.61-120. 1991.

${ }^{200}$ OST, François. O tempo do Direito. Tradução Maria Fernanda Oliveira. Lisboa: Instituto Piaget. 1999. p. 263.

${ }^{201}$ OST, François. Op. Cit.1999. p. 260. 
no número de parlamentares nas atividades de instituições como o Banco Mundial, o FMI ou a Organização Mundial do Comércio ${ }^{202}$.

Esse critério inclui também o parlamento supranacional da União Europeia e o regional do MERCOSUL. As atividades e papéis desses parlamentos não podem ser rapidamente comparados com parlamentos nacionais, mas podemos observar que eles cumprem certas funções. O único parlamento que elege seus representantes por sufrágio universal direto é o Parlamento Europeu, desde 1979. O Parlamento do Mercosul adiou suas eleições diretas para 2020, sendo que o Paraguai ainda é o único país que realiza tal procedimento: o restante de seus membros permanece sendo indicado pelos parlamentos nacionais, ou seja, são eleitos para o pleno nacional, não para o regional ${ }^{203}$.

Esse critério da diplomacia parlamentar eleita/não-eleita inclui basicamente esses dois tipos de atores: parlamentares nacionais e supranacionais (regionais) ou diplomatas do Poder Executivo. Contudo, esse critério recebe uma segunda distinção, pelas funções que cada uma dessas reuniões, assembleias, parlamentos poderão ter: legislativa, fiscalizadora e/ou diplomática.

Esse segundo critério leva em consideração que, constitucionalmente, a maioria das casas parlamentares conta com três funções: Legislativa, Fiscalização e Orçamentária. ${ }^{204}$ As diferentes funções da instituição dependem do estágio e das modalidades de intervenção ${ }^{205}$. Entretanto, nas relações internacionais, o poder orçamentário ainda é associado a um território específico. Com a exceção do Parlamento Europeu e da Assembleia Geral da ONU, nenhum parlamento extranacional conta com essa especificidade. Ademais, poderíamos considerar que esse critério está incluído dentro do Poder Legislativo.

Ao contrário, uma das suas mais importantes funções é a própria diplomacia dessas relações. Portanto, a terceira função da diplomacia parlamentar é a diplomacia, que

\footnotetext{
${ }^{202}$ STAVRIDIS, Stelios. "Parliamentary Diplomacy": some preliminary findings. Jean Monnet Working Papers in Comparative and International Politics. November 2002 - JMWP n ${ }^{\circ} 48$.

${ }^{203} \mathrm{O}$ adiamento foi proposto pelo deputado brasileiro Dr. Rosinha (PT-PR), no dia 02/12/2013, mas ainda não foi aprovado pelo Conselho do Mercosul. Assim, está previsto para dia 31 de dezembro de 2020 o prazo para que os cinco países membros do bloco (Brasil, Argentina, Uruguai, Paraguai e Venezuela) escolham seus representantes na instituição por eleições diretas. In: CÂMARA DOS DEPUTADOS. Agência Câmara Notícias. Parlasul adia eleições diretas de parlamentares do Mercosul para 2020. Disponível em <http://www2.camara.leg.br/camaranoticias/noticias/RELACOES-EXTERIORES/458455-PARLASULADIA-ELEICOES-DIRETAS-DE-PARLAMENTARES-DO-MERCOSUL-PARA-2020.html> Acesso em $4 / 12 / 13$

${ }^{204}$ Há variadas abordagens das funções do Parlamento. Alguns autores as dividem em representativa, legislativa, de legitimação e de controle. Ver: SILVA, José Afonso da. Processo Constitucional de Formação das Leis. $2^{\mathrm{a}}$ ed. São Paulo: Malheiros, 2006. BERCOVICI, G.Dilemas do estado federal brasileiro. Porto Alegre: Livraria do Advogado, 2004.;.

${ }^{205}$ DRI, Clarissa. As funções do parlamento entre o Estado-nação e a integração regional: esgotamento orgânico ou adaptação institucional? Revista de Ciências Humanas. N. 39. Florianópolis, EDUFSC, p. 8398, abril de 2006. P. 86.
} 
geralmente é conceituada "como um processo de comunicação do Estado com o outro, numa tentativa de levar a compreensão de valores e ideais da nação, instituições e cultura, bem como as metas e as políticas nacionais." ${ }^{206}$ A função diplomática, na diplomacia parlamentar, abrange a função socializante e negociante das relações diplomáticas, com limitado poder legislativo ou de controle.

Embora as funções se espelhem em poderes clássicos do constitucionalismo, é necessário compreender as limitações e possibilidades especiais principalmente, levando em consideração o objetivo de vasculhar as ordens legislativas entrelaçadas. Para efeito de esclarecimento da sistematização, esta será explorada e detalhada a seguir.

\subsubsection{Diplomacia Parlamentar Não-Eleita}

A diplomacia parlamentar não-eleita tem como ideia base a diplomacia multilateral. Esse tipo de diplomacia parlamentar se caracteriza pela diplomacia pública (clássica), em que há regras de procedimento, com o debate público e regras sobre votação parlamentar para aprovação dos resultados das suas atividades. Dessa forma, a diplomacia parlamentar é exercida no âmbito de organismos internacionais com constituições ou estatutos que irão prever a sua formação representativa, forma de atuação e competências.

A primeira conceituação da noção histórica de diplomacia parlamentar é associada à diplomacia multilateral ${ }^{207}$, mais precisamente, à diplomacia multilateral (pública) das negociações da Liga das Nações e das Nações Unidas, no início da construção de redes multilaterais, por seus métodos e os agentes diplomáticos inerentes a eles. Tanto nas Nações Unidas como na Liga das Nações, que poderiam ser consideradas como o que há de mais próximo de um parlamento mundial, o conceito deve ser entendido como analogia aos métodos e a órgãos legislativos. ${ }^{208}$

\footnotetext{
206 TUCH, Hans. Communicating With the World: US Public Diplomacy Overseas. Nova Iorque: StMartin's Press, 1990., p. 3.

${ }^{207}$ Por esse motivo, o primeiro conceito de diplomacia parlamentar será de Rusk, ainda em 1955, definindo-a como "negociações multilaterais caracterizadas por institucionalização, regras de procedimento, debate público e votação em projetos de resoluções." In: RUSK, D. Parliamentary Diplomacy - Debate vs. Negotiation, World Affairs Interpreter.1955, 26: p.127.

208 "A ideia de uma assembleia parlamentar mundial, na qual cidadãos do mundo seriam representados e se veria reconhecido o poder de legiferar em escalar planetária, ela é ainda utópica neste fim de século XX." In: DELMAS-MARTY, Mireille. Três Desafios para um Direito Mundial. Tradução Fauzi Hassan Choukr. Rio de Janeiro: Editora Lumen Juris, 2003. P. 167.
} 
A criação de órgãos deliberativos internacionais trouxe consigo a experiência de seus respectivos parlamentos nacionais e o seu nível de funcionamento para o âmbito da diplomacia multilateral. "Essa diplomacia trouxe também certos aspectos do parlamentarismo interno, notadamente o nível de trabalho das organizações e dos métodos de negociação."209

Assim, a Liga das Nações se torna a primeira, embora imperfeita, expressão do novo espírito da diplomacia por conferência, e seus órgãos se assemelhavam muito à própria ONU. Esse é o momento em que surge um novo sistema de relações internacionais, advogando princípios de universalismo, multilateralismo, diplomacia aberta, soluções conflituosas de paz e segurança comum ${ }^{210}$.

A diplomacia parlamentar, nesse caso, fica limitada às competências das organizações que estão a servir, isto é, o processo parlamentar constituído por cada um desses órgãos. Esses órgãos intergovernamentais serão compostos de representantes de Estados obedientes às instruções de seu governo. "Esses órgãos são o lugar de negociações diplomáticas tradicionais, onde seus interesses particulares (estatais) se confrontam.",211

A literatura de internacional law-making trata esse assunto com atenção voltada para os papéis de organizações internacionais nesse processo, a inclusão de atores da sociedade civil e a (in)eficácia das normas produzidas nesses processos. O objetivo é afastar-se dessas análises e voltar-se para a relação de diplomacia parlamentar não-eleita ${ }^{212}$.

A Assembleia Geral da ONU será usada como exemplo desse tipo de diplomacia parlamentar. Essa forma de diplomacia parlamentar caracteriza-se por mimetizar os procedimentos parlamentares em órgãos deliberativos. Contudo, a sua composição é de diplomatas públicos, agentes do Poder Executivo ou membros do Ministério de Relações Exteriores. A delegação de cada Estado-membro, composta de no máximo cinco representantes, tem o dever de demonstrar a carta de poderes emanados do Chefe de Estado, Chefe de Governo ou do Ministro das Relações Exteriores ${ }^{213}$.

\footnotetext{
${ }^{209}$ DORMOY, Daniel. Droit des organisations internationales. Paris: Dalloz, 1995.

${ }^{210}$ GÖTZ, Norbert, 2005. 267.

${ }^{211}$ DORMOY, Daniel. Droit des organisations internationales. Paris: Dalloz, 1995.

212 Tradução aproximada para processo legislativo internacional. Ver: BOYLE, Alan E. CHINKIN, C. M. The making of international law. Oxford University Press, 2007.; GREWE, Wihelm, The Epochs of International Law. Berlin: Walter de Gruyter, 2000. ALVAREZ, José. E. International Organizations as Law-Makers. New York: Oxford University Press, 2005. SHAW, Malcolm. International Law. Cambridge: University Press, 2008.

${ }^{213}$ Art. 25: A delegação de um Estado-Membro consiste no máximo de cinco representantes e cinco suplentes e assessores, técnicos, especialistas e pessoas com estatuto semelhante que venha a ser exigido pela Delegação. Art. 27: As credenciais dos representantes e os nomes dos membros de uma delegação serão submetidos ao Secretário-Geral, se possível, pelo menos, uma semana antes da abertura da sessão. A carta de poderes deve ser emitida pelo Chefe de Estado ou de Governo ou pelo Ministro dos Negócios Estrangeiros.
} 
$\mathrm{Na}$ Assembleia Geral e em outras organizações internacionais, seus resultados sobre certa matéria poderão redundar em legislações. Nesses casos, não há parlamentares, há diplomatas que utilizam métodos e procedimentos típicos da dinâmica ou da cultura parlamentar.

No entanto, por causa da pluralidade de participantes, a diplomacia multilateral também tem um lado parlamentar nos métodos de negociação, na medida em que se formam os grupos, as coligações, as alianças, variando de acordo com a organização e áreas em causa, que serão, por vezes, institucionalizadas, de acordo com o ato constitutivo da organização ${ }^{214}$.

Mesmo que a Assembleia Geral das Nações Unidas não tenha sido planejada para ser um órgão legislativo, a prática nos mostra que ela tem assumido o papel principal no processo legislativo internacional. Isso acontece por três motivos: primeiro, ela possui uma legitimidade universal dentre os Estados-membros, por dar uma voz igual a cada Estado; segundo, seu processo deliberativo, de negociação e político possui um padrão estabelecido; terceiro, ela tem competência universal ${ }^{215}$.

Com efeito, a situação mudou e está mais complexa. A Assembleia Geral, ultimamente, tem produzido um grande número de resoluções altamente importantes e declarações, e é inevitável que elas resultem num impacto da produção de legislação internacional. A forma como os Estados votam na Assembleia e as suas justificativas constituem evidências da prática estatal e do entendimento do Estado com o direito internacional. Por exemplo, quando um país vota sistematicamente contra o apartheid, ele não poderia num momento posterior deixar de condenar esse tipo de prática. Há exemplos também de utilização das resoluções como forma de opinio júris $^{216}$.

Quando uma grande maioria de Estados votam consistentemente resoluções e declarações sobre um tópico, isso credencia uma prática estatal e uma regra coercitiva a poder provar na prática que pode ser aprovada. Por exemplo, a Declaração sobre Independência a Países Coloniais e Pessoas, de 1960, que foi adotada sem oposição, com apenas nove abstenções e foi seguida por uma série de resoluções gerais e específicas que atacaram o

In: ORGANIZAÇÃO DAS NAÇÕES UNIDAS. Rules of Procedure. Embodying amendments and additions adopted by the General Assembly up to September 2007. A/520/Rev.17. New York, 2008.

${ }^{214}$ DORMOY, Daniel. Droit des organizations internationales. Paris: Dalloz, 1995. p.73

${ }^{215}$ BOYLE, Alan E. CHINKIN, C. M. The making of international law. Oxford University Press, 2007.P.108-9.

${ }^{216}$ SHAW, Malcolm. International Law. Cambridge: University Press, 2008 
colonialismo, chamando à autodeterminação das colônias restantes. Essas concepções geraram a Declaração de Princípios de Direito Internacional. ${ }^{217}$

As resoluções da Assembleia Geral tornam-se, assim, capazes de acelerar o processo de legalização de determinada prática estatal e, dessa forma, a melhor adaptação do direito internacional à incorporação do nível doméstico ${ }^{218}$. Com isso, suspende-se a clássica posição que descreve a Assembleia como um parlamento meramente consultivo, deixando as decisões coercitivas para serem tomadas pelo Conselho de Segurança ${ }^{219}$. Assim, volta-se para a controvérsia sobre o papel do Conselho de Segurança da ONU e no mundo, em razão da sua composição e métodos de trabalho, sua monopolização das fontes da ONU, desde as reclamações sobre os membros permanentes (e seus vetos) até a sua falta de limite claro de atribuições de cultura legal ${ }^{220}$. De outro modo, a Assembleia Geral, autorizada pelos artigos 10 e 14 da Carta fundamental está apta a tratar de todo e qualquer problema internacional e recomendar medidas para o estabelecimento de paz $^{221}$.

A composição da Assembleia e seus procedimentos refletem uma proposta igualitária para criar um fim global para as atividades da organização, uma conclusão desenhada a partir do insucesso da Liga das Nações. Com maior ou menor efetividade, a diplomacia parlamentar não-eleita nasce na Assembleia Geral das Nações Unidas e, até hoje, desempenha as funções que estão atribuídas nos seus regulamentos.

\subsubsection{Diplomacia Parlamentar Eleita de Função Diplomática}

217 ORGANIZAÇÃO DAS NAÇÕES UNIDAS. Assembleia Geral. XV Sessão. Declaration on the granting of independence to colonial countries and peoples. Resolução 1.514, de 14/12/1960.

${ }^{218}$ SHAW, Malcolm International Law. Cambridge: University Press, 2008 (p.114-119).

${ }^{219}$ SHAW, Malcolm, 2008. Op. Cit.

${ }^{220}$ KOSKENNIEMI, Martti. The Police in the Temple: Order, Justice and the UN: A Dialectical View. European Journal of International Law, 6 (3). 1995. 325-348.

${ }^{221}$ Artigo 10. A Assembléia Geral poderá discutir quaisquer questões ou assuntos que estiverem dentro das finalidades da presente Carta ou que se relacionarem com as atribuições e funções de qualquer dos órgãos nela previstos e, com exceção do estipulado no Artigo 12, poderá fazer recomendações aos Membros das Nações Unidas ou ao Conselho de Segurança ou a este e àqueles, conjuntamente, com referência a qualquer daquelas questões ou assuntos. Artigo 14. A Assembléia Geral, sujeita aos dispositivos do Artigo 12, poderá recomendar medidas para a solução pacífica de qualquer situação, qualquer que seja sua origem, que lhe pareça prejudicial ao bem-estar geral ou às relações amistosas entre as nações, inclusive em situações que resultem da violação dos dispositivos da presente Carta que estabelecem os Propósitos e Princípios das Nações Unidas. ORGANIZAÇÃO DAS NAÇÕES UNIDAS. CARTA DAS NAÇÕES UNIDAS. São Francisco, 26 de junho de 1945. 
De forma distinta da diplomacia parlamentar não-eleita, na diplomacia parlamentar eleita há maior diferenciação das funções dentro das ordens políticas. Assim, mais que aprofundar o conceito, faz-se necessário averiguar quais casos se encaixam nas diferentes funções. As reuniões, grupos de amizade e assembleias possuem identidade e procedimentos próprios que canalizam as discussões para um âmbito de negociação e debate. Mesmo que eles não possuam um poder de legislar stricto sensu, podem deliberar e mostrar interesses comuns na direção de um tema.

$\mathrm{O}$ vínculo que geralmente os mantém ativos são valores democráticos e objetivos comuns, mas também a disposição dos atores de representar seu país em outros locais. "Cabe ao diplomata, na qualidade de negociador, perceber e identificar os interesses comuns que aproximam os governos e, a partir deles, construir o consenso. O diálogo aberto é necessário para afastar ambiguidades e eliminar desconfianças, fatores indispensáveis para a superação de desavenças." 222

Assim, a função diplomática da diplomacia parlamentar assemelha-se à diplomacia pública comum na medida em que inclui a participação em encontros, reuniões, negociações, assembleias e parlamentos nas funções de socialização, aprendizagem, fortalecimento de contatos - a política stricto sensu no sentido luhmanniano. De fato, tal função inclui um fazer diplomático por parlamentares. A diplomacia assim é entendida como o "processo pelo qual as relações diretas com pessoas de um país são exercidas para fazer avançar os interesses e estender os ganhos daqueles que estão sendo representados." 223 A diferença fundamental é que os representantes devem ter sido eleitos diretamente por uma ordem estatal ou supranacional cuja legislatura lhe confira competência e legitimidade.

À atividade da diplomacia parlamentar é atribuído o efeito de socialização que os órgãos parlamentares podem gerar entre seus participantes ${ }^{224}$. O efeito de socialização é um conceito que pressupõe uma capacidade das organizações de gerarem interações sociais, isto é, as condições institucionais e/ou regras informais/formais que afetam práticas de comportamento, normas sobre adequação e preferências sobre resultados, e que são internalizados pelos atores individuais e transmitidos a grupos ou nações ${ }^{225}$.

\footnotetext{
${ }^{222}$ AMARAL JÚNIOR, Alberto do. Curso de Direito Internacional Público. 2a Ed. São Paulo: Editora Atlas, 2011. P. 261.

${ }^{223}$ SHARP, Paul. Revolutionary States, Outlaw Regimes and the Techniques of Public Diplomacy.; MELISSEN, Jan (Org.). The new public diplomacy. Palgrave Macmillan, 2005. P. 107.

${ }^{224}$ STAVRIDIS, Stelios. "Parliamentary Diplomacy": some preliminary findings. Jean Monnet Working Papers in Comparative and International Politics. November 2002 - JMWP n 48.

${ }^{225}$ É um conceito de que teve início na literatura construtivista, de autores integracionistas europeus. In: BEYERS, Jan. International Institutions and Socialization in Europe. International Organization. Vol. 59, No. 4, pp. 899-936. 2005.
} 
A primeira instituição parlamentar de natureza internacional na história da diplomacia parlamentar foi a União Interparlamentar Mundial - IPU ${ }^{226}$, fundada em 1889. No princípio, reunia somente os Parlamentos de poucos países, mas hoje conta com a participação de 152 membros e oito associados, que têm natureza internacional ${ }^{227}$.

A União Interparlamentar Mundial é sem dúvida a mais genuína representação da vontade dos povos para construir um espaço de diálogo e ação que contribua para o desenvolvimento social e a paz mundial. Devemos então consolidar o papel da União Interparlamentar Mundial como mediador de alto nível e considerar os esforços regionais que se levam a cabo no seio do Parlamento Latinoamericano e os Parlamentos regionais Andino, Centroamericano, Amazônico ou Indígena, sem esquecer, é claro, a Confederação Parlamentar das Américas e o Foro Interparlamentar das Américas ${ }^{228}$.

O objetivo de ser mediador reflete uma capacidade e vontade comum entre muitas assembleias e reuniões parlamentares. As próprias delegações nacionais ou supranacionais parlamentares envolvidas em relações multilaterais ou regionais com outros países também desempenham essa função diplomática.

A exemplo do reconhecimento do trabalho do IPU, a Assembleia Geral das Nações Unidas, na $66^{\mathrm{a}}$ Sessão, cumprimentou os esforços feitos pela instituição para estimular uma maior contribuição parlamentar e democrática entre os países. Pela Resolução A/66/L.45, foi proposta uma cooperação mais estreita entre os dois organismos, especialmente para ajudar a fortalecer instituições parlamentares em países de conflito ou passando por uma transição para a democracia $^{229}$.

Através de uma resolução de consenso, a Assembleia das Nações Unidas quer desenvolver uma forma mais estruturada e integrada de trabalho com os parlamentos nacionais. Envolver, entre outros, as consultas sobre as estratégias nacionais de desenvolvimento e sobre a eficácia da ajuda ao desenvolvimento. As Nações Unidas e IPU deverão trabalhá-la intimamente em vários campos, tais como: paz e segurança, desenvolvimento socioeconômico, os direitos humanos e da democracia ${ }^{230}$.

${ }^{226}$ INTERNATIONAL PARLIAMENTARY UNION. Disponível em $<$ http://www.ipu.org $〉>$ Acesso em 12.11.12.

${ }^{227}$ DRI, Clarissa; MALAMUD, Andrés.Spillover Effects and Supranational Parliaments: The Case of Mercosur. Journal of Iberian and Latin American Research V. 19.2. p. 224-238. 2013.

${ }^{228}$ JIMENEZ, Carlos.Diplomacia parlamentar. Diplomacia Parlamentar - Uma Contribuição ao Debate. Instituto Universitas. Brasília-DF: DGrau Multimídia Ltda, 2008.

${ }^{229}$ ORGANIZAÇÃO DAS NAÇÕES UNIDAS. Assembleia Geral. 66a Sessão. 11 ${ }^{\text {a }}$ Reunião. GA/11245. Referências a resoluções A/66/L.45 e A/66/770. 29/5/2012. DepartmentofPublicInformation, New York.

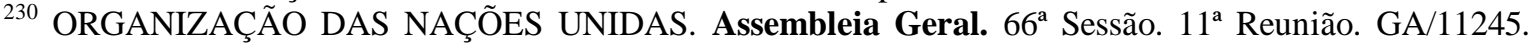

Referências a resoluções A/66/L.45 e A/66/770. 29/5/2012. DepartmentofPublicInformation, New York. 
O fato de essa resolução ser extremamente recente, de 2012, reflete a atualidade do tema, a importância crescente dessas instituições e a necessidade do papel mais ativo de outros atores, nesse caso, da diplomacia parlamentar.

Nesse mesmo sentido, no âmbito regional, destaca-se também a Resolução 1673 de 1999 da Organização dos Estados Americanos. A Resolução reconhece o papel fundamental dos parlamentos nacionais e das redes interparlamentares Latino-Americanas autônomas no desenvolvimento democrático e no papel de fiscalizador.

De fato, no cenário da América Latina, que tem um histórico farto de reuniões e assembleias parlamentárias, destacam-se o Parlamento Latino Americano - Parlatino (1964), a Ação Global de Parlamentares (1978/1979), o Parlamento Centro Americano Parlacen(1991), Conferência Parlamentar das Américas (1997), Fórum Interparlamentar das Américas (2002) e o recente Parlasul (2006).

Dentre esses, vamos detalhar os dois últimos. A Resolução 1673/99 da Assembleia Geral da Organização dos Estados Americanos, além de reconhecer o papel da diplomacia parlamentar, propôs apoiar a formação de uma Rede de Parlamentares das Américas. O objetivo era estabelecer uma rede de parlamentares entre os Estados-membros no âmbito hemisférico para complementar as iniciativas realizadas nos foros parlamentares internacionais, regionais e sub-regionais das América, e acolher os parlamentares nacionais de muitos Estados-membros que tomam medidas para iniciar um diálogo dessa natureza no que se refere à agenda interamericana ${ }^{231}$.

Sob essa prerrogativa, foi formado o Fórum Interparlamentar das Américas (FIPA), em 2001, "reunindo em seu seio os parlamentos nacionais da América em torno do compromisso de contribuir para o processo de integração como um dos instrumentos mais adequados para o desenvolvimento sustentável e harmônico do Continente.”232 O Fórum é composto pelos poderes legislativos dos 26 países membros da OEA, e no seu último encontro, em 2009, teve a participação de 22 delegações, 80 parlamentares e observadores de vários países ${ }^{233}$. Seus objetivos são promover a participação parlamentar interamericana e fomentar o diálogo interparlamentar, aumentar a troca de experiências e cooperação em

231 ORGANIZAÇÃO DOS ESTAdOS AMERICANOS. Assembleia Geral. RESOLUÇÃO 1673/99. Vigésimo Nono Período Ordinário de Sessões Guatemala. De 6 a 8 de junho de 1999. Atas e documentos volume I. Secretaria-Geral. Washington, D.C. 20006. P.256-257.

${ }^{232}$ FORUM INTERPARLAMENTAR DAS AMÉRICAS. Relatorio apresentado pelo Forum das Américas FIPA a V Cúpula de Chefes de Estados e Governos das Américas. Trinidad e Tobago, 2009. Disponível em <www.summit-americas.org/V.../CS/fipa_report_pt.pdf> Acesso em 11/08/13.

${ }^{233}$ FORUM INTERPARLAMENTAR DĀS AMÉRICAS. Relatorio apresentado pelo Forum das Américas FIPA a V Cúpula de Chefes de Estados e Governos das Américas. Trinidad e Tobago, 2009. Disponível em <www.summit-americas.org/V.../CS/fipa_report_pt.pdf> Acesso em 11/08/13. 
questões de interesse comum aos Estados-membros e ajudar a fortalecer o papel dos legislativos na democracia e na promoção e na defesa dos direitos humanos. "O Fórum Interparlamentar das Américas é uma rede independente comprometida em promover a participação parlamentar no sistema interamericano e em contribuir para o diálogo interparlamentar sobre os temas da agenda hemisférica." ${ }^{234}$ Na reunião de trabalho de 2009, o Fórum debateu em sua agenda os temas de: Democracia na América Latina, Cooperação intergovernamental e fortalecimento de políticas de Gênero ${ }^{235}$.

A acumulação de conhecimento é um dos fatores que não pode ser negligenciado nessas atividades parlamentares. O fato é que os parlamentares são capazes de viajar para outros países, participar de atividades interparlamentares e, principalmente, coletar informações de primeira mão que poderão ser utilizadas estrategicamente em seus países. Como eles não são representantes diretos do governo, nem da oposição, eles podem se aventurar em territórios que são frequentemente fora da linha ou prematuros para representantes da diplomacia tradicional ${ }^{236}$.

O Parlamento do MERCOSUL, Parlasul, foi instituído em dezembro de 2005, quando o Conselho do Mercado Comum do MERCOSUL aprovou o Protocolo Constitutivo do Parlamento do MERCOSUL. Essa nova assembleia foi oficialmente instalada em 2006, dando início aos trabalhos em 2007, composta por parlamentares nacionais dos quatro Estados-parte. O Parlasul nasce com poucos poderes em comparação com as funções e competências dos parlamentos nacionais ${ }^{237}$. Por doze anos, o papel de Parlamento foi exercido pela Comissão Parlamentar Conjunta - CPC, integrando os parlamentos nacionais dos Estados-partes com os órgãos institucionais do MERCOSUL, em particular, com o Conselho do Mercado Comum e com o Grupo Mercado Comum ${ }^{238}$. "Na prática, a CPC basicamente buscava acelerar os procedimentos internos de cada Estado Parte para entrada em vigor das normas emanadas do

\footnotetext{
${ }^{234}$ FORUM INTERPARLAMENTAR DAS AMÉRICAS. Relatorio apresentado pelo Forum das Américas FIPA a V Cúpula de Chefes de Estados e Governos das Américas. Trinidad e Tobago, 2009. Disponível em $<$ www.summit-americas.org/V.../CS/fipa_report_pt.pdf> Acesso em 11/08/13.

${ }^{235}$ FORUM INTERPARLAMENTAR DAS AMÉRICAS. Relatorio apresentado pelo Forum das Américas FIPA a V Cúpula de Chefes de Estados e Governos das Américas. Trinidad e Tobago, 2009. Disponível em <www.summit-americas.org/V.../CS/fipa_report_pt.pdf> Acesso em 11/08/13.

${ }^{236}$ STAVRIDIS, Stelios; PACE, Roderick. Regional Parliaments in the Euro-Mediterranean Region: does it amount to Integration? Garnet, Bordeaux, 24 March, 2010. p. 12.

${ }^{237}$ DRI, Clarissa. GARNET Workshop Parliaments in regional integrations (PAREGI), Bordeaux, March 242010.

238 "O Protocolo de Ouro Preto deixou claro que o processo de elaboração de normas constituiria uma forma de função legislativa, ou seja, um processo legislativo que operaria com uma competência normativa a partir de uma sequência de atos, heterogêneos e autônomos, praticados por diversos atores, e dirigidos à produção de normas." No entanto, não outorgou à CPC as competências necessárias à participação neste processo. In: VENTURA, Deisy; PEROTTI, Alejandro D. El Proceso Legislativo der Merscosur. KONRADADENAUER-STIFTUNG E. V.: Montevideo, Uruguay, 2004.
} 
Conselho Mercado Comum (CMC), além de promover uma cultura política integracionista.",239

A ideia do Parlamento regional é que ele funcionasse de forma análoga à União Europeia. "O Mercosul caracteriza-se por uma assimetria interna entre seu propósito constitutivo ambicioso e a fragilidade dos meios colocados a sua disposição pelos Estados Partes." ${ }^{240}$ Assim, mesmo que a ideia fosse semelhante ao projeto Europeu, o MERCOSUL nunca contou com um sistema autônomo de pesos e contrapesos entre as instituições. $\mathrm{O}$ processo legislativo também não tem o poder de propor normas autoaplicáveis. Todas as normas, inclusive os acordos internacionais de cunho comercial com outros países ou blocos, após a conclusão no âmbito do bloco, precisam ser aprovadas pelos parlamentos nacionais.

$\mathrm{O}$ artigo $4^{\circ}$ do Protocolo Constitutivo do Parlasul enumera as competências do Parlamento do MERCOSUL, dentre as quais se destacam:

1. Velar, no âmbito de sua competência, pela observância das normas do MERCOSUL.

2. Velar pela preservação do regime democrático nos Estados Partes, de acordo com as normas do MERCOSUL, e em particular com o Protocolo de Ushuaia sobre Compromisso Democrático no MERCOSUL, na República da Bolívia e República do Chile.

3. Elaborar e publicar anualmente um relatório sobre a situação dos direitos humanos nos Estados Partes, levando em conta os princípios e as normas do MERCOSUL.

4. Efetuar pedidos de informações ou opiniões por escrito aos órgãos decisórios e consultivos do MERCOSUL estabelecidos no Protocolo de Ouro Preto sobre questões vinculadas ao desenvolvimento do processo de integração. Os pedidos de informações deverão ser respondidos no prazo máximo de 180 dias.

5. Convidar, por intermédio da Presidência Pro Tempore do CMC, a representantes dos órgãos do MERCOSUL, para informar e/ou avaliar o desenvolvimento do processo de integração, intercambiar opiniões e tratar aspectos relacionados com as atividade em curso ou assuntos em consideração.

13. Propor projetos de normas do MERCOSUL para consideração pelo Conselho do Mercado Comum, que deverá informar semestralmente sobre seu tratamento.

14. Elaborar estudos e anteprojetos de normas nacionais, orientados à harmonização das legislações nacionais dos Estados Partes, os quais serão comunicados aos Parlamentos nacionais com vistas a sua eventual consideração.

${ }^{239}$ MEDEIROS, Marcelo de Almeida, et al. Legitimidade, representação e tomada de decisão: o Parlamento Europeu e o Parlasul em perspectiva comparada. Revista Brasileira de Política Internacional, 55.1: 154173. 2012. P.162,

${ }^{240}$ VENTURA, D. F. L.. As Assimetrias entre o MERCOSUL e a União Européia - os desafios de uma associação interregional. 1. ed. São Paulo: Manole, 2003. p.3. 
15. Desenvolver ações e trabalhos conjuntos com os Parlamentos nacionais, a fim de assegurar o cumprimento dos objetivos do MERCOSUL, em particular aqueles relacionados com a atividade legislativa. (grifo nosso)

Por meio das competências do Parlasul, é possível visualizar as três funções da diplomacia parlamentar. Os quatro primeiros incisos do art. $4^{\circ}$ destacam o papel de fiscalizador ou de controle do Parlamento. Velar sobre a legalidade do processo regional, a democracia dos Estados-partes, elaboração de relatórios sobre a situação de direitos humanos e, por fim, acompanhar o processo regional por meio de pedidos de informações. O artigo 4.5 pode ser visto como interpretado em consonância com a função diplomática da diplomacia parlamentar, segundo a qual ele pode propor reuniões que levem ao intercâmbio e aprendizagem de informações.

No que se refere à função legislativa, o Parlamento do MERCOSUL possui atribuição compartilhada em matéria de elaboração e recomendação de normas para o MERCOSUL, principalmente a respeito de iniciativa de projetos de normas e harmonização legislativa regional. Não obstante, trata-se de um órgão autônomo, diferentemente de outras assembleias parlamentares anteriormente referidas, pois não está vinculado a nenhum governo ou órgão executivo nacional. "Apesar de o Parlamento trabalhar com questões legislativas, ele não produz normas imperativas: sua inteira produção - pareceres, projetos de normas, declarações, recomendações, relatórios e disposições - deve ser apreciada pelo CMC antes de ser aplicada pelos quatro Estados Partes."241

Assim, a diplomacia parlamentar eleita do MERCOSUL já conta com um atenuado e tímido entrelaçamento, uma vez que o Parlasul não conta com uma iniciativa legislativa autônoma (artigo 4.13 do Protocolo Constitutivo), mas tem a capacidade de enviar suas propostas legislativas para o Conselho do Mercado Comum.

A diplomacia parlamentar é caracterizada com função diplomática, fiscalizadora e legislativa baixa. Há uma centralização nos seus órgãos principais pelos governos executivos nacionais, uma vez que o Ministério das Relações Exteriores de cada país detém o poder de negociação e decisão em todas as instâncias, com exceção do Parlamento, sem poderes. As decisões são tomadas por consenso e, assim, as instituições regionais não contam com qualquer autonomia.

Isso se deve à falta de estrutura, consistência e desorientação de integração:

\footnotetext{
${ }^{241}$ MEDEIROS, Marcelo de Almeida, et al. Legitimidade, representação e tomada de decisão: o Parlamento Europeu e o Parlasul em perspectiva comparada. Revista Brasileira de Política Internacional. 55.1: 154173. 2012. P.164.
} 
As grandes linhas do direito comunitário não encontram nenhum eco nos contornos jurídicos do Mercosul. Em primeiro lugar, o Mercosul adota uma estrutura institucionalmente minimalista. Em segundo lugar, o bloco não é dotado de uma ordem jurídica autônoma, e constitui, assim, um fenômeno de direito internacional clássico, o que revela uma profunda assimetria entre os dois modelos de integração ${ }^{242}$.

Enquanto na União Europeia, ao menos no plano dos Estados-membros, estão presentes os pressupostos para a formação de uma organização fundada no constitucionalismo transversal, no que diz respeito tanto à democracia quanto ao Estado de Direito, o MERCOSUL ainda não preenche tais condições mínimas, com duplo déficit democrático, presente tanto nos Estados quanto na organização regional de integração, e o duplo déficit de Estado de Direito ${ }^{243}$.

A União Europeia, assim como a Europa, é um exemplo tradicional que mantém inúmeras delegações em outros países com acordos formais, no caso, Assembleias parlamentares regionais como Assembleia Parlamentar Mista África-Caribe-Pacífico e União Europeia (ACP-EU Joint Parlimentary Assembly), e talvez o mais tradicional encontro de parlamentares, o Diálogo Transatlântico de Legisladores, que reúne o Parlamento Europeu e o Congresso Americano, antes chamado de EP-US Congress.

Em especial, para a presente tese, importa a Assembleia Parlamentar Euro-LatinoAmericana (EUROLAT), que reúne União Europeia, Caribe e América Latina. A EUROLAT foi criada em 2006 e, de 1974 até a sua criação, havia dezessete conferências interparlamentares bianuais entre o Parlamento Europeu (PE) e diferentes representações parlamentares do continente Latino-Americano, como o Parlatino (Parlamento Latinoamericano), Parlandino (Parlamento Andino), Parlacen (Parlamento Centro-Americano) e, em seguida, com o Parlasul (Mercosul) ou com sua Comissão Parlamentar Conjunta. Dentro desse contexto, a criação da EUROLAT pode ser vista como o cumprimento dos desejos de ambos, o PE e as várias assembleias regionais Latino-americanas, e como um passo a frente no desenvolvimento das relações entre as duas regiões (UE-América Latina). ${ }^{244}$

Desde 2006, a EUROLAT conta reuniões ordinárias anuais, produzindo resoluções e documentos sobre todos os temas que envolvam as duas regiões, como, por exemplo, a Resolução sobre a Luta contra o Narcotráfico e a Delinquência Organizada, de 2013,

\footnotetext{
${ }^{242}$ VENTURA, D. F. L.. As Assimetrias entre o MERCOSUL e a União Européia - os desafios de uma associação interregional. 1. ed. São Paulo: Manole, 2003. p.2.

${ }^{243}$ NEVES. M. Op. cit. 2009. p.91.

${ }^{244}$ STAVRIDIS, Stelios; AJENJO, Natalia. EU-Latin American Parliamentary relations: some preliminary comments on the EUROLAT. Jean Monnet/Robert Schuman Paper Series Vol. 10, No. 3, April 2010.
} 
Resolução sobre Políticas Energéticas de 2008, ou ainda Projetos, como o Projeto de Educação formal, informal e educação contínua, que está em vigor ${ }^{245}$.

O Regulamento Interno define as diretrizes de composição e competência. De acordo com art. $2^{\circ}$, a EUROLAT é composta por 150 parlamentares, sendo 75 do Parlamento Europeu e 75 membros do continente Latino-americano. De acordo com art. $3^{\circ}$, é competente como fórum de discussão, consulta, controle e monitoramento de todas as questões relativas à parceria estratégica Birregional. Para este fim, a Assembleia tem o poder de adotar resoluções e recomendações que serão encaminhadas para os órgãos governamentais competentes ${ }^{246}$.

O seu Ato Constitutivo destaca, dentre seus objetivos, a promoção e aprofundamento de vários aspectos práticos da Associação Estratégica Birregional em três frentes: nível político (incluindo a promoção da democracia, a integração, a paz, a governabilidade/ governança e Direitos Humanos); econômica (incluindo as relações comerciais e financeiras); e social (incluindo o ambiente, a educação e as questões de migração) ${ }^{247}$.

Continua a ser um paradoxo para EUROLAT como a União Europeia, na qual quase todos os seus Estados-Membros têm democracias parlamentares, desenvolverá as suas relações com a América Latina, que tem democracias dominadas pelo Poder Executivo, deixando um papel muito limitado de tomada de decisão para a sua dimensão parlamentar. E o contrário: os regimes presidenciais na América Latina tiveram uma influência parlamentar nos seus respectivos esforços de integração sub regionais ${ }^{248}$.

Outros parlamentos regionais que não possuem poder de decisão, mas se reúnem como órgãos parlamentares subnacionais, são o Parlamento catalão, o Parlamento escocês, ou o Parlamento de Quebec, que também possuem um papel internacional. ${ }^{249}$

Além desses, há casos no mediterrâneo, como a Assembleia Parlamentar EuroMediterrânea - EMPA (Euro-MediterraneanParliamentary Assembly) e a Assembleia Mediterrânea Parlamentar - PAM (Parliamentary Assembly oftheMediterranean), que não têm poderes legislativos e podem apenas aprovar resoluções não obrigatórias e fazer

${ }^{245}$ EUROLAT. Documentos e Eventos. Disponível em <http://www.europarl.europa.eu/> Acesso em $01 / 07 / 13$.

${ }^{246}$ EUROLAT. ASSEMBLEIA PARLAMENTAR EURO-LATINO-AMERICANA. REGLAMENTO. 25/01/13. Disponível em 〈http://www.europarl.europa.eu/intcoop/eurolat/key_documents/rules_of_procedure 2013/926146es.pdf> Acesso em 01/07/13.

247 EUROLAT. ASSEMBLEIA PARLAMENTAR EURO-LATINO-AMERICANA. ACTA CONSTITUTIVA DE LA ASAMBLEA PARLAMENTARIA EURO-LATINOAMERICANA. 2006. Disponível em <http://www.europarl.europa.eu/intcoop/eurolat/key_documents/acta_constitutiva_es.pdf>

${ }^{248}$ STAVRIDIS, Stelios; AJENJO, Natalia. EU-Latin American Parliamentary relations: some preliminary comments on the EUROLAT. Jean Monnet/Robert Schuman Paper Series Vol. 10, No. 3, April 2010.

${ }^{249}$ STAVRIDIS, Stelios 2002. Op. Cit. 
recomendações para os governos e outras organizações, como a UE. ${ }^{250}$ Contudo, ambas as assembleias - PAM e EMPA - podem exercer, por meio de seu papel consultivo, influências importantes em determinados setores, por exemplo:

As assembleias podem exercer uma contribuição válida e com tempo, por meio de uma gradual aquisição de poder e prestígio, tornar-se plenamente formada por mecanismos de integração com seu próprio direito. Eles também podem ser influências positivas no processo de cooperação e integração, facilitando a resolução de conflito e problemas, gerando metas e ideais para os próximos passos e ações como catalisadoras da construção de consenso $^{251}$.

A noção de uma diplomacia parlamentar diplomática responde ao problema do déficit democrático no momento em que inclui novos atores. A inclusão de atores legítimos a entrar em contato com outros parlamentares igualmente legítimos faz com que o alter, esquecido das relações internacionais, tenha um lugar ao sol. A inclusão do alter no debate internacional é a materialização de um potencial do método transconstitucional, na medida em que proporciona uma forma de inclusão de outro ponto de vista, não apenas de atores unitários. Nessa medida, contribui também para o entrelaçamento de ordens legislativas.

Contudo, sua maior contribuição está no potencial democrático agregador respondendo à tese da fragmentação do direito e da descontinuidade das normas. O direito internacional é império e hegemônico na medida em que limita a participação de novos atores legítimos. O direito internacional pode contar com uma crescente contribuição sempre que houver espaços a serem tomados por atores com a característica multidimensional da democracia.

\subsubsection{Diplomacia Parlamentar eleita de Função de Fiscalização}

Os parlamentos ocupam crescentemente um papel fiscalizante, consultivo, até mesmo de opinião pública. A segunda função que mais se destaca na diplomacia parlamentar está ligada a um poder tradicional dentro das funções parlamentares: a fiscalização ou controle.

\footnotetext{
${ }^{250}$ STAVRIDIS, Stelios; PACE, Roderick. Regional Parliaments in the Euro-Mediterranean. Region: does it amount to Integration? Garnet, Bordeaux, 24 March, 2010. p. 9.

251 STAVRIDIS, Stelios; PACE, Roderick. Regional Parliaments in the Euro-Mediterranean. Region: does it amount to Integration? Garnet, Bordeaux, 24 March, 2010. p. 21.
} 
"O Poder Legislativo é uma instituição fundamental da democracia representativa, porque se compõe de representantes do povo, para o exercício de duas funções básicas: a legislativa e a de controle sobre o governo." 252

A diplomacia parlamentar tem participado em diversas ordens políticas com a função de observar ou avaliar como certas legislações extranacionais ou estatais são implementadas. A função da fiscalização não exclui a diplomática, isto é, são funções complementares que podem ser atribuídas simultaneamente, inclusive pelas mesmas instituições já citadas na categoria anterior. A função fiscalizadora inclui processos consultivos e de investigação.

No que se refere aos exemplos estatais, há uma comprovada participação dos parlamentares em questões ligadas aos direitos humanos, tanto individualmente como, em alguns casos, por meio da Comissão de Direitos Humanos da Câmara Federal ou de Comissões Estaduais de Direitos Humanos. Casos paradigmáticos envolvem Damião Ximenes Lopes e a Fábrica de Fogos de Santo Antônio de Jesus, nos quais o empenho de parlamentares estaduais e federais foi determinante para a denúncia de corrupção ou injustiça de outras ordens políticas e jurídicas na proteção internacional dos direitos humanos ${ }^{253}$.

O caso Damião Ximenes Lopes é particularmente paradigmático, por ter se tornado a primeira condenação do Brasil pela Corte Interamericana de Direitos Humanos, da Organização dos Estados Americanos (OEA). O Brasil foi condenado com base nos artigos $4^{\circ}$ e $5^{\circ}$ da Convenção, reconhecidas pelo próprio Estado, e também dos artigos 8(1) e 25 da Convenção, relacionados com o fato de Damião ter um transtorno mental e a demora da Justiça brasileira nos processos criminal e cível ajuizados pela família ${ }^{254}$.

\footnotetext{
${ }^{252}$ SILVA, José Afonso da. Processo Constitucional de Formação das Leis. $2^{\mathrm{a}}$ ed. São Paulo: Malheiros, 2006. P. 60.

${ }^{253}$ A explosão da fábrica de fogos de artifícios em Santo Antônio de Jesus, Bahia, no dia 11 de dezembro de 1998, matou 64 pessoas, de 42 famílias, na sua maioria entre 12 e 22 anos. A ação penal e civil apontou como responsáveis, todos integrantes da mesma empresa ilegal de fabricação de fogos, somente após a atuação da Comissão de Direitos Humanos da Assembleia Legislativa da Bahia, em especial, o parlamentar Yulo Oiticica, articulador de uma série de ações de mobilização junto ao Movimento 11 de dezembro. Contudo, ainda após 15 anos, ainda não houve sentença. O caso foi denunciado na Comissão Interamericana de Direitos Humanos e também pelo Alto Comissariado de Defesa dos Direitos Humanos da Organização das Nações Unidas (ONU). In: SANTOS, Lindinalva dos, VELLOSO, Tatiana Ribeiro Velloso. Aprendizados no Processo de Construção de Alternativas de Inclusão Social do Grupo do Movimento 11 de Dezembro no Município de Santo Antonio de Jesus-BA. NAU Social 3.5 63-68, 2012.; JUSTIÇA GLOBAL. Santo Antônio de Jesus, 15 anos de impunidade. Tragédia dos fogos de artifícios. 6 DE SETEMBRO DE 2013. Disponível em <http://global.org.br/programas/santo-antonio-de-jesus-15-anos-de-impunidade-tragedia-dosfogos-de-artificios/>Acesso em 7/10/13.

${ }^{254}$ A vítima faleceu em quatro de outubro de 1999 na Casa de Repouso Guararapes, no Estado do Ceará, após ser internada para tratamento psiquiátrico, centro de atendimento psiquiátrico privado, que operava no âmbito do sistema público de saúde do Brasil, chamado Sistema Único de Saúde. A sentença da Corte determinou que o Brasil deveria reparar moralmente e materialmente a família Ximenes, através do pagamento de uma indenização e outras medidas não pecuniárias. Dentre elas, o Brasil foi instado a investigar e identificar os culpados da morte de Damião em tempo razoável e também promover programas de formação e capacitação
} 
Além do entendimento de que a demora nos processos favorece a impunidade e proporciona a violação do direito de acesso à justiça, a leitura dos fatos indica uma blindagem política ao devido processo legal e investigação dos fatos. Os responsáveis pelo falecimento de Damião Ximenes Lopes foram condenados, primeiro, porque sua irmã e sua mãe não se conformaram com a falta de investigação das autoridades competentes, mas, ao contrário, reivindicaram justiça perante diversos organismos públicos. "A senhora Albertina Viana Lopes, mãe da suposta vítima, recorreu à Coordenação Municipal de Controle e Avaliação da Secretaria de Saúde e Assistência Social, e a senhora Irene Ximenes Lopes Miranda, irmã da suposta vítima, recorreu à Comissão de Cidadania e Direitos Humanos da Assembleia Legislativa do Estado do Ceará.”255

Assim, João Alfredo Teles Melo, que na época dos fatos era deputado da Assembleia Legislativa do estado do Ceará, em que presidia a Comissão de Direitos Humanos e Cidadania, torna-se um dos principais atores e testemunhas do litígio.

A Comissão de Direitos Humanos e Cidadania funciona como um balcão onde a população pode apresentar demandas, queixas e reclamações e, em seguida, a Comissão faz o encaminhamento das mesmas aos órgãos responsáveis. Ela tem a função de acompanhar o seguimento das queixas, seja cobrando providências ou realizando audiências públicas em matéria de direitos humanos. No caso do senhor Damião Ximenes Lopes, convidou-se a sua irmã e sua mãe e outros pacientes que estiveram na Casa de Repouso Guararapes para prestarem depoimento, foram dirigidos ofícios e aprovadas moções que foram dirigidas a distintas autoridades solicitando a adoção de medidas, tanto no âmbito administrativo e disciplinar -para o Conselho de Medicina, para a Prefeitura de Sobral, através da Secretaria de Saúde, para a Secretaria de Saúde do Estado-, como também para autoridades policiais e judiciais ${ }^{256}$.

Por isso, tantas vezes, à diplomacia parlamentar será atribuído o papel de denúncia, de controle e fiscalização.“O instrumento parlamentar de controle mais comum está no poder de

para profissionais de saúde, especialmente médicos/as psiquiatras, psicólogos/as, enfermeiros/as e auxiliares de enfermagem, bem como para todas as pessoas vinculadas ao campo da saúde mental. In: ORGANIZAÇÃO DOS ESTADOS AMERICANOS. Corte Interamericana De Direitos Humanos. Caso Ximenes Lopes versus Brasil. Sentença de 4 de julho de 2006. Mérito, Reparações e Custas. (Caso 12.237) San José, Costa Rica.

255 Em 12 de dezembro de 2000, a senhora Irene Ximenes Lopes Miranda solicitou ao Presidente da Comissão de Cidadania e Direitos Humanos da Assembleia Legislativa do Estado do Ceará que requeresse ao Juiz da Terceira Vara de Sobral o aditamento da denúncia contra as pessoas mencionadas no ofício dos promotores do Centro de Apoio Operacional dos Grupos Socialmente Discriminados da Procuradoria-Geral de Justiça. In: ORGANIZAÇÃO DOS ESTADOS AMERICANOS. Corte Interamericana De Direitos Humanos. Caso Ximenes Lopes versus Brasil. Sentença de 4 de julho de 2006. Mérito, Reparações e Custas. (Caso 12.237) San José, Costa Rica.

${ }^{256}$ ORGANIZAÇÃO DOS ESTADOS AMERICANOS. Corte Interamericana De Direitos Humanos. Caso Ximenes Lopes versus Brasil. Sentença de 4 de julho de 2006. Mérito, Reparações e Custas. (Caso 12.237) San José, Costa Rica. P.5. 
tornar notória e apontar à opinião pública, por meio de solicitação de explicações, interpelações e inquéritos, a atuação do Executivo". ${ }^{257}$ Assim, observa-se uma faceta importante do trabalho parlamentar dedicado às relações internacionais.

O papel de tribunal moral é geralmente vinculado a função dos parlamentos. Isso quer dizer que a realpolitik pode existir e existe na política externa, mas há outros elementos mais idealistas, pluralistas, que geralmente são expressos nos corpos parlamentares, consideradas como casas de debate. Isso pode ser facilmente observado a partir do desenvolvimento da Liga das Nações, das Nações Unidas, dos processos regionais e dos Estados nacionais ${ }^{258}$.

Paralelamente, nota-se, na Europa, um aumento no número de pedidos de desculpas públicas para os erros do passado, provocados pelos Parlamentos. O Estado arrepende-se da colonização, da escravidão e dos genocídios. Na América Latina, pede-se perdão pelos crimes cometidos durante as ditaduras militares. Há participação mais ativa em inquéritos parlamentares sobre questões complexas, como a limpeza étnica ou outras atrocidades do passado. Como exemplo, tanto os parlamentos franceses como os holandeses elaboraram relatórios sobre as ações de seus soldados nos massacres de Srebrenica em Julho de $1995^{259}$.

Outro mecanismo no qual se observa participação de parlamentares dos três níveis de governo são alguns procedimentos especiais da $\mathrm{ONU}$, em especial durante suas visitas ao Brasil.

Nesses momentos, em praticamente todas estas visitas, os relatores
dialogaram com vereadores, deputados estaduais e federais. Audiências
públicas foram realizadas em câmaras municipais (como, por exemplo, em
Guarulhos, durante a visita da relatora especial sobre Execuções Sumárias
em 2003) ou assembleias legislativas estaduais. A participação de
parlamentares comprometidos com a proteção dos direitos humanos se
reflete também na maior participação de organizações locais que trabalham
com os temas objeto das visitas. O papel catalisador dos parlamentares é
muito importante e certamente poderia ser fortalecido ${ }^{260}$.

Contudo, sabe-se que essa conduta não é a regra. Ao contrário, o comportamento padrão é um distanciamento de assuntos externos, uma vez que eles não contam com um retorno eleitoral do povo constitucional que reelegerá os deputados. A accountabiliy, no

\footnotetext{
${ }^{257}$ BOBBIO, Norberto. Dicionário de política.10. ed. Sérgio Bath. Brasília: UnB, 1997.

${ }^{258}$ STAVRIDIS, Stelios. "Parliamentary Diplomacy": some preliminary findings. Jean Monnet Working Papers in Comparative and International Politics. November 2002 - JMWP n 48.

${ }^{259}$ STAVRIDIS, Stelios. "Parliamentary Diplomacy": some preliminary findings. Jean Monnet Working Papers in Comparative and International Politics. November 2002 - JMWP n ${ }^{\circ} 48$.

${ }^{260}$ ASANO, AMPARO, 2008. Op. Cit.
} 
sentido de responsabilização e fiscalização parlamentar em assuntos externos, é ainda fraca, independentemente do tipo de sistema político que existe em qualquer democracia liberal.

Um caso de destaque nesse âmbito foi o debate da ALCA no Congresso Nacional brasileiro, com a criação da Frente Parlamentar de Acompanhamento das Negociações da Alca em Defesa da Soberania e com o Projeto de Emenda à Constituição 52/2001 ${ }^{261}$.

No dia 22 de outubro de 2003, a referida Frente, na figura da Deputada Clair Martins (PT-PR), publicou um manifesto que reivindicava a ampliação do debate democrático da negociação da ALCA e, para isso, a ampliação da participação dos parlamentares nesse debate: "Nós, parlamentares do Brasil, lutamos por acordos internacionais que respeitem a Soberania Nacional, entendendo serem importantes para o combate à pobreza, para a promoção dos valores democráticos e para impulsionar o desenvolvimento comum dos povos das Américas."262

Contudo, o efeito mais significativo da Frente Parlamentar nas negociações da ALCA foi a própria reflexão do Senado brasileiro sobre seu escasso poder formal nos debates de formação de política externa. A análise do debate e atuação do Congresso tornou evidente o expressivo nível de preocupação dos parlamentares com relação à ALCA e outras questões comerciais, "sendo possível afirmar que a integração do continente motivou, direta ou indiretamente, o interesse dos senadores, em especial, em ampliar de modo significativo as atribuições do Congresso Nacional em matéria de política de comércio exterior.”"263

Com efeito, a Proposta de Emenda à Constituição 52/2001 é um exemplo de uma tentativa de inclusão do Congresso Nacional no debate da política externa, ao menos em matéria de comércio internacional. A justificativa do projeto de lei é uma crítica forte e lúcida ao atual sistema de incorporação legislativa brasileiro: "a agenda do comércio mundial para os próximos quatro anos não poderá transformar o Congresso Nacional num mero fantoche, homologador de acordos comerciais decididos na esfera do Executivo (...). ${ }^{264}$ O projeto

\footnotetext{
${ }^{261}$ Entre os deputados que integraram a Frente estão seu coordenador, deputado Luiz Eduardo Greenhalgh (PT-SP), Chico Alencar [PT-RJ], Ivan Valente [PT-SP], Luiza Erundina [PSB-SP], Jamil Murad [PCdoBSP], Ari Vanazzi [PT-RS] e Adão Pretto [PT-RS]. In: CAMARA DOS DEPUTADOS. Agência de Notícias da Câmara. Disponível em <http://agencia-camara.justica.inf.br/noticia/2003/8/frente-da-alca-reune-se-daquia-pouco> Acesso em 10/10/13.

${ }^{262}$ BRASIL. CONGRESSO. CÂMARA DOS DEPUTADOS DO BRASIL. Discurso de Plenária. Deputada Clair Martins (PT-PR). 22/12/2003. Disponível em <www.camara.gov.br/sileg/integras/178226.doc> Acesso em 10/10/2013.

263 OLIVEIRA, Rodrigo Regazonni. O Congresso Nacional e a Política Externa Brasileira. Posicionamento dos senadores frente às negociações para a formação da ALCA (1994-2005). 2011. 138f. Dissertação Programa de Pós-Graduação em História, UNB. Brasília, 2011. p. 116.

264 BRASIL. SENADO FEDERAL. DIÁRIO DO SENADO FEDERAL. Proposta de emenda à
}

Constituição No 52, 2001. Sexta-feira, 30 de Novembro de 2001. p. 29892. 
trouxe como proposta o acréscimo de inciso e parágrafo único ao art. 49 e outro inciso ao art. 84 da Constituição Federal:

“Art. 49: é da competência exclusiva do Congresso Nacional:

XVIII: acompanhar as negociações realizadas pelo Poder Executivo dos atos, acordos, convênios e tratados que versem sobre matéria de comércio internacional, desde o seu início até o momento de sua conclusão, para assinatura entre o Brasil e os países signatários.

Parágrafo único. O Congresso Nacional terá um prazo de até 30 dias para emissão de relatório autorizativo para assinatura dos atos, acordos, convênios e tratados referidos no inciso XVIII."

“Art. 84. Compete privativamente ao Presidente da República:

XXVIII: - submeter ao Congresso Nacional, para o acompanhamento de seu processo de elaboração até a fase de sua conclusão, para assinatura entre o Brasil e seus países signatários, os atos, acordos, convênios e tratados que versem sobre matéria de comércio internacional, desde o início de suas negociações." 265

O projeto, de autoria principal do Senador Roberto Requião (PMDB-PR), foi adiado pelo Senador Aloizio Mercadante (PT-SP), sendo arquivado em 22 de janeiro de 2007, pelo fim da Legislatura ${ }^{266}$. Ironicamente, a justificativa do adiamento e nova diligência à Comissão de Constituição Justiça e Cidadania, que levou ao arquivamento à revelia, foi fundamentado por não avançar o suficiente no que toca aos poderes do parlamento: "a redação dada à Proposta não alcança o objetivo (inserção do Parlamento no processo de formulação, negociação e implantação da política exterior), pois na proposta o parlamento se limitaria a acompanhar as negociações, não participando da formação ou negociação comercial."267 Contudo, na avaliação anterior da Comissão de Constituição, Justiça e Soberania, em 19 de junho de 2002, o projeto teve parecer favorável e foi aprovado, sendo relator o Senador José Fogaça, que destaca no voto:

265 BRASIL. SENADO FEDERAL. DIÁRIO DO SENADO FEDERAL. Proposta de emenda à Constituição No 52, 2001. Sexta-feira, 30 de Novembro de 2001. p. 29890.

266، Art. 332. Ao final da legislatura serão arquivadas todas as proposições em tramitação no Senado, exceto: I - as originárias da Câmara ou por ela revisadas; II - as de autoria de Senadores que permaneçam no exercício de mandato ou que tenham sido reeleitos; III - as apresentadas por Senadores no último ano de mandato; IV - as com parecer favorável das comissões; V - as que tratem de matéria de competência exclusiva do Congresso Nacional (Const., art. 49); VI - as que tratem de matéria de competência privativa do Senado Federal (Const., art. 52); VII - pedido de sustação de processo contra Senador em andamento no Supremo Tribunal Federal (Const., art. 53, §§ 3o e 4o, EC no 35/2001)." In: BRASIL. CONGRESSO. SENADO FEDERAL. Regimento Interno: Resolução $n^{\circ}$ 93, de 1970. Brasília: Senado Federal. ; BRASIL. SENADO FEDERAL. SSCLSF - SUBSEC. COORDENAÇ̃̃O LEGISLATIVA DO SENADO PEC - PROPOSTA DE EMENDA À CONSTITUIÇÃO, $\mathbf{N}^{\mathbf{0}} 52$ de 2001. Situação: ARQUIVADA AO FINAL DA LEGISLATURA. Matéria arquivada ao final da $52^{\mathrm{a}}$ Legislatura, nos termos do art. 332 do Regimento Interno e do Ato $\mathrm{n}^{\circ}$ 97, de 2002, do Presidente do Senado Federal. Disponível em: <http://www.senado.gov.br/ atividade/materia/detalhes.asp?p_cod_mate=49034> Acesso em 10/10/2013.

${ }^{267}$ In: BRASIL. SENADO FEDERAL. DIÁRIO DO SENADO FEDERAL. Requerimento No 825/2003. Senador Aloizio Mercadante. Quinta-feira, 18 de Setembro de 2003. p. 27437. 
De imediato, o Parlamento brasileiro terá pela frente o desafio da montagem, em um curto espaço de tempo, de uma estrutura leve, porém ágil, no cenário do Congresso Nacional, capaz de providências o estudo e a análise de propostas de negociação para o ingresso do Brasil no bloco econômico da União Europeia e uma possível Área de Livre Comércio das Américas, a ALCA, além de buscar acelerar as negociações comerciais destinadas a fortalecer, ampliar e consolidar o Mercosul (.... $)^{268}$.

O fato de o voto do Relator incluir as negociações da ALCA e as questões regionais do MERCOSUL e União Europeia demonstra preocupação e interesse do Congresso nos temas estratégicos da época ao Brasil. Essa atenção incorpora uma visão democrática e constitucional que vai além da Constituição brasileira positivada, isto é, da Constituição posta: "No Brasil de hoje prevalece a visão ultrapassada, mesmo na Constituição Federal de 1988, de que as questões de política exterior são de exclusiva competência do Executivo, cabendo ao Legislativo apenas a função homologatória dos seus atos internacionais." 269

Assim, podemos entender que uma visão transconstitucional da diplomacia parlamentar brasileira necessariamente precisa ir além da constituição vigente. "Maior ingerência do Poder Legislativo nos temas concernentes à política externa é, indubitavelmente, uma das mais importantes tendências da relação entre Poderes nas democracias modernas., 270

A noção de Constituição é mais do que uma ideia positivada. Um dos seus objetivos é conter o poder, distribuí-lo, fazer com o que poder político seja controlado. A Constituição surge como uma resposta complexa aos problemas que ensejaram o surgimento do Estado moderno: controle de poder e afirmação dos direitos humanos. ${ }^{271}$

Pode-se afirmar, portanto, que a constituição brasileira atual é menos constitucional quando limita a atuação do Poder Legislativo e concentra no Poder Executivo à função de Política Externa.

O próprio Ministério de Relações Exteriores (MRE) tem modificado sua estrutura nos últimos anos para melhor responder às demandas oriundas dos Parlamentos federal e estaduais. Recentemente, o MRE criou a Assessoria Especial para Assuntos Federativos $e$ Parlamentares. Suas atribuições incluem assistência direta ao ministro, a articulação entre o

\footnotetext{
${ }^{268}$ BRASIL. SENADO FEDERAL. DIÁRIO DO SENADO FEDERAL. Parecer No 861/2002, da Comissão de Constituição Justiça e Cidadania. Quinta-feira, 8 de Agosto de 2002. p. 15544.

${ }^{269}$ BRASIL. SENADO FEDERAL. DIÁRIO DO SENADO FEDERAL. Parecer No 861/2002, da Comissão de Constituição Justiça e Cidadania. Quinta-feira, 8 de Agosto de 2002. p. 15544.

270 BRASIL. SENADO FEDERAL. DIÁRIO DO SENADO FEDERAL. Parecer № 861/2002, da Comissão de Constituição Justiça e Cidadania. Quinta-feira, 8 de Agosto de 2002. p. 15544.

${ }^{271}$ NEVES, Marcelo. Op. Cit. 2009. P. 91.
} 
MRE e o Poder Legislativo e o atendimento às consultas e aos requerimentos formulados pelos parlamentares. ${ }^{272}$

A função fiscalizadora é uma das mais recorrentes e democratizantes de uma gradual politização do processo político global, principalmente porque ela responde a duas das críticas mais contundentes do neoinstitucionalismo - o déficit democrático e accountability - com uma resposta que já existe: diplomacia parlamentar. Ou seja, sem necessidade de criar ou inventar novas instituições, com custo elevado ou novas desconfianças. Essa função privilegia o código governo/oposição na medida em que proporciona que a oposição também seja representada no nível extranacional.

A diplomacia parlamentar eleita função legislativa é propriamente o objeto dos entrelaçamentos de ordens legislativas, e, por isso, emerge nos casos que serão analisados nos próximos dois capítulos.

${ }^{272}$ ASANO, AMPARO, 2008. Op. Cit. 


\section{OS ENTRELAÇAMENTOS DE ORDENS LEGISLATIVAS SUPRANACIONAL/NACIONAL: UNIÃO EUROPEIA/ESTADOS-MEMBROS}

A diplomacia parlamentar que mais interessa a este estudo é a diplomacia parlamentar eleita com função legislativa. Ela compreende os parlamentares nacionais e supranacionais que são eleitos e nos seus próprios parlamentos exercem funções de debate, negociação e aprovação de tratados ou normas de organizações internacionais, trazendo para o âmbito interno algo que é externo. Trata-se de um processo formal, vinculado aos atos legislativos previstos nas suas constituições.

No plano supranacional, o único bloco regional que alcançou o nível de supranacionalidade é a União Europeia. Sua estrutura institucional proporciona a produção de normas autoaplicáveis e tem no Parlamento Europeu, com eleições diretas desde 1979, um ator central no círculo freios e contrapesos multidimensional formado pelo Conselho, Conselho Europeu, Comissão, Tribunal e Parlamento.

Sob a perspectiva do multilateralismo e de maior abertura democrática, as instituições regionais que contam com parlamentos incluem um papel diferenciado: a representação dos cidadãos - não apenas dos Estados nacionais. Essa representação se dá por meio da diplomacia parlamentar, descentralizando a política externa do uso exclusivo do Executivo. Esses parlamentares regionais, portanto, fazem parte da diplomacia parlamentar eleita, assim como parlamentares nacionais no debate e na aprovação de normas internacionais, quando elas figuram na agenda de parlamentos nacionais.

A estrutura institucional e a composição jurídica da União Europeia entrelaçam as ordens legislativas pelo equivalente funcional de normas autoaplicáveis. O fundamento do entrelaçamento da ordem supranacional (europeia) com a ordem nacional (dos Estados- 
membros) jaz nessa capacidade de produção legislativa. Portanto, a ponte de transição entre uma ordem e outra se dá pela imposição de legislação comunitária sem a aprovação posterior dos parlamentos nacionais, quando algumas matérias se tornam de exclusividade comunitária, deixam de ter atribuição parlamentar nacional.

Nesse caso, a ponte de transição, o acoplamento estrutural, que entrelaça a União Europeia com seus Estados-membros é a força normativa do resultado de seu processo legislativo. "O que distingue a união europeia de qualquer outra organização internacional, no entanto, é a combinação de aplicabilidade imediata e primazia do direito comunitário."273

Contudo, as normas autoaplicáveis foram antecipadas a uma estrutura democrática equivalente. Essa estrutura foi inicialmente criticada pelo seu déficit democrático. $\mathrm{Na}$ verdade, o que faltava era um adicional equivalente funcional, nesse caso, um equivalente funcional aos parlamentos nacionais, dentro da estrutura da UE. ${ }^{274}$ Para ter um equivalente funcional que garantisse legitimidade para às decisões do bloco seria necessário criar um Parlamento Europeu nos moldes de um parlamento nacional, em poder e representação.

Essa transformação acontece a partir dos anos 70 , quando se entende que parte do déficit seria absorvido se o Parlamento fosse eleito através do voto direito e se lhe fossem atribuídos os poderes de controle, legislativo e financeiro, equivalentes aos parlamentos nacionais ${ }^{275}$. Assim, seus poderes têm sido progressivamente conquistados àqueles de que dispõem os parlamentos das democracias modernas, ainda que a comparação seja difícil diante das diferenças que cada sistema político nacional guarda em relação ao Parlamento ${ }^{276}$.

Contudo, os poderes do Parlamento Europeu como um órgão de controle democrático permaneceram insuficientes até o Tratado de Lisboa (2009) ${ }^{277}$, quando torna-se um ator forte, sobretudo quanto ao domínio da iniciativa das leis, da política de despesas e da nomeação da Comissão Europeia $^{278}$.

\footnotetext{
${ }^{273}$ NEVES, M. 2009.Op. Cit. p. 104.

${ }^{274}$ No plano regional, para que surja uma Constituição (supranacional) capaz de servir à a uma racionalidade transversal com Estados-membros territorialmente divididos, é necessário que os sistemas político e jurídico estejam vinculado construtivamente mediante constituições transversais. In: NEVES. M. Op. cit. 2009. p. 100.

${ }^{275}$ MAGNETTE, Paul. Le régime politique de I'Union européenne. $2^{\circ}$ Editión. Paris: Presses de Sciences Po, 2006. p. 242

${ }^{276}$ COSTA, Olivier; SAINT MARTIN, Florent; Le Parlament européen. La Documentation Française, Paris, 2009. p.62.

${ }^{277} \mathrm{O}$ Tratado de Lisboa tem o objetivo de realizar as reformas necessárias as estruturas e ao funcionamento da União Europeia após a rejeição da Constituição Europeia, em 2007. As reformas são motivadas principalmente pelos sucessivos alargamentos do bloco. In: PIRIS, Jean-Claude. The Lisbon-Treaty: a legal and political analysis. Cambridge studies in European Law and policy. Cambridge, Reino Unido.

${ }^{278}$ KAELBLE, Hartmut. Les Chemins de la Démocratie Européenne. Paris: Editions Berlin, 2005. p. 116.
} 
O Parlamento Europeu começou como uma assembleia desprovida de competências relevantes, chamados de alguns de sem dentes, e gradualmente ganhou poder para se tornar a instituição de liderança e o motor da integração ${ }^{279}$.

Os parlamentos podem exercer uma contribuição válida e em tempo, por meio de uma gradual aquisição de poder e prestígio, tornar-se plenamente formada por mecanismos de integração com seu próprio direito. Eles também podem ser influências positivas no processo de cooperação e integração, facilitando a resolução de conflito e problemas, gerando metas e ideais para os próximos passos e ações como catalisadoras da construção de consenso $^{280}$.

Dessa forma, com o Tratado de Lisboa, o Parlamento Europeu torna-se mais próximo de um equivalente funcional de parlamentos nacionais, fazendo com que as normas autoaplicáveis tivessem um caráter não apenas de imposição, mas constitucionalmente democráticos, como um entrelaçamento transconstitucional entre ordens legislativas.

Atualmente é "o modelo mais avançado de parlamento de integração existente, parte da inédita institucionalidade concebida para a União Europeia, que pareceria reproduzir, em nível regional, ainda que imperfeitamente, a construção política presente no espaço público do Estado nacional"281.Com o Parlamento Europeu em posse de poderes, completa-se essa relação circular constitucional entre procedimentos legislativos, executivos e jurisdicionais, análogos ao modelo do constitucionalismo estatal.

Para observar esse entrelaçamento transconstitucional, propomos uma breve análise do caso da primeira aprovação de uma Diretiva após o Tratado de Lisboa, a Diretiva 2008/115, chamada de Diretiva de Retorno, que trata da política imigratória europeia. A percepção do processo legislativo e dos deputados europeus será o principal foco de análise.

\subsection{As Estruturas Supranacionais da União Europeia}

\footnotetext{
${ }^{279}$ STAVRIDIS, Stelios; PACE, Roderick. Regional Parliaments in the Euro-Mediterranean Region: does it amount to Integration? Garnet, Bordeaux, 24 March, 2010. p.13.

${ }^{280}$ STAVRIDIS, Stelios, 2010 Op. Cit. p.21

${ }^{281}$ DRUMMOND, Maria Claudia. O déficit democrático e as instituições parlamentares internacionais. In: Brasil, União Europeia, América do Sul: anos 2010 - 2020. Rio de Janeiro: Fundação Konrad Adenauer, 2009. p. 160-180. p. 163.
} 


\subsubsection{As mudanças a partir do Tratado de Lisboa}

O conceito de ordem de supranacional, levado à sério, consta apenas de uma organização que espelha de forma plena as funções do Estado: A União Europeia - UE. Progressivamente, a UE se organizou em tratados que atribuíram a seus próprios órgãos, competências de natureza legislativa, administrativa e jurisdicional abrangente no âmbito pessoal, material, territorial e temporal de validade, com força vinculante direta para os cidadãos e órgãos dos estados-membros, constitui, assim, a única experiência de supranacionalismo ${ }^{282}$.

O Tratado de Lisboa, que entrou em vigor em dezembro de 2009, é um dos chamados Tratados Constitucionais da União Europeia ${ }^{283}$. Como principais modificações pode-se conferir ampliação da participação do Parlamento Europeu no processo de co-decisão, reformular a ponderação de votos no Conselho e o número de cadeiras no PE. O Tratado de Lisboa também confere ao Parlamento uma maior participação técnica, ao alterar o Tratado da União Europeia associando sempre o Parlamento ao Conselho em todos os momentos que se referem ao processo decisório. ${ }^{284}$ Também conferiu uma maior participação dos próprios parlamentos nacionais ${ }^{285}$. Em conjunto com o maior peso do Parlamento Europeu, a participação dos parlamentos nacionais reforça a democracia e confere maior legitimidade ao funcionamento da União.

Essa estratégia buscou fortificar a esfera pública europeia e ajudar na construção de um povo constitucional, por meio de um uma ampla reforma do parlamento, fortificando o seu papel representativo e decisório. ${ }^{286}$ Um órgão legislativo-parlamentar relevante instigaria a articulação de uma esfera pública supranacional em torno dos seus procedimentos. Com a fortificação da representatividade democrática e do poder decisório do Parlamento Europeu, poderia estimular o desenvolvimento de uma esfera pública procedimentalmente relevante no

\footnotetext{
${ }^{282}$ NEVES. M. Op. cit. 2009. P.133

${ }^{283}$ Tratados Constitucionais anteriores: Tratado de Paris (1952); Tratado de Roma; (1957); Ato Único Europeu; (1986); Tratado de Maastricht (1992); Tratado de Amsterdã (1997); Tratado de Nice (2001) In: MEDEIROS, Marcelo de Almeida. União Européia, reformas institucionais e déficit democrático: uma análise a partir do mecanismo de co-decisão. Revista Brasileira de Política Internacional 52.1 2009.

${ }^{284}$ MEDEIROS, Marcelo de Almeida. União Européia, reformas institucionais e déficit democrático: uma análise a partir do mecanismo de co-decisão. Revista Brasileira de Política Internacional 52.1 2009.

${ }^{285} \mathrm{O}$ papel dos parlamentos nacionais será detalhado a seguir.

286 O povo constitucional diz respeito a capacidade de apoio político generalizado, no sentido da neutralização perante os particularismos e as persistentes pressões das relações concretas de dominação. In: NEVES. M. Op. cit. 2009. p. 97.
} 
plano europeu, que estaria em relação de complementaridade e concorrência com esferas públicas nacionais respectivas, no contexto de um sistema de níveis múltiplos entrelaçados. ${ }^{287}$

Devido a essa diferenciada concepção institucional, a relação entre pesos e contrapesos do poderes legislativo e executivo na União Europeia é diferente dos Estados nacionais. Nesse contexto da relação entre legislativo e executivo, o poder de assinar tratados internacionais em determinadas áreas é compartilhado entre o Conselho da União Europeia, o Parlamento Europeu e a Comissão Europeia, e ainda, sempre "autorizado" pelo Conselho Europeu.

Dessa forma, a capacidade de elaborar leis europeias, diretivas e regulamentos é distribuída conforme a competência de cada órgão, podendo aprovar, alterar ou rejeitar o conteúdo das leis europeias. Dois terços das leis europeias são adotadas conjuntamente pelo Parlamento Europeu e pelo Conselho, enquanto a Comissão Europeia detém o poder de iniciativa legislativa de toda ordem, interna ou de tratados internacionais.

Com o Tratado de Lisboa, o Conselho Europeu tornou-se uma instituição formalmente existente no âmbito da UE. É formado pelos presidentes e/ou os primeiros-ministros dos Estados-Membros, bem como o Presidente da Comissão Europeia, reunindo-se quatro vezes por ano, e, via de regra, delibera por consenso (art. 15, $\S \S 4^{\circ}$ e $5^{\circ}$ do Tratado de Maastricht).

O Conselho Europeu é um órgão que define prioridades e elabora estratégias políticas gerais para a União Europeia ${ }^{288}$. Segundo alguns autores ${ }^{289}$, é a instituição com maior poder na União Europeia.

A Comissão Europeia é o órgão executivo da UE. Além de elaborar propostas de nova legislação europeia, assegura a gestão corrente da aplicação das políticas e dos fundos da UE e representa os interesses desta no seu conjunto. Cabe-lhe, também, garantir que todos os países membros cumpram os Tratados e a legislação europeia ${ }^{290}$. Tradicionalmente, a Comissão Europeia detém o direito exclusivo de iniciativa legislativa formal, isto é, de agenda. Ainda que no campo de iniciativa política esse direito possa ter sido compartilhado com o Conselho Europeu, Parlamento Europeu e com a iniciativa popular ${ }^{291}$, uma novidade

\footnotetext{
${ }^{287}$ NEVES. M. Op. cit. 2009. p. 94.

288 Segundo o art. 15 do Tratado de Lisboa.

289 CEPS, EGMONT, EPC Joint Study. The Treaty of Lisbon: A second Look at the Institutional Innovations. Bruxelas, 2010.

${ }^{290}$ Comissão Europeia.

${ }^{291}$ Artigo 8.- B 4. "Um milhão, pelo menos, de cidadãos da União, nacionais de um número significativo de Estados-Membros, pode tomar a iniciativa de convidar a Comissão Europeia a, no âmbito das suas atribuições, apresentar uma proposta adequada em matérias sobre as quais esses cidadãos considerem necessário um ato jurídico da União para aplicar os Tratados.” In: Tratado de Lisboa.
} 
do Tratado de Lisboa ${ }^{292}$. O tratado também assegurou à Comissão um número de representantes iguais para cada Estado-membro. A legitimidade da Comissão está no fato de ter a habilidade de levar o interesse comum de todos os Estados-membros: "A Comissão promove o interesse geral da União e toma as iniciativas adequadas para esse efeito" ${ }^{293}$.

O Conselho da União Europeia ou Conselho de Ministros, ou apenas "Conselho", é composto por um representante de cada Estado-membro ao nível ministerial. O Conselho é o principal órgão de tomada de decisões da União Europeia. A função do Conselho é representar os Estados-membros no nível de decisão legislativa, tendo em vista que ele é competente para deliberar e votar sobre os projetos de atos legislativos ${ }^{294}$.

O Parlamento Europeu é o único órgão da União Europeia que resulta de eleições diretas desde 1979. Excepcionalmente, conta com 766 deputados. Em junho de 2009, 736 deputados foram eleitos. O Tratado de Lisboa, que entrou em vigor em dezembro de 2009, permitiu um adicional de 18 deputados que tomaram seus assentos em $1^{\circ}$ de Dezembro de 2011. Em $1^{\text {o }}$ de julho de 2013, após a adesão da Croácia à UE, 12 deputados croatas se juntaram ao Parlamento Europeu. Mas o número total de deputados será reduzido para 751, depois das eleições europeias de $2014^{295}$.

\subsubsection{A opção da União Europeia pela diplomacia parlamentar}

As inovações do Tratado de Lisboa trouxeram uma série de inovações, notadamente ao Parlamento Europeu, mas também aos parlamentos nacionais dos Estados-membros. Essa opção é corroborada pelos diversos artigos que são direcionados para as duas formas de Parlamentos. Assim, fica evidenciada uma crescente oportunidade, ao menos formal, para a diplomacia parlamentar ser atuante para além de sua função legislativa, mas também nas suas prerrogativas fiscalizadora e diplomática.

\footnotetext{
292 CEPS, EGMONT, EPC Joint Study. The Treaty of Lisbon: A second Look at the Institutional Innovations. Bruxelas, 2010. p. 51.

293 Art. $9^{\circ}$ - D.TRATADO DE LISBOA,

${ }^{294}$ LAGASSE, Charles-Étienne. Les institutions Européennes après le traité de Lisbonne. Bruxelas: Étidions Erasmus, 2010. p. 99-101.

${ }^{295}$ Essa readequação acontecer pelo fato do Tratado de Lisboa dar a alguns países lugares adicionais no PE pelo seu crescimento populacional, mas esses novos deputados foram incapazes de assumir seus postos no início da legislatura de 2009, pelo fato do Tratado de Lisboa ainda não haver sido ratificado. ARCHICK, Kristin. The European Parliament. Congressional Research Service.CRS. July 29, 2013. www.crs.gov Disponívelem<https://www.fas.org/sgp/crs/row/RS21998.pdf $>$ Acessoem 12/11/13.
} 
A participação dos parlamentos nacionais é garantida no Tradado, com os parlamentos nacionais tendo mais oportunidades de participar no trabalho da União ${ }^{296}$. "O Tratado de Lisboa consagra os Parlamentos nacionais como garante do bom funcionamento da UE (artigo 12..$^{\circ}$ TUE) e reconhece que os Governos são democraticamente responsáveis perante eles (artigo 10. ${ }^{\circ}$ TUE). ${ }^{297}$ Igualmente anexado ao Tratado, o Protocolo Sobre O Papel Dos Parlamentos Nacionais Na União Europeia concede obrigação de informação aos parlamentos de todos atos legislativos da Comissão, Conselho ou Parlamento Europeu. ${ }^{298}$ No mesmo Protocolo, é afirmado "definir em conjunto a organização e a promoção de uma cooperação interparlamentar eficaz e regular ao nível da União."299

Assim, o Protocolo privilegiou também as conferências interparlamentares de fiscalização e informação entre os órgãos. Dessa forma, foi fundada a "A Conferência dos Órgãos Especializados em Assuntos Comunitários" (COSAC), que envolve os órgãos especializados em assuntos da UE dos parlamentos nacionais e representantes do Parlamento Europeu. A COSAC reúne-se bianualmente. É composta por seis representantes de cada Parlamento nacional dos Estados-Membros e seis membros do Parlamento Europeu, dos quais dois são vice-presidentes responsáveis pelas relações com os parlamentos nacionais ${ }^{300}$. Além da cooperação parlamentar, o protocolo também obriga aos principais órgãos, Conselho, Comissão e Parlamento a manter os parlamentos nacionais informados de todos os atos legislativos $^{301}$.

\footnotetext{
${ }^{296}$ Temas e novos poderes dos Parlamentos Nacionais: Escrutínio do princípio da subsidiariedade; Espaço de Liberdade, Segurança e Justiça (Art. 71..$^{\circ}$ TFUE; (Art. 85. ${ }^{\circ}$ e 88. ${ }^{\circ}$, n. ${ }^{\circ} 2$ TFUE); Revisão dos Tratados; (art. 48. $\% 2$ a 5 TUE) o (art. 48.\% a 7 TUE); Pedidos de Adesão; (art. 49. ${ }^{\circ}$ TUE); Cláusula Passerelle; (Art. 81. ${ }^{\circ}$, n. ${ }^{3}$ TFUE); Cláusula de Flexibilidade. (art. 352. ${ }^{\circ}$ TFUE)

297 PORTUGAL. Assembleia da República. O TRATADO DE LISBOA E OS PARLAMENTOS NACIONAIS. Comissão de Assuntos Europeus. 2013

Disponível em <http://www.parlamento.pt/europa/PublishingImages/Documentos/TLx_PNs.pdf> Acesso em $11 / 11 / 13$.

${ }^{298}$ UNIAO EUROPEIA. PROTOCOLO RELATIVO AO PAPEL DOS PARLAMENTOS NACIONAIS NA UNIÃO EUROPEIA. Jornal Oficial da União Europeia. C 310/204. 16.12.2004.

${ }^{299}$ Art. $9^{\circ}$. In: PROTOCOLO RELATIVO AO PAPEL DOS PARLAMENTOS NACIONAIS NA UNIÃO EUROPEIA. Jornal Oficial da União Europeia. C 310/204. 16.12.2004.

${ }^{300}$ Além do COSAC, a cooperação entre o Parlemento Europeu e os Parlamentos Nacionais também é fomentada por dois institutos: o Centro Europeu de Investigação e Documentação Parlamentares (CERDP) e o Intercâmbio Interparlamentar de Informação sobre a União Europeia (IPEX). In: Disponível em <http://www.europarl.europa.eu/aboutparliament/pt/006d1cec56/Member-States'-national-parliaments.html> Acesso em 11/11/13.

${ }^{301}$ Art. $1^{\circ}$ : A Comissão envia diretamente aos Parlamentos nacionais os seus documentos de consulta (livros verdes, livros brancos e comunicações), a quando da sua publicação. A Comissão envia também aos Parlamentos nacionais, ao mesmo tempo que ao Parlamento Europeu e ao Conselho, o programa legislativo anual e qualquer outro instrumento de programação legislativa ou de estratégia política. Artigo 2. Os projetos de atos legislativos europeus dirigidos ao Parlamento Europeu e ao Conselho são enviados aos Parlamentos nacionais. Para efeitos do presente Protocolo, entende-se por "projeto de ato legislativo europeu" as propostas da Comissão, as iniciativas de um grupo de Estados-Membros, as iniciativas do Parlamento Europeu, os pedidos do Tribunal de Justiça, as recomendações do Banco Central Europeu e os pedidos do
} 
O Parlamento Europeu passa a decidir sobre a maior parte da legislação comunitária e a ter poderes sobre mais de quarenta novas áreas legislativas, incluindo a agricultura, a política energética e os fundos da UE, em codecisão com o Conselho. Compete ao Parlamento Europeu a aprovação final do orçamento da $\mathrm{EU}^{302}$. O Parlamento Europeu, nos moldes de parlamentos nacionais hodiernos, detém o poder de controle do executivo, poder legislativo e poder orçamental, os dois últimos em conjunto com o Conselho.

Isso faz com que o Parlamento Europeu se diferencie de qualquer outro parlamento extranacional: “Apenas um, o Parlamento Europeu, tem um verdadeiro poder legislativo, que desenvolve e aprova leis diretamente, embora não tenha poderes de soberania como um parlamento nacional, porque ele é um colegislador" ${ }^{303}$.

Em conjunto com o maior peso do Parlamento Europeu, a participação dos parlamentos nacionais reforçará a democracia e conferirá uma legitimidade acrescida ao funcionamento da União. Essa legitimidade vem suprir um déficit democrático das instituições europeias.

Assim, completa-se a circulação e contracirculação dos conceitos de sistema político, administração, política stricto sensu, público e povo no plano europeu, sendo possível esboçar a formação de uma ordem democrática supranacional em condições de vincular-se com a já consolidada ordem nacional, graças à constituição transversal entre política interna e direito interno europeu ${ }^{304}$. Assim, ao lado de um povo constitucional determinante dos procedimentos, impõe-se, para o surgimento e a estabilidade de uma Constituição supranacional transversal, a formação de uma esfera pública forte no plano regional, isto é, relevante para os procedimentos, que possa servir a abertura do sistema político ${ }^{305}$.

A circulação e contracirculação democrática na União Europeia conta com uma intensa interatividade das instituições da União Europeia, sendo compartilhadas as funções executivas entre o Conselho e a Comissão, e as funções legislativas entre as outras três instâncias. É importante considerar também o papel do Conselho Europeu, que projeta as

Banco Europeu de Investimento, que tenham em vista a adoção de um ato legislativo europeu. A Comissão envia os seus projeto de atos legislativos europeus diretamente aos Parlamentos nacionais, ao mesmo tempo que ao Parlamento Europeu e ao Conselho. O Parlamento Europeu envia os seus projetos de atos legislativos europeus diretamente aos Parlamentos nacionais. O Conselho envia os projetos de atos legislativos europeus emanados de um grupo de Estados-Membros, do Tribunal de Justiça, do Banco Central Europeu ou do Banco Europeu de Investimento aos Parlamentos nacionais. In: UNIAO EUROPEIA. PROTOCOLO RELATIVO AO PAPEL DOS PARLAMENTOS NACIONAIS NA UNIÃO EUROPEIA. Jornal Oficial da União Europeia. C 310/204. 16.12.2004

302 PARLAMENTO EUROPEU, 2012.

${ }^{303}$ PUIG, Lluis Maria de. Les parlaments internationaux. Editions Du Conseil de L'Europe. Strasbourg, 2008.p. 38.

${ }^{304}$ NEVES. M. Op. cit. 2009. p. 90.

${ }^{305}$ NEVES. M. Op. cit. 2009. p. 93. 
diretrizes gerais da União e, informalmente, joga um poderoso papel na rede institucional da União Europeia. Uma das mais importantes alterações trazidas pelo Tratado de Lisboa é incluir o Parlamento Europeu e o Conselho deliberando conjuntamente de acordo com o processo legislativo ordinário, adotando as medidas necessárias à execução da política de cooperação para o desenvolvimento, programas plurianuais de cooperação com países em desenvolvimento ou programas com uma abordagem temática ${ }^{306}$.

Assim, a generalização do apoio político (povo constitucional) pode ser considerada uma necessidade de legitimidade. A legitimidade regional remete a uma comunidade imaginária de mapas mentais, em que se sublinham algumas características e ignoram-se outras $^{307}$. Esse conceito pode ser aplicado a agrupamentos regionais na América Latina ou na Europa, pois, em ambas as regiões, os países têm estruturas ou códigos em comum, não necessariamente de valores. Não se trata de uma comunidade de valores, mas um povo institucionalizado que tem necessidades em comum.

No caso da Europa, as agendas regionais coincidem com os interesses regionais europeus, mas não necessariamente coincidem com os seus interesses globais. O Parlamento Europeu, assim, integra uma importante distribuição de poderes, que resulta em peça-chave para o fortalecimento do sistema da União Europeia, a partir de uma reciprocidade entre poder e legitimidade.

Com a necessidade de legitimidade, a ordem mundial está disposta de forma distinta, em que os cidadãos e os Estados precisam estar representados na distribuição de poderes, dentro de uma nova hierarquia: "A ordem mundial está estruturada com um tipo de hierarquia clara, invertida: indivíduos se juntam para formar um Estado, e os Estados, eventualmente, para formar um Estado federal; Estados centrais e federais juntam-se talvez para formar uma união (sub)continental." 308

Da perspectiva de uma ordem supranacional, os parlamentos regionais devem ser a fonte de legitimidade e representação a luz do regime democrático. Para saírem do plano exclusivamente simbólico, sua institucionalização necessita de poder legislativo. "É necessário que haja democracia: é inconcebível que onde haja igualdade jurídica e democracia política entrelaçadas, possa desenvolver-se com base em Estados autocráticos constituições simbólicas. „309

\footnotetext{
${ }^{306}$ UNIAO EUROPEIA, TRATADO DE FUNCIONAMENTO DA UNIAO EUROPEIA, 2009. art. 188 - E.

${ }^{307}$ HURRELL, Andrew. One world? Many worlds?The place of regions in the study of international society. InternationalAffairs 83: 1 (2007) 127-146

${ }^{308}$ HÖFFE, Otfried. A democracia no Mundo de Hoje. São Paulo, Martins Fontes, 2005. p. 507.

${ }^{309}$ NEVES. M. Op. cit. 2009. p.88.
} 
Embora esse aspecto normativo seja claro para a maior parte da literatura, ou seja, desejem-se instituições mais democráticas em todos os níveis, essa noção deixa de ser pacífica quando surgem críticas a respeito da própria possibilidade de democratização. Para Robert Dahl ${ }^{310}$, o conceito de democracia, independente dos níveis ou ordens, deve ser observado no mínimo em dois aspectos: como um sistema de controle popular sobre políticas e decisões governamentais, e como um sistema de direitos fundamentais. No primeiro caso, a participação popular por meio de eleições é a maneira mais prática de democracia, enquanto no segundo os direitos políticos e civis são os mais requeridos. Dessa forma: a democracia seria um sistema de controle popular sobre políticas e decisões governamentais" ${ }^{211}$. Isso acontece, segundo o autor, pela incapacidade do indivíduo de participar efetivamente no governo. Quanto maior o projeto democrático e quanto maior a gama de indivíduos que ele abarca, menor será sua capacidade de interação.

Entretanto, há posicionamentos indicando que o problema esteja mais no déficit institucional do que plano individual: "A política externa é uma política pública, haja vista que atores institucionais, sociais e econômicos a tratam nessa perspectiva; falta-lhe, porém, arcabouço institucional que reflita politicamente essa nova configuração."312 De forma análoga, Delmas-Marty $^{313}$ propunha um direito mundial como forma de realização da democracia e dos direitos humanos no plano internacional, pois, embora acredite que um governo mundial poderia ser capaz de lidar melhor com problemas de pobreza, fome, saúde, educação e meio ambiente, duvida da capacidade dos indivíduos de participar efetivamente dessa democracia com tendência à desaparição. ${ }^{314}$

Argumenta também que as pessoas não se interessam por políticas exteriores mesmo em países ampla e tradicionalmente democráticos. "É notoriamente difícil para cidadãos exercerem controle efetivo sobre muitas questões centrais em política externa" ${ }^{\text {315. Esse }}$

\footnotetext{
${ }^{310}$ DAHL, Robert. Can international organizations be democratic? A skeptics's view. In: Shapiro, Ian \& Hacker-Cordon, Casiano (eds.). Democracy's Edges. Cambridge University Press, 1999, pp. 19-40.

${ }^{311}$ DAHL, Robert. Can international organizations be democratic? A skeptics's view. In: Shapiro, Ian \& Hacker-Cordon, Casiano (eds.). Democracy'sEdges. Cambridge University Press, 1999, pp. 19-40. p. 22.

${ }^{312}$ MILANI, Carlos R. S.; PINHEIRO, Leticia. Política externa brasileira: os desafios de sua caracterização como política pública. Contexto int., Rio de Janeiro, v. 35, n. 1. p. 28.

${ }^{313}$ DELMAS-MARTY, Mireille. Três Desafios para um Direito Mundial. Tradução Fauzi Hassan Choukr. Rio de Janeiro: Editora Lumen Juris, 2003. p. 175.

${ }^{314}$ DAHL, Robert. Can international organizations be democratic? A skeptics's view. In: Shapiro, Ian \& Hacker-Cordon, Casiano (eds.). Democracy's Edges. Cambridge University Press, 1999, pp. 19-40. p. 23

${ }^{315}$ DAHL, Robert. Can international organizations be democratic? A skeptics's view. In: Shapiro, Ian \& Hacker-Cordon, Casiano (eds.). Democracy's Edges. Cambridge University Press, 1999, pp. 19-40. p. 24.
} 
argumento é corroborado na medida em que o índice de participação nas eleições do Parlamento Europeu tem diminuído progressivamente desde as eleições diretas de $1979^{316}$.

\subsection{O Entrelaçamento Legislativo da União Europeia}

O Parlamento Europeu conta com dois processos legislativos principais: o processo legislativo ordinário e o especial. O processo legislativo ordinário - antes chamado de codecisão - garante o mesmo poder ao Parlamento Europeu e ao Conselho num vasto leque de domínios, como, por exemplo, vistos, asilo e imigração (art. $78^{\circ}$ TFUE); cooperação

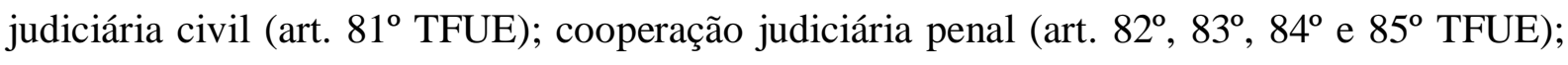
transportes marítimos e aéreos (art.100 TFUE); política monetária (art. 121.\% TFUE), e ainda meio ambiente e a proteção dos consumidores. O processo de codecisão foi introduzido pelo Tratado de Maastricht (1992) e depois ampliado e adaptado para reforçar a sua eficácia pelo Tratado de Amsterdã (1999). No Tratado de Lisboa, ele é novamente ampliado, tendo seu nome trocado para “processo legislativo ordinário'.

O processo legislativo especial - antes chamado de processo de consulta - aplica-se a casos específicos, em que o Parlamento apenas possui um papel consultivo. Com efeito, esses casos são justamente questões ditas sensíveis, como, por exemplo, a tributação, a política industrial e a política agrícola. Em certos casos, o Tratado prevê que a consulta seja obrigatória, e, assim, a proposta só adquire força de lei se o Parlamento tiver emitido um parecer $^{317}$.

Portanto, no âmbito da União Europeia, o poder legislativo, embora amplo e forte, é compartilhado entre o Conselho da União Europeia ${ }^{318}$ e o Parlamento Europeu. Dessa forma, a capacidade de elaborar leis europeias diretivas e regulamentos é distribuída conforme a competência de cada órgão, podendo aprovar, alterar ou rejeitar o conteúdo das leis europeias.

Os atos legislativos, a partir do Tratado de Lisboa, incluem os regulamentos, as diretivas e as decisões, conforme o Tratado de Funcionamento da União Europeia -TFUE (art.

\footnotetext{
${ }^{316}$ COSTA, Olivier; DRI, Clarissa."L’Union européenne peut-elle être démocratique? La participation aux élections au Parlement européen." Revista de estudos constitucionais, Hermenêutica e teoria do direito 2.12010.

${ }^{317}$ PARLAMENTO EUROPEU, 2012.

${ }^{318}$ O Conselho Europeu ou Conselho de Ministros é composto pelos Chefes de Estado ou de Governo, reúnese no máximo quatro vezes por ano e, via de regra, delibera por consenso. (art. $15, \S \S 4^{\circ}$ e $5^{\circ}$ do Tratado de Maastricht).
} 
$289)^{319}$. Os regulamentos têm um alcance geral, são obrigatórios em todos seus elementos e aplicáveis diretamente a todos os Estados-membros. A diretiva diferencia os Estadosmembros na eficácia temporal da obrigatoriedade, atendendo àqueles Estados que necessitem de uma transposição no corpo jurídico interno, oportunizando diferentes formas de transposição e determinando um prazo máximo para o início da vigência ${ }^{320}$. A diretiva é uma obrigação de resultado, não de meio.

Além do poder legislativo, o Parlamento Europeu dispõe de uma série de poderes de controle do executivo: poder de controle do domínio econômico e monetário ${ }^{321}$; controle democrático à Comissão; controle parlamentar sobre a atividade do Conselho; poder de censura à Comissão ${ }^{322}$; poder de nomear comissões de inquérito em caso de infrações ou de má aplicação do direito comunitário; poder de iniciativa política ${ }^{323}$; e poder de peritagem ${ }^{324}$.

E também a respeito do poder orçamentário, o Parlamento Europeu e o Conselho da União Europeia constituem a autoridade orçamentária da União Europeia que determina, todos os anos, as despesas e as receitas da União. Além disso, o Parlamento Europeu participa na execução e aprovação de despesas em caso de falta de orçamento ${ }^{325}$.

Portanto, no que diz respeito à diplomacia parlamentar no Parlamento Europeu, como foi afirmado acima, o Parlamento Europeu conta com 766 deputados, de 28 países diferentes, divididos em sete grupos políticos ${ }^{326}$. O Tratado de Lisboa conferiu a possibilidade da criação de partidos políticos internacionais, criados autonomamente ou a partir dos grupos políticos já existentes. ${ }^{327}$ Atualmente, o poder está distribuído entre os sete grupos políticos e número de deputados, conforme tabela abaixo:

\footnotetext{
${ }^{319}$ Tratado de Funcionamento da União Europeia, art. 289: O processo legislativo ordinário consiste na adoção de um regulamento, de uma diretiva ou de uma decisão conjuntamente pelo Parlamento Europeu e pelo Conselho, sob proposta da Comissão.

${ }^{320}$ SAURON, Jean-Luc. Le Parlement européen.Paris: Gualino éditeur, 2009, p.79.

${ }^{321}$ O Presidente, o Vice-presidente e os membros que compõem a Comissão Executiva do Banco Central Europeu têm de obter o aval do Parlamento antes de serem nomeados pelo Conselho. O Presidente do BCE apresenta o relatório anual perante o Parlamento Europeu em sessão plenária. (art. 283 TFUE)

${ }^{322}$ Trata-se de um direito fundamental de que dispõem os deputados europeus, afim de assegurar o controle democrático da União Europeia. (art. 234 TFUE).

${ }^{323} \mathrm{O}$ parlamento pode pedir à Comissão que submeta uma proposta ao Conselho da União Europeia. Convida regularmente a Comissão e o Conselho da União Europeia a desenvolverem políticas existentes ou a iniciar outras novas. (art. 289, $4^{\mathrm{a}}$ parte, TFUE)

${ }^{324}$ A Comissão deve submeter regularmente à apreciação do Parlamento diversos relatórios, como, por exemplo: relatório anual da Comissão sobre o funcionamento das Comunidades; relatório anual da aplicação do orçamento. (art. 319 TFUE)

${ }^{325}$ SAURON, Jean-Luc. Le Parlement européen. Paris: Gualino éditeur, 2009, p.104.

${ }^{326}$ Desde $1^{\circ}$ de Julho de 2013, o número de eurodeputados aumentou de 736 para 766.

${ }^{327}$ Conforme art. 224 do TFUE
} 


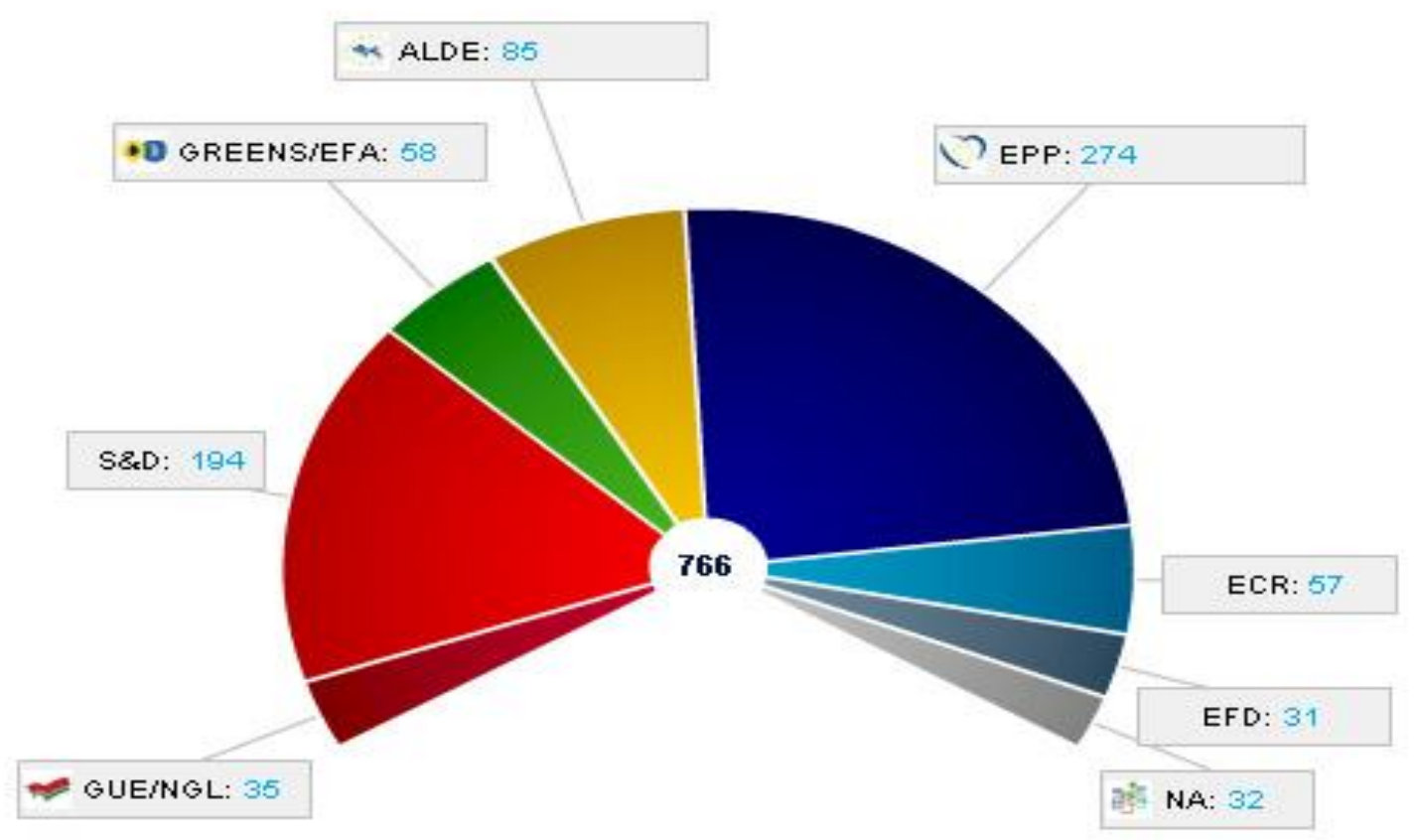

Fonte: $\operatorname{EPP}^{328}$

Atualmente, os grupos políticos são uma analogia aos partidos políticos em assembleias nacionais, assegurando a organização interna. Para constituir um grupo político é necessário um número mínimo de 25 deputados e uma representação de pelo menos um quarto dos Estados-Membros, sendo proibido aderir a mais do que um grupo político. Atualmente, os dois grupos políticos com maior representação são: "EPP” - Grupo do Partido Popular Europeu (Democratas-Cristãos), com 274 cadeiras, e o "S\&D” Grupo da Aliança Progressista Socialistas e Democratas do Parlamento Europeu, com 194cadeiras. Entretanto,

\footnotetext{
${ }^{328}$ As siglas estão em inglês, e se referem em ordem decrescente de representação aos seguintes grupos políticos: EPP 274 Group of the European People's Party (Christian Democrats) - Grupo do Partido Popular Europeu (Democratas-Cristãos); S\&D 194 Group of the Progressive Alliance of Socialists and Democrats in the European Parliament - Grupo da Aliança Progressista dos Socialistas e Democratas no Parlamento Europeu; ALDE 85 Group of the Alliance of Liberals and Democrats for Europe; Grupo da Aliança dos Democratas e Liberais pela Europa; GREENS/EFA 58 Group of the Greens/European Free Alliance - Grupo dos Verdes/Aliança Livre Europeia; ECR 57 European Conservatives and Reformists Group - Conservadores e Reformistas Europeus; 35 GUE/NGL Confederal Group of the European United Left - Nordic Green Left - Grupo Confederal da Esquerda Unitária Europeia/Esquerda Nórdica Verde; EFD 31 Europe of Freedom and Democracy Group - Europa da Liberdade e da Democracia; NA 32 - Não associados a nenhum grupo politico. *Os assentos da Croácia ainda não estavam agregados. Tabela original publicada Grupo do Partido Popular Europeu. Disponível em<http://www.eppgroup.eu/ep> Acesso em $01 / 12 / 13$.
} 
alguns deputados não pertencem a nenhum grupo político e, nesse caso, fazem parte dos "NA" - Não-inscritos.

A governança e a diplomacia parlamentar nacional estão amplamente ancoradas, pelo Regimento Interno do Parlamento Europeu, no seu art. 25, cujo item 5 promove e garante a participação da sociedade civil no debate de grandes temas do parlamento. Já o item 3 corresponde a uma grande preocupação do parlamento regional europeu em manter contato com os parlamentos nacionais, formando, assim, uma dupla diplomacia parlamentar.

O Parlamento Europeu se aproxima em muitos sentidos de um parlamento nacional. Contudo, diferentemente dos bancos centrais dos Estados europeus, que fazem parte da zona do euro e que foram destituídos em favor do Banco Central Europeu, os parlamentos nacionais ainda existem e mantêm seu relativo protagonismo em todas as matérias que não foram objeto de comunitarização ${ }^{329}$.

\subsubsection{A Iniciativa Legislativa}

A imigração associada à questão populacional é um dos grandes desafios do século $\mathrm{XXI}^{330}$. Embora o assunto nunca tenha saído de pauta, a imigração atualmente tem aspectos peculiares em cada região. Na Europa, as políticas de imigração são consideradas um ponto crucial na harmonização de normativas regionais, o que, segundo algumas autoridades europeias, evitaria a legislação à la carte desse tipo de situação, complementando, ainda, o Acordo Shengen (1985). Como plano de fundo, a imigração é um ponto chave para o futuro econômico da União Europeia.

A presente tese limita-se à análise formal do processo de elaboração legislativa da chamada Diretiva de Retorno aprovada pela União Europeia em dezembro de 2008. A controvertida Diretiva 2008/115 tem objetivo de dar início a política imigratória europeia:

\footnotetext{
${ }^{329}$ Dezessete países formam atualmente adotam o Euro como moeda única, o que se designa em conjunto como a zona do euro: Bélgica, Alemanha, Irlanda, Espanha, França, Itália, Luxemburgo, Países Baixos, Áustria, Portugal, Finlândia (em 1999), Grécia (em 2001), Eslovênia (em 2007), Chipre, Malta (em 2008), Eslováquia (em 2009) e Estônia (em 2011). In: COMISSÃO EUROPEIA. Assuntos Econômicos e Financeiros. O euro. Disponível em <http://ec.europa.eu/economy finance/euro/index_pt.htm>Acesso em: $10 / 10 / 13$

${ }^{330}$ Sobre imigração ver: BARALDI, C.; VENTURA, D. F. L.; ILLES, P. Proteção aos migrantes. In: Liliana Lyra Jubilut; Alexandre Gustavo Melo Franco Bahia; José Luiz Quadros de Magalhães. (Org.). Direito à diferença. 1ed. São Paulo: Saraiva, 2013, v., p. 441-462.; ILLES, P.; VENTURA, D. F. L.. Qual a política migratória do Brasil?. Le Monde Diplomatique (Brasil), São Paulo, SP, p. 34 - 35, 07 mar. 2012.
} 
“esta Diretiva, que constitui uma primeira etapa no sentido de uma política de imigração europeia, visa promover o regresso voluntário de imigrantes ilegais e estabelecer normas mínimas no que diz respeito ao período de detenção e à interdição de entrada na UE, bem como garantias processuais ${ }^{331}$."

A Diretiva 2008/115 foi aprovada em primeira leitura, com alterações do Parlamento Europeu. O que indica a importância da diplomacia parlamentar e o valor simbólico da segunda leitura. O Acordo de Schengen, de 1985, estipulou que a Comunidade Europeia, na época de sua adoção, deveria eliminar gradualmente o controle de barreiras internas, harmonizando a legislação sobre a política de concessão de vistos e medidas compulsórias. Em 1997, o Tratado de Amsterdam incorporou o Acordo de Schengen à União Europeia e obrigou todos os Estados-Membros a fazer parte de uma área de livre circulação de pessoas.

O Conselho Europeu de Tampere, em 1999, estabeleceu uma abordagem coerente no âmbito da imigração e do asilo, que tem por objeto a criação de um sistema comum de asilo, a política de imigração legal e a luta contra a imigração clandestina.

$\mathrm{Na}$ sua Comunicação relativa a uma política comum em matéria de imigração clandestina, de 15 de Novembro de 2001, a Comissão assinalou que a política de regresso é parte integrante e crucial da luta contra a imigração ilegal. A política de regresso deve ter por base três elementos: princípios comuns, normas comuns e medidas comuns. O Livro Verde, relativo a uma política comunitária em matéria de regresso, de 10 de Abril de 2002, considerou mais especificamente a questão do regresso como parte integrante de uma política comunitária global em matéria de imigração e de asilo ${ }^{332}$.

Com base na referida comunicação, o Conselho adotou o seu Programa de Ação em matéria de regresso de 28 de Novembro de 2002, buscando uma cooperação operacional mais eficaz entre Estados-Membros, um reforço da cooperação com países terceiros e o estabelecimento de normas comuns para facilitar o regresso dos imigrantes ilegais.

${ }^{331}$ COMISSÃO EUROPEIA: Dossier interinstitucional: 2005/0167 (COD) MIGR 41CODEC 750 COMIX 579 Data: 5 de setembro de 2005. <<http://register.consilium.europa.eu/pdf/pt/05/st12/st12125.pt05.pdf〉>

${ }^{332}$ O Livro Verde de 2002 foi o resultado da consulta das partes interessadas e avaliação do impacto relativo a uma política comunitária em matéria de regresso. Assim, foi lançado um projeto de amplo processo de consulta, incluindo uma audição pública, na qual participaram mais de duzentas pessoas e intervieram cercade trinta peritos. A audição permitiu que todas as partes interessadas tivessem a oportunidade de exprimir os seus pontos de vista e opiniões sobre as questões abrangidas pela presente proposta. Com base nas ideias apresentadas no Livro Verde, foram debatidas as práticas atuais em nível das políticas de regresso e as opções para uma futura política comum da UE em matéria de regresso de nacionais de países terceiros em situação irregular. In: COMISSÃO EUROPEIA: Dossiê interinstitucional: 2005/0167 (COD) MIGR 41CODEC 750 COMIX 579 Data: 5 de setembro de 2005. <<http://register.consilium.europa.eu/pdf/pt/05/st12/st12125.pt05.pdf $〉>$ 
O Programa da Haia, adotado pelo Conselho Europeu de 4 e 5 de Novembro de 2004, retomou esta questão e solicitou expressamente o estabelecimento de normas comuns para proceder ao repatriamento em condições humanas, com pleno respeito pelos direitos humanos e a dignidade das pessoas. Em 2005, o Comitê de Ministros do Conselho da Europa aprovou as "Vinte orientações sobre o regresso forçado" 333 , e, assim, o Conselho Europeu solicitou a apresentação de uma proposta da Comissão no início de 2005. Desde o início dos debates, há uma preocupação sobre os limites dessas regras em relação à dignidade da pessoa humana.

A função legislativa da União Europeia enseja uma intensa interatividade das suas instituições, especialmente o Conselho e a Comissão e o Parlamento Europeu. Por meio de uma análise formal dos procedimentos legislativos da União Europeia, com a análise de caso da Diretiva de Retorno 2008/115, espera-se visualizar a capacidade do Parlamento Europeu de influir na legislação europeia. No contexto da cooperação no domínio do regresso, a Diretiva 2003/110/CE do Conselho, de 25 de Novembro de 2003, relativa ao apoio em caso de trânsito para efeitos de afastamento por via aérea e a Decisão 2004/573/CE do Conselho, de 29 de Abril de 2004, relativa à organização de vôos comuns para o afastamento, representam os primeiros marcos jurídicos importantes.

A Diretiva 2001/40/CE do Conselho, relativa ao reconhecimento mútuo de decisões de afastamento de nacionais de países terceiros, em conjugação com a Decisão 2004/191/CE do Conselho, que estabelece os critérios e as modalidades práticas da compensação dos desequilíbrios financeiros decorrentes da aplicação daquela diretiva, prevê um quadro jurídico para o reconhecimento mútuo das decisões de afastamento.

No que diz respeito à dimensão financeira do regresso, a Comissão propôs a criação de um Fundo Europeu de Regresso para o período de 2008 a 2013, no âmbito do programa geral "Solidariedade e gestão dos fluxos migratórios"334.

A iniciativa legislativa na União Europeia está definida em várias possibilidades legais: a Comissão Europeia, iniciativas políticas do Conselho, do Parlamento e iniciativa popular. Historicamente, o Conselho autoriza a abertura das negociações, define as diretrizes de negociação, autoriza a assinatura e celebra os acordos.

No caso proposto, no dia 15 de Setembro de 2005, a iniciativa foi da Comissão Europeia, que enviou uma proposta concomitantemente ao Parlamento Europeu e ao

\footnotetext{
${ }^{333}$ COMISSÃO EUROPEIA: Dossier interinstitucional: 2005/0167 (COD) MIGR 41CODEC 750 COMIX 579 Data: 5 de setembro de 2005. <<http://register.consilium.europa.eu/pdf/pt/05/st12/st12125.pt05.pdf〉> ${ }^{334}$ [COM (2005) 123 de 6.4.2005].
} 
Conselho Europeu, chamado de "Normas e Procedimentos Comuns aos dos EstadosMembros para o Regresso de Nacionais de Países Terceiros em Situação Irregular" ${ }^{335}$.

Assim, a Comissão deu início ao trabalho de negociação a partir da solicitação do Conselho, como já foi relatado. A Comissão com a prerrogativa de fazer consultas à sociedade civil, assim o fez, promovendo o citado "Livro Verde" a respeito da matéria. ${ }^{336}$

No documento de proposta da Comissão, há uma exposição de motivos que ilustra o histórico de acontecimentos que envolvem a diretiva. Seu "objetivo teria sido o de responder a esse pedido e apresentar normas comuns claras, transparentes e equitativas em matéria de regresso, afastamento, recurso a medidas coercivas, prisão preventiva e readmissão, que têm em devida consideração o respeito pelos direitos humanos e as liberdades fundamentais das pessoas em causa" 337 .

O "retorno", no contexto daquele documento refere-se a pessoas em situação irregular na UE. Estas pessoas não preenchem, ou deixaram de preencher, as condições para a entrada, permanência ou residência em os territórios dos Estados-Membros da União Europeia, porque entraram ilegalmente, porque perderam a sua autorização de residência, ou porque o seu pedido de asilo foi finalmente rejeitado ${ }^{338}$. Nacionais de países terceiros são aqueles que não preenchem ou deixaram de preencher as condições de entrada em conformidade com a Convenção de Aplicação do Acordo de Schengen - um ato baseado no acervo de Schengen ou de algum modo com ele relacionado, na acepção do n. ${ }^{\circ} 2$ do artigo 3. ${ }^{\circ}$ do Ato de Adesão ${ }^{339}$.

\subsubsection{Debate e aprovação Legislativa}

Após a iniciativa, Conselho e Parlamento dão início às discussões, embora já haja conhecimento da matéria, informalmente, por ambas instituições. Em conformidade com a declaração comum sobre as regras práticas do processo legislativo ordinário, realizaram-se diversos contactos informais entre o Conselho, o Parlamento Europeu e a Comissão a fim de chegar a um acordo em primeira leitura. Caso fosse necessário, tanto o Parlamento Europeu quanto o Conselho poderiam fazer emendas ao texto.

\footnotetext{
335 COMISSÃO EUROPEIA: Dossier interinstitucional: 2005/0167 (COD) MIGR 41CODEC 750 COMIX 579 Data: 5 de setembro de 2005. <<http://register.consilium.europa.eu/pdf/pt/05/st12/st12125.pt05.pdf〉>

${ }^{336}$ COMISSÃO EUROPEIA, 2005. Op. Cit.

${ }^{337}$ COMISSÃO EUROPEIA, 2005. Op. Cit.

${ }^{338}$ COMISSÃO EUROPEIA, 2005. Op. Cit.

${ }^{339}$ COMISSÃO EUROPEIA, 2005. Op. Cit.
} 
A Comissão das Liberdades Cívicas, da Justiça e dos Assuntos Internos do Parlamento Europeu propôs 260 emendas à proposta inicial, reunidas no Relatório apresentado pelo deputado Manfred Weber - Grupo do Partido Popular Europeu (Democratas-Cristãos).

Com as suas alterações, o relator deseja, nomeadamente, reforçar o papel do Parlamento enquanto defensor dos direitos humanos e da humanidade. Por isso, o relator procurou conferir ao procedimento de regresso uma dimensão humanitária, e isto, superando também as normas previstas na proposta da Comissão. Por isso, o relator propõe nas suas alterações uma definição de "zona de trânsito". Deste modo, deverá pôr-se cobro a uma definição arbitrária, propiciadora da criação de espaços não regidos pelo direito ${ }^{340}$.

Os temas modificados pelas emendas do Parlamento também abrangem outras áreas: período máximo de detenção; disposições mais favoráveis; o melhor interesse da criança; proibição de reentrada: em princípio, ser superior a cinco anos ${ }^{341}$. Verifica-se que algumas alterações, mesmo que tímidas, foram significativas e alteraram a proposta inicial positivamente para os direitos humanos, como a que diz respeito a detenção, em que uma série de alterações foram realizadas, como destaca o relator: os Estados-Membros só podem manter detidos nacionais de países terceiros que estão sujeitos a procedimentos de regresso, a fim de preparar o regresso e/ou realizar o processo de afastamento, nomeadamente quando há um risco de fuga ou quando a pessoa em causa evitar ou entravar a preparação do retorno ou o processo de remoção ${ }^{342}$.

Contudo, sobram críticas e espantos quando se depara com certas declarações oficiais: "A diretiva torna claro que os clandestinos devem abandonar a Europa. Não é, de resto, tarefa

\footnotetext{
${ }^{340}$ Parlamento Europeu. Comissão das Liberdades Cívicas, da Justiça e dos Assuntos Internos. Relator: Manfred Weber PROJECTO DE RELATÓRIO. EXPOSIÇÃO DE MOTIVOS. 13.6.2006. (COM(2005)0391 - C6-0266/2005 - 2005/0167(COD)).

${ }^{341}$ EUROPEAN PARLIAMENT. Legislative Observatory.2005/0167(COD) - 18/06/2008 http://www.europarl.europa.eu/oeil/popups/summary.do?id=1040487\&t=d\&l=en

${ }^{342}$ A detenção será para um período tão curto quanto possível e só será mantida enquanto o procedimento de afastamento estiver pendente e for executado com a devida diligência. Quando a detenção tenha sido ordenada por autoridades administrativas, os Estados-Membros: i) prever um controle jurisdicional célere (menos de 48 horas) da legalidade da detenção, a decidir o mais rapidamente possível, a partir de do início da detenção, ou ii) ou conceder o nacional de um país terceiro em causa o direito de intentar uma ação através da qual a legalidade da sua detenção seja sujeito a um controlo jurisdicional célere, a decidir o mais rapidamente possível a partir do lançamento do respectivo procedimento, neste caso os Estados-Membros devem informar imediatamente o país terceiro em causa nacional sobre a possibilidade de apresentar tal pedido. In: EUROPEAN PARLIAMENT. Legislative Observatory. 2005/0167(COD) - 18/06/2008

http://www.europarl.europa.eu/oeil/popups/summary.do?id=1040487\&t=d\&l=en
} 
da presente diretiva verificar a situação de clandestinidade, mas apenas garantir um processo de repatriamento transparente." 343

Com esse tom, o Parlamento Europeu emitiu o parecer em primeira leitura em 3 de Setembro de 2008, tendo aprovado alteração à proposta da Comissão ${ }^{344}$. Para adotar a decisão sobre o tratado, é necessária a aprovação no Parlamento Europeu. Apenas após a aprovação no Parlamento é possível a adoção do tratado pelo Conselho.

$\mathrm{Na}$ votação que teve lugar em Estrasburgo, os eurodeputados apoiaram as alterações de compromisso apresentadas pelo grupo PPE/DE (partido político do relator, Manfred Weber). Das 260, 45 alterações(emendas) propostas foram aprovadas. ${ }^{345}$ As alterações foram aprovadas por 367 votos a 206, com 109 abstenções. De acordo com o relator elas são resultado de um compromisso alcançado com o Conselho em primeira leitura

As alterações apresentadas pelos grupos PSE, Verdes/ALE e CEUE/EVN não obtiveram os votos necessários, tendo acontecido o mesmo com as alterações que propunham a rejeição total da diretiva.

$\mathrm{Na}$ votação dessa diretiva, tivemos uma cooperação não usual entre os dois maiores grupos de partidos: os Democratas Cristãos, de direita, e os Socialistas, de esquerda. A razão principal dessa cooperação é a própria dinâmica de votação em turnos. No primeiro turno é necessária apenas a maioria dos deputados, no segundo é necessária a maioria de todo o parlamento $^{346}$.

Se o Parlamento não o tivesse aprovado em primeira leitura, o texto retornaria à Comissão Europeia que poderia refazer a proposta e novamente apresentá-la ao Parlamento, o que constitui a "segunda leitura". Aprovado o texto, o PE o envia para o Conselho. Se o Conselho aprová-lo, torna-se lei, um ato normativo obrigatório a todos Estados-membros.

Se o Conselho ou Parlamento Europeu não aprovam um texto em sua segunda leitura, há uma reunião na qual Parlamento Europeu, Conselho e a Comissão Europeia são chamados a uma terceira e última leitura de proposição. Havendo acordo, a lei é adotada.

\footnotetext{
${ }^{343}$ Parlamento Europeu. Comissão das Liberdades Cívicas, da Justiça e dos Assuntos Internos. Relator: Manfred Weber PROJECTO DE RELATÓRIO. EXPOSIÇÃO DE MOTIVOS. 13.6.2006. (COM(2005)0391 - C6-0266/2005 - 2005/0167(COD)).

344 CONSELHO DA UNIÃO EUROPEIA. Dossier interinstitucional: 2005/0167 (COD) CODEC 1630 MIGR 119 COMIX 856. Data: 2 dezembro de 2008.

$\langle<$ http://register.consilium.europa.eu/pdf/pt/08/st16/st16166-re01.pt08.pdf $\rangle$

345 Parlamento Europeu. Comissão das Liberdades Cívicas, da Justiça e dos Assuntos Internos. Relator: Manfred Weber PROJECTO DE RELATÓRIO. EXPOSIÇÃO DE MOTIVOS. 13.6.2006. (COM(2005)0391 - C6-0266/2005 - 2005/0167(COD)).

346 PEERS, Steve. StatewatchAnalisys. Junho 2008.<http://www.detention-ineurope.org/images/stories/june\%202008\%20statewatch\%20analysis\%20on\%20return\%20directive.pdf>
} 
Depois de aprovada a diretiva, os Estados-Membros tiveram 24 meses, contados após a data de publicação da diretiva no Jornal Oficial da UE para transpô-la para o direito nacional, prazo que se encerrou em 24 de dezembro de 2001. No caso das regras relativas à assistência jurídica, o prazo de transposição é de 36 meses. Após a assinatura do ato legislativo pelo Presidente do Parlamento Europeu, pelo Presidente do Conselho e pelos Secretários-Gerais de ambas as instituições, o ato legislativo é publicado no Jornal Oficial da União Europeia $^{347}$.

Contudo, nem todos os Estado fizeram a transposição de suas normas a tempo: Áustria, Bélgica, Chipre, Alemanha, Lituânia, Polônia, Suécia e Holanda não comunicaram à Comissão Europeia, um dever de cada país, as medidas nacionais de transposição da Diretiva Retorno de 2008/115. Os Estados-Membros eram obrigados a transpor as disposições da diretiva até final de $2010^{348}$. Os membros não cooperaram mesmo após uma carta solicitando explicações da Comissão em setembro de 2011.

As políticas do processo de tomada de decisões da UE têm um impacto limitado na fase de adaptação em nível nacional. Entre os fatores no plano da UE, um papel mais importante é desempenhado pela qualidade jurídica das diretivas. Assim, em vários casos ocorreram problemas de transposição porque as disposições subjacentes foram redigidas vagamente ou por falta de clareza e consistência ${ }^{349}$.

Esta é a primeira de três diretivas sobre uma política comum de imigração a ser submetida à votação do plenário. As demais foram a proposta de diretiva que estabelece sanções contra os empregadores de imigrantes ilegais e a proposta relativa às condições de entrada e de residência de nacionais de países terceiros para efeitos de emprego altamente qualificado.

A visualização das fases do processo legislativo reafirma que, após o Tratado de Lisboa, com os novos poderes conferidos às instituições europeias, forma-se uma estrutura de freios e contrapesos, na qual o Parlamento Europeu desempenha um papel importante na tentativa de suprimir déficit democrático, por meio de poderes e representação direta dos parlamentares europeus.

347 CONSELHO DA UNIÃO EUROPEIA. Dossier interinstitucional: 2005/0167 (COD) CODEC 1630 MIGR 119 COMIX 856. Data: 2 dezembro de 2008. $\langle<$ http://register.consilium.europa.eu/pdf/pt/08/st16/st16166-re01.pt08.pdf 〉>

348 EUROPA - PRESS RELEASES - Press Release - An effective and humane return policy: 8 Member States have yet to comply with the Return Directive. Disponível em <<europa.eu/rapid/press-release_IP-111097_en.htm >>

${ }^{349}$ WAHL, Peter. "No, they can't!" The potential and limitations of the EU (as a supranationalstate in the making) to reform finance and overcome the crisis. PSL Quarterly Review, vol. 65 n. 263. 2012. 403-427. 
Uma vez que o Parlamento Europeu preenche o papel de diplomacia parlamentar eleita com função legislativa, o elemento de participação dos parlamentares é um critério de desempenho democrático do sistema. Embora haja um novo e despretensioso papel dos parlamentos nacionais, na medida em que as normas aprovadas são autoaplicáveis, esvazia-se seu papel de função legislativa em relação às matérias que foram objeto de norma supranacional.

Não obstante, o sistema de normas autoaplicáveis não funciona sem coações e fiscalizações. Todas as transposições de diretivas até hoje sofreram resistências. Isso demonstra que o entrelaçamento entre as ordens ainda não é automático e conta com problemas de execução. Contudo, ainda assim, a estrutura institucional europeia proporciona uma caso concreto de transconstitucionalismo, uma vez que a diplomacia parlamentar tem legitimidade e força para interferir na elaboração das normas supranacionais. 


\section{OS ENTRELAÇAMENTOS DE ORDENS LEGISLATIVAS TRANSANACIONAL/NACIONAL: O EQUIVALENTE FUNCIONAL LEGISLATIVO DO CASO FIFA/BRASIL}

A diplomacia parlamentar eleita com função legislativa é realizada por parlamentares legitimados direta ou indiretamente por eleições. Seu envolvimento no processo legislativo irá depender das competências que lhes são conferidas pela constituição nacional. As ordens legislativas nacionais geralmente envolvem o Parlamento no debate post factum, restringindo ao poder à aprovação ou rejeição de atos internacionais e subsequente incorporação ao âmbito doméstico. Isso poderia parecer comum, mas é condicionado diferentemente frente a ordens legislativas atípicas, como a ordem jurídica-política transnacional.

Portanto, essa diplomacia parlamentar no âmbito nacional tem uma estreita relação com a evolução política constitucional. No Brasil, a consolidação de suas competências também é reflexo da luta política entre os três poderes, estabilizada nas estruturas constitucionais de cada época. No entanto, o ambiente internacional pressiona e motiva mudanças nessas relações. A crescente notoriedade dos temas internacionais para o Brasil e a consolidação de diferentes ordens extranacionais no mundo submetem o ator parlamentar ao âmbito internacional. Em especial a lex sportiva, a ordem transnacional do esporte, tem gerado expectativas contraditórias: do prestígio da ideia de megaeventos, como a Copa do Mundo e Olimpíadas, à imputação de desrespeito a direitos.

Essas contradições são denunciadas por vozes difusas de blogs, jornais e redes sociais. ${ }^{350}$ Há preocupação de variadas naturezas com respeito às competições realizadas pela

\footnotetext{
${ }^{350}$ VARELLA, Guilherme. Copa sem direitos não dá jogo. Carta Capital. 11/10/2011. Disponível em:<www.cartacapital.com.br/politica/a-lei-geral-da-copa-cria-um-estado-de-excecao-em-relacao-a-defesado-consumidor>Associações Nacionais: Copa Comitê Popular da Copa, Disponível em: swww.portalpopulardacopa.org.br/>; Instituto Brasileiro de Defesa do Consumidor <www.idec.org.br/campanhas/copasemdireitos>; Comitê Popular dos Atingidos pela Copa 2014. $<$ http://atingidoscopa2014 wordpress.com/>; Projeto Jogos impos
} 
FIFA no Brasil em 2013 e 2014, a Copa das Confederações e a Copa do Mundo. Esses receios são diferentes entre si, mas giram em torno da violação de direitos, do questionamento sobre reais ganhos econômicos para a sociedade e da exagerada exceção jurídica e política concedida à FIFA.

Contudo, verifica-se que a maioria das denúncias e especulações não são propostas como hipótese e problema de pesquisa. Isso ocorre principalmente pela dificuldade de obtenção de informações oficiais. Nesse contexto, por exemplo, nenhum dos documentos entre Brasil e FIFA estão disponíveis para o público. O governo brasileiro mantém diversos websites oficiais sobre o evento: Transparência da Copa ${ }^{351}$, Portal da Copa ${ }^{352}$, Gecopa/Agu ${ }^{353}$, Tribunal de Contas da União ${ }^{354}$. Estados federados e municípios ${ }^{355}$ possuem portais de transparência da Copa, os quais proporcionam apenas a visualização e publicidade das obras em andamento, no entanto, não divulgam os documentos oficiais sobre o evento, ou contratos entre Governo, patrocinadores e Copa do Mundo. Websistes da FIFA ${ }^{356}$ ou da $\mathrm{CBF}^{357}$ também não o fazem. Fazem o contrário: todas essas informações são dificultadas, sonegadas ou burocratizadas, isto é, utiliza-se apenas retoricamente de um discurso de transparência ${ }^{358}$.

As implicações da ordem jurídica transnacional do futebol não são triviais. No âmbito desta tese, o futebol é considerado como um bem comum público. Essa característica, por si, já lhe confere um status de objeto de debate político e público sobre as regras que o regem. Contudo, a ingerência de uma organização privada com abrangência mundial como a FIFA em países democráticos e soberanos demonstra ter também reflexos econômicos e jurídicos.

\footnotetext{
$<$ http://www.jogoslimpos.org.br>Associações Locais da Copa: São $\quad$ Paulo: <comitepopularsp.wordpress.com/>Porto Alegre: <http://comitepopularcopapoa2014.blogspot.com.br/> Rio de Janeiro: <comitepopulario.wordpress.com/>; Curitiba: <copa2014curitiba.wordpress.com>; Recife: $<$ comitepopularpe.wordpress.com/> Acessos em 23/10/2013.

${ }^{351}$ BRASIL. Portal da Transparência. Disponível em: <www.portaltransparencia.gov.br/copa2014>. Acesso em 20/09/2013.

${ }^{352}$ BRASIL. Portal da Copa. Disponível em: 〈http://www.copa2014.gov.br/>. Acesso em 20/09/2013.

353 BRASIL. Advocacia Geral da União. Disponível em: plateTexto.aspx?idConteudo= 181043\&id_site=1104\&ordenacao=1> Acesso em 21/08/2013.

354 BRASIL. Fiscalização da Copa 2014 do TCU - Disponível em: <http://portal2.tcu. gov.br/portal/page/portal/TCU/copa2014> Acesso em 25/08/2013.

355 Acesso em 20/08/2013; Governo do Estado do Paraná. Disponível em: <http://www.copa2014.pr.gov.br/> Acesso em 23/07/2013; Governo do Estado de São Paulo. Disponível em: <http://www.copa2014.sp.gov.br/> Acesso em 23/08/2013; Prefeitura Municipal de Belo Horizonte. Disponível em: <http://portalpbh.pbh.gov.br/pbh/ecp/comunidade.do?app=transparenciacopa2014> Acesso em 25/07/2013; Prefeitura Municipal de Natal. Disponível em:<http://www.copa2014.natal.rn.gov.br/> Acesso em 27/07/2013; Prefeitura Municipal de Porto Alegre. Disponível em: <http://www.transparencianacopa.com.br/> Acesso em 03/07/2013; Prefeitura Municipal de Recife. Disponível em: <http://www.secopa.recife.pe.gov.br/> Acesso em 23/09/2013.

${ }^{356}$ FIFA - Federação Internacional de Futebol. Disponível em: <www.fifa.com> Acesso em: 20/09/2013.

${ }^{357}$ CBF. Confederação Brasileira de Futebol. Disponível em: <www.cbf.com.br> Acesso em 20/11/2013.

${ }^{358}$ A exemplo dessa afirmação, será a descrição desse capítulo ao acesso às Garantias do Brasil dadas a FIFA.
} 
Com o poder de barganha que deriva da prerrogativa de administrar megaeventos e gerar recursos financeiros grandiosos, a FIFA, que não se submete a qualquer tipo de fiscalização pública ou órgão democrático, alcança um grande sucesso em se valorizar.

O objetivo do estudo de caso do presente capítulo será explorar o entrelaçamento transconstitucional da ordem legislativa transnacional e ordem legislativa nacional. Para tanto, é proposto inicialmente um debate em torno da natureza de ordem legislativa transnacional, repleta de propriedades distintas da ordem nacional, embora fortemente adaptada aos novos paradigmas da globalização. O processo legislativo nacional é estruturado pela constituição nacional e pela atuação política da diplomacia parlamentar.

Como argumento central, o objetivo é analisar transconstitucionalmente a relação entre a FIFA - Fédération Internationale de Football Association - e o Brasil no estabelecimento da nova legislação, notadamente, a Lei Geral da Copa, para as Competições $^{359}$ da Copa das Confederações de 2013 e a Copa do Mundo de 2014. Com isso, pretende-se demonstrar o entrelaçamento da ordem transnacional com a outra, nacional, havendo tido a FIFA o poder de iniciativa legislativa na Lei Geral da Copa.

Serão utilizadas fontes de pesquisa primárias e secundárias. Dentre as fontes primárias, destacam-se os documentos: Form of Hosting Agreement e o Bidding Agreement ${ }^{360}$ (Protocolo de Garantias), debates das audiências da Comissão Especial para Lei Geral da Copa, Emendas propostas e discursos dos parlamentares no Plenário. O Protocolo de Garantias, ao qual a população não tem acesso e que conta com restrições às instituições públicas e ao Congresso Nacional, será o equivalente funcional de iniciativa legislativa no entrelaçamento entre o Brasil e a FIFA.

A interação do Poder Legislativo nos processos de negociação dos tratados internacionais é decorrente dos ideais democrático-liberais, consolidados a partir do final do século XIX. Nesse período, surgem dois principais sistemas de controle de atos internacionais pelo Legislativo, a Constituição dos Estados Unidos da América e a Constituição Belga, que será adotada pela França, posteriormente ${ }^{361}$.

Há exemplos clássicos, e outros novos, desse tipo específico de diplomacia parlamentar em questões internacionais. Em 1919, o Senado dos Estados Unidos da América

\footnotetext{
359 Segundo o Form of Hosting Agreement da FIFA, o termo Competições é associado aos dois eventos "Copa do Mundo 2014" e "Copa das Confederações 2013”.

${ }^{360}$ Esses documentos serão descritos com maior precisão no subcapítulo seguinte. Contudo, para efeito de compreensão do texto, serão chamados de Protocolo de Garantias.

361 CACHAPUZ DE MEDEIROS, Antônio Paulo. O poder de celebrar tratados. Competência dos poderes constituídos para a celebração de tratados, à luz do Direito Internacional, do Direito Comparado e do Direito Constitucional Brasileiro. Porto Alegre, Sergio Antonio Fabris Editor, 1995. pp. 40-107.
} 
não aprovou o tratado constitutivo da Liga das Nações, proposto pelo próprio presidente americano, Woodrow Wilson. "No seu discurso perante o Senado, em 1917, Wilson afirmou que o estabelecimento de direitos iguais entre Estados seria um preceito necessário para a manutenção da paz por meio da segurança coletiva, independentemente do poder de cada nação representada." 362

Outros países tiveram pouca fé no que estariam fazendo. Enquanto pregavam a paz se preparavam para a guerra, pois não se poderia esperar sucesso de um programa de desarmamento bem sucedido, enquanto os Estados Unidos não tivesse nenhuma participação. A partir de então, outras nações, ao colocarem seus planos para uma ordem mundial, tiveram que escolher não o que eles acham que é desejável, mas o que eles acham que a situação política na América permitirá o Senado a aceitar ${ }^{363}$.

Com essa negativa, o país nunca se tornou membro da organização internacional. A recém-formada Liga das Nações nasce avariada, quando o Senado dos Estados Unidos da América não aprovam a entrada do país na nova organização.

Outro exemplo mais recente e polêmico envolve o MERCOSUL. Em 4 de julho de 2006, o Protocolo de Adesão da Republica Bolivariana da Venezuela ao MERCOSUL foi aprovado de forma unânime pelos quatro países membros. Dando sequência ao trâmite legal, o Protocolo foi enviado a suas respectivas casas parlamentares para aprovação definitiva.

Enquanto na Argentina e Uruguai a votação nos respectivos parlamentos foi imediata e positiva, no Brasil e no Paraguai a discussão parlamentar foi intensa ${ }^{364}$ : O Senado brasileiro foi palco dos debates mais acirrados, com manifestações radicais, tais como as declarações dos senadores Gerson Camata (PMDB-ES) e Marisa Peirano (PSDB-MS) em favor de expulsar a Venezuela do MERCOSUL ${ }^{365}$. Ao mesmo tempo, houve atitudes conciliadoras, como do senador Eduardo Suplicy (PT-SP), que sugeriu o convite a deputados venezuelanos

\footnotetext{
${ }^{362}$ KISSINGER, Henry A. Diplomacy. New York: Simon and Schuster, 1994. P. 227.

${ }^{363}$ BAILEY, Thomas Andrew. Woodrow Wilson and the great betrayal. Macmillan, 1945.

364 O Uruguai promulgou o Protocolo no dia 06 de Novembro de 2006, que passou no Senado e por último na Câmara de Deputados, Lei 18.053. In: URUGUAI, Lei 18.053. A aprovação foi alvo de críticas por deputados oposicionistas, como o Deputado do Partido Tradicional, Jaime Trobo, que declarou: "Ou não querem discutir ou há uma pressão indevida do exterior para o Uruguai". In: A Argentina aprovou o Protocolo no Congresso no dia 6 de dezembro de 2006, por unanimidade no Senado e por 160 votos favoráveis e 12 contra, na Câmara de Deputados, Lei 26.192. In: ARGENTINA, Congresso Nacional. Lei 26.192.; Periodico Perfil: 〈http://www.perfil.com/ internacional/-20061102-0064.html>Acesso em 25 de outubro de 2013. El Economista.Parlamento argentino apruebaelingreso de Venezuela al Mercosur . España. <http://www.eleconomista.es/empresas-finanzas/noticias/ 115303 /12/06/Parlamento-argentino-aprueba-elingreso-de-Venezuela-al-Mercosur.html; > Adn Mundowww.adnmundo.com/contenidos ii regional/pralam uruguay ven mercos_ir 06 11_03.html Acesso em 10 de setembro de 2013.

${ }^{365}$ SANTOS, Fabiano; VILAROUCA, Márcio. Adesão da Venezuela ao Mercosul: Des-ideologizar como forma de atingir o Interesse Nacional. Papéis Legislativos. n.4. 2007. P.6
} 
para que viessem ao Brasil, e do senador Mão Santa (PMDB-PI) sugerindo o movimento contrário, que uma delegação brasileira fosse a Caracas. ${ }^{366}$ Ao final, as delegações parlamentares reuniram-se apenas com os serviços diplomáticos, encaminhando a aprovação do Protocolo ${ }^{367}$.

Ao contrário, no Paraguai, a discussão foi levada à votação duas vezes durante o governo de Fernando Lugo, sendo rejeitada na primeira e retirada de pauta na segunda. A situação é agravada com o golpe de Estado de 2012 e a deposição do presidente ${ }^{368}$.

A ruptura democrática do Paraguai foi punida pelos países parte do Mercosul, seguindo as prerrogativas do artigo $6^{\circ}$ do Protocolo de Ushuaia (II) ${ }^{369}$."O Protocolo de Ushuaia é muito claro. Se um país membro do MERCOSUL adota um regime nãodemocrático, este país deve ser excluído desta organização de integração regional." 370 Dentre outras alternativas que podem ser adotadas para violação da cláusula democrática, está a suspensão do país parte, revogando o seu direito de participar dos órgãos estruturais que compõem a organização. Por esse motivo, no dia 29 de junho de 2012, Argentina, Brasil e Uruguai anunciam a suspensão do Paraguai do MERCOSUL até abril de $2013^{371}$. No mesmo ato e imediatamente, declaram a admissão da Venezuela ao MERCOSUL ${ }^{372}$.

Mesmo suspenso do MERCOSUL, o Senado paraguaio volta a votar e rejeitar a entrada da Venezuela no bloco em 23 de agosto de 2012 373 . "Mesmo sendo rejeitado pela

\footnotetext{
${ }^{366}$ SANTOS, Fabiano; VILAROUCA, Márcio. Adesão da Venezuela ao Mercosul: Des-ideologizar como forma de atingir o Interesse Nacional. Papéis Legislativos. n.4. 2007.

${ }^{367}$ O Plenário do Senado finalmente aprovou, por 35 votos a 27. O Congresso Brasileiro aprovou definitivamente o referido Protocolo, por meio do Decreto Legislativo № 934, de 16 de dezembro de 2009. In: BRASIL, Decreto Leg. 934/2009. In: Agência Senado. Aprovado protocolo que inclui a Venezuela no Mercosul. Disponível em: 〈http://www12.senado.gov.br/noticias/materias/2009/12/15/aprovado-protocoloque-inclui-a-venezuela-no-mercosul> Acesso em 10/10/13.

${ }^{368}$ MARTINS, Carlos Eduardo. O Golpe de Estado no Paraguai e a América do Sul. Carta Maior. 24/06/2012

${ }^{369}$ Art. $6^{\circ}$ : Em caso de ruptura ou ameaça de ruptura da ordem democrática em umaParte do presente Protocolo, os Presidentes das demais Partes -ou na falta destes seus Ministros das Relações Exteriores em sessão ampliada do Conselho do Mercado Comum-, poderão estabelecer, dentre outras, as medidas que se detalham a seguir: a.- Suspender o direito de participar nos diferentes órgãos da estrutura institucional do MERCOSUL. In: MERCOSUL. Protocolo de Montevidéu sobre Compromisso com a Democracia no Mercosul(Ushuaia II), Dezembro de 2011.

${ }^{370}$ ALBUQUERQUE, Del Roberto Chacón. El Mercosur y la adhesión de Venezuela. Revista De Derecho Público. $\mathrm{n}^{\circ}$ 111. Venezuela, 2007.

${ }^{371}$ Decisión Sobre La Suspensión Del ParaguayEn El Mercosur Em Aplicación Del Protocolo De Ushuaia Sobre Compromiso Democrático, Mendoza, 29 de junio 2012. Biblioteca do Senado Argentino: $\langle$ http://eventos.senado.gov.ar:88/11129.pdf> Acesso em 2 de outubro de 2013. MERCOSUR/CMC/DEC. No28/12. Regulamentación de los aspectos operativos de La Suspensión de La Republica Del Paraguay. In: MERCOSUR: 〈http://www.mercosur.int/innovaportal/file/3862/1/dec 028-2012 es reglam suspension parag uay.pdf> Acesso em 2 de outubro de 2013.

372 SECRETARIA DEL MERCOSUR. Instrumentos Fundamentales Del Mersocur. Sector de normativa, documentación y divulgación, Montevideo, Uruguai. 2012;

${ }^{373}$ FRIZZERA, Guilherme. A suspensão do Paraguai no MERCOSUL: problema interno, solução externa Conjuntura Global, Curitiba, Vol. 2, n.3, jul./set., 2013, p. 156-164.
} 
maioria absoluta, muitos congressistas levaram a discussão para a questão comercial, levando em conta que tal atitude poderia causar atritos em futuros negócios com a Argentina e o Brasil." 374

Somente em nove de dezembro de 2013, o Senado do Paraguai volta a votar e aprova a adesão da Venezuela ao Bloco. O presidente do Congresso, Julio César Velázquez, justificou sua mudança de posição: "Eu tento ser bastante prático. Sei que posso ser tratado até mesmo de antipatriótico. Sou absolutamente realista. Se insistirmos, e nós queremos reconhecer que o Brasil e a Argentina violaram o MERCOSUL, o Paraguai não vai voltar para o bloco". 375

No Brasil, historicamente, as negociações e as tomadas de decisões externas, desde a Constituição do Império de 1824 até a Constituição democrática de 1988, são atribuições consideradas inerentes ao Poder Executivo e balizadas pelo Chefe de Governo, de acordo com a ordem política vigente em cada um desses períodos da história brasileira. A atuação do parlamento brasileiro modifica-se pouco, dependendo da dinâmica diplomática e da forma de governo de cada período. A participação legal dos parlamentares nos atos internacionais evoluiu nesses períodos da seguinte forma:

a. Constituição de 1824 - no Império coube ao Poder Moderador elaborar as propostas, aprovar e assinar tratados internacionais, ficando o Poder Legislativo fora dessas deliberações ${ }^{376}$.

b. Constituição de 1891 - na Primeira República, o Legislativo passa a regular tratados comerciais e a resolver definitivamente tratados internacionais. ${ }^{377}$

\footnotetext{
${ }^{374}$ FRIZZERA, Guilherme. Op. Cit. 2013.

375 TELESUR. Senado de Paraguay aprueba ingreso de Venezuela al Mercosur. 10 de Dezembro de 2013. Disponível em: http://www.telesurtv.net/articulos/2013/12/10/senado-de-paraguay-aprueba-ingreso-devenezuela-al-mercosur-5486.html Acesso em 12/12/2013.

${ }^{376}$ Art. 102. O imperador é o Chefe do Poder Executivo, e o exercita pelos seus Ministros de Estado. São suas principais atribuições: VIII - fazer tratados de aliança ofensiva e defensiva, de subsídio e de comércio, levando-os, depois de concluídos, ao conhecimento da Assembleia-Geral, quando o interesse e a segurança do Estado o permitirem. Se os tratados concluídos em tempo de paz envolver cessão ou troca de território ou Império, ou de possessões a que o Império tenha direito, não serão ratificados sem sido aprovados pela Assembleia Geral. BRASIL. Constituição Federal Brasileira de 1824. In: REZEK, J.F. As relações Internacionais na Constituição da Primeira República. Arquivos do Ministério da Justiça. Jun. 1975. pp. 107-112.

377 A constituição de 1891, no art. 34, estabelecia ser da competência privativa do Congresso Nacional resolver definitivamente sobre os tratados e convenções com as nações estrangeiras, atribuindo ao Presidente da República, no art. 47, a competência para "entabular negociações internacionais, celebrar ajustes, convenções e tratados, sempre ad referendum do Congresso" (inciso XVI). In: FRAGA, Mirtô. O conflito entre tratado internacional e norma de direito interno: estudo analítico da situação do tratado na ordem jurídica brasileira. Rio de Janeiro: Forense, 1997. P. 62. A imposição do assentimento Legislativo para os tratados não resultou de influência de nenhum modelo constitucional estrangeiro, do qual pudessem ter sido copiados os termos empregados pela Constituição brasileira, a regra amadureceu através da própria
} 
c. Constituição de 1934/1937 - no primeiro governo Vargas, as decisões internacionais não cabiam mais ao Legislativo, pois foram centralizadas no Poder Executivo, depois O Poder Legislativo retorna a celebrar tratados, convenções e atos internacionais, ad referendum do Congresso Nacional. ${ }^{378}$

d. Constituição de 1946 - prevê a competência exclusiva do Congresso Nacional para resolver definitivamente sobre os tratados e convenções celebrados com os Estados estrangeiros pelo Presidente da República. ${ }^{379}$

e. Constituição de 1967 - ao Poder Legislativo cabe avaliar, definitivamente, tratados, acordos ou atos internacionais celebrados pelo presidente da República. ${ }^{380}$

Como se observa, não há muita variação ou diferença no tratamento constitucional do tema desde 1946. “Observa-se que, tanto na Constituição de 1967 quanto na de 1988, o poder Executivo, em comparação com os demais poderes, tem um papel eminentemente concentrado nas fases de formulação e decisão da política externa." ${ }^{381}$

A Constituição de 1988 instituiu um Estado Democrático de Direito, estruturado organicamente com os poderes semelhantes às anteriores, no que se trata do parlamento brasileiro e a incorporação de tratados. Assim, em virtude do artigo 49, cabe exclusivamente ao Legislativo:

\footnotetext{
experiência política nacional. In: CACHAPUZ DE MEDEIROS, Antônio Paulo. O poder de celebrar tratados. Competência dos poderes constituídos para a celebração de tratados, à luz do Direito Internacional, do Direito Comparado e do Direito Constitucional Brasileiro. Porto Alegre, Sergio Antonio Fabris Editor, 1995, p. 118.

378 O art. 40, da Constituição de 1937, alínea a, citava expressamente a competência exclusiva do Poder Legislativo para "resolver definitivamente sobre os tratados e convenções com as nações estrangeiras, celebrados pelo Presidente da República, inclusive os relativos à paz", reafirmando no art. 56 a competência do Presidente da República para "celebrar convenções e tratados internacionais, ad referendum do Poder Legislativo" $\left(\S 6^{\circ}\right)$. In: FRAGA, Mirtô. O conflito entre tratado internacional e norma de direito interno:estudo analítico da situação do tratado na ordem jurídica brasileira. Rio de Janeiro: Forense, 1997. P. 63.

${ }^{379}$ No art. 66, I, ser da competência exclusiva do Congresso Nacional "resolver definitivamente sobre os tratados e convenções celebrados com os Estados estrangeiros pelo Presidente da República".In: ARIOSI, Mariângela. Conflitos entre tratados internacionais e leis internas: o Judiciário e a Nova Ordem Internacional. Rio de Janeiro: Renovar, 2000. p. 140.

380 Art. 47, I, da CF-1967 In: SANCHEZ BADIN, M. R.; SILVA, E. C. G. S. ; CARDOSO, Evorah Lusci Costa; SPÉCIE, Priscila. Política Externa como política pública: uma análise pela regulamentação constitucional brasileira 1967/1988. Revista de Sociologia e Política, v. 27, p. 13-29, 2006.

${ }^{381}$ SANCHEZ BADIN, M. R.; SILVA, E. C. G. S.; CARDOSO, Evorah Lusci Costa; SPÉCIE, Priscila. Política Externa como política pública: uma análise pela regulamentação constitucional brasileira 1967/1988. Revista de Sociologia e Política, v. 27, p. 13-29, 2006.
} 
I - resolver definitivamente sobre tratados, acordos ou atos internacionais que acarretem encargos ou compromissos gravosos ao patrimônio nacional; II - autorizar o Presidente da República a declarar guerra, a celebrar a paz, a permitir que forças estrangeiras transitem pelo território nacional ou nele permaneçam temporariamente, ressalvados os casos previstos em lei complementar (...) (grifo nosso) ${ }^{382}$.

Dessa forma, a atual Constituição reafirmou o papel do Legislativo na aprovação de tratados, acordos ou atos internacionais. Essa opção determinou um caráter dualista de incorporação de legislação internacional ${ }^{383}$. Esses dois aspectos são relevantes para a compreensão das consequências da relação entre ordens legislativas extranacionais e o papel da diplomacia parlamentar. A jurisprudência do STF afirmou:

É na Constituição da República - e não na controvérsia doutrinária que antagoniza monistas e dualistas - que se deve buscar a solução normativa para a questão da incorporação dos atos internacionais ao sistema de direito positivo interno brasileiro. $\mathrm{O}$ exame da vigente Constituição Federal permite constatar que a execução dos tratados internacionais e a sua incorporação à ordem jurídica interna decorrem, no sistema adotado pelo Brasil, de um ato subjetivamente complexo, resultante da conjugação de duas vontades homogêneas: a do Congresso Nacional, que resolve, definitivamente, mediante decreto legislativo, sobre tratados, acordos ou atos internacionais (CF, art. 49, I) e a do Presidente da República, que, além de poder celebrar esses atos de direito internacional ( $\mathrm{CF}$, art. 84, VIII), também dispõe - enquanto Chefe de Estado que é - da competência para promulgálos mediante decreto. $\mathrm{O}$ iter procedimental de incorporação dos tratados internacionais - superadas as fases prévias da celebração da convenção internacional, de sua aprovação congressional e da ratificação pelo Chefe de Estado - conclui-se com a expedição, pelo Presidente da República, de decreto, de cuja edição derivam três efeitos básicos que lhe são inerentes: (a) a promulgação do tratado internacional; (b) a publicação oficial de seu texto; e (c) a executoriedade do ato internacional, que passa, então, e somente então, a vincular e a obrigar no plano do direito positivo interno ${ }^{384}$. (grifo nosso)

\footnotetext{
${ }^{382}$ BRASIL. CONSTITUIÇÃO DA REPÚBLICA FEDERATIVA DO BRASIL (1988).

${ }^{383}$ Conceito que remete ao binômio dualista/monista. O objetivo desses conceitos é diferenciar a forma como as ordens legislativas nacionais recepcionam ordens extranacionais. A teoria dualista compreende o sistema jurídico em duas ordens diferentes. Esta divisão é sustentada por dois elementos nesses sistemas jurídicos: o conteúdo e a fonte. Os sistemas jurídicos interno e internacional apresentam conteúdos e fontes diferentes, fato que os diferencia dos muitos direitos que existem, assim é possível a coexistência de duas ordens independentes e autônomas entre si porque ambas apresentam conteúdos e fontes diferentes e próprios. Ao contrário, a teoria monista sustenta a existência de uma única ordem jurídica, em que os dois ramos do direito que compõem um só sistema jurídico; tal sistema jurídico uno está baseado na identidade dos sujeitos que o compõe e na identidade das fontes. In: ARIOSI, Mariângela. Conflitos entre tratados internacionais e leis internas: o Judiciário e a Nova Ordem Internacional. Rio de Janeiro: Renovar, 2000. p. 137.

${ }^{384}$ SUPREMO TRIBUNAL FEDERAL. ADI 1480. MC, Relator: Min. CELSO DE MELLO, Tribunal Pleno, julgado em 04/09/1997, DJ 18-05-2001 PP-00429 EMENT VOL-02031-02 PP-00213.
} 
Dessa forma, o Congresso Nacional tem uma participação afirmada em atos, acordos ou tratados internacionais apenas para aprovar o acordo após a negociação. Desde um ponto de vista teórico, isso não seria um problema em si. Neoinstitucionalistas, como Helen Milner, argumentam que, em alguns Estados, a dimensão doméstica teria capacidade de afetar a política externa, fazendo com que o negociador já saiba previamente o que será ou não aprovado futuramente no Parlamento ${ }^{385}$.

Para isso, seria necessário notar a força do parlamento na aprovação dos tratados ou atos internacionais. Contudo, historicamente, não se percebe esse tratamento. Na vigência da CF de 1967, foram aprovados 148 atos internacionais, dos quais 127 multilaterais e 186 bilaterais, sendo que três foram reprovados com reserva ${ }^{386}$. De 1946 a 1981, apenas um tratado foi aprovado com emendas: o acordo de comércio e pagamento entre Brasil e Tchecoeslováquia, concluído em 1960, que foi promulgado em 1963, após o governo tcheco aceitar as emendas ${ }^{387}$.

Alguns debates são aprovados com bastante discussão. Além do caso da entrada da Venezuela, o Tratado para Proscrição de Armas Nucleares na América Latina e no Caribe (Tlatelolco) também passou por um lento processo de negociação interna. "Foi só em agosto de 1994 que o Brasil pôde ratificar após uma tramitação morosa e de difícil condução para o Itamaraty no Parlamento brasileiro." 388

\subsection{Do conceito de bem público à ordem transnacional da lex sportiva}

\footnotetext{
${ }^{385} \mathrm{O}$ argumento central entende que a cooperação entre as nações é afetada menos por medo dos ganhos relativos ou por trapaça, e mais pelas consequências domésticas distributivas de empenhos cooperativos. Assim, a questão de análise se concentra na estrutura das preferências domésticas formada pela interaçãode atores - Executivo, legislativo e grupos de interesses -, em que procedimentos são garantidos por instituições políticas e a informação tem grande papel. A informação é poder, a diferente distribuição de informação irá gerar resultados diferentes de preferências. In: MILNER, Helen. Interest, institutions and information: domestic politics and international relations. Princenton: Princeton University Press, 1997. O argumento de Milner é inspirado na teoria dos jogos de dois níveis de Robert Putnam, Ver: Diplomacy and domestic politics. The logic of two-level games, International Organization, Vol. 42, n. 3.1988.

${ }^{386}$ FRANCO, Giuliana Silva, 2008. Op. Cit.

${ }^{387}$ CACHAPUZ DE MEDEIROS, Antonio Paulo. O poder legislativo e os Tratados Internacionais. Porto Alegre: LPM, 1983, pp. 114.

${ }^{388}$ PINHEIRO, Leticia; HIRST, Monica. A política externa do Brasil em dois tempos. Revista Brasileira de Política Internacional 38.1, 1995. pp. 5-23.
} 


\subsubsection{Futebol como bem público global}

O conceito de bens públicos globais se coaduna com o transconstitucionalismo, pois é voltado a bens difusos, compartilhados entre todos, que precisam, por isso, ser regrados no marco de instituições públicas.

A hierarquia é um critério de coerência, de ligação entre todo o sistema jurídico. $\mathrm{Na}$ teoria neopositiva do Direito, todas as normas derivam de uma e mesma norma fundamental, formando um sistema de normas, uma ordem normativa, ligada à legitimação do Estado, da Constituição, hoje questionada pela globalização e pela hipercomplexidade. O critério de racionalidade do sistema normativo, já que as normas não podem ser consideradas independentemente de suas interações, é a hierarquia normativa, na qual uma norma é válida somente se uma norma superior determina a sua integração ao sistema. Esta norma fundamental é a ligação hierárquica da qual o sistema do direito é pressuposto.

A hierarquia das normas jurídicas, em que normas inferiores são legitimadas por normas superiores até chegar às normas constitucionais, elas próprias legitimadas pelo soberano democrático, faz figura de ilusão grandiosa, mascarando os paradoxos do direito ${ }^{389}$. O direito é um sistema que se apresenta como um jogo de diferenças normativas e cognitivas, como uma transformação em variação contínua de normas e de princípios inenarráveis no seu conjunto, como uma interação de atos jurídicos, cujas mudanças dependem de ambientes variáveis $^{390}$.

O processo legislativo emergente cumpre sua função de criar novas normas, mesmo que, para isso, seja necessário criar expectativas normativas de um Direito sem Estado. E o Estado é, justamente, o que dá força e validade ao Direito moderno, por isso, os novos processos legislativos internacionais não têm fundamentação no ordenamento jurídico, embora outros elementos possam integrar essa ideia de direito autônomo.

\footnotetext{
389 TEUBNER, Gunther. The King's Many Bodies: The Self-Deconctruction of Law's Hierarchy. Law and Society Review, Volume 31, Number 4, 1997, p. 763-787, p. 781.

390 A desparadoxização ocorre de muitas maneiras e é percebida historicamente. Luhmann foi ao fundo dessas questões no texto: LUHMANN, Niklas. A terceira questão - O Uso criativo dos paradoxos no Direito e na história do Direito. Tradução: Cícero Krupp da Luz; Jéferson Luiz Dutra. Estudos Jurídicos. Vol. 39 N. 1. Jan-Jun. São Leopoldo: Universidade do Vale do Rio dos Sinos, 2006. p.45-52. GuntherTeubner resume: "A chave reside na chamada desparadoxização dos paradoxos, ou seja, na aplicação criativa dos paradoxos, na transformação de uma informação infinita em finita e de uma complexidade indeterminada numa complexidade determinada" In: TEUBNER, Gunther. The King's Many Bodies: The Self-Deconctruction of Law’s Hierarchy. Law andSocietyReview, Volume 31, Number 4, 1997, p.763-787, p. 782.
} 
Assim, a hierarquia da validade jurídica passa a ser heterárquica. As fontes, as operações e as decisões não se comportam de uma maneira hierárquica, mas sim em referência ao código do direito, para uma definição de suas possibilidades operativas.

No caso em apreço, o entrelaçamento da relação da FIFA e Brasil, a ordem transnacional da lex sportiva tem como tema nuclear o esporte e, em particular, o futebol. $\mathrm{O}$ argumento que levantamos como crítica é que o futebol não é uma mercadoria material, tampouco uma propriedade intelectual. O futebol, assim como o esporte ou todos os bens culturais, não é posse de nenhum senhor, ou de qualquer organização que não seja de todos. O futebol é um bem público global. Por isso, não pode estar sujeito a regras, interesses e administração de uma entidade privada, sem legitimidade, responsabilidade ou prestação de contas pública.

O conceito de bens públicos se aproxima bastante da ideia de patrimônio comum da humanidade. $\mathrm{O}$ patrimônio comum da humanidade diz respeito à Convenção do Patrimônio Mundial da UNESCO DE $1972^{391}$, que se propõe promover a identificação, a proteção e a preservação do patrimônio cultural e natural de todo o mundo considerado valioso para a humanidade. O sentido de patrimônio mundial nela contido é o de que esse compõe um bem de interesse comum da humanidade, e não uma propriedade comum ${ }^{392}$.

Longe de ser imediatamente universais, o conceito de patrimônio comum da humanidade implica certamente num longo processo de universalização que suporia, nesta fase, que fossem reconhecidas margens nacionais no espaço e no tempo. Esta constante é necessária no início do conceito, mas também explica, talvez, a sua evolução para o bem comum da humanidade ${ }^{393}$.

Mas as noções são distintas, não devem ser confundidas, pois são complementares. Enquanto o Patrimônio da Comum Humanidade é um conceito que se relaciona com um direito de proteção a bens tangíveis e intangíveis, institucionalizado pela UNESCO, gerando política de proteção em variados níveis, o objetivo do bem público global é relacionar-se com

\footnotetext{
${ }^{391}$ A Convenção do Patrimônio Mundial, concluída em 1972, é, dentre as convenções de proteção ao patrimônio negociadas na UNESCO, a que possui maior repercussão política e econômica nos Estados-Partes e mobiliza mais recursos. (...) A proteção proporcionada pela Convenção é fundada no reconhecimento internacional do valor do patrimônio, baseado em critérios acordados pelos Estados-Partes, pela primeira vez sedimentados em um conceito de patrimônio que abrange o cultural e o natural. In: BO, João Batista Lanari. Proteção do Patrimônio da UNESCO: ações e significados. Brasília: UNESCO, 2003, p. 101.

${ }^{392}$ ZANIRATO, Sílvia Helena. Patrimônio da Humanidade: Controvérsias Conceituais e Legais. In: ENCONTRO NACIONAL DA ANPPAS, 5, 201. Anais do V ENCONTRO NACIONAL DA ANPPAS. 2010, Florianópolis.

${ }^{393}$ DELMAS-MARTY, Mireille. Etudes juridiques comparatives et internationalisation du droit. Collection: Leçons inaugurales du Collège de France. Paris: Fayard, 2003, p. 640.
} 
um aspecto mais amplo e variado de possibilidades, que implique uma crítica aos public bads e aos bens estritamente privados.

O futebol ainda não é considerado um patrimônio da humanidade no Brasil ou para a $\mathrm{UNESCO}^{394}$. Contudo, é possível sustentar que ele seja um bem público global. A ambivalência entre privado e público é reproposta nos antigos moldes da ficção jurídica criada sobre a propriedade privada: enquanto bens privados têm proprietários, tudo aquilo que não é de alguém é de todos, e, portanto, é bem público. Diferentemente do que é proposto pela FIFA, o futebol não é um bem privado, é um bem público global e, assim, não pode ser governado, administrado e legislado por uma corporação privada da mesma forma que uma rede de restaurantes ou de roupas.

Enquanto a globalização foi um processo inicialmente dirigido pelo mercado, a contraforça da governança emergiu de forma discreta e descrente, mas pode e deve ser entendida por regras, bem como por consenso e contribuição de todos os países para a regulação de public bads e a promoção de public goods ${ }^{395}$.

Os bens públicos se diferenciam de bens privados por não haver incentivo econômico à sua produção ${ }^{396}$. Entende-se que o futebol, como esporte, seja um bem público puro global.

O debate sobre bens públicos globais foi inaugurado por meio do texto produzido pelo PNUD ${ }^{397}$. A tese inicial é simples: não há como existir mercado "livre" sem regulação “estatal”. Essa tese é uma analogia aos sinais de trânsito: mesmo para se fazer compras de bens privados, é necessário ter bens públicos, como os sinais de trânsito, para organizar o

\footnotetext{
${ }^{394}$ O patrimônio cultural associa a pertinência ao conceito de "tombamento", que, no princípio, era aplicado apenas a bens materiais tangíveis, fossem eles naturais ou culturais. A ideia do tombamento de bens intangíveis é muito mais recente. No Brasil, apenas em 2004 deu-se início ao registro de bens imateriais pelo Departamento de Bens Imateriais do Instituto do Patrimônio Histórico e Artístico Nacional (IPHAN), sendo que os sete primeiros itens registrados foram a fabricação da viola-de-cocho do Mato Grosso, a produção de panelas de barro de Goiabeira-ES, o ofício das baianas de fazer acarajé, o Círio de Nazaré em Belém-PA, o jongo do Vale do Rio Paraíba, o samba de roda do Recôncavo Baiano e a pintura corporal dos índios Wajãpi no Amapá. Em nível mundial, apenas os dois últimos foram incluídos da lista das Obras-Primas do Patrimônio Oral e Intangível da Humanidade, elaborada pela UNESCO. In: PAZ, Sérgio Miranda. O Futebol como patrimônio cultural do Brasil: estudo exploratório sobre possibilidades de incentivo ao Turismo e ao Lazer. São Paulo, 2006. 245f. Tese (Doutorado) -- Escola de Comunicação e Artes da Universidade de São Paulo. Departamento de Relações Públicas, Propaganda e Turismo. Universidade de São Paulo, São Paulo, 2006.

${ }^{395}$ NAYYAR, Deepak. 'Towards Global Governance'. Governing Globalization: issues and institutions. Oxford: Oxford UP, 2002. P. 3-18.

${ }^{396}$ Para compreender a noção de public goods - bens públicos no debate internacional, utilizaremos uma abordagem analítica, que procura estabelecer critérios objetivos e ambivalentes - como puros e não puros, não-concorrentes e não-excludentes - para sua conceituação. In: KAUL, INGE, GRUMBERG, ISABELLE \& STEIN, Marc (Eds.) Defining Public Goods e Global Public Goods:concepts, policies and strategies. Global Public Goods. International Cooperation in the $21^{\text {st }}$ century. New York: Oxford University Press: 1999.

${ }^{397}$ Relatório da Reunião, organizado por IngeKaul, Isabelle Grunberget Marc A. Stern: NAÇÕES UNIDAS. Programa das Nações Unidas para o Desenvolvimento. Les biens publics à l'échelle mondiale: La coopération internationale au 21ème siècle. Nova Iorque : Oxford University Press, 1999.
} 
acesso e dar segurança até o local de compras. Simples regras de trânsito, que cuidam do bem público de todos, comprovariam, então, a necessidade do Estado e de uma legitimidade da construção dessas regras.

Para que essa formulação não pareça idealista, contrapõem-se bens públicos globais puros e impuros. Um bem público global puro é marcado por sua amplitude: ele beneficia todos os países, pessoas e gerações. O bem público global impuro, por sua vez, beneficia mais de um grupo de países, não discrimina qualquer segmento da população ou grupos de gerações $^{398}$.

Os bens públicos puros têm duas qualidades: não são concorrentes (no consumo) e não são excludentes À guisa de exemplo, a paz, o direito, a ordem ou boa administração macroeconômica são bens não-concorrentes e não-excludentes. Isso quer dizer que a utilização desses bens por um cidadão ou país não impede outros de utilizá-los também. A paz é um bem que não se esgota ou diminui por seu uso, assim como o direito, e a maioria dos bens culturais, como o futebol.

Entretanto, não se descaracteriza um bem público por não ser puramente público, pois poucos bens públicos são puramente públicos ou privados. A maioria combina tais características.

Devido à utilização da escolha racional derivada da economia, os bens públicos, por serem não-concorrentes no consumo e não-excludentes, geram os problemas típicos de free riding $^{399}$ e de dilema do prisioneiro ${ }^{400}$, de forma que os bens públicos globais estão sujeitos aos riscos da quebra do mercado e ao fracasso do governo ${ }^{401}$.

\footnotetext{
${ }^{398}$ KAUL, INGE, GRUMBERG, ISABELLE \& STEIN, Marc (Eds.). Defining Public Goods e Global Public Goods:concepts, policies and strategies. Global Public Goods. International Cooperation in the $21^{\text {st }}$ century. New York: Oxford University Press: 1999.

${ }^{399} \mathrm{O}$ conceito de free riding (ou rider) (trad. "carona") remete à possibilidade de beneficiar-se da adesão e do comprometimento dos demais atores, sem incorrer nos custos associados aos acordos. Um exemplo recorrente de problema de free-rider são as políticas globais sobre mudança climática. Nessas políticas, as democracias têm lenta passagem do papel (documentos assinados) para a prática (resultados das políticas). Isto não é uma grande surpresa, pois justamente a mudança climática é um desafio muito mais complexo do que a maioria das questões de degradação ambiental local ou regional, como a poluição do ar e da água, pois caracteriza-se essencialmente por acordo passível de free-rider global. In: Bättig, M., T. Bernauer, "National institutions and global public goods: are democracies more cooperative in climate change policy?," International Organization 63, 2, (2009): 281-308.

${ }^{400}$ O Dilema dos Prisioneiros é um dos tipos de jogos mais conhecidos. Supõe duas pessoas presas pela polícia, com algumas evidências circunstanciais, mas nada definitivo. A polícia isola cada sujeito em salas distintas e faz a seguinte proposta: se ele confessar o roubo e seu parceiro não confessar, ele será libertado em razão de sua cooperação com a polícia, enquanto o parceiro (que não confessou) será condenado a quatro anos. Se, ao contrário, ele não confessar, mas seu parceiro o fizer, ele será preso por quatro anos, enquanto seu parceiro libertado. Caso ambos confessem, a cooperação individual de um deles perde o valor como denúncia do comparsa e ambos enfrentam uma pena de dois anos de prisão. Finalmente, embora eles não saibam, se nenhum dos dois confessar, ambos serão soltos após um ano de detenção. In: FIANI, Ronaldo.
} 
O principal resultado do dilema do prisioneiro é derivado do fato de os atores não poderem se comunicar durante o jogo, estabelecendo um dilema entre cooperação versus interesse próprio. “Assim, desempenha um papel central nas teorias neoliberais de relações internacionais, uma vez que passa a representar, de forma emblemática, a anarquia como um ambiente descentralizado no qual o conflito emerge devido à situação em que os Estados interagem." ${ }^{402}$ A falta de informação sobre políticas nacionais ou o excessivo protagonismo de atores privados pode levar a piores desempenhos de bens públicos globais.

Essa noção poderia explicar o debate de convencimento entre governo e iniciativa privada para sediar um megaevento em torno de um bem público esportivo, como o futebol. Mesmo diante de altos custos de riscos políticos diversos, os estudos sobre megaeventos ex post têm frequentemente confirmado as críticas sobre o investimento público, enquanto análises ex ante rotineiramente exageram nos seus benefícios econômicos ${ }^{403}$. O efeito do freerider é outro. No nosso caso, o free-rider poderia ser atores, por exemplo, a iniciativa privada ou um grupo político, que se valeriam do megaevento futebolístico para obter vantagens econômicas ou políticas, sem ter tido custo (econômico ou político) para tanto.

Para a identificação de bens públicos globais são necessários três elementos: geográfico, socioeconômico e geracional. O bem público global precisa ser compartilhado com mais de um grupo de países, isto é, não pode ser restringido geograficamente. Nos últimos anos, as disparidades entre os Estados cresceram: os ricos ficaram mais ricos e os pobres ficaram mais pobres, pois o acesso a bens públicos, como ao conhecimento, informação, tecnologia e saúde, continua a não alcançar as populações mais pobres ${ }^{404}$. Essa

Teoria dos Jogos: com aplicações na economia, administração e ciências sociais. 3a Ed. Rio de Janeiro: Elsevier, 2009. p. 110.

${ }^{401}$ KAUL, INGE, GRUMBERG, ISABELLE \& STEIN, Marc (Eds.). Defining Public Goods e Global Public Goods:concepts, policies and strategies. Global Public Goods. International Cooperation in the $21^{\text {st }}$ century. New York: Oxford University Press: 1999.

402 MESSARI. Nizar; NOGUEIRA, João Pontes. Teoria das Relações Internacionais. Correntes e Debates. Rio de Janeiro: Elsevier, 2005. p. 93.

${ }^{403}$ Sobre "megaeventos" será detalhado a seguir no Capítulo. Os estudos ex post normalmente comparam a performance de outras regiões similares no mesmo período, mas que não sediaram o evento. Alternativamente, também são utilizadas comparações da mesma cidade ou região, antes e/ou depois do evento. Os índices utilizados são renda de pessoa física, renda per capita, emprego, variação de arrecadação de impostos, taxas de ocupação de hotéis e variação de preços, número de chegadas e partidas de aeroportos. Enquanto isso, as avaliações ex ante utilizam um número estimado de visitantes com o número esperado de dias que eles ficam no local, resultando no impacto econômico direto. Essa cifra é objeto de multiplicação, geralmente pelo fator dois, sendo chamado de impacto econômico indireto. Assim, o impacto econômico total é geralmente o dobro do valor inicial de gastos. In: MATHESON, Victor. Mega-Events: The effect of the world's biggest sporting events on local, regional, and national economies. College Of The Holy Cross, Department Of Economics Faculty Research Series, Paper06-10, 2006.

${ }^{404} \mathrm{O}$ relatório que observa todos os 30 países desenvolvidos da OCDE mostra que tem havido um aumento da desigualdade dos rendimentos, que ocorre, pelo menos, desde meados dos anos 80 e, provavelmente, desde os anos 70. Isso afetou a maioria (mas não todos) dos países, registrando-se recentemente grandes 
situação se agravou com a chegada da crise econômica financeira de $2008^{405}$. Um bem público global precisa produzir benefícios para uma grande parte da população global, não apenas para alguns.

Em longo termo, além disso, as gerações presentes devem desenvolver-se de maneira sustentável, sem comprometer as gerações futuras ${ }^{406}$. Isso é chamado de elemento geracional.

Com essa definição, os bens públicos globais podem passar a ser o conteúdo prático de uma preocupação transconstitucional e de um debate democrático que deve ocorrer no plano internacional, principalmente, dentro de um plano de legislativo representativo dos parlamentos.

O mundo político cívico pode ser associado a todos que disputam o domínio público global, entre esses as organizações de sociedade civil tanto quanto as corporações transnacionais ${ }^{407}$. O transconstitucionalismo, em qualquer dos níveis sociais, pressupõe um comprometimento democrático que se refere à condução das atividades públicas, num sentido amplo de regras, instituições e práticas. Onde tradicionalmente os Estados constituíam o espaço "público", atualmente têm lugar atores de outros níveis, levantando o debate sobre bens públicos globais, por exemplo, o meio ambiente, a paz, desenvolvimento, estabilidade econômica e, como proposto aqui, o futebol.

Assim, forçosamente, o sistema dos Estados incorpora-se a um domínio público baseado no não-estatal. O novo domínio público global precisa ser um espaço institucionalizado de discurso, contestação e ação organizada sobre a produção de bens públicos globais. Discussões institucionais dessa natureza já ocorreram no âmbito do PNUD

aumentos no Canadá e na Alemanha, por exemplo, mas diminuições no México, Grécia e Reino Unido. (...) $\mathrm{O}$ aumento moderado da desigualdade registrado ao longo das últimas duas décadas esconde uma tendência subjacente maior. Nos países desenvolvidos, os governos têm aumentado a tributação e gasto mais para desviar a tendência de maior desigualdade - gastam atualmente mais em políticas sociais do que em qualquer outro momento da história. In: OCDE. Organização para a Cooperação e Desenvolvimento Econômico. Growing Unequal?: Income Distribution and Poverty in OECD Countries. OECD Publishing, 2008.

${ }^{405} \mathrm{O}$ abismo entre pobres e ricos não cresce somente desde a crise econômica e financeira global. Segundo a Organização de Cooperação e Desenvolvimento Econômico (OCDE), no entanto, a crise econômica e financeira intensificou essa tendência, a desigualdade da renda bruta nos países da OCDE aumentou mais intensamente entre 2008 e 2010 do que nos 12 anos anteriores. In: AGÊNCIA DEUTSCHE WELLE. OCDE aponta aumento de abismo entre pobres e ricos na Europa. Carta Capital. 16/05/2013. Internacional. 2013.

${ }^{406}$ KAUL, INGE, GRUMBERG, ISABELLE \& STEIN, Marc (Eds.) Defining Public Goods e Global Public Goods:concepts, policies and strategies. Global Public Goods. International Cooperation in the $21^{\text {st }}$ century. New York: Oxford University Press: 1999

407 RUGGIE, John G. "Reconstituting the Global Domain - Issues, Actors, and Practices". European Journal of International Relations, vol. 10, n 4, December 2004, pp. 499-531. 
no debate com o Banco Mundial ${ }^{408}$. O projeto mais famoso ficou conhecido como a Taxa Tobin $^{409}$.

Persistem importantes divergências entre Estados quanto aos bens públicos globais. Assim, diante de um quadro de apoios e resistências, os bens comuns globais evoluem em paralelo à globalização. A governança global interage por um debate no qual a liberalização do mercado e os interesses privados transnacionais passam a ser sujeitos à preservação dos bens públicos globais, sejam eles abstratos, como a paz ou futebol, ou concretos, como as tributações em transações internacionais.

Esse é o caso da lex sportiva, especificamente da FIFA, em relação ao futebol. Entende-se que o futebol como atividade de desporto deve ser entendido como bem público global. Dessa forma, não poderia ser objeto da normatividade de uma organização desprovida de qualquer tipo de legitimidade ou fiscalização.

O capítulo tem o objetivo de detalhar a conjuntura de fatores que levam o Protocolo de Garantias a se tornar a Lei Geral da Copa e o debate parlamentar em torno desta. A força desse Protocolo de Garantias é tamanha que ele se torna um equivalente funcional de iniciativa legislativa. Essa será a principal ideia trabalhada e demonstrada em conjunto com a análise da forma dos atos legislativos.

\subsubsection{A ordem transnacional da lex sportiva e a FIFA}

A primeira característica de uma ordem político-jurídica transnacional é sua abrangência territorial difusa. Paradoxalmente, o território é um dos elementos definidores da competência do direito. Por isso, a ordem transnacional não tem comprometimento específico com qualquer ordem jurídica determinada, mas por um tema, por exemplo, o comércio no

\footnotetext{
${ }^{408}$ Relatório da Reunião, organizado por Inge Kaul, Isabelle Grunberget Marc A. Stern: NAÇÕES UNIDAS. Programa das Nações Unidas para o Desenvolvimento. Les biens publics à l'échelle mondiale: La coopération internationale au 21ème siècle. Nova Iorque : Oxford University Press, 1999.

409 O objetivo principal da Taxa Tobin, proposta pela primeira vez na década de 70 pelo Professor James Tobin, é reduzir a volatilidade da taxa de câmbio. Um imposto internacional uniforme pago em todas as operações à vista envolvendo a conversão de uma moeda para outra, desencorajando, em tese, a especulação por troca de moeda mais cara. In: PAHN, Paul Bernds. The Tobin Tax and Exchange Rate Stability. Finance \& Development. Junho. 1996. Trabalho original: TOBIN, James, 1978, A Proposal for International Monetary Reform, Yale University, Eastern Economic Journal pp. 153-159. Recomendação rediscutida e avaliada como positiva, em: NAÇÕES UNIDAS. Programa das Nações Unidas para o Desenvolvimento. Innovative Financing for Development: A New Model for Development Finance? Nova Iorque: January 2012. Discussão entre PNUD e Banco Mundial em: CARBONE, Maurizio. "Supporting or Resisting Global Public Goods? The Policy Dimension of a Contested Concept", Global Governance - A Review of Multilateralism and International Organization.vol. 13 n 2, 2007 pp.179-198.
} 
caso da lex mercatoria, a internet no caso da lex digitalis e o esporte, no caso da lex sportiva. Assim, a regulação de um tema global torna-se objetivo dessas ordens, pois o seu limite é o mundo, e não o Estado soberano ou o Estado de Direito.

Uma ordem político-jurídica transnacional também não trabalha na lógica de inter ou supra, pois não faz acordos com outras ordens estatais ou regionais, mas impõe-se transversalmente por um discurso regulatório. Assim, com a estruturação por atores e organizações privadas, não é possível negar-lhe o caráter de ordem jurídica com pretensão de autonomia $^{410}$.

A ordem jurídica transnacional do esporte - a lex sportiva - é objeto de uma literatura preocupada com a criação de normas e regras impostas por órgãos não estatais, na maioria das vezes associações privadas, mas com uma capacidade de coerção eficaz, por vezes, superior à coercibilidade imposta por organizações internacionais tradicionais e/ou mais legítimas ${ }^{411}$. Essa imposição jurídica diferenciada tem sido chamada de soft law ${ }^{412}$.

A lex sportiva pode ser situada por um tipo híbrido de Direito, entre o Direito Internacional do Esporte e o Direito Global do Esporte. O primeiro se refere às organizações esportivas internacionais, que têm desenvolvido um arsenal de redes de normas relativas a inscrições em campeonatos, solução de controvérsias, registros de atletas e influenciando as transferências de atletas mundialmente. O Direito Global de esportes, em contraste, pode ser definido, provisoriamente, como uma ordem legal autônoma transnacional criada por instituições privadas globais que governam esportes internacionais. Trata-se de uma ordem contratual com poder de sanção, originada por acordos que submetem os atores do esporte e

\footnotetext{
${ }^{410}$ NEVES, Marcelo. Transconstitucionalismo. São Paulo: Martins Fontes, 2009. p.165.

${ }^{411}$ NEGOCIO, Ramon Vasconcelos de. Lex Sportiva: Da autonomia Jurídica ao diálogo transconstitucional. Dissertação. PUC-SP. São Paulo, 2011.; CASINI, Lorenzo. The Making of a Lex Sportiva by the Court of Arbitration for Sport. German Law Journal 12, no. 5. 2011. pp. 1317-1340. FOSTER, Ken. Lex Sportiva and Lex Ludica: the Court of Arbitration for Sport's Jurisprudence. Entertainment and Sports Law Journal 3. Vol. 2. 2005. pp. 1-15.

${ }^{412} \mathrm{O}$ conceito de soft law pode ser entendido como um conjunto de "regras cujo valor normativo seria limitado, seja porque os instrumentos que as contêm não seriam juridicamente obrigatórios, seja porque as disposições em causa, ainda que figurando em um instrumento constringente, não criariam obrigações de direito positivo ou não criariam senão obrigações pouco constringentes. In: NASSER, Salem Hikmat. Fontes e Normas do Direito Internacional: Um estudo sobre a SOFT LAW. São Paulo: Editora Atlas, 2005. p. 25. Outro conceito: Soft law refere-se a normas internacionais que não tem caráter não vinculativo, mas ainda têm relevância jurídica, localizadas no crepúsculo entre direito e política. Exemplos importantes são aquelas emanadas de organizações internacionais e resoluções internacionais planos de ação ou códigos de conduta. In: SKJÆRSETH, Jon Birger.; STOKKE, Olav Schram; WETTESTAD, Jørgen. Soft Law, Hard Law, and Effective Implementation of International Environmental Norms. Global Environmental Politics 6:3, August 2006. p. 104.
} 
os Estados à autoridade e à jurisdição da federação internacional de esportes; não é governada por sistemas jurídicos nacionais ${ }^{413}$.

A lex sportiva é caracterizada por três elementos principais: normas internacionais geradas por regras e práticas de confederações internacionais de esportes; uma jurisprudência com princípios jurídicos que são diferentes da jurisprudência dos tribunais nacionais, emanada de suas próprias Cortes de Arbitragem do Esporte; e autonomia em relação ao Direito nacional ${ }^{414}$.

A lex sportiva engloba todas as modalidades esportivas que estejam suficientemente organizadas em nível mundial ${ }^{415}$. Assim, as normas internacionais são produzidas pelos “órgãos legislativos" das próprias organizações de cada esporte ou ramo esportivo, não passando pelo crivo governamental ou por qualquer tipo de deliberação legislativa estatal propriamente dita.

O Tribunal Arbitral do Esporte (TAE) figura como centro agregador de jurisprudência da lex sportiva, mas não como único órgão. O TAE tem capacidade de julgar e/ou mediar casos de todas as associações esportivas, uma vez que esteja previsto no Estatuto dessas associações ${ }^{416}$. Segundo o seu Estatuto: “O Tribunal Arbitral do Esporte é uma instituição independente de qualquer organização esportiva, que tem a responsabilidade de resolução de litígios relacionados com o esporte por meio de arbitragem ou a mediação, por meio de regras processuais adaptadas às necessidades específicas do mundo dos esportes." ${ }^{417}$

Algumas organizações esportivas também contam com cortes de arbitragem e mediação de $\operatorname{conflitos}^{418}$. Cada uma delas começa a acumular jurisprudência de casos particulares do seu esporte, sendo que o Tribunal Arbitral do Esporte também pode funcionar

\footnotetext{
${ }^{413}$ FOSTER, Ken. Is There a Global Sports Law? Entertainment Law, Vol. 2, No. 1, Londres: Frank Cass, Spring 2003, p.1-18. p. 2.

${ }^{414}$ FOSTER, Ken. Op. Cit. 2003.

${ }^{415}$ Levantamento de variedade de esportes (número de casos julgados) do Tribunal Arbitral do Esporte: Esqui alpino (7), Atividades Subaquáticas e de Desportos Aquáticos (1), Atletismo / Atletismo (25), Badminton (1), Baseball (2), Basquetebol (9), Biatlo (2), Bilhar (1), Bobsleigh (3), Musculação (1), Boliche (1), Boxe (5), Canoagem/Caiaque (5), Esqui cross-country/esqui (8), Curling (1), Ciclismo (37), Dança Desportiva (1), Mergulho (2), Montando Equestre / cavalo (20), Esgrima / Esgrima (1), Patinagem Artística (1), Futebol (146), Golfe (1), Ginástica (7), Handebol (2), Hóquei (6), Hóquei no Gelo (10), Judô (3), Pentatlo Moderno (1), Motociclismo / Moto (2), Competições multi-desportivas/Competições multidisciplinares (1) Desporto em patins (1), Remo (3), Vela (2), Tiro (1), Short Track (2), Skeleton (2), Snowboard (5), Patinagem de Velocidade Skating (1), Natação (30), Tênis de Mesa (2), Tênis (8), Triathlon (4), Halterofilismo (4), Luta Grega (6), Yachting (1). In: TRIBUNAL ARBITRAL DO ESPORTE (CAS). Jurisprudência. Arquivo. Disponível em: $<$ http://jurisprudence.tas-cas.org/sites/CaseLaw/ Shared\%20Documents/Forms/ PerSport.aspx > Acesso em 20/09/2013.

${ }^{416}$ Art. 1. TRIBUNAL ARBITRAL DO ESPORTE (TAE). Code2013. (Estatuto 2013). Estatuto dos organismos que trabalham para a Resolução de Disputas Esportivas. Suíça,01/03/2013.

${ }^{417}$ Art. 12. TRIBUNALARBITRAL DO ESPORTE (TAE). Op. Cit. 2013.

${ }^{418}$ Por exemplo, a FIFA conta com três cortes: Comitê Disciplinar; Comitê de Apelação, Comitê de Ética. In: Art. 61, FIFA, Op. Cit. 2013.
} 
como órgão de apelação ${ }^{419}$. Assim, não se deve limitar o campo da lex sportiva à jurisprudência do Tribunal Arbitral do Esporte, pois o fenômeno engloba regras e decisões de outras organizações esportivas transnacionais, embora ocupe posição privilegiada ${ }^{420}$.

Pode-se considerar que a lex sportiva constitua uma ordem totalmente autônoma, na medida em que reafirma, por suas organizações em rede e por jurisprudência do TAE, um distanciamento das ordens estatais. Dentre os artigos que esclarecem esse ponto, destacam-se:

Art. 37. Ao concordar em submeter qualquer assunto ao procedimento de arbitragem ordinário ou ao procedimento de arbitragem de apelação a essas regras processuais, as partes renunciam expressamente os seus direitos para solicitar tais medidas às autoridades ou tribunais estatais.

Art. 39 O painel (de julgamento do TAE) deverá decidir sobre sua própria competência, independentemente de qualquer ação legal já pendente perante qualquer tribunal estatal ou de outro tribunal arbitral referente ao mesmo objeto entre as mesmas partes, a menos que razões de mérito demandem a suspensão da processo ${ }^{421}$. (grifo nosso)

O principal pretexto jurídico utilizado pela jurisprudência do TAE para justificar a existência e funcionamento das ordens jurídicas e legislativas do esporte seria o tratamento equitativo dado a todos os atletas profissionais, em todas competições, minimizando o risco de injustiças em nível mundial, isto é, todos os jogadores do esporte $\mathrm{x}^{\prime}$ serão tratados pelo direito $x^{\prime}$. Na seguinte decisão, que diz respeito ao registro de atletas e a UEFA - União das Federações Europeias de Futebol, o TAE sustenta essa posição:

Tendo em vista as centenas de jogadores registrados para as competições da UEFA, ela não pode rever o registro de cada um. Portanto, a aceitação da lista com os jogadores registrados pelos clubes não pode ser vista como um reconhecimento de que os jogadores foram validamente registrados, mas demonstra simplesmente o reconhecimento de que o registro foi feito na forma requerida.(...) Este procedimento garante uma aplicação justa e equitativa dos regulamentos no que diz respeito ao registro de jogadores que participam das competições da UEFA, que preveem que um jogador está apto a jogar e deve ser registrado com a sua associação nacional, com base nas suas próprias disposições e as da FIFA ${ }^{422}$.

419 Art. 13. São Obrigações dos membros: a) a cumprir integralmente com os estatutos, regulamentos, diretivas e decisões dos Órgãos da FIFA, a qualquer momento, bem como das decisões do Tribunal Arbitral do Esporte (TAS) que tenham sido apelados em segunda instância com base art. 66 par. 1 do Estatuto da FIFA. Também sobre o TAS, arts. 66 e 67. In: FIFA. Op. Cit. 2013.

Estatutos;

${ }^{420}$ NEGOCIO, Ramon Vasconcelos de. Op. Cit.2011. p. 25.

${ }^{421}$ TRIBUNALARBITRAL DO ESPORTE (TAS). Code2013. (Estatuto 2013). Estatuto dos organismos que trabalham para a Resolução de Disputas Esportivas. Suíça,01/03/2013

422 COURT OF ARBITRATION FOR SPORT. (Tribunal Arbitral Do Esporte). Arbitration CAS 2011/O/2574 Union des Associations Européennes de Football (UEFA) v. FC Sion/Olympique des Alpes SA, award of 31 January 2012 (operative part of 15 December 2011). 
Tal decisão ilustra a noção de equidade esportiva. Ao decidir contra a autonomia jurídica estatal e a favor dos critérios da UEFA e das disposições da FIFA, o TAE reafirma a ideia da autonomia do direito desportivo transnacional em face das ordens estatais. O objetivo das ordens transnacionais é utilizar-se do princípio da igualdade para sustentar que seria melhor para o futebol - ou para qualquer esporte - ser regulado mundialmente por uma mesma legislação, julgamento e administração. Isto é, “determinando que o esporte em nível internacional não poderia obedecer a uma multiplicidade de regras nacionais potencialmente contraditórias". ${ }^{423}$ Nesse sentido, a mesma decisão reafirma:

\begin{abstract}
Nas suas alegações, a UEFA e as terceiras partes insistiram no fato de que para as competições internacionais como UEL (Liga Europeia) 2011/2012, que inclui a participação de mais de 50 países, o princípio da igualdade entre os participantes deve ser preservado. Se as únicas autoridades competentes para verificar o registro de jogadores fossem as federações nacionais, não seria possível alcançar a igualdade ${ }^{424}$.
\end{abstract}

Sob um olhar transconstitucional, um dos princípios que ocupam o lugar de pontes de transição é o princípio da igualdade, ligando uma ordem estatal e uma ordem esportiva transnacional: "ela tende a submeter todos os atletas a um tratamento igualitário." 425 A concepção de haver um tratamento igualitário para atletas, do ponto de vista constitucional, não parece problemática. O que parece discutível é a falta de democracia e participação dentro dessas organizações com controle absoluto sobre a matéria. Este monopólio sem qualquer tipo de fiscalização democrática pode evidenciar uma série de arbitrariedades ${ }^{426}$. Isso ocorre em muitas organizações desse nível, mas destacamos, para o caso, a FIFA.

A FIFA - Federação Internacional de Futebol (Fédération Internationale de Football Association) é uma associação, alocada em Zurique, na Suíça, fundada em1904 e que conta com mais de 200 associações nacionais ${ }^{427}$. É o órgão mundial que administra o esporte de

\footnotetext{
${ }^{423}$ NEVES, Marcelo. Op. Cit. p. 175.

424 COURT OF ARBITRATION FOR SPORT. (Tribunal Arbitral Do Esporte). Arbitration CAS 2011/O/2574 Union des Associations Européennes de Football (UEFA) v. FC Sion/Olympique des AlpesSA, award of 31 January 2012 (operative part of 15 December 2011).

425 NEVES, Marcelo. Op. Cit. p.177.

${ }^{426}$ A literatura de Relações Internacionais normalmente estuda este conceito em associação com a accountability. Accountability, por sua vez, "implica que alguns atores tenham o direito de manter outros atores num quadro de regras, para julgar se eles cumpriram suas responsabilidades ou impor-lhe sanções caso contrário.” In: KEOHANE, Robert; GRANT, Ruth. Accountability and Abuses of Power in World Politics. The American Political Science Review, vol. 99, n 1, February 2005, pp. 29-43.

${ }^{427}$ Art. $1^{\circ}$. FIFA.: registrada na Junta Comercial de acordo com o art. 60 do Código Civil Suíço Op. Cit. 2013. Art. 60 do Código Civil Suíço - Associações que tiverem objetivo político, religioso, científico, artístico, de caridade, social, ou qualquer outro além do industrial, adquirem o status de pessoa assim que
} 
Futebol Associado por programas e pela organização, supervisão e promoção de competições internacionais de Associação de Futebol ${ }^{428}$.

O seu poder é absoluto e total, pois engloba três níveis - legislativo, jurídico e executivo - por meio de seus órgãos: o Congresso, órgão supremo e legislativo; o Comitê Executivo e a Secretaria Geral, órgãos administrativos e executivos; o Comitê de Ética, o Comitê Disciplinar e o Comitê de Apelação são os órgãos judiciários da $\mathrm{FIFA}^{429}$. O Congresso é considerado pelo Estatuto como “o órgão supremo e legislativo." ${ }^{430}$ Esse Congresso é formado pela congregação de associações nacionais, cada um com direito a um voto, e deve reunir-se anualmente, tendo o poder exclusivo de alterar estatuto, os regulamentos que regem a aplicação dos estatutos e os regulamentos do Congresso da FIFA $^{431}$.

Com essa estrutura, a FIFA vem desempenhando um poder de império sobre o futebol. Surpreendentemente, a princípio, não haveria na estrutura hierárquica qualquer razão jurídica para que uma "norma", ou melhor, uma regulação da FIFA prevalecesse sobre as normas nacionais de qualquer país. Mas a relação heterárquica, em rede e em cascata, impede as Associações, os clubes e os cidadãos de recorrerem às jurisdições nacionais para resolverem qualquer conflito relativo às suas normas e decisões, sob um rigoroso Código Disciplinar escrito e aprovado pelo Congresso da FIFA -, julgado pelo Comitê Disciplinar - órgão da FIFA - e executado pelo Comitê Executivo da FIFA, por confederações regionais e por associações com uma eficácia ímpar frente aos sistemas jurídicos internacionais.

Dessa forma, sendo a um só tempo legisladora, juíza e administradora, a FIFA se materializa como um monopólio supremo na sua administração do futebol no plano global, com intervenção ativa nas associações nacionais, confederações regionais, clubes e atletas.

Essa intervenção é fundada no efeito heterárquico de suas punições e na regra última de desobediência: a punição de ser excluído das competições FIFA, eventos das suas associações nacionais e privilégios agregados. A FIFA constitui, assim, a formação de uma

\footnotetext{
mostrarem através das suas constituições suas intenções de existirem como corporação. A constituição deve ser redigida por escrito e deve determinar o propósito, o capital e a organização da sociedade. In: FIFA. Op. Cit. 2013.; TOMLINSON, Alan; YOUNG Christopher. Culture, Politics, and Spectacle in the Global Sports Event - An Introduction. National Identity and Global Sports Events: Culture, Politics and Spectacle in the Olympics and the Football World Cup. Albany: State University of New York Press, 2006.

${ }^{428}$ FIFA. Bidding Agreement. Regarding the Submission of bids for the right to host and stage the 2018 FIFA WORLD CUP or 2022 FIFA WORLD CUP. Zurich, Suíça. p. 37.

${ }^{429}$ Art. 21; ART. 61. In: FIFA. Op. Cit. 2013.

${ }^{430}$ Art. 21, n.1.In: FIFA. Federação Internacional do Futebol. Estatuto da FIFA. Edição: Julho de 2013.

${ }^{431}$ Art. 23, 22 e 26. n. 1. In: FIFA. Op. Cit. 2013.
} 
rede de poder que tem força desde a Copa do Mundo até as séries menos profissionalizadas de futebol, em toda parte do planeta ${ }^{432}$.

Um dos princípios capitais de sustentação desse sistema é a exclusão do Estado. É defeso a cidadãos, clubes, organizações ou mesmo às federações filiadas entrarem em litígio em qualquer órgão administrativo ou jurisdicional que não seja próprio da FIFA, ou previsto em seu estatuto, principalmente de órgãos estatais. Para assegurar esse monopólio, a FIFA prevê medidas disciplinares a associações, clubes e indivíduos, as quais se estendem desde a multa até a proibição absoluta de exercer qualquer atividade relacionada ao futebol associado, caso suas decisões, regulamentos ou sentenças, por exemplo, não sejam rigorosamente $\operatorname{seguidos}^{433}$.

Essas restrições são determinadas no Estatuto da FIFA, no Código Disciplinar da FIFA e no Código de Ética da FIFA ${ }^{434}$. Da mesma forma que a lex sportiva e o Tribunal Arbitral do Esporte, o Estatuto da FIFA inclui artigos que têm o objetivo de garantir o cumprimento e um maior controle do seu próprio sistema, afastando não apenas o monopólio do Estado das decisões que concernem ao Esporte, mas a sua competência:

Art. 68, n.2. Recorrer aos tribunais de justiça estatais é proibido a menos que especificamente citado pelos nos regulamentos da FIFA. O recurso aos tribunais de direito comum para todos os tipos de medidas cautelares também é proibido.

Art. 68, n.3. As Associações devem inserir uma cláusula nos seus estatutos ou regulamentos estipulando que é proibido levar disputas da Associação ou disputas afetando campeonatos, membros de campeonatos, clubes, membros de clubes, jogadores, oficiais e outros funcionários aos tribunais de justiça estatais, a menos que os Regulamentos da FIFA ou disposições legais especificamente prevejam ou estipulem recursos aos tribunais de justiça estatais. Em vez de recorrer aos tribunais de justiça estatais, serão tomadas disposições para a arbitragem. Tais disputas devem ser levadas a um tribunal arbitral independente e devidamente constituído reconhecida pelas regras da Associação, Confederação ou a TAE ${ }^{435}$.

A passagem destacada - "as Associações devem inserir uma cláusula nos seus estatutos ou regulamentos estipulando que é proibido levar disputas (...) aos tribunais de

\footnotetext{
${ }^{432}$ As punições incluem, de acordo com art. 65: a) a proibição de transferência; b) jogar uma partida sem espectadores; c) jogando uma partida em território neutro; d) proibição de jogar em um estádio particular; e) a anulação do resultado de um jogo; f) expulsão; g) multa; h) dedução de pontos; i) o rebaixamento para a divisão inferior; j) repetir um jogo.

${ }_{433}$ Art. 28, FIFA. Federação Internacional do Futebol. Disciplinary Code. Edição 2011.

${ }^{434}$ FIFA. Federação Internacional do Futebol. Estatuto da FIFA. Edição: Julho de 2013; FIFA. Federação Internacional do Futebol. Disciplinary Code. Edição 2011; FIFA. Federação Internacional do Futebol. FIFA Code of Ethics.Edição 2012.

${ }^{435}$ FIFA. Op. Cit. 2013.
} 
justiça estatais" - torna o sistema da lex sportiva do futebol capaz de ser autônomo, pois cria uma estrutura muito parecida com a estrutura jurídica habitual justamente ao proibir todos os seus membros nacionais de acionarem a justiça comum. A FIFA torna-se absoluta e suprema no que se refere ao futebol, com mais poder que qualquer Estado na matéria.

Destarte, a construção de uma ordem transnacional autônoma, como a lex sportiva do futebol, sustenta-se pela sutileza da coerção da soft law, imposta aos membros associados:

As associações devem também assegurar que essa estipulação seja implementada na Associação, se necessário através da imposição de uma obrigação vinculativa para os seus membros. As Associações aplicarão sanções a qualquer membro que não respeitar esta obrigação e garantir que qualquer recurso de tais sanções devem ser igualmente estritamente submetida à arbitragem, e não aos tribunais ordinários da $1 \mathrm{li}^{436}$.

Dentre as sanções previstas, destaca-se o banimento da participação de competições FIFA, regional (Europeia, Sul-americana, Africana, etc.) e nacional do associado ${ }^{437}$. Assim, todos os clubes, jogadores e associações que tiverem o objetivo de participar dos eventos FIFA precisam abrir mão da jurisdição estatal. A força dessa estrutura jurídica é tão grande que vincula até os próprios torcedores. Embora eles não estejam vinculados "voluntariamente" por um estatuto jurídico da FIFA ou de uma associação, o seu clube ou o seu interesse poderão ser prejudicados pela sua iniciativa pessoal.

Foi o que aconteceu no Brasil, em 2005, quando o advogado e torcedor do Sport Club Internacional - Internacional, Leandro Konrad Konflanz, moveu ação na Justiça comum contra a CBF e o STJD (Superior Tribunal de Justiça Desportiva) ${ }^{438}$. Ele solicitava a reversão da anulação dos onze jogos apitados por Edilson Pereira de Carvalho no Campeonato Brasileiro, o que faria com que o Internacional se tornasse Campeão Brasileiro daquele ano $^{439}$.

Contudo, após a Conmebol (Confederação Sul-Americana de Futebol) enviar um ofício à CBF ameaçando formalmente a vaga na Taça Libertadores da América ao Internacional caso a ação na Justiça comum fosse mantida, o torcedor retirou de imediato a ação, conforme seu depoimento: "O que me levou a ajuizar esta ação foi o sentimento de paixão, de amor ao Inter. E agora não teria razão alguma continuar com o processo se o

\footnotetext{
${ }^{436}$ FIFA.Op. Cit. 2013.

${ }^{437}$ Art. 28, FIFA. Federação Internacional do Futebol. Disciplinary Code. Edição 2011.

${ }^{438}$ TRIBUNAL DE JUSTIÇA DO RIO GRANDE DO SUL. $1^{\text {a }}$ Vara Cível do Foro Central Processo Número: 001/1.05.2429826-6. Arquivado - Caixa 8396. 01/12/2007.

${ }^{439}$ FOLHA DE SÃO PAULO. Após ameaça, torcedor do Inter retira a ação contra a CBF. Folha Online. Esporte. 09/12/2005. Disponível em: 〈http://www1.folha.uol.com.br/folha/esporte/ult92u96309.shtml> Acesso em 20/12/2012.
} 
próprio presidente do Inter me fez um apelo solicitando que eu retirasse a ação pelo bem do clube" ${ }^{, 440}$.

Dessa forma, comprova-se que o sistema da lex sportiva da FIFA funciona. Não apenas associações, mas clubes e torcedores, estão vinculados a essa ordem transnacional do futebol. Dessa forma, além do controle efetuado por seus próprios órgãos, há um controle de soft laws em que a pena a um membro dissidente é a exclusão na participação dos prestigiosos eventos FIFA e de suas competições, que envolvem, mais do que da excelência dos melhores jogadores, muitos incentivos econômicos ${ }^{441}$.

Além do déficit democrático, a organização também tem sido acusada de corrupção e criticada por observadores e atores por sua falta de transparência e prestação de $\operatorname{contas}^{442}$.

\begin{abstract}
Depois de assegurar os votos de que necessitava para garantir sua sobrevivência no poder, Blatter tinha de pagar outra dívida. Havelange tivera um papel decisivo na eleição de Blatter em 1998; agora era hora de retribuir. Ricardo Teixeira merecia ganhar sua própria Copa do Mundo, para desse modo poder cuidar dos "arranjos" financeiros e escrever os contratos. Isso ficou acertado para 2014. (...) E, assim, chegou ao fim o "sistema de revezamento" entre continentes. Os velhos gananciosos da FIFA queriam a volta de uma concorrência global para sediar a Copa com sua enxurrada de propinas. E foi então que um deles teve uma ideia brilhante! O que podia ser melhor que uma tonelada de propinas? Resposta: duas toneladas de propinas!
\end{abstract}

Depois de uma série de escândalos, em 2011, a FIFA iniciou um processo de reforma da governança, nos moldes do Comitê Olímpico Internacional ${ }^{443}$. Entretanto, a FIFA continua a ter muito prestígio no mundo do futebol e dentre as estruturas políticas e governamentais. Esses interesses parecem alinhar-se quando são apresentadas as propostas de megaeventos para os governos nacionais.

\footnotetext{
${ }^{440}$ FOLHA DE SÃO PAULO. Op. Cit. 2005.

${ }^{441}$ De acordo com a Revista Forbes, a título de exemplo, quatro dos dez dos eventos esportivos mais bem pagos do mundo estão relacionados com o Futebol. Dois deles são da FIFA, a Copa do Mundo e o Torneio de Clubes Mundial. In: FORBES. Sports Money.The Ten Highest-Paying Sporting Events In The World.6/5/13. Disponível em: <http://www.forbes.com/sites/monteburke/2013/06/05/the-ten-highest-payingsporting-events-in-the-world/> Acesso em 10/10/13.

${ }^{442}$ Denúncias, depoimentos sobre a corrupção sobre Copas e FIFA, ver: JENNINGS, Andrew. Jogo Sujo: o mundo secreto da FIFA: compra de votos e escândalo de ingressos. Tradução Renato Marques de Oliveira. São Paulo: Panda Books, 2011. p.312.

${ }_{443}$ PIELKE, R., How can FIFA be held accountable?.Sport Management Review (2013), http:// dx.doi.org/10.1016/j.smr.2012.12.007
} 
Embora o poder da FIFA sobre regras, condutas e disciplinas seja contundente e inquestionável, sua grande fonte de renda são os megaeventos mundiais organizados periodicamente, destacando-se, dentre eles, a Copa do Mundo ${ }^{444}$.

Países ou cidades organizaram-se em verdadeiras competições estatais, medindo forças e capacidades de investimento, maturidade institucional, segurança, em síntese: ter um megaevento como uma Copa do Mundo, Jogos Olímpicos ou eventos do gênero tornou-se medida de reputação. "Megaeventos esportivos tornaram-se parte integrante das estratégias empresariais das cidades que buscam ganhar vantagem competitiva na economia global." ${ }^{445}$

$\mathrm{O}$ incremento ao turismo a curto e médio prazo transformou-se em um dos principais argumentos favoráveis e supostamente indiscutíveis para atrair candidatos a megaeventos. Para tanto, os governos realizam uma significativa ginástica administrativa para se submeterem às exigências das instituições organizadoras, que incluem desde isenções fiscais a mudanças na legislação nacional, configurando o que alguns membros da diplomacia parlamentar brasileira têm denunciado, nas discussões em torno da Copa do Mundo 2014, como "Estado de Exceção da FIFA". ${ }^{446}$

Megaeventos tornaram-se também um componente importante de promoção local e nacional. Eles teriam capacidade de dar novos horizontes de reputação internacional aos países, deixando para trás heranças sociais, econômicas e físicas desagradáveis, como os Jogos Olímpicos de 2008, na China, e a Copa do Mundo da África do Sul, em 2010. ${ }^{447}$

Em tese, esses eventos teriam um impacto sobre a comunidade local por um período muito maior do que aquele em que ocorreu o evento ${ }^{448}$. Não há, porém, fórmulas conclusivas sobre o impacto deles nos diferentes tipos de população. Enquanto os impactos do desenvolvimento de megaeventos em países em desenvolvimento são frequentemente elogiados, "há pouca garantia dos reais efeitos na redução da pobreza, ao mesmo tempo que

\footnotetext{
${ }^{444}$ Segundo o Relatório Contábil da FIFA 2012, os direitos televisivos, de marketing e de licenciamento de produtos para a Copa do Mundo Brasil 2014 foram vendidos por USD 1,018 Bilhão, quase 90\% do total do faturamento da FIFA para 2012. In: FIFA. FINANCIAL REPORT.63rd Congress. Muritius, Maio de 2013.p. 16.

${ }^{445}$ HALL, C.M. Op. Cit. 2006. P. 67.

${ }^{446}$ O projeto da Lei Geral da Copa - bem mais do que uma "lei do copo de cerveja" - nas partidas transforma o Brasil em protetorado de interesses mercantis. Ele "expulsa de campo" a legislação nacional que regula concorrência, patentes, direitos do consumidor, transmissões esportivas, gastos orçamentários, publicidade, punição a delitos e até calendário escolar. A lei das licitações já fora "escanteada" pelo Regime Diferenciado de Contratações. Uma entidade privada internacional impõe legislação excepcional, garantindo isenções fiscais a mais de mil produtos! O "Estado Futebolístico de Exceção" cria suas "zonas de exclusão". In: ALENCAR, Chico. Estado Futebolístico de Exceção. A Folha de São Paulo. São Paulo, 15/04/12. Opinião.

${ }^{447}$ Esta associação também poderia incluir os regimes militares da América do Sul e a Copa da Argentina em 1978, o regime nazista e os Jogos Olímpicos de 1936 na Alemanha, entre outros.

${ }^{448}$ HALL, Michael C. Urban entrepreneurship, corporate interests and sports mega-events: the thin policies of competitiveness within the hard outcomes of neoliberalism. The Editorial Board of the Sociological Review. Published by Blackwell Publishing Ltd. 2006. EUA. P.2
} 
se corre um risco de inflar seus legados numa panaceia para os desafios de desenvolvimento do país." 449

Nesse caso, os grandes legados podem se transformar em grandes problemas. Nos Jogos Olímpicos de Montreal, em 1976, o governo local construiu diversas novas instalações, incluindo o grandioso Estádio Olímpico, e acabou com dívidas que totalizaram \$ 1,2 bilhão de dólares. Estas dívidas foram pagas por trinta anos após os Jogos ${ }^{450}$.

Os primeiros estudos sobre megaeventos foram iniciados na década de 1970 e focaram em turismo e seus efeitos sobre a duração de seu impacto a médio prazo. Na década de 1980, os estudos incluíram avaliação de seu tamanho ou escala ${ }^{451}$. A atual literatura sobre megaeventos e nações em desenvolvimento tem se centrado em questões de desenvolvimento e redução de pobreza ${ }^{452}$, promoção local, benefícios das candidaturas a megaeventos ${ }^{453}$, construção de identidade urbana e impacto nas cidades ${ }^{454}$.

Esses estudos acompanham a mudança na importância relativa dos megaeventos relacionada com a globalização dos meios de comunicação, juntamente com a facilitação dos meios de transportes, tendo impacto comercial em eventos esportivos ${ }^{455}$. No caso da Copa do Mundo de Futebol de 2006, na Alemanha, apesar de aproximadamente três milhões de bilhetes terem sido emitidos para os 64 jogos, a audiência televisiva mundial foi estimada em meio bilhão de pessoas por jogo ${ }^{456}$.

Atualmente, Megaeventos têm sido definidos como "eventos únicos ou recorrentes de duração limitada, desenvolvidos principalmente para aumentar a consciência, o apelo e rentabilidade de um destino turístico em um curto e/ou longo prazo". ${ }^{457}$ Os megaeventos esportivos trariam ao menos três benefícios: infraestrutura, desenvolvimento e reputação.

${ }^{449}$ PILLAY, Udesh; BASS, Orli.Mega-events as a Response to Poverty Reduction: the 2010 FIFA World Cup and its Urban Development Implications. Urban Forum 19:329-346. 2008.

${ }^{450}$ MATHESON, Victor. Mega-Events: The effect of the world's biggest sporting events on local, regional, and national economies. College Of The Holy Cross, Department Of Economics Faculty Research Series, Paper 06-10, 2006. p. 19.

451 DIAEY, Taha; DUFOURG, Jérôme; J. TJUŠEVS, Pāvels; GARAVELLI, Alberto Zamboni. Bidding: How can you win even if you lose? Identifying the legacies of lost bids to host a sports mega event. CIES. Disponível em http://doc.rero.ch/record/24858/files/2011_Bidding_how_can_we_win_if_we_lose.pdfAcesso em 11/11/10. p. 6

${ }_{452}$ PILLAY, Udesh; BASS, Orli. Mega-events as a Response to Poverty Reduction: the 2010 FIFA World Cup and its Urban Development Implications. Urban Forum 19:329-346. 2008.

${ }^{453}$ DIAEY, Taha; et al Op. Cit.

${ }^{454}$ ERTEN, S. Spatial analysis of mega-event hosting: Olympic host and Olympic bid cities, Tese de Doutorado. Middle East Technical University, 2008.

${ }^{455}$ HALL, Michael C. Urban entrepreneurship, corporate interests and sports mega-events: the thin policies of competitiveness within the hard outcomes of neoliberalism. The Editorial Board of the Sociological Review. Published by Blackwell Publishing Ltd. 2006.EUA.P.4.

${ }^{456}$ STARCK, P. Soccer World Cup to boost German 2006 GDP - Study, The Guardian, 01/12/2005.

${ }^{457}$ RITCHIE, B., Assessing the Impact of Hallmark Event: Conceptual and Research Issues, Journal of Travel Research, Vol. 23, 1984. 
Primeiro, a infraestrutura necessária para tais eventos é geralmente considerada como parte integrante do desenvolvimento econômico do Estado que os sedia. Em segundo lugar, a acolhida de eventos é vista como uma contribuição para a vitalidade dos negócios e para o desenvolvimento econômico. Em terceiro lugar, a capacidade de atrair eventos é muitas vezes considerada um indicador de desempenho da capacidade de uma cidade ou região para competir internacionalmente ${ }^{458}$.

As ligas, donos de equipes e os organizadores do evento têm um incentivo forte para fornecer números de impacto econômico excessivamente positivo, a fim de justificar a realização do evento, e os consequentes subsídios públicos e privados. Por exemplo, de uma perspectiva dos esportes e megaeventos dos Estados Unidos da América: a National Football League (NFL) afirma que o impacto econômico do Super Bowl varia de cerca de US \$ 300 a \$ 400 milhões; a Major League Baseball (MLB) atribui um benefício de US \$ 75 milhões para o All-Star Game, e até quase 250 milhões de dólares para o World Series; e para o National Collegiate Athletic Association (NCAA) de basquete masculino, o Final Four varia entre R \$ 30-110 milhões ${ }^{459}$.

Entretanto, muitas vezes, essas estimativas são amplamente otimistas sobre o número de visitantes em potencial e seus futuros gastos, e, em consequência, sobre seus efeitos positivos. Por exemplo, observa-se uma notável diferença nos estudos dedicados ao impacto econômico ex ante (estudos prévios e avalizadores do megaevento) em comparação com aqueles que se ocupam do impacto ex post (estudos independentes e posteriores ao megaevento), e essa diferença na metodologia e dados utilizados implica diferenças também nos resultados. As análises ex post geralmente confirmam as críticas do impacto econômico discutidas, demonstrando que os estudos ex ante rotineiramente exageram nos benefícios dos megaeventos ${ }^{460}$.

Com efeito, os estudos ex ante em geral exageram quanto ao número de pessoas que eles atraem e seus gastos. Os oficiais de Denver, cidade do interior dos Estados Unidos da América, previam 100.000 visitantes para o All-Star Game da NBA, Associação Nacional de Basquete estadunidense. Contudo, considerando que o Pepsi Center, local do jogo, tinha

\footnotetext{
${ }^{458}$ HALL, Michael C. Urban entrepreneurship, corporate interests and sports mega-events: the thin policies of competitiveness within the hard outcomes of neoliberalism. The Editorial Board of the Sociological Review. Published by Blackwell Publishing Ltd. 2006. EUA.

${ }^{459}$ MATHESON, Victor. Mega-Events: The effect of the world's biggest sporting events on local, regional, and national economies. College Of The Holy Cross, Department Of Economics Faculty Research Series, Paper 06-10, 2006. P. 3

${ }^{460}$ MATHESON, Victor. Mega-Events: The effect of the world's biggest sporting events on local, regional, and national economies. College Of The Holy Cross, Department Of Economics Faculty Research Series, Paper 06-10, 2006.
} 
capacidade para 20.000 espectadores e que a malha hoteleira de Denver tem 6.000 leitos, a estimativa torna-se incompreensível, sendo bem provável que o número tenha sido muito menor $^{461}$.

Politicamente, os megaeventos podem servir de formas diametralmente opostas. Em 1995, a Copa do Mundo de Rúgbi na África do Sul representou uma oportunidade para o país anunciar que estava se reerguendo não apenas como um membro do mundo esportivo, mas como membro da comunidade política internacional ${ }^{462}$. Ao contrário, em outros casos, os megaeventos podem servir para o fortalecimento de regimes autoritários. Os XVI Jogos da Commonwealth de 1998 foram realizados na Malásia. O governo local, por meio de uma organização estratégica, conseguiu fazer com que os Jogos da Commonwealth fossem muito mais atraentes do que o normal, minimizando a crise política ${ }^{463}$.

A literatura engloba três categorias de consenso sobre benefícios exagerados de megaeventos ${ }^{464}$. O primeiro relaciona-se com o aumento do faturamento bruto, e não o líquido, que os jogos trariam, não incluindo no cálculo os gastos habituais da população. Segundo, o número de turistas numa região, pois, ao mesmo tempo que pessoas irão aos jogos, muitas outras (turistas regulares e locais) evitarão essas regiões durante as competições. E, por último, a noção de efeito multiplicador de um investimento (sobre o qual um gasto gerará outros em efeito escala) é menor quando realizado num megaevento do que se fosse gasto em bens ou serviços locais ${ }^{465}$.

O faturamento deve ser analisado tomando em consideração o investimento público e retorno em benefícios e empregos. A Copa do Mundo de 1994, nos Estados Unidos da América, revelou que, ao contrário da expectativa de ganhos de $\$ 4$ bilhões de dólares, as

\footnotetext{
${ }^{461}$ MATHESON, Victor. Mega-Events: The effect of the world's biggest sporting events on local, regional, and national economies. College Of The Holy Cross, Department Of Economics Faculty Research Series, Paper 06-10, 2006. p. 4

${ }_{462}$ MATHESON, Victor. Mega-Events: The effect of the world's biggest sporting events on local, regional, and national economies. College Of The Holy Cross, Department Of Economics Faculty Research Series, Paper 06-10, 2006. p. 6.

${ }^{463}$ VAN DER WESTHUIZEN, J. Marketing Malaysia as a model modern Muslim state: the significance of the 16th Commonwealth Games. Third World Quarterly, 25(7), 2004. pp. 1277-1291.

${ }^{464}$ Ver: ERTEN, S. Spatial analysis of mega-event hosting: Olympic host and Olympic bid cities, Tese de Doutorado. Middle East Technical University, 2008. ; HALL, Michael C. Urban entrepreneurship, corporate interests and sports mega-events: the thin policies of competitiveness within the hard outcomes of neoliberalism. The Editorial Board of the Sociological Review. Published by Blackwell Publishing Ltd. 2006. EUA. ; MATHESON, Victor. Mega-Events: The effect of the world's biggest sporting events on local, regional, and national economies. College Of The Holy Cross, Department Of Economics Faculty Research Series, Paper 06-10, 2006.; PILLAY, Udesh; BASS, Orli. Mega-events as a Response to Poverty Reduction: the 2010 FIFA World Cup and its Urban Development Implications. Urban Forum 19:329-346. 2008.; DIAEY, Taha; DUFOURG, Jérôme; J. TJUŠEVS, Pāvels; GARAVELLI, Alberto Zamboni. Bidding: How can you win even if you lose? Identifying the legacies of lost bids to host a sports mega event.

${ }^{465}$ PILLAY, Udesh; BASS, Orli. Mega-events as a Response to Poverty Reduction: the 2010 FIFA World Cup and its Urban Development Implications. Urban Forum 19:329-346. 2008. p. 335
} 
cidades-sedes tiveram perdas entre $\$ 5.5$ - 9.3 bilhões ${ }^{466}$. Os padrões de segurança e exigências do Comitê Olímpico Internacional, pagos com dinheiro público, custaram aos cofres gregos \$1,5 bilhão de dólares para os Jogos Olímpicos de 2004, em Atenas ${ }^{467}$. A África do Sul tinha expectativa de criar 150 mil empregos, mas na realidade foram gerados empregos num plano de baixo e médio nível de escolaridade para a construção de estádios e infraestrutura para a Copa de 2010, que têm a tendência de serem empregos temporários e envolverem números finitos ${ }^{468}$. A análise das Copas do Mundo realizadas na França, em 1998, e na Alemanha, em 2006, também demonstrou que dificilmente as Copas do Mundo e outros megaeventos têm impactos positivos a curto prazo sobre o turismo, emprego e renda $^{469}$.

Não há estudos conclusivos de que se consiga transformar uma cidade em destino turístico permanente com um megaevento ou de que esses eventos resultem em aumentos significativos ${ }^{470}$. Por exemplo, no caso da Copa do Mundo da Coreia do Sul/Japão, em 2002, o número de visitantes ao país foi maior que o habitual, mas ao mesmo tempo surtou um efeito rebote:o número de turistas regulares e de viajantes de negócios diminuíram. Assim, “o número de visitantes total para a Coreia do Sul durante a Copa de 2002 foi estimado em 460.000, um número idêntico à cifra de visitantes estrangeiros durante o mesmo período do ano anterior." 471

O efeito multiplicador é limitado pelo inúmero de empresas transnacionais que investem nas organizações que administram o evento no intuito de obterem vantagens exclusivas. Esses interesses corporativos dos megaeventos dominam o agendamento de eventos, seu desenvolvimento, planejamento e regulação. Por causa do desejo de exclusividade para seus produtos, na Copa do Mundo de 2006, na Alemanha, as licenças oficiais das multinacionais patrocinadoras do evento baniram a salsicha e a cerveja alemã dos estádios. Nos estádios, a exclusividade era da cerveja Anheuser Busch e dos lanches do

\footnotetext{
${ }^{466}$ MATHESON, Victor. Mega-Events: The effect of the world's biggest sporting events on local, regional, and national economies. College Of The Holy Cross, Department Of Economics Faculty Research Series, Paper 06-10 (2006).

${ }_{467}^{46}$ MATHESON, Victor. 2006 Op. Cit.

${ }^{468}$ PILLAY, Udesh; BASS, Orli. Mega-events as a Response to Poverty Reduction: the 2010 FIFA World Cup and its Urban Development Implications. Urban Forum 19:329-346. 2008.

${ }^{469}$ ALLMERS, Swantje; MAENNIG, Wolfgang. Economic impacts of the FIFA Soccer World Cups in France 1998, Germany 2006, and outlook for South Africa 2010. Eastern Economic Journal, 35, (500519), 2009.

${ }^{470}$ MATHESON, Victor. 2006 Op. Cit. Todos estudos são inconclusivos e não são capazes de revelar a conexão entre megaeventos e futuro destino turístico.

${ }^{471}$ MATHESON, Victor. 2006 Op. Cit. p. 10.
} 
McDonalds ${ }^{472}$. Certamente, os empresários que apoiaram a candidatura alemã à Copa e o investimento público despendido para a Copa do Mundo ficaram surpresos e decepcionados. A Alemanha gastou $\$ 1,4$ bilhão de euros construindo e reformando 12 estádios para a Copa do Mundo de 2006, dos quais no mínimo 35\% foram pagos com dinheiro público do município, estados e governo federal ${ }^{473}$.

Portanto, não é surpreendente que haja uma forte ligação entre o capital transnacional e eventos esportivos globais que fornecem uma base para a criação de parcerias entre os interesses transnacionais e o local ${ }^{474}$.

\begin{abstract}
Enquanto os patrocinadores de eventos esportivos rotineiramente alegam grandes benefícios a partir de hospedagem de megaeventos, a esmagadora maioria dos estudos acadêmicos independentes destes eventos têm mostrado que seu impacto econômico parece ser limitado. Embora o impacto bruto desses jogos e torneios enormes seja inquestionável, atraindo dezenas ou centenas de milhares de espectadores ao vivo, bem como em audiências de televisão, que podem chegar aos bilhões, o impacto líquido de megaeventos nas variáveis econômicas reais, tais como bens tributáveis, emprego, renda de pessoas físicas e jurídicas, renda pessoal per capita e a renda em cidades sede é insignificante ${ }^{475}$.
\end{abstract}

Os custos da nova infraestrutura construída para acomodar um evento podem ser substancialmente reduzidos para aumentar significativamente a probabilidade de que um evento resulte em benefícios líquidos positivos ${ }^{476}$. Contudo, é inevitável perceber que os megaeventos fornecem "um excelente exemplo da maneira pela qual a produção do Estado e da política pública urbana tornou-se menos preocupada com a avaliação de políticas públicas dentro de seus próprios termos de referência, e mais preocupada com o contexto macropolítico e os problemas de política neoliberal de competitividade"477.

O investimento em educação, saúde e tecnologia de comunicação, juntamente com um trabalho diversificado e estratégico, é muito mais propenso a ter mais benefícios em longo prazo para o bem-estar econômico e social do que o investimento em eventos de infraestrutura e elites esportivas. Mas, dada a hegemonia do discurso neoliberal na construção da cidade contemporânea, talvez seja apenas muito mais fácil evitar esse debate e assistir as próximas Copas do Mundo ou Jogos Olímpicos ${ }^{478}$.

\footnotetext{
${ }^{472}$ HALL, Michael C. Urban entrepreneurship, corporate interests and sports mega-events: the thin policies of competitiveness within the hard outcomes of neoliberalism. The Editorial Board of the Sociological Review.Published by Blackwell Publishing Ltd. 2006. EUA. p. 61.

${ }^{473}$ MATHESON, Victor. 2006 Op. Cit. p. 10.

${ }^{474}$ HALL, M.C. Op. Cit. p. 64.

475 MATHESON, Victor. 2006 Op. Cit. p. 8

476 MATHESON, Victor. 2006 Op. Cit. p. 19.

${ }^{477}$ HALL, C.M. Op. Cit. 2006. p. 67.

${ }^{478}$ HALL, C.M. Op. Cit. 2006. p. 68.
} 
Assim, parte da literatura é bastante crítica à ideia de que megaeventos sejam referências definitivas de desenvolvimento e de boa escolha política. Por isso, o debate sobre os limites e as condições de sediar um megaevento deve ocorrer de forma madura e ampla, dando margem ao contraditório, e, principalmente, de forma pública.

Entretanto, demonstra-se a seguir o cerceamento democrático de duas formas constitucionais de participação dos Parlamentos: na diplomacia parlamentar e no processo legislativo.

\subsection{O Entrelaçamento Legislativo FIFA/BRASIL}

O entrelaçamento da ordem transnacional da FIFA e da ordem nacional brasileira é um caso que possibilita demonstrar a interação das diferentes forças políticas e econômicas que figuram no atual modus operandi de algumas influências do processo legislativo mundial. Também é um caso particular para a diplomacia parlamentar, uma vez que foi pauta de debates e denúncias relevantes no Congresso Nacional. Assim, para identificar o entrelaçamento legislativo será demonstrada a ponte entre as ordens legislativas nacional e extranacional por meio do equivalente funcional da "iniciativa legislativa" da ordem transnacional à ordem nacional. Para demonstrá-lo, será detalhada a elaboração da Lei Geral da Copa, Lei 12.663/2012.

A eleição do país sede da Copa do Mundo resulta de um processo previamente estabelecido, que exige uma série de compromissos e garantias do governo nacional, ainda prévios à escolha do país sede. Esse processo é chamado pela própria FIFA de Bidding Process, que poderia ser traduzido como "Processo Licitatório"479.

Após a abertura de prazo para a proposição de candidaturas, a FIFA envia o Form of Hosting Agreement (Formulário de Acordo do Anfitrião ou Formulário de Garantias) ${ }^{480}$. Este

\footnotetext{
${ }^{479}$ Bidding Process significa o processo de bidding (licitação ou escolha) e seleção conduzido pela FIFA de acordo com os termos e condições estabelecidos no Bid Registration, para determinar o LOC apontado para o sediar as Competições. In: FIFA. Bidding Agreement. Regarding the Submission of bids for the right to host and stage the 2018 FIFA WORLD CUP or 2022 FIFA WORLD CUP. Zurich, Suíça. p. 37

${ }^{480}$ Hosting Agreement significa o acordo a ser devidamente executado e iniciado pelo LOC, no qual constitui uma obrigação e oferta irrevogável para a FIFA pelo LOC para hospedar e sediar as Competições e na qual, uma vez que contra-assinado pela FIFA, contém os direitos e obrigações chaves do LOC apontados pela FIFA para sediar e hospedar as Competições, nas quais será submetido a FIFA pelo Bidding Committee como parte do Bid Book numa total obediência ao modelo de acordo provido pela FIFA e descrito em sequência no
} 
é um formulário que contém critérios jurídicos e materiais com os quais o governo deve se comprometer, caso seja escolhido como sede da Copa do Mundo e das Confederações. O Form of Hosting Agreement faz parte de um documento maior, que se chama Bid Book ${ }^{481}$, contendo uma série de Bidding Documents ${ }^{482}$ e $o$ Bidding Agreement. Esses documentos são enviados ao Membro Associado.

A Confederação Brasileira de Futebol (CBF) é o membro associado que intermeia a Copa do Mundo de 2014 no Brasil, sendo juridicamente a titular da candidatura do país e responsável pela negociação e encaminhamento do Bidding Agreement. Assim, em $1^{\circ}$ de fevereiro de 2007, a FIFA comunicou abertura das candidaturas e enviou o Form of Hosting Agreement para os membros associados interessados que desejassem sediar a Copa de $2014^{483}$. Esse Form of Hosting Agreement deveria ser entregue até 31 de Julho de 2007.

Nesse documento consta a necessidade de uma Declaração Governamental assinada pelo Presidente da República, além de onze garantias que versam sobre temas distintos e, novamente, precisam ser assinadas pelos respectivos ministros ${ }^{484}$. Essas garantias abordam todos os temas que são de interesse da FIFA. Conforme declaração do Presidente da CBF à época, Ricardo Teixeira, ao encaminhar o Form de Hosting Agreement ao governo brasileiro:

É com grande satisfação que apresento oficialmente a Vossa Excelência (Luís Inácio Lula da Silva) o conjunto de pré-requisitos, no âmbito do Governo Federal, definidos pela FIFA para a realização da Copa do Mundo de 2014 no Brasil. Trata-se de uma praxe da FIFA indicar um rol de medidas de ordem legal e administrativa, sempre aceitas e adotadas pelos

programa 3 desse Bidding Agrement. In: FIFA. Bidding Agreement. Regarding the Submission of bids for the right to host and stage the 2018 FIFA WORLD CUP or 2022 FIFA WORLD CUP. Zurich, Suíça. p. 40.

${ }^{481}$ Bid Book quer dizer um documento a ser submetido à FIFA por um Bid Committee junto com o Membro Associado nos termos desse Bidding Agreement e do Bid Registration. FIFA. Bidding Agreement. Regarding the Submission of bids for the right to host and stage the 2018 FIFA WORLD CUP or 2022 FIFA WORLD CUP .Zurich, Suíça. p. 37. (i) Contendo no seu corpo principal as informações como requeridas e descritas na Cláusula 4 e (ii) Incorporando os Hosting Documents como seus anexos como descrito na cláusula 5.

${ }^{482}$ Bidding Documents significa todos acordos, documentos ou outros materiais a serem submetidos à FIFA pelo Bid Commitee e/ou o Membro Associado em qualquer tempo durante o Bidding Process, incluindo os documentos descritos nesse Bidding Agreement. In: FIFA. Bidding Agreement. Regarding the Submission of bids for the right to host and stage the 2018 FIFA WORLD CUP or 2022 FIFA WORLD CUP. Zurich, Suíça. p. 37.

${ }^{483}$ No caso da Copa do Mundo de 2014, no dia 7 de março de 2003, a FIFA decidiu que os países da América do Sul seriam elegíveis, e no dia 22 de dezembro de 2006 foi confirmado o interesse de Brasil e da Colômbia. ${ }^{484}$ Não há uma tradução oficial do Form of Hosting Agreement. Nesta tese será utilizada como "Formulário de Garantias" pela referência contínua nos debates parlamentares e mídia do termo "garantias". Nos discursos dos parlamentares também é referida como "acordo internacional", "Caderno de Encargos", ou ainda "compromisso FIFA". A dificuldade de tipificação e da natureza jurídica, combinada com a inexistência desse ato internacional na literatura, gera esse tipo de imprecisão de tradução e termos. 
países que conquistaram o triunfo de sediar esse grandioso evento (grifo nosso). ${ }^{485}$

Ricardo Teixeira procura diminuir o impacto do Form of Hosting Agreement nomeando-o de "pré-requisistos" "de praxe". Além disso, destaca-se na afirmação a retórica circular: "sempre são aceitas e adotadas pelos países que conquistaram o triunfo de sediar esse grandioso evento". Irretocável afirmação (sic), uma vez que a recusa do país em assinar os pré-requisitos implicaria não conquistar essa glória, por isso eles são sempre aceitos!

Assim, desde o início são notórias as dificuldades de uma tentativa de negociação das garantias. Ao Brasil, caberia apenas dar garantias, não sendo elas passíveis de negociação ou contrapartida da FIFA Afirma ainda Teixeira:

Diante do exposto e por reconhecer em Vossa Excelência (Luís Inácio Lula da Silva) um líder devotado ao desenvolvimento de nosso País, tenho a mais plena convicção de que o governo sob seu comando se engajará de maneira ativa para que seja possível cumprir os requisitos da FIFA, expressos no chamado Caderno de Encargos, que faço chegar às suas mãos também por essa oportunidade ${ }^{486}$.

O Formulário de Garantias (Form of Hosting Agreement) foi encaminhado pelo Membro Associado do Brasil, a CBF, à Casa Civil da Presidência da República. De acordo com a documentação e manifestações que serão apresentadas a seguir, o Formulário de Garantias não foi debatido em nenhuma outra instância democrática brasileira, tampouco se deu conhecimento da missão diplomática ou reunião interministerial. Diferentemente de acordos internacionais ou todo ato internacional, esse documento foi exclusivamente encaminhado pela FIFA à CBF e, finalmente, ao Brasil. No Brasil, foi assinado pelo Presidente da República e Ministros dos temas das respectivas garantias.

Sendo assim, a primeira dúvida importante que surge diz respeito à natureza jurídica do Formulário de Garantias. Como também será observado, ele terá duas funções fundamentais no processo de entrelaçamento legislativo: equivalente funcional e retórica. Ele será o equivalente funcional de iniciativa legislativa da FIFA no processo legislativo nacional brasileiro. Além disso, é uma peça fundamental para o convencimento político no debate parlamentar e público no Congresso Nacional.

\footnotetext{
${ }^{485}$ CONFEDERAÇÃO BRASILEIRA DE FUTEBOL. BID BOOK. Declaração de Ricardo Teixeira. p. 3-4. Rio de Janeiro, 13 de abril de 2007.

${ }^{486}$ Continua (Ricardo Teixeira): (...) para se ter noção da amplitude de uma Copa, estudos da FIFA indicam que a Copa de 2006, na Alemanha, foi assistida por uma Audiência global de 30 bilhões de espectadores. Grifo nosso. In:CONFEDERAÇÃO BRASILEIRA DE FUTEBOL. BID BOOK. Declaração de Ricardo Teixeira. P. 3-4. Rio de Janeiro, 13 de abril de 2007.
} 
Contudo, ele é um ato internacional desconhecido e sui generis por não se enquadrar nos tradicionais instrumentos de direito internacional público ou privado. Ele não é um instrumento negociado, mas apenas assinado. A FIFA escreveu todos os termos. A assinatura do Formulário de Garantias pelos Ministros de Estado e pelo Presidente da República não foi encaminhada ao Congresso Nacional para aprovação, como determina a Constituição Federal em caso de tratados, acordos ou atos internacionais. ${ }^{487}$.

Qualquer debate público em torno desse Formulário de Garantias ocorre apenas quando é traduzido e encaminhado em forma de lei. De modo análogo, após a assinatura do tratado, geralmente feita pelo Presidente da República, envia-se o documento através de mensagem à Câmara dos Deputados, acompanhado de exposição de motivos pelo Ministério de Relações Exteriores.

Após a apreciação e deliberação da Comissão de Relações Exteriores da Câmara dos Deputados, será formulado um projeto de Decreto Legislativo de aprovação ou rejeição, seguida de apreciação da Comissão de Justiça e outras Comissões da Casa que, conforme o tema do tratado, devam opinar sobre ele, da apreciação e deliberação em plenário e do envio do projeto de Decreto Legislativo ao Senado Federal ${ }^{488}$.

$\mathrm{Na}$ análise de tratados, acordos ou atos internacionais assinados pelo Executivo, as Comissões e ambas as casas do Legislativo Federal, Câmara e Senado, obedecem ao processo legislativo ordinário, podendo aprová-los ou não, propor reservas a cláusulas específicas, mas de maneira alguma acrescentar emendas. Podem até mesmo rejeitá-lo integralmente.

A aprovação de um ato internacional pelo parlamento federal brasileiro é realizada através do decreto legislativo. O fato é então comunicado ao Presidente da República, que procederá imediatamente à sua ratificação, informando à parte igualmente celebrante do tratado, ou ao depositário da convenção bilateral, que os trâmites internos foram satisfatoriamente concluídos. Entretanto, para sua efetiva validade interna, é ainda necessário que ele seja publicado no Diário Oficial da União, fato que torna, através do ato promovido

\footnotetext{
${ }^{487}$ De acordo com o disposto na Constituição Federal, art. 84, VIII, compete privativamente a "Presidente da República celebrar tratados, convenções e atos internacionais, sujeitos a referendo do Congresso Nacional". Em complemento, o texto constitucional expressa no art. 49, I, que "é da competência exclusiva do Congresso Nacional resolver definitivamente sobre tratados, acordos ou atos internacionais que acarretem encargos ou compromissos gravosos ao patrimônio nacional." In: BRASIL. CONSTITUIÇÃO DA REPÚBLICA FEDERATIVA DO BRASIL (1988). BRASIL. Artigo 49, I, .

${ }^{488}$ VENTURA, Deisy; SEITENFUS, Ricardo Antônio Silva. Introdução ao direito internacional público. $3^{\mathrm{a}}$ Ed. rev. ampl. Porto Alegre: Livraria do Advogado, 2003. p. 44-45.
} 
pelo Presidente da República, finalmente aplicáveis os seus dispositivos com força de direito positivo $^{489}$.

Foi esse o caminho legislativo do Formulário de Garantias da FIFA. Contudo, resta indefinida a tipificação desse ato/tratado internacional, que habitualmente a diplomacia e a literatura preveem em suas hipóteses.

Como ato jurídico internacional, os tratados só podem ser concluídos por entes capazes de contrair direitos e obrigações no âmbito externo. Além dos Estados, há bastante reticência quanto à capacidade de um órgão não estatal de assumir uma obrigação internacional convencional, em função do requisito da personalidade jurídica internacional ${ }^{490}$. As organizações internacionais, como a ONU e a OEA, a partir de 1986, com o advento da Convenção de Viena sobre Direito dos Tratados entre Estados e Organizações Internacionais ou entre Organizações Internacionais, passaram a também ter capacidade internacional de celebrar tratados ${ }^{491}$. Ademais, não se trata propriamente de um tratado, nem mesmo de um contrato internacional com a administração pública, o que solucionaria o problema da personalidade jurídica internacional, uma vez que um contrato com um ator privado prevê contrapartidas para o Estado-parte. No Formulário de Garantia não consta, porém, qualquer contrapartida da FIFA. É apenas um rol de garantias do Brasil à FIFA.

Caso fosse entendido como um "ato internacional", a expressão geralmente é entendida em dois sentidos: a) em sentido amplo, englobando não apenas ato formado pelo consentimento mútuo dos Estados, mas também atos unilaterais ${ }^{492}$; b) um restrito, que seria

\footnotetext{
489 CACHAPUZ DE MEDEIROS, Antonio Paul. 1995.

490 A personalidade jurídica internacional não se dá por qualquer processo administrativo, como no plano nacional. Assim, não existe um sistema propriamente instituído para reconhecer e registrar associações como pessoas jurídicas no nível internacional. Dessa forma, o critério utilizado é funcional. Os critérios para aferição da personalidade jurídica das organizações internacionais podem ser resumidos da seguinte forma: (a) uma associação permanente de Estados, que persegue fins lícitos, dotada de órgãos próprios; (b) uma distinção, em termos de poderes e fins jurídicos, entre a organização e os seus Estados-membros; (c) a existência de poderes jurídicos que possam ser exercidos no plano internacional, e não unicamente no âmbito dos sistemas nacionais de um ou mais Estados; (d) uma organização pode existir, mas não possuir os órgãos e objetivos necessários para ter personalidade jurídica como tal. Se uma organização goza de uma independência considerável e do poder de intervir nos assuntos dos Estados-membros, estes podem vir a ter um estatuto semelhante ao de membro de uma união federal. In: BROWNLIE, Ian. Princípios de Direito Internacional Público. Lisboa: Fundação Calouste Gulbenkian, 1997. P. 708-710.

491 A primeira Convenção de Viena sobre o Direito dos Tratados, de 1969, teve como uma de suas primeiras preocupações definir precisamente o que se entende por tratado internacional. Em seu art. $2^{\circ}$, ela o define como um "acordo internacional celebrado por escrito entre Estados e regido pelo direito internacional, quer conste de um instrumento jurídico único, quer de dois ou mais instrumentos conexos, qualquer que seja sua denominação particular" (art. 2º, I, alínea a). CONVENÇÃO DE VIENA SOBRE O DIREITO DOS TRATADOS, 1969,p. 23. BRASIL, Ministério Das Relações Exteriores do Brasil, DAI - Divisão de Atos Internacionais. Prática Diplomática Brasileira - Manual de Procedimentos. Brasília, maio de 2010.

492 "Os atos unilaterais propriamente ditos emanam da vontade estatal, obedecem às motivações que ditam o comportamento externo dos governos, independentemente de obrigações convencionais ou consuetudinárias
} 
aquele tipo de tratado que criaria regra de direito ${ }^{493}$. Dentre os atos internacionais que criam direito, o Ministério das Relações Exteriores do Brasil considera como denominações que podem designar atos as seguintes: tratado ${ }^{494}$, convenção ${ }^{495}$, acordo ${ }^{496}$, ajuste ou acordo complementar $^{497}$, protocolo $^{498}$, memorando de entendimento ${ }^{499}$, convênio ${ }^{500}$, acordo por troca de $\operatorname{notas}^{501}$.

anteriores." In: AMARAL JÚNIOR,Alberto do. Curso de Direito Internacional Público. $2^{\mathrm{a}}$ Ed. São Paulo:Editora Atlas, 2011. p. 144.

${ }^{493}$ MAZZUOLI, Valério de Oliveira. Curso de direito internacional público. São Paulo: RT. 2010.

${ }^{494}$ A expressão tratado foi escolhida pela Convenção de Viena sobre o Direito dos Tratados de 1969 como termo para designar, genericamente, um acordo internacional. Denomina-se tratado o ato bilateral ou multilateral ao qual se deseja atribuir especial relevância política. Nessa categoria se destacam, por exemplo, os tratados de paz e amizade, o Tratado da Bacia do Prata, o Tratado de Cooperação Amazônica, o Tratado de Assunção, que criou o Mercosul, o Tratado de Proibição Completa dos Testes Nucleares. In: BRASIL, Ministério Das Relações Exteriores do Brasil, DAI - Divisão de Atos Internacionais. Prática Diplomática Brasileira - Manual de Procedimentos. Brasília, maio de 2010.

${ }^{495}$ Num nível similar de formalidade, costuma ser empregado o termo Convenção para designar atos multilaterais, oriundos de conferências internacionais e que versem sobre assunto de interesse geral, como, por exemplo, as convenções de Viena sobre relações diplomáticas, relações consulares e direito dos tratados; as convenções sobre aviação civil, sobre segurança no mar, sobre questões trabalhistas. É um tipo de instrumento internacional destinado, em geral, a estabelecer normas para o comportamento dos Estados em uma gama cada vez mais ampla de setores. No entanto, existem algumas - poucas é verdade - Convenções bilaterais, como a Convenção destinada a evitar a dupla tributação e prevenir a evasão fiscal celebrada com a Argentina (1980) e a Convenção sobre Assistência Judiciária Gratuita celebrada com a Bélgica (1955). In: BRASIL, Op. Cit. 2010.

${ }^{496} \mathrm{O}$ acordo leva o nome de Ajuste ou Acordo Complementar quando o ato dá execução a outro, anterior, devidamente concluído. Em geral, são colocados ao abrigo de um acordo-quadro ou acordo-básico dedicados a grandes áreas de cooperação (comércio e finanças, cooperação técnica, científica e tecnológica, cooperação cultural e educacional). Esses acordos criam o arcabouço institucional que orientará a execução da cooperação. O Brasil tem feito amplo uso desse termo em suas negociações bilaterais de natureza política, econômica, comercial, cultural, científica e técnica. Acordo é expressão de uso livre e de alta incidência na prática internacional, embora alguns juristas entendam por acordo os atos internacionais com reduzido número de participantes e importância relativa. No entanto, um dos mais notórios e importantes tratados multilaterais foi assim denominado: Acordo Geral de Tarifas e Comércio (GATT). In: BRASIL, Op. Cit. 2010.

${ }^{497}$ É o ato que dá execução a outro, anterior, devidamente concluído e em vigor, ou que detalha áreas de entendimento específicas, abrangidas por aquele ato. Por este motivo, são usualmente colocados ao abrigo de um acordo-quadro ou acordo-básico. In: BRASIL, Op. Cit. 2010.

${ }^{498}$ Protocolo é um termo que tem sido usado nas mais diversas acepções, tanto para acordos bilaterais quanto para multilaterais. Ele aparece designando acordos menos formais que os tratados, ou acordos complementares ou interpretativos de tratados ou convenções anteriores. É utilizado ainda para designar a ata final de uma conferência internacional. Muitas vezes tem sido usado, na prática diplomática brasileira, sob a forma de "protocolo de intenções", para sinalizar um início de compromisso. In: BRASIL, Op. Cit. 2010.

${ }^{499}$ Designação comum para atos redigidos de forma simplificada, destinados a registrar princípios gerais que orientarão as relações entre as Partes, seja nos planos político, econômico, cultural ou em outros. O memorando de entendimento é semelhante ao acordo, com exceção do articulado, que deve ser substituído por parágrafos numerados com algarismos arábicos. Seu fecho é simplificado. Na medida em que não crie compromissos gravosos para a União, pode normalmente entrar em vigor na data da assinatura. In: BRASIL, Op. Cit. 2010.

${ }^{500} \mathrm{O}$ termo convênio, embora de uso frequente e tradicional, padece do inconveniente do uso que dele faz o direito interno. Seu uso está relacionado a matérias sobre cooperação multilateral de natureza econômica, comercial, cultural, jurídica, científica e técnica, como o Convênio Internacional do Café; o Convênio de Integração Cinematográfica Ibero-Americana; o Convênio Interamericano sobre Permissão Internacional de Radioamador. Também se denominam "convênios" acertos bilaterais, como o Convênio de Cooperação Educativa, celebrado com a Argentina (1997); o Convênio para a Preservação, Conservação e Fiscalização de 
O Protocolo de Garantias assinado pelo Brasil que proporcionou a candidatura da CBF também não se encaixa formalmente em nenhum desses atos. Em todo o rol de atos internacionais relacionados pela literatura, pela Constituição, pela Convenção de Viena Sobre o Direito dos Tratados e pelo Governo, não é encontrado um ato internacional como o referido Protocolo de Garantias de um Estado soberano a uma organização privada ${ }^{502}$.

Figuram também como forma de atos internacionais os executive agreements ou acordos executivos ou ainda, os acordos internacionais de forma simplificada. "Os acordos executivos (executive agreements) são negociações entre poderes executivos e não necessitam de ratificação legislativa, sendo incorporados por meio de edição de medidas provisórias. Essa é uma forma de evasão e distanciamento do Legislativo das questões de política externa."503

Mesmo que possam ser entendidos como uma forma de evasão e distanciamento, esses acordos são limitados a protocolos complementares, memorandos de entendimentos, atas ou declarações, isto é, a compromissos relativamente menores. "A forma mais comum de celebração dos acordos de forma simplificada é a troca de notas diplomáticas, em que os pactuantes desdobram o acordo de vontades em textos produzidos no mesmo momento ou em momentos diversos, cada um deles firmado em nome de uma das partes apenas."

Isso não quer dizer que eles sejam menos frequentes. Ao contrário, os instrumentos diplomáticos simplificados são utilizados amplamente pelo Ministério de Relações Exteriores:

De 1988 a 2007 de um total de 1.821 atos internacionais estabelecidos em formato bilateral, 1.423 ocorreram em formato simplificado, ou seja, entraram em vigor imediatamente após a assinatura do instrumento via "acordos executivos", o que corresponde a $78 \%$ do total. Já os atos multilaterais estabelecidos pelo Brasil entre os anos de 1988 a 2007 apresentaram em sua maioria necessidade de tramitação completa, ou seja, a utilização dos chamados "Acordos Executivos" no estabelecimento de compromissos multilaterais é menos frequente no Brasil. De 285 atos internacionais multilaterais estabelecidos (1988-2007), apenas 21 foram

Recursos Naturais nas Áreas de Fronteira, celebrado com a Bolívia (1980); o Convênio Complementar de Cooperação Econômica no Campo do Carvão, celebrado com a França (1981). In: BRASIL, Op. Cit. 2010.

${ }^{501}$ Emprega-se a troca de notas diplomáticas, em princípio, para assuntos de natureza administrativa, bem como para alterar ou interpretar cláusulas de atos já concluídos. Não obstante, o escopo desses acordos vem sendo ampliado. Seu conteúdo estará sujeito à aprovação do Congresso Nacional sempre que incorrer nos casos previstos pelo Artigo 49, inciso I, da Constituição. Quanto à forma, as notas podem ser: a) idênticas (com pequenos ajustes de redação), com o mesmo teor e data; b) uma primeira nota, de proposta, e outra, de resposta e aceitação, que pode ter a mesma data ou data posterior. In: BRASIL, Op. Cit. 2010.

${ }_{502}$ CACHAPUZ DE MEDEIROS, Antonio Paul. 1995; AMARAL JÚNIOR,Alberto do. Op. Cit. 2011. MAZZUOLI, Valério de Oliveira. Op. Cit. 2001.

${ }^{503}$ NEVES, João Augusto de Castro. O papel do legislativo nas negociações do Mercosul e da Alca. Contexto Internacional. Vol. 25 n. 1 Rio de Janeiro Jan/Junho de 2003.

${ }^{504}$ CACHAPUZ DE MEDEIROS, Antonio Paul. 1995. P. 431. 
realizados por tramitação simplifica, sendo que 264, ou seja, 93\% deles passaram pela anuência do Congresso Nacional brasileiro ${ }^{505}$.

Contudo, a Constituição Federal de 1988 não excepcionou a regra do art. 49 aos acordos de forma simplificada. Eles deixam de ser "simplificados" sempre que acarretarem encargos ou compromissos gravosos ao patrimônio nacional, sendo necessário, portanto, serem aprovados pelo Congresso Nacional. O Formulário de Garantias, como será demonstrado, acarreta encargos e compromissos para o Brasil em inúmeras áreas de políticas públicas, além de alterações legislativas significativas, isenções fiscais e investimentos de diversas ordens e valores. Ele não pode, assim, ser tratado como um executive agreeement.

Dessa forma, fica evidenciada a figura jurídica sui generis, sem previsão constitucional ou legal do Formulário de Garantias da FIFA. Embora o presidencialismo brasileiro seja concentrado, não cabe ao Poder Executivo tomar nenhuma decisão de cunho internacional (com ônus) sem a aprovação parlamentar. Nesse caso em particular, também não houve intermediação do Ministério das Relações Exteriores, do Congresso Nacional, ou a participação de qualquer órgão de fiscalização, legislativo ou da própria participação popular.

Assim, fica evidenciado que o Formulário de Garantias assinado pelo Brasil por ocasião da sua candidatura viola o art. 49, inciso i, da Constituição da República. Contudo, a proposição de sua inconstitucionalidade fica prejudicada pelo seu teor retórico e equivalente funcional simbólico da FIFA ao Brasil. Ele é utilizado como evidência material para a base da formulação da Lei Geral da Copa e também como discurso para sua aprovação. Mas não deixa de ser inconstitucional. Esse é um dos motivos que impossibilita a caracterização de um entrelaçamento legislativo transconstitucional, sendo, portanto, um entrelaçamento com corrupção sistêmica.

\subsubsection{A Iniciativa Legislativa}

Diferentemente de um tratado e da grande maioria dos atos internacionais, não houve missão diplomática ou participação do Ministério das Relações Exteriores ou de qualquer outra delegação brasileira em todo processo de candidatura do Brasil às competições. Pelas evidências dos documentos do Form of Hosting Agreement - Formulário de Garantias -,

${ }^{505}$ FIGUEIRA, A.C.R. Processo Decisório em Política Externa no Brasil. Tese de doutorado. Faculdade de Filosofia, Letras e Ciências Humanas: Universidade de São Paulo: São Paulo. (2009). p. 130. 
ele foi recebido pelo governo brasileiro, que o encaminhou a todos os ministérios competentes, com o único objetivo de carimbá-los e assiná-los. O Formulário de Garantias era composto por onze garantias governamentais e a declaração presidencial.

Abaixo, pode ser observado um sumário da sua cronologia até se tornar a Lei Geral da Copa 12.663/2012.

\begin{tabular}{|c|c|c|c|}
\hline \multicolumn{4}{|c|}{ Cronologia do Entrelaçamento FIFA/BRASIL } \\
\hline Ano & Eventos & Nível de Participação & $\begin{array}{l}\text { Processo } \\
\text { Legislativo }\end{array}$ \\
\hline 2007 & $\begin{array}{l}\text { A CBF demonstra } \\
\text { interesse formal em } \\
\text { sediar a Copa para } \\
\text { FIFA }\end{array}$ & Ato unilateral da $\mathrm{CBF}$ & Iniciativa \\
\hline 2007 & $\begin{array}{l}\text { FIFA ENVIA o Bid } \\
\text { Book e Agreement } \\
\text { com o Form of } \\
\text { Hosting Agreement } \\
\text { (Formulário de } \\
\text { Garantias) para a } \\
\text { CBF }\end{array}$ & Ato unilateral da FIFA & \\
\hline 2007 & $\begin{array}{l}\text { CBF encaminha o } \\
\text { Formulário de } \\
\text { Garantias ao Brasil }\end{array}$ & $\begin{array}{l}\text { Primeira participação do } \\
\text { nível nacional. Acesso } \\
\text { apenas a Casa Civil da }\end{array}$ & \\
\hline 2007 & $\begin{array}{l}\text { Brasil assina o } \\
\text { Formulário de } \\
\text { Garantias (Form of } \\
\text { Hosting Agreement). }\end{array}$ & $\begin{array}{l}\text { Presidência da República } \\
\text { e aos Ministros, que } \\
\text { assinam o Formulário de } \\
\text { Garantias, (Form of } \\
\text { Hosting Agreement) }\end{array}$ & \\
\hline 2011 & $\begin{array}{l}\text { Brasil encaminha } \\
\text { integralmente o } \\
\text { Formulário de } \\
\text { Garantias ao }\end{array}$ & $\begin{array}{l}\text { O debate chega ao } \\
\text { Congresso Nacional. } \\
\text { Deputados alegam não ter } \\
\text { acesso ao Formulário de }\end{array}$ & Debate \\
\hline
\end{tabular}




\begin{tabular}{|c|c|c|c|}
\hline & Congresso Nacional. & Garantias. & \\
\hline & $\begin{array}{l}\text { Cria-se a Comissão } \\
\text { Especial para a Lei, } \\
\text { que modifica por } \\
\text { três vezes o projeto } \\
\text { inicial. }\end{array}$ & $\begin{array}{l}\text { Relator Deputado Vicente } \\
\text { Cândido. Diversos } \\
\text { deputados se manifestam. } \\
\text { São propostas de } \\
\text { realizadas públicas. }\end{array}$ & \\
\hline & $\begin{array}{l}\text { Na Câmara dos } \\
\text { Deputados é o } \\
\text { Projeto de Lei } \\
2.330 / 2011 .\end{array}$ & $\begin{array}{l}\text { O Plenário da Câmara } \\
\text { sugere } 66 \text { emendas, sendo } \\
15 \text { aprovadas. }\end{array}$ & \multirow[t]{2}{*}{ Aprovação } \\
\hline 2012 & $\begin{array}{l}\text { Projeto de Lei Geral } \\
\text { da Copa chega no } \\
\text { Senado PLC } \\
\text { 10/2012. }\end{array}$ & $\begin{array}{l}\text { O Plenário do Senado } \\
\text { propõe } 38 \text { emendas, } \\
\text { sendo } 5 \text { aprovadas. }\end{array}$ & \\
\hline 2012 & $\begin{array}{l}\text { O Projeto sofre } \\
\text { vetos da Presidente, } \\
\text { mas o texto é } \\
\text { sancionado como a } \\
\text { Lei Geral da Copa, } \\
\text { 12.663/2012 } \\
\text { publicado no dia } 8 \\
\text { de Junho de } 2012 \text {. }\end{array}$ & $\begin{array}{l}\text { Aprovada a Lei Geral da } \\
\text { Copa. Duas ações de } \\
\text { ADIN são propostas } \\
\text { contra a Lei. }\end{array}$ & Sanção/Publicação \\
\hline
\end{tabular}

Durante todo o trâmite legislativo, observa-se uma surpreendente ausência do Ministério de Relações Exteriores. Esse Ministério, da mesma forma que toda estrutura institucional brasileira, não teve acesso ao Formulário de Garantias em momento algum. Naturalmente, esse foi o primeiro lugar em que se deu início a busca pelos documentos originais do Formulário de Garantias assinado pelo Brasil. Mas o MRE não teve acesso, como indica o e-mail seguinte, endereçado ao candidato pelo Itamaraty:

Prezado Cícero Krupp da Luz, Encaminhamos, a seguir, resposta elaborada pela Coordenação-Geral de Intercâmbio e Cooperação Esportiva (CGCE/SGEC/G): 
"A Coordenação-Geral de Intercâmbio e Cooperação Esportiva (CGCE) deste Ministério não teve acesso às solicitações da FIFA. Durante as negociações do Governo brasileiro com a FIFA sobre sediar eventos da referida entidade, que foram centralizadas na Casa Civil da Presidência da República, foram solicitados ao Itamaraty subsídios sobre o regime de concessão de vistos e critérios para execução de hinos e hasteamento de bandeiras nacionais. Foram essas as áreas temáticas sobre as quais 0 Itamaraty contribui com subsídios, que posteriormente foram utilizados na elaboração da chamada 'Lei Geral da Copa"'.

Atenciosamente,

Serviço de Informação ao Cidadão

Ministério das Relações Exteriores (informação pessoal) ${ }^{506}$.

Conforme atesta o Ministério das Relações Exteriores, apenas a Casa Civil teve acesso ao Formulário de Garantias. De forma análoga ocorreu com o Congresso Nacional. Nem mesmo os deputados e senadores que participaram da Comissão Especial Para Lei Geral da Copa (Projeto de Lei $\mathrm{n}^{\circ}$ 2330) tiveram acesso integral aos documentos. ${ }^{507}$

O Deputado Chico Alencar (PSOL-RJ), líder do PSOL na Câmara, declarou ter requerido esses compromissos e garantias da FIFA, porém sem êxito:

Nós não podemos colocar o Instituto Nacional de Propriedade Industrial como órgão carimbador dos produtos que a FIFA definir como de seu interesse e de seu monopólio. Nós não podemos ficar no desconhecimento e eu solicitei, como Líder do PSOL, há muito tempo, isso ao Governo sobre a carta-compromisso do Governo brasileiro com a FIFA, realizada há 2 anos, em que parece que a soberania nacional fica secundarizada ${ }^{508}$.

Portanto, a Lei Geral da Copa é "Estado futebolístico de exceção" e negação da soberania nacional. Essa é a posição do PSOL, que vamos defender lá na Comissão, como já o fizemos, e aqui em Plenário ${ }^{509}$.

Um mês depois, o Deputado Alencar reiterava sua inconformidade:

Em janeiro fiz um ofício pedindo à Casa Civil a integridade desses documentos. $E$ depois um requerimento de informações que não foi respondido. Portanto, quando se fala aqui que a FIFA exigiu isso, que o Governo se comprometeu com aquilo, nós, Parlamento, estamos tendo

\footnotetext{
${ }^{506}$ BRASIL. Ministério das Relações Exteriores. Sistema Eletrônico de Serviço ao cidadão. Protocolo: 09200.000283/2013-31. Mensagem recebida por ciceroluz@gmail.com em 12/7/2013.

${ }^{507}$ Além do Presidente da Câmara dos Deputados Deputado Marco Maia (PT/RS), também foram contatados os seguintes deputados com o fim de encontrar o "Formulário de Garantias" (nenhum deles teve acesso da mesma maneira): Deputado Dr. Rosinha (PT/PR); Deputado José Stédile (PSB/RS); Deputado Romário (PSB/RJ).

${ }^{508}$ BRASIL. DIÁRIO DA CAMARA DOS DEPUTADOS. Deputado CHICO ALENCAR (PSOL-RJ). Data: 28/02/2012.

${ }^{509}$ BRASIL. DIÁRIO DA CAMARA DOS DEPUTADOS. Deputado CHICO ALENCAR (PSOL-RJ). Data: 28/02/2012.
} 
essas informações sonegadas. E é um acocoramento inaceitável operar com ouvi dizer ou com que o Governo assinou à revelia do Parlamento ${ }^{510}$.

Os deputados Edio Lopes (PMDB-RR) e Cesar Colnago (PSDB-ES) também se manifestaram durante a primeira audiência da Comissão Especial, solicitando cópia do Formulário de Garantias que contivesse todas as exigências da Fifa para a realização da Copa no Brasil, a ser enviada à comissão. ${ }^{511}$

Outras declarações de deputados evidenciam o desconhecimento do conteúdo e da forma como havia sido concebido o Formulário de Garantias. Como na declaração do deputado Édio Lopes (PMDB/RR): "Vicente Candido, senhor relator: a proposta (da Lei Geral da Copa) é uma síntese do protocolo assinado entre o governo e a FIFA. Na negociação do projeto de lei, nós vamos romper protocolos previamente acertados com a FIFA? Foi acertado que romperíamos certas regras internas para poder sediar esse evento?"512 O deputado Cesar Colnago (PSDB/ES) também questionou a relação dos Compromissos e da FIFA. "Será que o governo negociou mal com a FIFA? Se alguém negociou algo que fere os nossos direitos fundamentais e sociais, negociou mal". 513

Ao responder os questionamentos, o relator da proposta, deputado Vicente Candido (PT-SP), disse que já havia tido acesso ao documento (Formulário de Garantias) e que o PL 2330/11 era uma síntese do protocolo assinado entre a FIFA e o governo brasileiro. Porém, afirmou que isso não impediria que a proposta fosse alterada, afirmando: "Estamos cobrindo uma lacuna da falta de discussão do governo com a sociedade civil". 514

Mas o desconhecimento e a falta dos documentos pelos deputados não foram fatos isolados. O próprio Presidente da Câmara dos Deputados, Marco Maia (PT/RS), declarou que não havia tido acesso aos documentos requeridos (Formulário de Garantias ou Form of Hosting Agreement e outros) e aconselhou a requerer ao Ministério dos Esportes. O momento de busca pelo Formulário de Garantias tomava ares kafkanianos:

Prezado Cícero Krupp da Luz, Boa tarde, em relação ao seu requerimento sobre o acesso aos documentos referentes ao Termo de Compromisso assinado entre o Governo Brasileiro e a FIFA, eu o encaminhei à consideração do Dep. Renan Filho, presidente da comissão. Em despacho, S.Ex ${ }^{a}$ ponderou que o documento pertence ao Ministério de Estado do Esporte. Assim, sugiro que você se dirija à Secretaria Nacional de Futebol e Defesa dos Direitos do Torcedor e à Secretaria Nacional de

\footnotetext{
510 BRASIL. DIÁRIO DA CAMARA DOS DEPUTADOS. Deputado CHICO ALENCAR (PSOL-RJ). Data: 28/03/2012.

511 JORNAL DA CAMARA. Lara Haje. Brasília, 3 de Novembro de 2011. P. 5.

512 JORNAL DA CAMARA. Lara Haje. Brasília, 3 de Novembro de 2011. P. 5.

513 JORNAL DA CAMARA. Lara Haje. Brasília, 3 de Novembro de 2011. P. 5.

514 JORNAL DA CAMARA. Lara Haje. Brasília, 3 de Novembro de 2011. P. 5.
} 
Esporte de Alto Rendimento e encaminhe seu requerimento para esses órgãos do Ministério do Esporte. Grato! Mario Drausio Coutinho, secretário ${ }^{515}$. (informação pessoal)

Novamente, o Ministério dos Esportes também alega não ter os documentos. Contudo, indica, finalmente, um caminho de sucesso: Serviço de Informação ao Cidadão - SIC ${ }^{516}$. Dessa forma, por meio de um requerimento formal à instituição, o Formulário de Garantias foi disponibilizado para essa pesquisa sob o direito da Lei de Acesso à Informação, Lei $n^{\circ}$ 12.527/2011, e graças ao Sistema Eletrônico de Serviço ao Cidadão ${ }^{517}$.

O compromisso foi utilizado pelo governo federal como retórica e argumento de autoridade, fundado na irreversibilidade de um instrumento jurídico internacional. A seguir, apresentam-se todas as garantias e os respectivos Ministros de Estados que a assinaram, reproduzindo ipsis litteris o Formulário de Garantias (Form of Hosting Agreement) que a FIFA enviou ao Brasil:

\author{
Garantia $N^{\circ}$ 1: Permissões para Entrada e Saída ${ }^{518}$ \\ Garantia No 2: Permissões de Trabalho ${ }^{519}$ \\ Garantia $\mathrm{N}^{\mathrm{o}} 3$ : Direitos Alfandegários e Impostos ${ }^{520}$ \\ Garantia No 4: Isenção Geral de Impostos ${ }^{521}$ \\ Garantia No 5: Segurança e Proteção 522 \\ Garantia No 6: Bancos e Câmbio ${ }^{523}$
}

\footnotetext{
515 BRASIL. Ministério dos Esportes. Mensagem enviada por <mario.coutinho@camara.gov.br>e recebida por ciceroluz@gmail.com em 04/05/12.

516 Prezado Senhor Cícero Krupp da Luz. Solicitamos a Vossa Senhoria encaminhar sua mensagem para o Serviço de Informação ao Cidadão - SIC deste Ministério, localizado no endereço abaixo: Ministério do Esporte / SIC. Esplanada dos Ministérios, Bloco "A" térreo sala T-20 Brasília - DF. CEP: 700-54-906. <www.acessoainformacao.gov.br ><http://www.acessoainformacao.gov.br/sistema/> Atenciosamente, Ouvidoria-Geral Ministério do Esporte (informação pessoal). Mensagem recebida por ciceroluz@gmail.com em 25/06/13.

517 BRASIL. Lei de Acesso à Informação. Especificamente pelo Sistema Eletrônico de Serviço ao cidadão, protocolos 09200.000283/2013-31: Mesmo que o direito de acesso à informação pública esteja previsto na Constituição Federal, no inciso XXXIII do Capítulo I - dos Direitos e Deveres Individuais e Coletivos: "todos têm direito a receber dos órgãos públicos informações de seu interesse particular, ou de interesse coletivo ou geral, que serão prestadas no prazo da lei, sob pena de responsabilidade, ressalvadas aquelas cujo sigilo seja imprescindível à segurança da sociedade e do Estado".

518 BRASIL. Ministério de Estado das Relações Exteriores. Ministro Celso Amorim. Garantia № 1 : Permissões para Entrada e Saída. 28 de maio de 2007.

${ }^{519}$ BRASIL. Ministério de Estado do Trabalho e Emprego. Garantia No2: Permissões de Trabalho. Ministro Ronaldo Lessa (interino). Carta No 287 / GM. 14 de junho de 2007.

${ }^{520}$ BRASIL. Ministério de Estado da Fazenda. Garantia No 3: Direitos Alfandegários e Impostos. Ministro Guido Mantega. Junho de 2007 (sem referência ao dia).

${ }^{521}$ BRASIL. Ministério de Estado da Fazenda. Garantia No 4: Isenção Geral de Impostos. Ministro Guido Mantega. Junho de 2007 (sem referência ao dia).

${ }^{522}$ BRASIL. Ministério de Estado de Justiça. Garantia No 5: Segurança e Proteção. Ministro Tarso Genro.29 de maio de 2007.
} 
Garantia N ${ }^{\circ}$ 7: Procedimentos de Imigração, Alfândega e Check-in ${ }^{524}$

Garantia No 8: Proteção e Exploração de Direitos Comerciais ${ }^{525}$

Garantia No 9 : Hinos e Bandeiras Nacionais ${ }^{526}$

Garantia No 10: Indenização 527

Garantia No 11: Telecomunicações, Tecnologia da Informação ${ }^{528}$

Após serem assinadas pelos Ministros de Estados, entre maio e junho de 2007, foram enviadas à FIFA, protocolando sua candidatura. No dia 30 de outubro de 2007, o Brasil foi escolhido sede da Copa das Confederações 2013 e da Copa do Mundo de $2014^{529}$.

O Protocolo de Garantias foi apresentado à Câmara dos Deputados como Projeto de Lei 2.330/2011, por meio da Mensagem 389 da Presidente da República. Na Exposição de Motivos No 15 do Projeto de Lei, de 16 de Setembro de 201, ressalta-se três menções:

"O Projeto de Lei Geral, dessa forma, atende aos compromissos assumidos pelo Brasil com a FIFA. Está, pois, apto a ser enviado ao Congresso Nacional." (grifo nosso).

“2. Tais medidas se fazem necessárias para a efetivação dos compromissos assumidos pelo Governo Federal perante a FIFA, quando da escolha do País como sede das Competições."

"9. O Projeto de Lei Geral, dessa forma, atende aos compromissos assumidos pelo Brasil com a FIFA. Está, pois, apto a ser enviado ao Congresso Nacional." ${ }^{, 30}$

${ }^{523}$ BRASIL. Ministério de Estado da Fazenda. Garantia N. ${ }^{\circ}$ 6: Bancos e Câmbio. Ministro Guido Mantega. Junho de 2007 (sem referência de dia).

${ }^{524}$ BRASIL. Ministério de Estado da Fazenda, Guido Mantega, Ministério do Estado da Justiça, Tarso Genro e Ministério de Estado da Defesa, Waldir Pires. Garantia N.7: Procedimento de Imigração, Alfândega e Check-in. Respectivamente: Guido Mantega, Tarso Genro, Waldir Pires. Junho de 2007 (sem referência de dia).

525 BRASIL. Ministério de Estado de Justiça, Ministério de Estado do Desenvolvimento, Indústria e Comércio Exterior, Ministério de Estado da Cultura, Ministério de Estado da Ciência e Tecnologia. Garantia N.8: Proteção e Exploração de Direitos Comerciais. Respectivamente: Tarso Genro, Miguel Jorge, João Luiz Silva Ferreira, Sergio Machado Rezende. 29 de maio de 2007.

${ }^{526}$ BRASIL. Ministério de Estado das Relações Exteriores. Ministro Celso Amorim. Garantia No 9: Hinos e Bandeiras Nacionais. 28 de maio de 2007.

${ }^{527}$ BRASIL. Ministro de Estado da Advocacia Geral da União. Garantia No 10: Indenização. José Antonio Dias Toffoli.15 de junho de 2007.

${ }^{528}$ BRASIL. Ministério de Estado das Comunicações. Garantia No 11: Telecomunicações, Tecnologia da Informação.Hélio Costa. 29 de maio de 2007.

$\begin{array}{lllll}529 & \text { FIFA. } & \text { Fifa } & \text { Media } & \text { Releases. }\end{array}$ http://www.fifa.com/worldcup/organisation/media/medialist.html. Acesso em 10/9/2013.

${ }^{530}$ BRASIL. Exposições de Motivos N ${ }^{\circ}$ 15. 16 de Setembro de 2011. Subchefia de Assuntos Parlamentares. Assinado por: Ministro do Estado do Esporte, Orlando Silva de Jesus Júnior; Ministro do Estado das Relações Exteriores, Antonio de Aguiar Patriota; Ministro do Estado do Trabalho (interino) Paulo Roberto dos Santos Pinto; Ministro do Estado da Justiça, José Eduardo Martins Cardozo;Ministro do Estado da 
Há novamente a explícita declaração de que a iniciativa legislativa dá-se pelo encaminhamento do Formulário de Garantias assinado pelo governo brasileiro, o Form of Hosting Agreement da FIFA. Mesmo não existindo nenhuma negociação, mas apenas uma assinatura unilateral brasileira previamente definida, escrita e requisitada pela FIFA por meio da CBF, entidade que formulou o pedido de Bid ou postulação a sediar a Copa. Os Ministros de Estado que assinaram os termos não tinham, em princípio, competência delegada para firmar um ato internacional ${ }^{531}$.

Não é demasiado repetir que não houve negociação, pois nenhum diplomata brasileiro, parlamentar, ou até mesmo entidade foi capaz de negociar. Os documentos foram apenas solicitados e atendidos. No Formulário de Garantias não há nenhuma contrapartida da FIFA, apenas uma longa série de responsabilidades do governo brasileiro, de forma material e legal, não apenas com a FIFA, mas com todas as empresas patrocinadoras do evento. Legalmente, a FIFA pode, por exemplo, não realizar as competições, caso assim queira, sem sofrer qualquer tipo de sanção. Todas as indenizações são responsabilidade do Estado brasileiro.

Mesmo assim, o Formulário de Garantias foi encaminhado ao Congresso Nacional como Projeto de Lei N. 2.330/2011 na Câmara de Deputados. A tabela abaixo foi desenhada a partir de uma análise comparativa dos conteúdos dos 46 artigos do Projeto inicial e as onze garantias solicitadas pela FIFA.

Fazenda, Guido Mantega; Ministro do Estado do Desenvolvimento, Indústria e Comércio Exterior, Fernando Damata Pimentel; Ministro do Estado das Comunicações, Paulo Bernardo Silva; Ministra do Estado da Cultura, Anna Maria Buarque de Hollanda; Advogado-Geral da União, Luis Inacio Lucena Adams; Ministra do Estado do Planejamento, Orçamento e Gestão, Miriam Aparecida Belchior.

531 Qualquer autoridade pode assinar um ato internacional, desde que possua Carta de Plenos Poderes, firmada pelo Presidente da República e referendada pelo Ministro das Relações Exteriores. Segundo o artigo $7^{\circ}$ da Convenção de Viena sobre o Direito dos Tratados, a adoção ou autenticação de texto de tratado, bem como a expressão de consentimento a obrigar-se por meio dele, deve ser efetuada por pessoa detentora de plenos poderes. Exclui-se de tal regra para os tratados em geral, os Chefes de Estado, Chefes de Governo (por competência constitucional) e os Ministros das Relações Exteriores (por competência legal). Portanto, a capacidade de outros Ministros ou qualquer outra autoridade assinarem atos internacionais deriva de plenos poderes específicos para cada caso dados pelo Presidente da República. BRASIL. Ministério das Relações Exteriores. Atos Internacionais. http://dai-mre.serpro.gov.br/clientes/dai/dai/apresentacao/tramitacao-dosatos-internacionais, Contudo, segundo a Constituição Federal, no Art. 87, os Ministros de Estado serão escolhidos dentre brasileiros maiores de vinte e um anos e no exercício dos direitos políticos. Parágrafo único. Compete ao Ministro de Estado, além de outras atribuições estabelecidas nesta Constituição e na lei: I - exercer a orientação, coordenação e supervisão dos órgãos e entidades da administração federal na área de sua competência e referendar os atos e decretos assinados pelo Presidente da República; II - expedir instruções para a execução das leis, decretos e regulamentos; III - apresentar ao Presidente da República relatório anual de sua gestão no Ministério; IV - praticar os atos pertinentes às atribuições que lhe forem outorgadas ou delegadas pelo Presidente da República. BRASIL. CONSTITUIÇÃO FEDERAL. 1988. 


\begin{tabular}{|c|c|c|}
\hline Seções e Títulos & Artigos & $\begin{array}{c}\text { Formulário de Garantias/ } \\
\text { Form of Hosting Agreement }\end{array}$ \\
\hline \multicolumn{3}{|c|}{ Capítulo I Disposições Gerais } \\
\hline \multirow{2}{*}{$\begin{array}{c}\text { Disposições Gerais } \\
\text { Definições }\end{array}$} & 1 & \multirow[b]{2}{*}{ Caderno de Encargos da FIFA } \\
\hline & 2 & \\
\hline \multicolumn{3}{|c|}{ Capítulo II Da Proteção e Exploração de Direitos Comerciais } \\
\hline \multirow{8}{*}{$\begin{array}{c}\text { Seção I } \\
\text { Da Proteção Especial aos Direitos de } \\
\text { Propriedade Industrial } \\
\text { Relacionados aos Eventos }\end{array}$} & 3 & Garantias 8: iii, v \\
\hline & 4 & \multirow{7}{*}{$\begin{array}{c}\text { Garantias 8: vi, vii, viii, ix, xiv e } \\
\text { Parágrafos }\end{array}$} \\
\hline & 5 & \\
\hline & 6 & \\
\hline & 7 & \\
\hline & 8 & \\
\hline & 9 & \\
\hline & 10 & \\
\hline $\begin{array}{c}\text { Seção II } \\
\text { Das Áreas de Restrição Comercial e Vias } \\
\text { de Acesso }\end{array}$ & 11 & Garantia 8: xii \\
\hline \multirow{4}{*}{$\begin{array}{l}\text { Seção III Da Captação de Imagens ou } \\
\text { Sons, Radiodifusão e Acesso aos } \\
\text { Locais Oficiais de Competição }\end{array}$} & 12 & \multirow{4}{*}{$\begin{array}{c}\text { Garantias } 8 \text { e Parágrafos } \\
\text { Garantias } 11 \text { caput e Parágrafos }\end{array}$} \\
\hline & 13 & \\
\hline & 14 & \\
\hline & 15 & \\
\hline \multirow{2}{*}{$\begin{array}{l}\text { Seção IV crimes relacionados a eventos } \\
\text { Utilização indevida de Símbolos Oficiais }\end{array}$} & 16 & \multirow{2}{*}{ Garantia 8: iii } \\
\hline & 17 & \\
\hline Marketing de Emboscada por Associação & 18 & Garantia 8: i \\
\hline \multirow{4}{*}{ Marketing de Emboscada por Intrusão } & 19 & \multirow{4}{*}{ Garantia n. ${ }^{\circ} 8$ ii } \\
\hline & 20 & \\
\hline & 21 & \\
\hline & 22 & \\
\hline \multirow[t]{3}{*}{ Seção IV Das Sanções Civis } & 23 & \multirow{3}{*}{ Garantia 8: xvi, xii, $x, x i$} \\
\hline & 24 & \\
\hline & 25 & \\
\hline \multicolumn{3}{|c|}{ Capítulo III DOS VISTOS E DA ENTRADA DE TRABALHO } \\
\hline \multirow{3}{*}{ Vistos e da Entrada de Trabalho } & 26 & \multirow{3}{*}{ Garantia 1 e Garantia 2} \\
\hline & 27 & \\
\hline & 28 & \\
\hline \multicolumn{3}{|c|}{ Capítulo IV DA RESPONSABILIDADE CIVIL } \\
\hline & 29 & \multirow[b]{2}{*}{ Garantia 10 e Garantia 5} \\
\hline Seção I Da Responsabilidade da União & 30 & \\
\hline Seção II Do Seguro & 31 & Sem correspondência \\
\hline \multicolumn{3}{|c|}{ Capítulo V DA VENDA DOS INGRESSOS } \\
\hline \multirow{2}{*}{ Ingressos } & 32 & \multirow{2}{*}{ Garantia 8: x, xi } \\
\hline & 33 & \\
\hline
\end{tabular}




\begin{tabular}{|c|c|c|}
\hline & 34 & \\
\hline \multicolumn{2}{|c|}{ Capítulo VI DISPOSIÇÕES FINAIS } \\
\hline Responsabilidade da União & 35 & Garantia 10 \\
\hline Responsabilidade da União & 37 & Garantia 10 \\
\hline Isenção Custas Processuais & 38 & Garantia 5 \\
\hline Estádios & 39 & Garantia 10 \\
\hline $\begin{array}{c}\text { Segurança, Saúde, Vigilância sanitária, } \\
\text { alfândega e imigração }\end{array}$ & 40 & Sem correspondência \\
\hline Feriados & 41 & Sem correspondência \\
\hline Ref. às Leis 9.609, 9.610, 9.279 & 42 & Sem correspondência \\
\hline Ref. à Lei 10.671 & 43 & Sem correspondência \\
\hline Ref. à Lei 10.671 & 44 & Sem correspondência \\
\hline Ref. à Lei 9.615 & 45 & Sem correspondência \\
\hline Encaminhamento Legislativo & 46 & \\
\hline
\end{tabular}

Dos 46 artigos encaminhados, apenas sete não correspondem diretamente às Garantias da FIFA ou ao Caderno de Encargos. As correspondências são ipsis litteris as exigências do Form de Hosting Agreement (Formulário de Garantias), necessário para a candidatura do país a sede da Copa do Mundo. As garantias exigidas pela FIFA correspondem a 85\% do Projeto de Lei encaminhado pela Presidência da República ${ }^{532}$.

Esses dados são uma evidência do equivalente funcional de iniciativa legislativa que a ordem transnacional da FIFA foi capaz de estruturar no processo legislativo brasileiro. Essa iniciativa legislativa, e subsequente equivalente funcional, não é escondida pelo Brasil, como já foi demonstrado em diversas declarações explícitas do governo e dos parlamentares de que o Projeto de Lei atende aos compromissos e interesses da FIFA. Dessa forma, fica demonstrado o entrelaçamento legislativo. Contudo, para que o Formulário de Garantias se torne lei, é necessário ser debatido e votado.

Para tanto, todas as garantias têm certos padrões que asseguram suas intenções. Esses padrões estão definidos para todas as onze garantias, que contêm a seguinte declaração:

Afirmamos que o Governo Nacional aprovará (ou solicitará que o
Congresso, autoridades estaduais ou locais aprovem) todas as leis,
portarias, decretos e outros regulamentos especiais necessários ao
cumprimento desta Garantia, que serão promulgadas e executadas com a
maior brevidade possível, e que esta Garantia é e permanecerá
obrigatória, válida executável contra o Brasil e seu governo, bem como
todas as autoridades estaduais e locais, desde a data desta Garantia até 31

532 As Garantias que não foram incluídas no Projeto 2330/2001, respectivamente a Garantia No 3: Direitos Alfandegários e Impostos e a Garantia $\mathrm{N}^{\mathrm{o}}$ 4: Isenção Geral de Impostos foram incluídas na Lei Complementar n. ${ }^{\circ}$ 12.350/2010 que trata exclusivamente da isenção tributária para tudo que envolva a FIFA e seus parceiros. 
de dezembro de 2014, independente de qualquer mudança no governo do Brasil ou em seus representantes, ou qualquer mudança nas leis e regulamentos do Brasil.

a) Quanto ao trecho:

“aprovará (ou solicitará que o Congresso, autoridades estaduais ou locais aprovem) todas as leis, portarias, decretos e outros regulamentos especiais necessários ao cumprimento desta Garantia".

Tal afirmação evidencia a força de iniciativa que as garantias solicitadas pela FIFA, por meio de um de seus membros associados, a CBF, exercem perante ao governo nacional. Além das garantias que são encaminhadas em Projeto de Lei, o governo torna-se garantidor de modificações num amplo espectro de legislações: leis, portarias, decretos e outros regulamentos.

O equivalente funcional do processo legislativo sob tal perspectiva tem tamanha força que se sobrepõe à proposta transconstitucional, pois há uma ingerência desproporcional de uma organização privada, ilegítima, dentro de uma ordem constitucional. Esses casos são conhecidos dentro da teoria sistêmica de corrupção de sistemas, em que os acoplamentos estruturais deixam de aprender uns com os outros. Pela força exagerada de um dos sistemas, nesse caso a FIFA, uma instituição que poderia representar uma regulação para o esporte torna-se uma instituição que representa seus próprios interesses, econômicos, causando uma corrupção sistêmica $^{533}$.

De fato, não há nenhuma prova de que os interesses sejam exclusivos da FIFA; ao contrário, há evidências de que seus patrocinadores sejam fontes motivadoras de seu comportamento. Esse problema se agrava quando nos deparamos com ilegalidades avalizadas pelas Garantias.

b) Quanto ao trecho:

“esta Garantia é e permanecerá obrigatória, válida e executável contra o Brasil e seu governo, bem como todas as autoridades estaduais e locais (...) independente de qualquer mudança no governo do Brasil ou em seus representantes, ou qualquer mudança nas leis e regulamentos do Brasil”"

\footnotetext{
533 "Dá-se a corrupção sistêmica se houver incapacidade do sistema político de reagir, conforme seus próprios critérios e programas, à sobreposição negativa da economia.” NEVES, Marcelo. Transconstitucionalismo. São Paulo: Martins Fontes, 2009. p. 37.
} 
O direito administrativo é o direito público por excelência ${ }^{534}$. Nessa dogmática, o princípio da legalidade e da restrição do agente público a realizar somente atos que estejam previamente definidos apresenta-se como necessário à própria noção de Estado de Direito. Dessa forma, torna-se gritante o fato de Ministros do governo emitirem um "título obrigatório, válido e executável” contra o Brasil, em todos os seus níveis.

Essa questão ficou evidenciada nos debates no Plenário da Câmara, quando a base aliada precisava se expor e explicar as excepcionalidades do Projeto de Lei:

Agora, por que nós estamos votando esta matéria? Qual é o sentido dela? Por que essa excepcionalidade? Não é para rebaixar o debate em relação à problemática do uso do álcool.Todos nós sabemos que faz mal para a saúde. Todos nós sabemos que faz mal à saúde. Trata-se, na verdade, de uma excepcionalidade. Quero me dirigir ao povo brasileiro dizendo-lhe que o Presidente Lula tomou uma decisão monocrática e disse à FIFA "eu quero" (...) Mas não é disso que se trata neste momento. O importante é que o Brasil vai cumprir o acordo, vai cumprir esse tratado. Nós queremos a Copa do Mundo aqui. Foi feito um acordo com a FIFA, assinado pelo Presidente Lula, e a Presidente Dilma vai honrá-lo. Se há algo que este Governo faz é honrar seus compromissos, é assumir compromissos e honrá-los. E se tem algo que vamos fazer aqui hoje é votar esse acordo e essas garantias dadas à FIFA. É uma excepcionalidade! É um período curto - um período curto - e é uma exigência! Agora, isso não tem nada a ver com soberania! $!^{535}$

Com esses dados, concluímos que é possível afirmar que há um equivalente funcional e, portanto, uma iniciativa legislativa transnacional. Embora sem poderes previstos pela Constituição do Brasil, mas por meio de sua capacidade de convencimento e competência política, a FIFA obteve o poder de legislar no Congresso Nacional.

Entende-se que pela falta de previsão constitucional nacional para uma iniciativa legislativa transnacional, pelo déficit democrático da FIFA, pelos traços de exceção jurídica na legislação nacional, esse entrelaçamento legislativo tem caráter de corrupção sistêmica.

Como será observado, as exceções são de variadas ordens. Sua denúncia e debate ocorreram no Congresso Nacional, por meio da Comissão Especial da Câmara, do Plenário e do Senado.

\footnotetext{
${ }^{534}$ MELLO, Celso Antônio Bandeira. Curso de Direito Administrativo - 29a Ed. Malheiros: São Paulo, 2012.

${ }^{535}$ BRASIL. CAMARA DOS DEPUTADOS. Detaq - Discursos e Notas Taquigráficas. JILMAR TATTO (PT-SP). Data: 28/03/2012. Sessão: 059.2.54.0 Brasília.
} 


\subsubsection{Debate e aprovação Legislativa}

Sr. Presidente, meus caros colegas do Congresso Nacional brasileiro, nós estamos diante de uma decisão da maior importância. Este é o momento de dizer se o Congresso Nacional brasileiro está ou não de cócoras para a FIFA e para os patrocinadores da Copa do Mundo. ${ }^{536}$

Após ser encaminhado como Projeto de Lei N. 2.330/2011, o Formulário de Garantias da FIFA foi tema de debates pela diplomacia parlamentar. Pela multiplicidade de temas, foi criada a Comissão Especial destinada a proferir parecer sobre o Projeto de Lei. As Comissões Especiais são constituídas quando as proposições legislativas versam sobre a matéria de competência de mais de três Comissões ${ }^{537}$. O Projeto de Lei 2330/2001 previa parecer das seguintes Comissões: Ciência e Tecnologia, Comunicação e Informática; Relações Exteriores e de Defesa Nacional; Desenvolvimento Econômico, Indústria e Comércio; Defesa do Consumidor; Turismo e Desporto; Finanças e Tributação e Constituição e Justiça e de Cidadania. Em consequência, foi criada a Comissão Especial para a Lei Geral da Copa.

O Deputado Relator Vicente Cândido (PT/SP) emitiu parecer favorável "pela constitucionalidade, juridicidade e técnica legislativa; pela não implicação da matéria com aumento ou diminuição da receita ou das despesas públicas, não cabendo pronunciamento quanto à adequação financeira e orçamentária; e, no mérito, pela aprovação deste e do PL 2686/2011, apensado com substitutivo ${ }^{538}$."

Com espaço reduzido às Comissões e ao Plenário, o debate parlamentar foi restrito ao nível de detalhamento dos compromissos assumidos pelo Brasil e limitação do poder legislativo da FIFA. A sua rejeição total nunca foi levantada pela situação ou oposição.

No Plenário da Câmara, foram apresentadas 66 emendas, sendo aprovadas as de número $3,4,6,7,10,21,27,28,35,36,37,38,42,51$ e 63 e rejeitadas as demais na forma da Subemenda Substitutiva Global apresentada à Mesa. Conforme tabela 1 em anexo, pode-se observar individualmente todos os temas das 66 emendas propostas no Plenário da Câmara. O plenário aprovou o texto final no dia 28/03/2012, que foi encaminhado ao Senado Federal.

\footnotetext{
${ }^{536}$ BRASIL. CAMARA DOS DEPUTADOS. Detaq - Discursos e Notas Taquigráficas. Debate do Plenário. VANDERLEI MACRIS (PSDB-SP) Data: 28/03/2012. Sessão: 059.2.54.0. Brasília.

${ }^{537}$ BRASIL. CÂMARA DOS DEPUTADOS. Regimento Interno. Art. 34. As Comissões Especiais serão constituídas para dar parecer sobre: II - proposições que versarem matéria de competência de mais de três Comissões que devam pronunciar-se quanto ao mérito, por iniciativa do Presidente da Câmara, ou a requerimento de Líder ou de Presidente de Comissão interessada.

${ }^{538}$ BRASIL. CÃMARA DOS DEPUTADOS. Comissão Especial Destinada a Proferir parecer ao Projeto de Lei N. 2.330/2011. Relatório. Relator: Deputado Vicente Cândido.
} 
No Senado, o texto tramitou como Projeto de Lei da Câmara No 10 DE 2012. Tramitando nas seguintes Comissões: CE - Comissão de Educação, Cultura e Esporte; CMA Comissão de Meio Ambiente, Defesa do Consumidor e Fiscalização e Controle; CAE Comissão de Assuntos Econômicos CCJ - Comissão de Constituição, Justiça e Cidadania. Destaco a Comissão de Educação, que submeteu sete Emendas, todas reprovadas. No plenário, foram apresentadas 38 emendas, sendo aprovadas, em globo, apenas as seguintes: números 1, 2, 3, 4 e 22. No dia 9 de maio de 2012 foi aprovado o texto e enviado para sanção da Presidente da República.

Por sua vez, a Presidente da República Dilma Rousseff vetou os seguintes artigos: art. $\S 3^{\circ}$ do art. 26 (cota de ingressos), arts. 59 e 60 (serviço voluntário), $\S 9^{\circ}$ do art. 26 (desconto em ingressos), arts. 48 e 49 (vistos a estrangeiros) no dia 5 de junho de 2012. Não obstante, o projeto torna-se a Lei Geral da Copa, Lei n. ${ }^{\circ} 12.663 / 2012$, publicado no DOU de 6.6.2012 e retificado em 8.6.2012.

Dentro desse panorama de trâmite legislativo, cabe destacar os principais pontos de debate que ficaram evidenciados nas análises das garantias individualmente. Observando-se comparativamente cada dispositivo, agrava-se e comprova-se o nível de interferência legislativa, não apenas modificando leis, mas também suspendendo direitos durante os eventos, o que foi denunciado pelos deputados.

A Garantia n. ${ }^{\circ} 2$ - Permissões de Trabalho tem o objetivo de permitir um padrão de normas e regras trabalhistas conforme a FIFA. Dessa forma, os artigos 19 a 21 do capítulo três da Lei Geral da Copa, que trata de "Dos Vistos e Entrada de Trabalho", estão subordinados a essa garantia, que tem como destaque a suspensão de toda a legislação trabalhista, existente como limitações nas horas de trabalho ou uso de mão de obra nãosindicalizada, até o dia 31 de dezembro de 2014, em relação às Competições (Copa das Confederações e do Mundo). De acordo com a garantia n. 2:

Garantimos ainda que a aplicabilidade de qualquer legislação trabalhista existente (como limitações nas horas de trabalho ou uso de mão de obra não-sindicalizada) que possa restringir qualquer um dos indivíduos acima de desempenhar integralmente suas atribuições ou atividades relacionadas às Competições será suspensa (com relação aos indivíduos acima mencionados) por um período iniciando-se na data desta Garantia de Governo e encerrando-se em 31 de dezembro de $2014^{539}$ (grifo nosso).

\footnotetext{
${ }^{539}$ BRASIL. Ministério de Estado do Trabalho e Emprego. Garantia №2: Permissões de Trabalho. Ministro Ronaldo Lessa (interino). Carta No 287 / GM. 14 de junho de 2007.
} 
Consequentemente, essa garantia e equivalente proposta legislativa geraram manifestações de tensão sobre os direitos trabalhistas ${ }^{540}$. A questão trabalhista, da exclusividade da FIFA e direitos humanos foram focos dados aos debates sobre o tema.

A emenda n. 53 solicitava regular o trabalho voluntário da FIFA e, em caso de abusos, solicitava a garantia de sua remuneração ${ }^{541}$. A emenda n. 29, do Deputado Vicentinho (PT/SP), solicitava a erradicação de trabalho escravo e infantil a todas empresas prestadoras de serviço que estivessem vinculada à FIFA e às Competições. A emenda n. ${ }^{\circ} 30$ tinha objetivo de garantir e regular o livre exercício profissional dos vendedores autônomos e ambulantes $^{542}$. Todas as emendas foram reprovadas.

Outro destaque é a exclusividade dada à FIFA e seus parceiros para venda de produtos. Com respeito a isso, pronunciaram-se os deputados do PSOL, na justificativa de emenda parlamentar n. 54, que pretendia barrar essa emenda:

Pensemos em um grande evento mundial, como uma corrida de Fórmula 1,
ou o "Rock in Rio". É normal que exista uma área que seja destinada para
garantir a realização da corrida. Mas a F1 nunca exigiu o que está previsto
neste artigo 11, para garantir a exclusividade de seus patrocinadores. O
impacto desta medida, além da visível restrição ao direito do consumidor é
notado já nas operações de "higienização" e remoção para garantir a
"limpeza da área" e seu futuro uso para fins de especulação imobiliária. Ou
seja, trata-se mais uma vez de retirar e restringir o direito a cidade para o seu
povo. Os recursos são públicos. O futebol é do povo. O comércio brasileiro
tem que ter o direito de continuar funcionando normalmente durante a Copa
do Mundo, tal como sempre funcionou em outras Copas, e nas proximidades
dos locais de competição, desde que garantidos os requisitos de segurança,
tal como acontecem em vários outros grandes eventos no país ${ }^{543}$.

Essa emenda também foi reprovada.

As Garantia n. ${ }^{o} 3$ e 4: Isenção de Impostos alfandegários/ Isenção Geral de Impostos influenciaram o artigo 53 da Lei Geral da Copa, assim como deram carta branca para modificação de legislação tributária. Essa carta branca irá gerar uma Lei específica sobre

\footnotetext{
540 “Hoje foi publicada uma matéria de primeira página no Valor Econômico: de que a Lei Geral da Copa tem um artigo que proíbe o direito de greve dos trabalhadores da construção civil, da construção pesada. E isso criou uma apreensão no movimento sindical. Estão aqui, Sr. Presidente (Vicente Cândido), algumas centrais sindicais que vieram pedir o esclarecimento. E, como essa matéria foi feita pelo Presidente da CUT, quero, então, se for possível, um esclarecimento". BRASIL. CÂMARA DOS DEPUTADOS. Deputado Paulo Pereira da Silva Detaq - Discursos e Notas Taquigráficas. Sessão: 0032/12. Data: 28/02/2012.

${ }^{541}$ BRASIL. CÂMARA DOS DEPUTADOS. Projeto de Lei N. 2.330/2011. Emenda de Plenário N. 53. Ivan Valente (PSOL/RJ) Brasília. 28/03/2012. BRASIL.

${ }^{542}$ BRASIL. CÂMARA DOS DEPUTADOS. Projeto de Lei N. 2.330/2011. Emenda de Plenário N. 29. Vicentinho (PT/SP) Brasília. 28/03/2012. BRASIL. BRASIL. CÂMARA DOS DEPUTADOS. Projeto de Lei N. 2.330/2011. Emenda de Plenário N. 30. Vicentinho (PT/SP) Brasília. 28/03/2012.

${ }^{543}$ BRASIL. CÂMARA DOS DEPUTADOS. Projeto de Lei N. 2.330/2011. Emenda de Plenário N. 54. Ivan Valente (PSOL/RJ) Brasília. 28/03/2012. BRASIL.
} 
medidas tributárias para as Competições, a Lei n. ${ }^{\circ}$ 12.350/2010. Destacamos, nas Garantias, o trecho:

\begin{abstract}
A FIFA tem o direito de exigir do Brasil que providencia uma emenda desta Garantia do Governo de forma a levar em conta regulamentos tributários ou circunstâncias específicas no Brasil, mudanças substanciais nas regras tributárias ou legislação estrangeira ou internacional ou mudanças na estrutura tributária ou legal da FIFA ou das subsidiárias da FIFA.

Garantimos que nenhuma autoridade ou órgão federal, estadual, local ou outro imporá quaisquer impostos, diretos ou outras arrecadações direta ou indiretamente com relação à Copa das Confederações da FIFA - e/ou à Copa do Mundo FIFA - 2014 que não estiverem de acordo com as normas de tributação e sistemas aplicados aos países membros do OECD. ${ }^{544}$
\end{abstract}

Ao final das garantias mencionadas, o Brasil também se compromete a pagar indenização à FIFA e qualquer outra das subsidiárias que forem penalizadas a respeito da ordem tributária de qualquer dos órgãos estatais brasileiros. Sobre isso, pronunciaram-se também os deputados, em particular o Deputado Chico Alencar (PSOL/RJ):

Ainda assim, essa Lei Geral da Copa propriamente tem os seus problemas, não apenas esses da liberação da bebida para especificamente esses jogos ou atribuir aos Estados essa suposta autoridade, ferindo o Estatuto do Torcedor. Ela estabelece, por exemplo, um privilégio para os produtos da FIFA, que serão mais de mil, que nenhum produto brasileiro tem, com isenções totais até o fim de 2014. Isso é um perfeito absurdo! $!^{545}$

Essas modificações legislativas representadas por exceções tributárias motivaram duas "ADIs" - Ações Diretas de Inconstitucionalidade diferentes do Procurador Geral da República, sendo que a primeira trata especificamente da Lei Geral da Copa e questiona o art. 53 ( também os arts. 23, 37 a 47$)^{546}$.

${ }^{544}$ BRASIL. Ministério de Estado da Fazenda. Garantia No 3: Direitos Alfandegários e Impostos. Ministro Guido Mantega. Junho de 2007 (sem referência ao dia); BRASIL. Ministério de Estado da Fazenda. Garantia N 4: Isenção Geral de Impostos. Ministro Guido Mantega. Junho de 2007 (sem referência ao dia).

545 BRASIL. DIÁRIO DA CAMARA DOS DEPUTADOS. Deputado CHICO ALENCAR (PSOL-RJ). Data: 28/03/2012.

546 "Trata-se de ação direta de inconstitucionalidade, com pedido de medida cautelar, proposta pelo Procurador-Geral da República, em que se questiona os arts. 23, 37 a 47 e 53 da Lei 12.663, de 5/6/2012, que dispõe sobre as medidas relativas à Copa das Confederações FIFA 2013, à Copa do Mundo FIFA 2014 e à Jornada Mundial da Juventude - 2013, a serem realizadas no Brasil. Destaco o teor dos dispositivos impugnados, verbis: “Art. 23. A União assumirá os efeitos da responsabilidade civil perante a FIFA, seus representantes legais, empregados ou consultores por todo e qualquer dano resultante ou que tenha surgido em função de qualquer incidente ou acidente de segurança relacionado aos Eventos, exceto se e na medida em que a FIFA ou a vítima houver concorrido para a ocorrência do dano. Parágrafo único. A União ficará sub-rogada em todos os direitos decorrentes dos pagamentos efetuados contra aqueles que, por ato ou omissão, tenham causado os danos ou tenham para eles concorrido, devendo o beneficiário fornecer os meios necessários ao exercício desses direitos. (...) Art. 37. É concedido aos jogadores, titulares ou reservas das 
A outra ADI trata especialmente da Lei n. ${ }^{\circ} 12.350^{547}$. A primeira ADI também questionou o art. 23, que responsabiliza o Estado brasileiro, fundado na Garantia n. ${ }^{\circ} 5$ dada à FIFA. Ambas ainda não foram julgadas.

A Garantia n. ${ }^{\circ} 5$ relativa a Segurança e Proteção foi alocada nos artigos 23 e 55 da Lei Geral da Copa. Além das garantias mais comuns frente a grande eventos, chama a atenção novamente a responsabilidade assumida pelo governo no que se refere a indenizações e imunidade do Organizador do Evento, FIFA, CBF e COL. De acordo com a Garantia n. 5:

\begin{abstract}
Aceitamos total responsabilidade por quaisquer incidentes de segurança e/ou proteção e/ou acidentes correlatos relacionado às Competições e indenizamos, defendemos e mantemos imune a FIFA e todas as subsidiárias da FIFA por e contra todas as responsabilidades, obrigações, danos, perdas, reivindicações, demandas, recuperações, deficiências, custos ou despesas (incluindo honorários advocatícios) que essas partes possam sofrer ou incorrer com relação a, resultantes de ou oriundos de quaisquer
\end{abstract}

seleções brasileiras campeãs das copas mundiais masculinas da FIFA nos anos de 1958, 1962 e 1970: I prêmio em dinheiro; e II - auxílio especial mensal para jogadores sem recursos ou com recursos limitados. Art. 38. O prêmio será pago, uma única vez, no valor fixo de $\mathrm{R} \$ 100.000,00$ (cem mil reais) ao jogador. Art. 39. Na ocorrência de óbito do jogador, os sucessores previstos na lei civil, indicados em alvará judicial expedido a requerimento dos interessados, independentemente de inventário ou arrolamento, poder-se-ão habilitar para receber os valores proporcionais a sua cota-parte. Art. 40. Compete ao Ministério do Esporte proceder ao pagamento do prêmio. Art. 41. O prêmio de que trata esta Lei não é sujeito ao pagamento de Imposto de Renda ou contribuição previdenciária. Art. 42. O auxílio especial mensal será pago para completar a renda mensal do beneficiário até que seja atingido o valor máximo do salário de benefício do Regime Geral de Previdência Social. Parágrafo único. Para fins do disposto no caput, considera-se renda mensal 1/12 (um doze avos) do valor total de rendimentos tributáveis, sujeitos a tributação exclusiva ou definitiva, não tributáveis e isentos informados na respectiva Declaração de Ajuste Anual do Imposto sobre a Renda da Pessoa Física. Art. 43. O auxílio especial mensal também será pago à esposa ou companheira e aos filhos menores de 21 (vinte um) anos ou inválidos do beneficiário falecido, desde que a invalidez seja anterior à data em que completaram 21 (vinte um) anos. § 1o Havendo mais de um beneficiário, o valor limite de auxílio per capita será o constante do art. 42 desta Lei, dividido pelo número de beneficiários, efetivos, ou apenas potenciais devido à renda, considerando-se a renda do núcleo familiar para cumprimento do limite de que trata o citado artigo. § 2o Não será revertida aos demais a parte do dependente cujo direito ao auxílio cessar. Art. 44. Compete ao Instituto Nacional do Seguro Social (INSS) administrar os requerimentos e os pagamentos do auxílio especial mensal. Parágrafo único. Compete ao Ministério do Esporte informar ao INSS a relação de jogadores de que trata o art. 37 desta Lei. Art. 45. O pagamento do auxílio especial mensal retroagirá à data em que, atendidos os requisitos, tenha sido protocolado requerimento no INSS. Art. 46. O auxílio especial mensal sujeita-se à incidência de Imposto sobre a Renda, nos termos da legislação específica, mas não é sujeito ao pagamento de contribuição previdenciária. Art. 47. As despesas decorrentes desta Lei correrão à conta do Tesouro Nacional. (...) Art. 53. A FIFA, as Subsidiárias FIFA no Brasil, seus representantes legais, consultores e empregados são isentos do adiantamento de custas, emolumentos, caução, honorários periciais e quaisquer outras despesas devidas aos órgãos da Justiça Federal, da Justiça do Trabalho, da Justiça Militar da União, da Justiça Eleitoral e da Justiça do Distrito Federal e Territórios, em qualquer instância, e aos tribunais superiores, assim como não serão condenados em custas e despesas processuais, salvo comprovada má-fé”. O requerente sustenta, em síntese, que os dispositivos questionados afrontam os arts. $5^{\circ}$, caput, 19 , III, 37 , caput e $\S 6^{\circ}, 150$, II e 195 , $\S 5^{\circ}$, todos da Constituição Federal.” BRASIL. ADI 4976. Despacho Ministro RICARDO LEWANDOWSKI - Relator, julgado em 18/06/2013, publicado em PROCESSO ELETRÔNICO DJe-119 21/06/2013. Brasília, 18 de junho de 2013.

${ }^{547}$ Art. 23, capítulo IX, Ver também: Instrução Normativa $n^{\circ} 1.293$, de 21 de setembro de 2012 - Dispõe sobre o despacho aduaneiro de bens procedentes do exterior destinados à utilização na Copa das Confederações FIFA 2013 e na Copa do Mundo FIFA 2014, de que trata esta Lei. 
incidentes e/ou acidentes de segurança e/ou proteção com relação às Competições. ${ }^{548}$

As emendas do Plenário da Câmara n. ${ }^{\circ} 56$ e n..$^{\circ} 8$ tentaram obstruir a Responsabilidade Civil da União, descrita no Capítulo IV e, portanto, os artigos 22, 23 e 24 do Substitutivo aprovado na Comissão Especial ${ }^{549}$. Contudo, ambas as emendas foram reprovadas.

Dentre as emendas aprovadas, destaca-se a do Deputado Vicentinho (PT/SP), que propôs emenda n. $^{\circ}$ 27, visando garantir o direito constitucional à manifestação e a liberdade de expressão. Assim, foi adicionado o parágrafo primeiro ao art. 28: "§ $1^{\circ}$ É ressalvado o direito constitucional ao livre exercício de manifestação e à plena liberdade de expressão em defesa da dignidade da pessoa humana." 550

De outro modo, um novo projeto de lei, que teve iniciativa no Senado, o PLS 728/2011, de autoria dos Senadores Walter Pinheiro (PT-BA), Ana Amélia (PP-RS) e Marcelo Crivela (PRB-RJ), cria uma série de tipos penais exclusivos para os eventos FIFA ${ }^{551}$. O projeto tem sido chamado de AI-5 da Copa e pretende, dentre outras coisas, proibir greves e tipificar o terrorismo. As penas são bastante duras. Por exemplo, o terrorismo, ambiciosamente definido pela Lei como "o ato de provocar terror ou pânico generalizado mediante ofensa à integridade física ou privação da liberdade de pessoa, por motivo ideológico, religioso, político ou de preconceito racial, étnico ou xenófobo", tem a pena de no mínimo 15 e no máximo 30 anos de reclusão ${ }^{552}$.

A Comissão de Direitos Humanos da OAB de São Paulo considerou o projeto um atentado contra o Estado Democrático de Direito: "É um projeto de lei absurdo que quer sobrepor os interesses de mercado à soberania popular. Uma lei para proteger a FIFA e não os cidadãos e que, além de tudo, abre precedentes para injustiças por suas definições vagas." "553 O projeto permanece tramitando no Senado e deverá ser votado no início de 2014.

\footnotetext{
${ }^{548}$ BRASIL. Ministério de Estado de Justiça. Garantia No 5: Segurança e Proteção. Ministro Tarso Genro.29 de maio de 2007.

${ }^{549}$ BRASIL. CÂMARA DOS DEPUTADOS. Projeto de Lei N. 2.330/2011. Emenda de Plenário N. 8. André Fiqueiredo (PDT/CE) Brasília. 28/03/2012. BRASIL. CÂMARA DOS DEPUTADOS. Projeto de Lei N. 2.330/2011. Emenda de Plenário N. 56. Deputado Ivan Valente (PSOL/SP) Brasília. 28/03/2012.

550 BRASIL. CÂMARA DOS DEPUTADOS. Projeto de Lei N. 2.330/2011. Emenda de Plenário N. 27. Vicentinho (PT/SP) Brasília. 28/03/2012.

551 "Define crimes e infrações administrativas com vistas a incrementar a segurança da Copa das Confederações FIFA de 2013 e da Copa do Mundo de Futebol de 2014, além de prever o incidente de celeridade processual e medidas cautelares específicas, bem como disciplinar o direito de greve no período que antecede e durante a realização dos eventos, entre outras providências." In: BRASIL. SENADO FEDERAL. Projeto de Lei do Senado N. ${ }^{\circ}$ 728/2011. Brasília.

${ }^{552}$ BRASIL. SENADO FEDERAL. Projeto de Lei do Senado N. ${ }^{\circ}$ 728/2011. Brasília. Art. $4^{\circ}$.

${ }^{553}$ DIP, Andrea. Projeto de lei quer punir 'terroristas' e grevistas durante a Copa. Carta Capital.
} 
A Garantia n. 8 Proteção e Exploração de Direitos Comerciais certamente foi o item mais longo e controverso da Lei Geral da Copa, e se refere a garantia alusiva aos direitos comerciais das Competições. Comprova essa afirmação o fato de vinte e três artigos do texto final aprovado da Lei Geral da Copa serem dedicados a essa garantia, a saber: art. 3 - 18; art. 30 - 34; art. 55. Dentre os aspectos mais importantes da Lei destacam-se as bebidas alcoólicas, regime especial de licença de produtos e exclusividade territorial para Licenciados FIFA. De acordo com a garantia:

(xx) Confirmação de que o endosso, legislação ou suporte por parte dos governos/agências regionais, municipais e/ou locais para a medida acima mencionada sejam obtidos em tempo hábil.

Afirmamos e garantimos, ainda, à FIFA, que o governo nacional aprovará (ou solicitará que o Congresso, autoridades estaduais ou locais aprovem) dentro do que for necessário, leis especiais destinadas a assegurar a proteção da propriedade da FIFA de todos os Direitos de Mídia, Direitos de Marketing, marcas e outros direitos de propriedade intelectual e comercial e deverá proporcionar a FIFA o apoio de dirigentes de autoridades relevantes, como política e alfândega, para auxiliarem na proteção de Direitos de Mídia, Direitos de Marketing, marcas e outros direitos de propriedade intelectual e $\operatorname{comercial}^{554}$ (grifo nosso).

Os trechos acima em destaque demonstram o tom no qual a FIFA propõe legislativamente seus interesses e de seus parceiros. À revelia das legislações nacionais em vigência, por meio do Formulário de Garantias assinado, ela força os governos a se submeterem às suas necessidades, sustentando que esses direitos estariam contemplados pela garantia do governo, assinada apenas pelo Poder Executivo.

\begin{abstract}
Afirmamos e garantimos também à FIFA, e asseguraremos,que não existem nem existirão restrições legais ou proibições sobre a venda, publicidade ou distribuição de produtos das Afiliadas Comerciais, inclusive alimentos e bebidas, nos Estádios ou em outros locais durante as Competições e que não há nem haverá legais ou proibições sobre Direitos de Mídia, Direito de Marketing, marcas e outros direitos de propriedade intelectual e comercial. Concordamos que quaisquer leis ou regulamentos sobre mídia que interfiram ou colidam com a exploração pela FIFA dos Direitos de Mídia estão suspensos com respeito à competição e que a FIFA pode explorar os Direitos de Mídia sem restrições no Brasil da forma que escolher.
\end{abstract}

554 BRASIL. Ministério de Estado de Justiça, Ministério de Estado do Desenvolvimento, Indústria e Comércio Exterior, Ministério de Estado da Cultura, Ministério de Estado da Ciência e Tecnologia. Garantia N.8: Proteção e Exploração de Direitos Comerciais. Respectivamente: Tarso Genro, Miguel Jorge, João Luiz Silva Ferreira, Sergio Machado Rezende. 29 de maio de 2007. 
Garantimos que a FIFA e cada uma das entidades abaixo indicadas terão permissão incondicional de realizar atividades comerciais com relação às Competições no Brasil ${ }^{555}$.

Em especial, a venda de bebida alcoólica foi o debate mais polêmico em torno da Lei Geral da Copa. Foi o tema com maior número de emendas, no total, oito do plenário da Câmara dos Deputados e uma na Comissão de Educação do Senado. Todas foram reprovadas $^{556}$. Dessas, sete solicitaram explicitamente a proibição à comercialização de bebidas alcoólicas no interior dos estádios que sediarão as partidas das Competições ${ }^{557}$. O debate parlamentar foi intenso, como pode ser destacada a declaração do deputado Vanderlei Macris (PSDB/SP):

Pois bem, Sr. Presidente, quero dizer que, nessa discussão que fizemos na reunião de Lideranças, alguns partidos, como, por exemplo, o PSDB, o PSC, o PPS, já se comprometeram a assinar um pedido de destaque para o art. 29 do relatório da proposta de lei, que trata da venda e proibição de bebida alcoólica nos estádios. A manutenção do art. 29 libera a venda a bebida alcoólica. Nós queremos retirar e rejeitar essa liberação, para manter a legislação brasileira, que já proíbe a venda de bebida alcoólica nos estádios $^{558}$. (grifo nosso)

Além do intenso debate parlamentar, a autorização para venda de bebidas alcoólicas representa o exemplo importante de vários indícios da ordem transnacional. Primeiro, a forma de influência (no sentido de política stricto sensu) da ordem transnacional na modificação de

555 BRASIL. Ministério de Estado de Justiça, Ministério de Estado do Desenvolvimento, Indústria e Comércio Exterior, Ministério de Estado da Cultura, Ministério de Estado da Ciência e Tecnologia. Garantia N.8: Proteção e Exploração de Direitos Comerciais. Respectivamente: Tarso Genro, Miguel Jorge, João Luiz Silva Ferreira, Sergio Machado Rezende. 29 de maio de 2007.

${ }^{556}$ BRASIL. CÂMARA DOS DEPUTADOS. Projeto de Lei N. 2.330/2011. Emenda de Plenário N. 1. do Deputado Vanderlei Macris (PSDB/SP). Brasília. 28/03/2012. BRASIL. CÂMARA DOS DEPUTADOS. Projeto de Lei N. 2.330/2011. Emenda de Plenário N. 2. do Deputado Vanderlei Macris (PSDB/SP). Brasília. 28/03/2012. BRASIL. CÂMARA DOS DEPUTADOS. Projeto de Lei N. 2.330/2011. Emenda de Plenário N. 31. Deputado Onofre Santo Agostini (PSD/SC). Brasília. 28/03/2012.BRASIL. CÂMARA DOS DEPUTADOS. Projeto de Lei N. 2.330/2011. Emenda de Plenário N. 41. Deputado Marcelo Aguiar (PSD/SP) Frente Parlamentar Evangélica. Brasília. 28/03/2012.BRASIL. CÂMARA DOS DEPUTADOS. Projeto de Lei N. 2.330/2011. Emenda de Plenário N. 50. Deputados Chico Alencar (PSOL/RJ), Ivan Valente (PSOL/SP) e Jean Wyllis (PSOL/RJ). Brasília. 28/03/2012. BRASIL. CÂMARA DOS DEPUTADOS. Projeto de Lei N. 2.330/2011. Emenda de Plenário N. 15. Deputada Carmen Zanotto (PPS/SC). Brasília. 28/03/2012.

557 Outras duas propostas de emenda tocaram no assunto. O Deputado Paulo Pimenta (PT/RS), propôs a Vedação da Propaganda e Vanderlei Macris (PSDB/PE) uma regulação do teor alcoólico. "Consideram-se bebidas alcoólica, para todos os efeitos legais, bebidas potáveis que contenham em sua composição teor alcoólico igual ou superior a meio grau Gay-lussac.” In: BRASIL. CÂMARA DOS DEPUTADOS. Projeto de Lei N. 2.330/2011. Emenda de Plenário N. 66. Deputado Vanderlei Macris (PSDB/PE). Brasília. 28/03/2012. ;BRASIL. CÂMARA DOS DEPUTADOS. Projeto de Lei N. 2.330/2011. Emenda de Plenário N. 61. Deputado Paulo Pimenta (PT/RS). Brasília. 28/03/2012.

558 BRASIL. CAMARA DOS DEPUTADOS. Detaq - Discursos e Notas Taquigráficas. VANDERLEI MACRIS (PSDB-SP). Data: 28/03/2012. Sessão: 032.2.54.0. Brasília. 
uma lei nacional. Observa-se um debate acerca de um interesse econômico de um dos patrocinadores do evento travestido de questão de saúde pública: um interesse puramente privado em desfavor de um interesse público. Segundo, para aquisição de um equivalente funcional de força legislativa (uma vez que não tem "o poder" de legislar) a ordem transnacional se molda inversamente. Não foi a $A B$ Inbev (patrocinadora de bebidas) que solicitou ao Brasil uma alternação legislativa. Foi o Brasil que assinou uma garantia que prevê que não "existirão restrições legais ou proibições (...) inclusive alimentos e bebidas nos Estádios", uma vez que decidiu ter as competições.

A maioria dos deputados da oposição se mostraram contrários a proposição e se pronunciaram apontando diversos problemas sociais, jurídicos e políticos nessa norma. Por exemplo, a deputada Carmen Zanotto (PPS-SC) lembrou que o tema social proposto para Copa do Mundo se contradiz: "Por um mundo sem armas, sem drogas, sem violência e sem racismo" 559 . Contudo, a violência e as drogas estão associadas efetivamente ao consumo do álcool. "A própria CBF emitiu uma resolução em 2008 proibindo - e ela é assinada pelo Sr. Presidente Ricardo Teixeira - a venda e o consumo de bebidas alcoólicas nos campos de futebol" 560 .

Não somos contra a realização dos jogos da Copa do Mundo nem da Copa das Confederações, porém, senhoras e senhores, não podemos e não devemos, sob pena de a população brasileira não conseguir entender o porquê de o Estatuto do Torcedor, no art. 13-A, estar sendo liberado durante o período desses jogos... Por que estará sendo liberado? Porque o art. 13-A é muito claro quando diz portar ou consumir bebidas que possam gerar a violência ${ }^{561}$.

Como destacado pela Deputada, a venda de bebidas alcoólicas contraria frontalmente

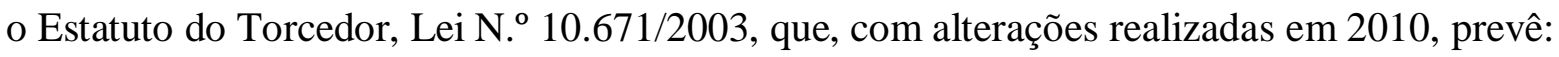

Art. 13-A. São condições de acesso e permanência do torcedor no recinto esportivo, sem prejuízo de outras condições previstas em lei:

II - não portar objetos, bebidas ou substâncias proibidas ou suscetíveis de gerar ou possibilitar a prática de atos de violência ${ }^{562}$.

A norma teve o objetivo de eliminar a bebida alcoólica dos estádios brasileiros em defesa dos espectadores, dos torcedores. Contudo, a proposta inicial do Projeto de Lei

\footnotetext{
${ }^{559}$ Art. 29, Inciso I, letra "a" da Lei Geral da Copa. Op. Cit.

${ }^{560}$ BRASIL. CÂMARA DOS DEPUTADOS. Detaq - Discursos e Notas Taquigráficas. Sessão: 0032/12. Data: 28/02/2012.

561 BRASIL. CAMARA DOS DEPUTADOS. Detaq - Discursos e Notas Taquigráficas. Deputada CARMEN ZANOTTO (PPS-SC). Data: 28/03/2012. Hora: 19:36. Sessão: 059.2.54.O. Brasília.

${ }^{562}$ BRASIL. ESTATUTO DO TORCEDOR. LEI 10.671/2003.
} 
2.3330/2001 previa, inclusive, a alteração do Estatuto do Torcedor, modificando a norma definitivamente, como declara o Deputado Vicente Cândido, relator do Projeto na Câmara: “O relatório (do Projeto Inicial) anterior vinha, no ano passado, com esse dispositivo, alterando o Estatuto do Torcedor. Em sentindo aqui a polêmica, nós tiramos isso do relatório. Ficou tão somente para a Copa do Mundo, como está disciplinado aqui no texto (referência ao substitutivo do Projeto de Lei)., ${ }^{, 563}$

Mesmo diante de uma série de denúncias de ilegalidades e problemas de políticas públicas de segurança e saúde, a única alteração foi, portanto, a limitação da bebida para as Competições. O Deputado Chico Alencar (PSOL/RJ), ciente dessa exceção, manifestou-se no plenário:

\begin{abstract}
Quer que seja permitida a venda de bebidas alcoólicas. Quer dizer, para aquela competição, pode. O torcedor se comportará direitinho, de acordo com o padrão civilizado europeu. Ora, essa é uma mentalidade neocolonialista e senzaleira relativamente à população. As grandes empresas vão ganhar quanto? Será que a Brahma, a Antarctica vão ter lucros extraordinários. Nós somos contra qualquer exceção ao Estatuto do Torcedor, em respeito ao nosso próprio trabalho aqui, aprovado, inclusive, por unanimidade, que permitiu alguns avanços no futebol brasileiro no sentido dos direitos do consumidor ${ }^{564}$.
\end{abstract}

Outros deputados, como a Frente Parlamentar Evangélica, defenderam a proibição da bebida alcoólica com base nos seus valores partidários de família e religião, como sustentou o Deputado André Moura (PSC-SE):

A posição do PSC é exatamente em defesa da família e contra a comercialização e venda de bebidas alcoólicas dentro das arenas e dos estádios durante a Copa das Confederações e também durante a Copa do Mundo. Volto a repetir: a família sempre foi e continuará sendo uma posição firme e ideológica do PSC. Exatamente em respeito à família e àquilo que conquistamos, a proibição da venda de bebida alcoólica, que já faz parte do Estatuto do Torcedor desde 2003 e foi mantida na revisão de 2010, não podemos retroceder ${ }^{565}$.

Dessa forma, a formação do contraditório sobre o tema é alcançada por posicionamentos de diferentes grupos partidários fundados em variados argumentos. Mas há

\footnotetext{
${ }^{563}$ BRASIL. CÂMARA DOS DEPUTADOS. Detaq - Discursos e Notas Taquigráficas. Sessão: 0032/12. Data: 28/02/2012.

${ }^{564}$ BRASIL. CÂMARA DOS DEPUTADOS. Detaq - Discursos e Notas Taquigráficas. Sessão: 0032/12. Data: 28/02/2012.

${ }^{565}$ BRASIL. CAMARA DOS DEPUTADOS. Detaq - Discursos e Notas Taquigráficas. ANDRÉ MOURA (PSC-SE) .Data: 28/03/2012. Hora: 19:36. Sessão: 059.2.54. Brasília.
} 
alguns traços comuns: a tentativa de demonstrar a inviolabilidade de uma lei e política pública nacional. Contudo, a transferência legislativa se torna, nesse caso, literalmente uma corrupção legislativa: o grupo privado que patrocina essa modificação e a Copa do Mundo é um dos mais importantes parceiros da FIFA, a AB InBev -proprietária da marca Budweiser (e Brahma no Brasil entre outras)-, que renovou o contrato com a FIFA por cerca de 25 milhões de dólares por ano, o que "certamente torna inviável que a FIFA promova uma Copa do Mundo sem garantir à Budweiser um espaço de destaque nos estádios da Copa."566

Essa relação foi denunciada pelos deputados. Como também é deflagrada indignação com o "compromisso internacional" assumido pelo Presidente brasileiro à época com a FIFA. Como se observa no apelo do Deputado Vanderlei Macris para que não fosse aprovado o art. 29 (que autoriza a venda de bebidas alcoólicas), votado em destaque, na Comissão:

Faço um apelo aos Parlamentares desta Comissão no sentido de que retiremos desse projeto o art. 29. Eu compreendo, Deputado Vicente Candido. V. Exa. é da base do Governo, é do PT, tem responsabilidade com o compromisso internacional feito pelo Presidente Lula, quando foi buscar a Copa do Mundo para o Brasil. Mas é a decisão do Executivo. Nós vivemos num regime democrático, e o Congresso Nacional tem de ter liberdade para adotar suas providências. A liberdade que tem neste momento é a de manter a lei que temos no País. Há apenas o interesse de manter um compromisso internacional, feito por ocasião da escolha da sede da Copa, mas o Legislativo brasileiro tem de ter independência. Ele é independente, e precisa mostrar que é. Ou seja, deve manter a lei que proíbe a venda de bebidas alcoólicas nos estádios. Nós temos dados de mais de 30 audiências públicas que mostram como é nociva a presença da bebida alcoólica na sociedade brasileira atualmente. Nós temos impressionantes dados a serem ofertados ${ }^{567}$ (grifo nosso).

O último destaque grifado da passagem demonstra um descompasso da proposta de alteração e das audiências públicas realizadas em torno do tema. Além disso, a literatura sobre violência nos estádios confirma que o consumo de bebidas alcoólicas é um dos fatores determinantes para a diminuição da violência ${ }^{568}$. "Se as primeiras doses de álcool possibilitam um efeito socializador, no entanto, as doses seguintes podem estimular a violência,

\footnotetext{
566 VEJA, Cerveja da Copa renova com Fifa. E ganha força para 2014. 25/10/2011. Disponível em $\langle$ http://veja.abril.com.br/noticia/esporte/cerveja-da-copa-renova-com-fifa-e-ganha-forca-para-2014〉 Acesso em 10/10/13.

${ }^{567}$ BRASIL. CÂMARA DOS DEPUTADOS. Detaq - Discursos e Notas Taquigráficas. Sessão: 0032/12. Data: 28/02/2012.

${ }_{568}$ ASSIS, V. P. Análise do uso de bebidas alcoólicas nas dependências do Estádio Magalhães.

Pinto (Mineirão). Condor - Boletim Médico da Clínica de Dor e do Laboratório Tafuri, ano IV, n. 20, p. 5 , 2007; REIS, H. H. B. Futebol e sociedade: as manifestações da torcida. Tese (Doutorado em Educação Física) - Faculdade de Educação Física, Universidade Estadual de Campinas, Campinas, 1998.
} 
agressividade e a impetuosidade, capazes de levar o jovem a assumir atitudes de risco, já que ele tem seu poder de avaliação reduzido, sendo um dos problemas de seu consumo em estádios de futebol." 569

Não apenas a literatura da área é desfavorável ao consumo de bebidas alcoólicas, como também a população manifestou-se amplamente contra a ideia da venda de bebidas em estádios durante a Copa:

De acordo com pesquisa realizada pelo DataSenado, $80 \%$ dos brasileiros são contra a venda de bebidas alcoólicas nos estádios durante os jogos da Copa do Brasil em 2014, tendo em vista a legislação federal existente no país. Segundo essa parcela da população, o Brasil não deve abrir exceções. Para cerca de 19\%, contudo, a bebida deve ser liberada; e $1 \%$ não soube opinar ou não quis responder ${ }^{570}$.

Mas, a despeito do posicionamento da população, dos especialistas da área e da lei, a FIFA conseguiu modificar a legislação para a venda de bebidas alcoólicas durante as competições. Esse resultado salienta uma corrupção sistêmica ativa, que predomina em relação a qualquer outro valor.

Mesmo diante de tamanhas evidências, a arte do contraditório nos premia com declarações de lados opostos do debate. Com um voto em favor da aprovação das bebidas alcoólicas, o Deputado Andre Figueiredo (PDT-CE) apresentou uma teoria diferente da literatura e dos outros colegas:

Quero tocar em alguns pontos. Um deles é que vejo que há grande mobilização da sociedade - talvez uma boa parte da sociedade que não frequenta estádio de futebol - em relação a essa celeuma sobre bebida alcoólica dentro de estádio. O problema maior da bebida alcoólica não ocorre dentro do estádio, mas em seu entorno, antes do jogo. Hoje em dia, o que vemos é que, infelizmente, a grande maioria dos espectadores de jogos de futebol, por ser proibida a bebida dentro dos estádios, deixa para entrar nos 5 minutos que antecedem a partida. Formam-se grandes aglomerações e, consequentemente, há grande risco, há badernas. Por não haver bebida alcoólica dentro do estádio, aqueles que vão beber do lado de fora brigam muito ${ }^{571}$.

\footnotetext{
${ }^{569}$ ROMERA, L. A.; REIS H. H. B. Uso de álcool entre torcedores. Motriz, Rio Claro, v.15, n.3, p.541-551, jul./set. 2009. P. 550.

${ }_{570}$ BRASIL. População não quer bebida alcoólica na Copa e $62 \%$ defendem feriado para os jogos. Data Senado, 11 abr 2012. Disponível em:

<http://www.senado.gov.br/noticias/datasenado/release_pesquisa.asp?p=39>, acesso em 8 abr. 2013.

${ }^{571}$ BRASIL. CÂMARA DOS DEPUTADOS. Detaq - Discursos e Notas Taquigráficas. Sessão: 0032/12. Data: 28/02/2012.
} 
Esse depoimento ímpar se coaduna com um dos argumentos mais repetidos pelos deputados em favor da alteração no Estatuto do Torcedor para a Copa do Mundo: a tentativa de minimizar o fato perante a "grandiosidade" de uma Copa no Brasil. Além disso, a bancada governista também se utilizou dos argumentos que giravam em torno do "compromisso com a FIFA" e do fato de "cerveja ser vendida em todas as Copas do Mundo". Essas duas últimas teses podem ser exemplificadas pela sustentação do Deputado Renan Filho (PMDB-AL):

Sr. Presidente, a Câmara dos Deputados não tem por prática digerir
pratos feitos. Nós temos, por costume, debater, iluminar os pontos obscuros
dos projetos. É isso que estamos fazendo neste momento. A bebida
alcoólica, a cerveja, foi vendida em todas as Copas do Mundo. Até no Catar,
Sr. Presidente Inocêncio Oliveira, país islâmico, de religião fundamentalista,
onde é proibido beber nas esquinas, onde não existem bares para vender
cerveja, na Copa do Mundo, a bebida alcóolica será liberada, porque aquele
país, assim como o Brasil, o Presidente Lula, os Ministros que assinaram
as garantias para realizar aqui um grande evento entenderam ${ }^{572}$. (grifo
nosso)

De fato, o entrelaçamento e a corrupção sistêmica (transnacional-nacional) não decorrem de fragilidade, nem ameaçam apenas o sistema jurídico e político brasileiros, mas são verificados em outros países. Desde 1982, quando a Budweiser começou a patrocinar a Copa do Mundo, com exceção de apenas uma das sedes - na Alemanha -, todos os estádios das últimas Copas só puderam vender cerveja da marca Budweiser. Em 2006, na Copa alemã, após polêmica, ataques da opinião pública e da imprensa ao regulamento que proibia a venda de cervejas alemãs nos estádios da Copa, concluiu-se um acordo quase simbólico que liberava a venda de bebidas da marca Bitburger, patrocinadora oficial da seleção alemã, nos arredores dos estádios ${ }^{573}$.

Contraditoriamente, parece que nem mesmo a FIFA tem uma política definitiva sobre $\mathrm{o}$ assunto. Foi essa a justificativa da emenda mais discutida do plenário, a emenda $\mathrm{N}{ }^{\mathrm{o}} 15$ da deputada Carmen Zanotto (PPS/SC), que relata que havia explícita proibição de bebida alcoólica no "Caderno de Diretrizes de Segurança" de 2004, escrito pela própria FIFA. Nele,

\footnotetext{
572 BRASIL. CAMARA DOS DEPUTADOS. Detaq - Discursos e Notas Taquigráficas. RENAN FILHO (PMDB-AL). Data: 28/03/2012. Sessão: 059.2.54. Brasília.

${ }^{573}$ LANDLER, Mark. The Hard Sell in Frankfurt. The New York Times. Publicado 7 de junho de 2006. Disponível em<http://www.nytimes.com/2006/06/07/business/media/07adco.html?pagewanted=all $>$ Acesso em 10/10/13; CHARBONNEAU Louis. Bud faces tough taste test in World Cup Germany. Agência Reuters. SPORTS ESPN. Publicado 7 de junho de 2006 Disponível em <http://sports.espn.go.com/espn/wire?section=soccer\&id=2438139> acesso em 10/10/13.
} 
o art. 19 determinava o banimento da venda e consumo de bebida alcoólica no interior dos estádios em todas as partidas ou eventos de sua responsabilidade ${ }^{574}$.

Em 2008, porém, a FIFA editou o caderno Safety Regulations e "flexibilizou" a regra que antes pretendia banir o álcool nos estádios. Certamente essa alteração levou em conta que a FIFA tornou-se parceira comercial da INBEV, fabricante da cerveja Budweiser, um dos patrocinadores dos jogos. Pergunta-se: a FIFA desistiu de banir o álcool quando se tornou parceira da INBEV, fabricante da cerveja Budweiser, uma das maiores patrocinadoras do jogos e cerveja mais vendida do mundo? ${ }^{575}$

Dessa forma, percebemos que o entrelaçamento de ordens legislativas no campo do futebol aconteceu por um viés dotado de falta de legitimidade, inconstitucionalidade e ilegalidades e, assim, por uma corrupção sistêmica. Mas é um caso de sucesso de entrelaçamentos de ordens, um caso em que se pode ver com clareza a iniciativa legislativa de uma ordem transnacional no seio da ordem jurídica nacional brasileira.

A ausência de participação da diplomacia parlamentar nos debates de negociação prévios à aprovação da Lei Geral da Copa é demonstrada pelo desamparo dos deputados, que não conseguiam contornar os pontos importantes, pois já havia um compromisso, ou melhor, havia um ato internacional sui generis do governo brasileiro com a FIFA.

Mesmo com seus direitos tolhidos, a atuação da diplomacia parlamentar nesse caso foi enérgica, promoveu debates e demonstrou também a riqueza de existir oposição em todos os lugares de fala de um Estado democrático. Mesmo diante da maioria numérica da bancada do governo, a oposição trouxe à tona diversos pontos não mascarados dessa relação.

\footnotetext{
574 O atual Guia de Segurança da FIFA, de fato explicita no art. 20, item "2": "A FIFA, as confederações e associações reservam o direito de restringir a posse, venda, distribuição ou consumo de bebidas alcoólicas em jogos, incluindo o tipo de bebidas que podem ser vendidos, onde podem ser consumidas bebidas alcoólicas, ou a proibição de álcool, de acordo como apropriadas às circunstâncias." In: FIFA. Fédération Internationale de Football Association.Safety Regulations. Zurique, Suíça. 2013.

${ }^{575}$ BRASIL. CÂMARA DOS DEPUTADOS. Projeto de Lei N. 2.330/2011. Emenda de Plenário N. 15. Deputada Carmen Zanotto (PPS/SC). Brasília. 28/03/2012.
} 


\section{RESULTADOS E CONSIDERAÇÕES FINAIS}

Conquistar a democracia é, inicialmente, reinventá-la.

Mireille Delmas-Marty

O entrelaçamento de diferentes ordens legislativas parece ser um fenômeno indissociável do futuro das relações internacionais e do direito internacional. Os novos atores, como representantes legislativos, na figura da diplomacia parlamentar, e de ordens privadas da ordem legislativa transnacional, não demonstram, nos seus discursos ou na forma de atuar, motivações ou tendências a minguar seu protagonismo no plano político internacional. Talvez o mais interessante sobre a política internacional seja que suas inúmeras variáveis e hipercomplexidade tornam o plano global uma expectativa em que não se tem controle, tampouco possibilidade de previsão. O espaço de disputa política é esfera muito difusa e bastante volátil.

Os resultados imediatos do trabalho são da esfera da demonstração da existência do entrelaçamento de ordens jurídico-político nas duas relações: estatal-supranacional e estataltransnacional $^{576}$. Entretanto, com resultados opostamente localizados. Enquanto a União Europeia tem uma relação de entrelaçamento transconstitucional da sua teia de instituições

\footnotetext{
${ }^{576}$ Com esse escrutínio não foram encontrado casos de entrelaçamentos de ordens legislativas entre as seguintes ordens: estatal-internacional; estatal-estatal; internacional-supranacional. As opções do nível estatal-estatal estariam resumidas a encontros bilaterais entre países, com míngua participação parlamentar; entre os níveis estatal-internacional, a e na opção do internacional-supranacional, são ainda raras as opções de deputados europeus participando de cúpulas mundiais.
} 
supranacionais com os Estados-membros, a FIFA produziu um entrelace corrupto da sua ordem transnacional com o processo legislativo estatal brasileiro.

Para diferenciar os resultados, foram utilizados o transconstitucionalismo e os conceitos de processo e diplomacia parlamentar. O transconstitucionalismo impõe um princípio que mescla alteridade com democracia dentro de um filtro constitucional: "O diálogo transconstitucional exige a capacidade de pôr-se na posição do outro." ${ }^{, 577}$ A escolha desses artifícios teóricos se justifica na medida em que a proposta incluiu, de fato, os entrelaçamentos de ordens de diferentes níveis: estatal, transnacional e supranacional.

A revisão da literatura de processo legislativo demonstra que a maioria dos estudos são isolados, com forte conotação constitucional-nacionalista e não apresentam preocupação com nenhuma tecnologia institucional ou teórica. Os melhores estudos incluem literatura de ordem estrangeira em seus métodos. Contudo, exploramos a descrição dos processos particulares de cada caso.

O processo é poder e ideologia, principalmente se pensamos pelo viés da teoria crítica. Não há discurso que seja imunizado a uma determinada instituição de regras do jogo. Portanto, esclarecer qual ato é ligado a tal tipo de ator permite ver o que sustenta um determinado processo legislativo. Principalmente, quando se entrelaçam ordens de diferentes magnitudes, objetivos, territórios e sistemas políticos.

Com o paradigma transconstitucional, ambos os conceitos passam por um crivo democrático. Assim, diante da entropia epistemológica da diplomacia parlamentar propomos uma classificação para o conceito, diferenciando o conceito em diplomacia parlamentar eleita/não-eleita. A segunda diferenciação é diferenciada de acordo com suas principais funções: legislativa, fiscalizadora e diplomática.

Trabalhados sobre o manto do transconstitucionalismo, os conceitos de processo legislativo e diplomacia parlamentar, aos quais também se atribui status de variáveis explicativas, geraram efeitos de melhor compreensão do tipo de mudança que a diplomacia parlamentar pode sugerir ao ganhar espaço e força política.

O Tratado de Lisboa equipara o Parlamento Europeu ao Conselho, funcionando como um sedativo para o famigerado déficit democrático europeu. O diagnóstico institucional atual está em plena suspensão. O Parlamento, com novos poderes, pode alavancar uma maior preocupação com as questões europeias, principalmente num momento sensível e de absorções de mobilizações populares em torno da crise financeira e da própria qualidade de

\footnotetext{
${ }^{577}$ NEVES, M. Op. Cit. 2009.p. 146.
} 
decisões políticas: vincular uma coletividade. Essa coletividade mostra-se bastante indisposta a aceitar que se venda o futuro, mais uma vez, com preços e juros de contratos bancários. Nessa perspectiva, também se observa que os parlamentos nacionais terão destaque no novo Tratado de Lisboa, uma vez que têm formalmente maior participação.

Assim, a diplomacia parlamentar supranacional da União Europeia tem condições formais - como nenhuma outra instituição, extranacionais - de desenvolver um trabalho de diplomacia, fiscalização e legislação, as três funções da diplomacia parlamentar. A capacidade de circulação e contracirculação dos elementos administração, política stricto sensu, esfera pública e povo constitucional é efetivamente sui generis.

Com efeito, o papel da diplomacia parlamentar pode ter a capacidade de diminuir efetivamente o déficit democrático, pois que consegue ser um ator com ação nessas quatro dinâmicas. Assim, a antiga crítica da insuficiência dos poderes do Parlamento Europeu no que se refere à iniciativa dos poderes de controle e legislativo deve ser forçosamente suspensas e, futuramente, transformadas. A mobilização e competência para trazer os debates mais significativos para dentro da casa precisam ser a nova lógica de críticas e compreensão do problema democrático.

Por outro lado, ainda restam grandes desafios, tendo em vista o Poder Legislativo do Parlamento Europeu estar vinculado ao Conselho de Ministros, um órgão que representa os Estados, diferentemente do Parlamento Europeu, que representa os cidadãos da Europa. Esse controle sobre o Parlamento diminui a descentralização aos países participantes do bloco regional. Também afeta o próprio interesse, conferindo menor legitimidade e, consequentemente, menos poder - na lógica de reciprocidade - à própria busca da força do multilateralismo regional europeu.

Nesse contexto, a União Europeia, ao ser comparada ao Estado como estrutura supranacional, parece não desvelar o fato de a instituição do Estado ser uma criação artificial de exclusão no sistema internacional. A soberania, representada por fronteiras e Estadosnação são ficções criadas com pouca ou nenhuma reflexão no seu aspecto excludente.

Como lembra Neves: "o poder político, no sentido sistêmico, orienta-se primariamente à tomada de decisões coletivamente vinculantes, é inegável que essas ordens estariam distantes desse problema"578. No estudo de caso Brasil/FIFA, que entrelaça as ordens nacional-transnacional, os atores privados ou quase-públicos tomam decisões que vinculam coletivamente a sociedade, mas, como não são órgãos democráticos, suas decisões

\footnotetext{
${ }^{578}$ NEVES, M. Op. Cit. 2009.p. 106.
} 
comprometem a performance democrática. Estão preocupados com o sistema econômico que financia seus serviços. Não se trata de mera influência, mas de demonstrado equivalente funcional de iniciativa legislativa na aprovação da Lei Geral da Copa.

A dominação hegemônica do sistema econômico, por mais denunciada e repetidamente enunciada, sempre é uma ingrata surpresa no momento em que sua hegemonia é desvelada. Mesmo em tempos de super-informação, a FIFA consegue esconder seu jogo de manipulação por dentre o véu consumista da população e a ambição desenvolvimentista dos governos.

Nem mesmo os websites de transparência pública ou os de espionagem de hackers privados haviam tido acesso aos formulários de garantias que o governo brasileiro assinou com a FIFA. Os documentos de outras Copas do Mundo também não são acessíveis. É tão escondido quanto o livro do Andrew Jennings: Jogo Sujo O Mundo Secreto da FIFA. Compra de Votos e Escândalo de Ingressos. Como toda máfia de dignidade, a FIFA tentou de todas as formas proibir o livro, assim como baniu e perseguiu o jornalista, segundo o próprio.

A Lei Geral da Copa modificou a legislação em ao menos três pontos fundamentais dos direitos brasileiros: a bebida alcoólica nos estádios, privilégios e isenções fiscais à FIFA e parceiros da FIFA, a criação tipos penais específicos para as Competições. Essas exceções devem ser consideradas dentro de uma perspectiva de exceções graves, pois, caso contrário, a lista seria maior: Responsabilidade Civil do governo brasileiro (incluindo indenizações) para qualquer fato ocorrido durante o período envolvendo qualquer pessoa, espectador, cidadão ou profissional da FIFA envolvido; vistos gratuitos; isenções para taxas e emolumentos.

Projeto de Lei 2.330/2011 tem 85\% de sua redação idêntica ao Formulários submetidos pela FIFA. Esses Formulários de Garantias foram inteiramente assinados pelo governo brasileiro, sem qualquer negociação ou missão diplomática. Isso demonstra uma capacidade de iniciativa legislativa da FIFA, numa forma de equivalente funcional nos entrelaçamentos legislativos, mas pela forma de corrupção sistêmica.

Resta também inconclusa a natureza jurídica do Formulário de Garantias. Não se trata de nenhum ato jurídico internacional previsto, tampouco um executive agreement. Diante de tantas garantias dadas pelo Brasil à FIFA, não há nenhuma contrapartida, ou obrigação jurídica da FIFA para realizar a Copa do Mundo no Brasil, podendo realizá-la em qualquer outro local, sem que o Brasil tenha direito a qualquer indenização.

Os documentos pesquisados e investigados tiveram sucesso somente por meio da Lei de Acesso à Informação, N. 12.527/2011, por meio do Sistema Eletrônico de Serviço ao cidadão. Esses documentos comprovam a forma de corrupção sistêmica do entrelaçamento da 
ordem transnacional da FIFA e a ordem legislativa brasileira. Esses documentos haviam sido requeridos pelos deputados e por outras entidades de transparência, mas sem sucesso. Nem mesmo o Ministério das Relações Exteriores teve acesso ao documento, como foi demonstrado.

Pelo caso explorado, podemos perceber que a diplomacia parlamentar eleita com função legislativa no plano estatal existe com certa atuação, ainda que com potencial crescente. Assim, resta ainda uma diplomacia parlamentar pouco ativa no Brasil, no processo de discussão e negociação dos tratados internacionais. O Poder Executivo negocia o tratado e posteriormente o submete a um voto de aprovação ou rejeição, sendo ele normalmente aprovado.

Mas a questão de aprovação ou não de uma determinada lei é apenas o resultado final do processo legislativo. Como observado, o debate e a inclusão de novos problemas, do outro lado, é fundamental para o desenvolvimento do transconstitucionalismo. A diplomacia parlamentar eleita com função fiscalizadora também é um elemento democrático decisivo $e$ irrevocável dentro de padrões mínimos de uma nova politização dos espaços políticos extranacionais e para a colaboração para um entrelaçamento transconstitucional desses espaços.

A democratização de alguns espaços transnacionais parece um caminho importante a ser aberto. A falta de fiscalização e accountability desses espaços são preços muito caros a se pagar por certos bens públicos globais. É inegável que o futebol seja um bem cultural. Assim, os processos de deliberação e construção de regras são abertos para que o povo constitucional seja contemplado dentro como uma figura de quem confia no sistema transnacional, ou em um mundo de conto de fadas, outra organização mais responsiva, mais democrática e menos orientada por suas empresas patrocinadoras poderá tomar a frente e construir algo em torno do futebol.

O futebol é apenas a bola da vez num estádio cheio de bens comuns globais administrados por redes privadas de propriedade e consumo: propriedade intelectual sobre remédios, agentes químicos, alimentos, engenharia genética. "Essa concepção marcadamente assimétrica da soberania, enquanto essa vale de maneira quase absoluta para o portador de determinadas formas jurídicas, é demasiadamente relativizada ou inteiramente desconsiderada no caso de formas de direito que se desviam da dominante em suas experiências com o poder, dinheiro e o saber." 579

${ }^{579}$ NEVES, M. Op. Cit. 2009.p. 252. 
Mas mostra-se notório que a diplomacia parlamentar poder ter um novo papel, assim como processos legislativos extranacionais, principalmente a diplomacia parlamentar eleita. A função legislativa englobou dois exemplos de ordens políticas e resultados completamente diferentes.

Esta imposição, de uma forma legislativa sobre a estatal, implica não uma simples desordem ou nova ordem, mas, ao contrário, o conceito de corrupção sistêmica denuncia mecanismos próprios de opressão ou negação da autonomia de formas constitucionais por outras, economicamente mais fortes.

Os resultados, assim, contrariam o diagnóstico que conta com um preconceito pelo qual não se poderia contar com as instituições parlamentares, pois estas teriam perdido força para o executivo ao longo do século passado, especialmente desde o fim da Segunda Guerra Mundial. Ao contrário, há uma ressurgente parlamentarização da política, com a proliferação de órgãos parlamentares, bem como um crescente papel internacional dos parlamentos nacionais e regionais, contradizendo empiricamente também o argumento neorrealista de que não há papel dos parlamentos nos assuntos externos.

Isso não significa, a priori, que a influência dos parlamentos é tão importante na política mundial como a de governos ou dos poderes Executivos. Mas não se deve ignorar este fenômeno, alegando que ele é relativamente novo e que seu impacto é limitado. Esses novos atores, em conjunto com o caldo hipercomplexo, colaboram para uma perspectiva diferente. A característica central da ordem que prevalece é o grau de conectividade ou desconectividade entre os atores do sistema que irão demarcar esses diversos arranjos, isto é, como o entrelaçamento de ordens, atores e instituições poderá ser proposto e observado.

No contexto do processo legislativo extranacional, a maior parte das soluções encontradas pela literatura para formas de resolução do problema do déficit democrático em ordens internacionais continua a ser atribuído ao conceito de governança.

Dos resultados aqui descritos, surgem questões não respondidas. Assim, para delimitar e potencializar o estudo da diplomacia parlamentar precisa-se pensar nas seguintes: como o grau de democratização dos espaços internacionais, por meio de redes institucionais que permitem uma atuação formal e não formal desses atores; a descentralização da política internacional como processo democrático; quem está aproveitando a descentralização e a democratização do processo legislativo internacional - quem financia campanhas ou interesses da diplomacia parlamentar -; quais forças sociais ou econômicas atuam com esse foco específico. 
Ao fim, o que se observa ainda é a privação e a necessidade da politização do processo - com a criação de plataformas e vocabulários que destaquem a contestação, a natureza política das escolhas que a globalização possui. A diplomacia parlamentar eleita tem uma capacidade - dentre as suas funções - dentro do código binário governo/oposição, ser oposição. Essa é uma possibilidade nova para as discussões internacionais e que pode significativamente colaborar para a politização do processo, melhorando a transparência de tomada de decisão, responsabilidando indivíduos e sistemas por suas escolhas.

Notar o desconforto de atores clássicos e teorias clássicas com a necessidade de debater com novos atores, com novas instituições, com um mundo de poder pulverizado, é prova de que uma pequena abertura finalmente surge. 


\section{ANEXOS}

\section{Tabela 1}

\begin{tabular}{|c|c|c|c|}
\hline Emenda & $\begin{array}{l}\text { Aprovada/ } \\
\text { Reprovada }\end{array}$ & Tema & Alteração da Lei \\
\hline $1 / 2012$ & REPROVADA & $\begin{array}{lr}\text { Vedação } & \text { ao } \\
\text { Comércio de bebidas } \\
\text { alcoólicas } \\
\text { estádios }\end{array}$ & $\begin{array}{l}\text { Inclui o art. } 28 \text {-a e altera o art. } 43 \text { do } \\
\text { Substitutivo da Comissão Especial } \\
\text { oferecido ao Projeto de Lei } n^{\circ} \\
2.330 / 2011 \text {. }\end{array}$ \\
\hline $2 / 2012$ & REPROVADA & $\begin{array}{lr}\text { Vedação } & \text { ao } \\
\text { Comércio de bebidas } \\
\text { alcoólicas } \\
\text { estádios }\end{array}$ & Inclui o art. 34-a e altera o art. 43. \\
\hline $3 / 2012$ & APROVADA & 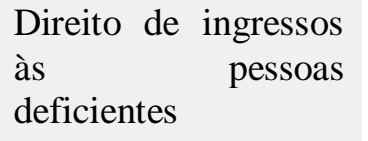 & Altera o $\S 5^{\circ}$ do art. 26 . \\
\hline $4 / 2012$ & APROVADA & $\begin{array}{lr}\text { Direito de } & \text { ingressos } \\
\text { às } & \text { pessoas } \\
\text { deficientes } & \end{array}$ & $\begin{array}{l}\text { Acrescenta parágrafo } 10^{\circ} \text { ao art. } 26 \\
\text { do }\end{array}$ \\
\hline $5 / 2012$ & REPROVADA & $\begin{array}{ll}\text { Direitos } & \text { de } \\
\text { Transmissão } & \text { de } \\
\text { televisão } & \end{array}$ & Altera $0 \S 3^{\circ}$ do art. 15 . \\
\hline $6 / 2012$ & APROVADA & $\begin{array}{l}\text { Segurança em } \\
\text { aeroportos militares }\end{array}$ & Acrescenta parágrafo ao art. 60 \\
\hline $7 / 2012$ & APROVADA & $\begin{array}{l}\text { Aprimoramento de } \\
\text { Redação }\end{array}$ & Dá nova redação aos arts. 70 e 71 . \\
\hline $8 / 2012$ & REPROVADA & $\begin{array}{l}\text { Responsabilização } \\
\text { judicial da FIFA }\end{array}$ & Suprime o art. 51. \\
\hline 9/2012 & REPROVADA & $\begin{array}{l}\text { Limitar a isenção } \\
\text { tarifária aos vistos } \\
\text { para turistas }\end{array}$ & Dá nova redação ao art. 21. \\
\hline
\end{tabular}


10/2012 APROVADA Regula comércio de rua e licenciamento FIFA

11/2012 REPROVADA

Trata de concessão de vistos para o Brasil

12/2012 REPROVADA

Sobre ponto facultativo ao serviço público.

\begin{tabular}{|l|l|l|}
\hline $13 / 2012$ & REPROVADA & $\begin{array}{l}\text { Desconto } \\
\text { estudantes } \\
\text { ingressos }\end{array}$ \\
\hline $14 / 2012$ & REPROVADA & $\begin{array}{r}\text { nos } \\
\text { Desconto para } \\
\text { estudantes, idosos e } \\
\text { hipossuficientes; }\end{array}$ \\
\hline
\end{tabular}

15/2012 REPROVADA Proibição de bebidas alcoólicas

16/2012 REPROVADA Em desfavor da isenção do INPE à FIFA;

17/2012 REPROVADA

Sobre o dever da FIFA de se submeter ao Código do Consumir

18/2012 REPROVADA

Altera termo de registro no INPI

19/2012 REPROVADA

Produção nacional dos bens.

20/2012 REPROVADA

Meia-entrada para estudantes.

21/2012 APROVADA

Exclusividade dos direitos comerciais da FIFA.

Dever do governo de instalar telões em lugares públicos
Altera o art. 11 e os incisos i a iii do art. 16.

Altera o $\S 4^{\circ}$ do art. $9^{\circ}$ da lei $n^{\circ}$ 6.815/80, constante do art. 50 .

Altera o parágrafo único do art. 57.

Acrescenta o $\S 4^{\circ}$ ao art. 26.

Altera o $\S 3^{\circ}$ do art. 26.

Suprime o art. 29.

Suprime o art. 10.

Dá nova redação ao art. 27.

Suprime o art. $9^{\circ}$.

Inclui novo dispositivo à Lei.

Suprime o $\S 6^{\circ}$ do art. 26.

Dá nova redação aos artigos 11 e 16 do substitutivo ao projeto de lei $\mathrm{n}^{\circ}$ 2.330/11.

Altera o art. 57. 


\begin{tabular}{|c|c|c|c|}
\hline $23 / 2012$ & REPROVADA & $\begin{array}{lr}\text { Aplicação } & \text { do } \\
\text { Estatuto } & \text { do } \\
\text { Torcedor, } & \text { Lei } \\
10.671 . & \end{array}$ & Dá nova redação ao art. 67. \\
\hline 24/2012 & REPROVADA & $\begin{array}{l}\text { Revogar a exceção à } \\
\text { FIFA nas normas } \\
\text { gerais nacionais } \\
\text { sobre desporto. }\end{array}$ & $\begin{array}{l}\text { Suprime o art. } 29 \text { e, por } \\
\text { consequência, a } \text { expressão } \\
\text { "excetuado o disposto nos art. 13- } \\
\text { a", constante do art. } 67 \text {. }\end{array}$ \\
\hline 25/2012 & REPROVADA & $\begin{array}{l}\text { Obrigatoriedade de } \\
\text { venda de bebidas em } \\
\text { material de plástico }\end{array}$ & Dá nova redação ao art. 29. \\
\hline 26/2012 & REPROVADA & $\begin{array}{l}\text { Cláusula penal para } \\
\text { desistência de } \\
\text { compra de ingresso }\end{array}$ & Altera o inciso iii do art. 27. \\
\hline $27 / 2012$ & APROVADA & $\begin{array}{lrr}\text { Garantir } & \text { direito } & \text { à } \\
\text { manifestação } & \text { e } & \text { à } \\
\text { liberdade } & & \text { de } \\
\text { expressão } & & \end{array}$ & $\begin{array}{l}\text { Acrescenta parágrafo ao art. } 28, \\
\text { renumerando-se o parágrafo único } \\
\text { para } \S 1^{\circ} \text {. }\end{array}$ \\
\hline 28/2012 & REPROVADA & $\begin{array}{lr}\text { Regulação e limites } \\
\text { do } & \text { trabalho } \\
\text { voluntário } & \end{array}$ & Acrescenta parágrafos ao art. 50. \\
\hline 29/2012 & REPROVADA & $\begin{array}{l}\text { Proibição } \\
\text { Trabalho Escravo e } \\
\text { Infantil. }\end{array}$ & Acrescenta parágrafos ao art. 55. \\
\hline $30 / 2012$ & REPROVADA & $\begin{array}{l}\text { Direito ao comércio } \\
\text { de rua, ambulante e } \\
\text { informal. }\end{array}$ & Altera $\S 2^{\circ}$ do art. 11. \\
\hline $31 / 2012$ & REPROVADA & $\begin{array}{l}\text { Proibição de bebidas } \\
\text { alcoólicas }\end{array}$ & Suprime o art. 29. \\
\hline $32 / 2012$ & REPROVADA & $\begin{array}{l}\text { Sobre tipologia de } \\
\text { gramados para } \\
\text { estádios da Copa. }\end{array}$ & Incluir novo artigo à Lei. \\
\hline $33 / 2012$ & REPROVADA & $\begin{array}{l}\text { Sobre tipologia de } \\
\text { gramados para } \\
\text { estádios da Copa. }\end{array}$ & Incluir novo artigo à Lei. \\
\hline $34 / 2012$ & REPROVADA & $\begin{array}{l}\text { Identificação de } \\
\text { comprovação de } \\
\text { condição de }\end{array}$ & Altera $\S 8^{\circ}$ do art. 26. \\
\hline
\end{tabular}


estudante.

35/2012 APROVADA Regulamenta manual de venda e sorteio de ingressos.

$36 / 2012$

APROVADA

$37 / 2012$

APROVADA

Regulamenta tipos compra de ingressos disponíveis.

Regulamenta prazo para compra de ingressos.

Regulamenta tipos compra de ingressos disponíveis, em especial aos portadores de deficiência.

\section{$39 / 2012$}

REPROVADA

Obriga a União a seguir a lei de Licitações para compra de Seguro.

$40 / 2012$

REPROVADA

Equipara o Brasil à

FIFA para

determinar o preço dos ingressos.

41/2012 REPROVADA

Vedação ao Comércio de bebidas alcoólicas em estádios.

\begin{tabular}{|l|l|l|}
\hline 42/2012 & APROVADA & $\begin{array}{l}\text { Zona exclusiva de } \\
\text { comércio para } \\
\text { produtos licenciados } \\
\text { FIFA. }\end{array}$ \\
\hline
\end{tabular}

$43 / 2012$

REPROVADA

Criação do Fundo Especial de Saúde ao Jogador de Futebol.
Necessidade de embalagens plásticas para Bebidas alcoólicas.
Acrescenta parágrafos ao art. 26.

Acrescenta parágrafos ao art. 26.
Altera $\S 5^{\circ}$ do art. 26.
Altera $\S 2^{\circ}$ do art. 26.

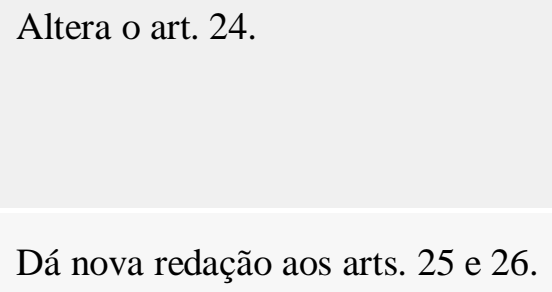

Dá nova redação aos arts. 25 e 26.

Altera o art. 24.

Suprime o art. 29.

Modifica os arts. 11 e 16.

Incluiu novo artigo à Lei.

Altera o art. 29. 


\begin{tabular}{|c|c|c|c|}
\hline $45 / 2012$ & REPROVADA & $\begin{array}{l}\text { Proibição de bebidas } \\
\text { alcoólicas e } \\
\text { aplicação do Estatuto } \\
\text { do Torcedor. }\end{array}$ & Altera o art. 67. \\
\hline $46 / 2012$ & REPROVADA & $\begin{array}{l}\text { Necessidade de } \\
\text { embalagens plásticas } \\
\text { para Bebidas } \\
\text { alcoólicas. }\end{array}$ & Altera o art. 29 e o art. 67. \\
\hline 47/2012 & REPROVADA & $\begin{array}{l}\text { Aplicação do } \\
\text { Estatuto do Torcedor } \\
\text { e Código do } \\
\text { Consumidor. }\end{array}$ & Suprime os arts. 63 e 67. \\
\hline 48/2012 & REPROVADA & $\begin{array}{l}\text { Revogação de } \\
\text { direitos especiais } \\
\text { para vistos. }\end{array}$ & $\begin{array}{l}\text { Modifica o art. } 19 \text { do substitutivo } \\
\text { aprovado na comissão especial, } \\
\text { referente ao projeto de lei n. } 2330 \text {, } \\
\text { de } 2011 \text {. }\end{array}$ \\
\hline 49/2012 & REPROVADA & $\begin{array}{l}\text { Regulamenta } \\
\text { ingressos para } \\
\text { estudantes, idosos, } \\
\text { hipossuficientes, } \\
\text { indígenas e } \\
\text { portadores de } \\
\text { deficiência. }\end{array}$ & $\begin{array}{l}\text { Modifica o artigo } 26 \text { do pl 2330, de } \\
2011 .\end{array}$ \\
\hline $50 / 2012$ & REPROVADA & $\begin{array}{l}\text { Vedação ao } \\
\text { Comércio de bebidas } \\
\text { alcoólicas em } \\
\text { estádios. }\end{array}$ & Modifica o art. 29 do \\
\hline $51 / 2012$ & APROVADA & $\begin{array}{l}\text { Construção de } \\
\text { Centros de } \\
\text { Treinamento de } \\
\text { Atletas; pessoas com } \\
\text { deficiência; doenças } \\
\text { raras. }\end{array}$ & Altera o inciso ii do art. 30 \\
\hline $52 / 2012$ & REPROVADA & $\begin{array}{l}\text { Revoga privilégios } \\
\text { do INPI. }\end{array}$ & Altera os arts. $4^{\circ}, 6^{\circ}$ e $7^{\circ}$ \\
\hline $53 / 2012$ & REPROVADA & $\begin{array}{l}\text { Regular o Serviço } \\
\text { Voluntário da FIFA. }\end{array}$ & $\begin{array}{l}\text { Modifique-se o artigo } 58 \text { do } \\
\text { substitutivo aprovado na comissão } \\
\text { especial, referente ao projeto de lei } \\
\text { n. } 2330 \text {, de } 2011 \text {. }\end{array}$ \\
\hline $54 / 2012$ & REPROVADA & $\begin{array}{l}\text { Revoga a } \\
\text { exclusividade de área }\end{array}$ & $\begin{array}{l}\text { Modifica os artigos } 11 \text { e } 12 \text { do } p l \\
2330 \text {, de } 2011 \text {. }\end{array}$ \\
\hline
\end{tabular}


de vendas da FIFA.

\begin{tabular}{|c|c|c|c|}
\hline $55 / 2012$ & REPROVADA & $\begin{array}{l}\text { Direitos de } \\
\text { Transmissão da } \\
\text { FIFA. }\end{array}$ & $\begin{array}{l}\text { Modifica o artigo } 16 \text { do pl 2330, de } \\
2011 .\end{array}$ \\
\hline $56 / 2012$ & REPROVADA & $\begin{array}{l}\text { Suprime } \\
\text { Responsabilidade } \\
\text { Civil da União. }\end{array}$ & $\begin{array}{l}\text { Suprime todo o capitulo iv e, } \\
\text { portanto, os artigos } 22,23 \text { e } 24 \text { do } \\
\text { substitutivo aprovado na comissão } \\
\text { especial, referentes ao projeto de lei } \\
2330 \text {, de } 2011 \text {. }\end{array}$ \\
\hline $57 / 2012$ & REPROVADA & $\begin{array}{l}\text { Suprime tipos penais } \\
\text { em torno da pirataria. }\end{array}$ & $\begin{array}{l}\text { Altera os artigos } 31 \text { e } 32 \text { do } \\
\text { substitutivo aprovado na comissão } \\
\text { especial do projeto de lei n. } 2330 \text {, } \\
\text { de } 2011 \text {. }\end{array}$ \\
\hline $58 / 2012$ & REPROVADA & $\begin{array}{lr}\text { Proíbe } & \text { privatização } \\
\text { dos } & \text { estádios } \\
\text { públicos. } & \end{array}$ & $\begin{array}{l}\text { Substitui o artigo } 70 \text { do substitutivo } \\
\text { aprovado na comissão especial, } \\
\text { referente ao projeto de lei n. } 2330 \text {, } \\
\text { de } 2011 \text {, que passa a ter a seguinte } \\
\text { redação, renumerando os demais } \\
\text { artigos. }\end{array}$ \\
\hline $59 / 2012$ & REPROVADA & $\begin{array}{l}\text { Obrigatoriedade de } \\
\text { venda de bebidas em } \\
\text { material de plástico. }\end{array}$ & $\begin{array}{l}\text { Modifica o artigo } 29 \text { do substitutivo } \\
\text { aprovado na comissão especial, } \\
\text { referente ao pl } 2330 \text {, de } 2011 \text {. }\end{array}$ \\
\hline 60/2012 & REPROVADA & $\begin{array}{l}\text { Definição de } \\
\text { identificação } \\
\text { estudantil. }\end{array}$ & $\begin{array}{l}\text { Altera o art. } 26 \text { e o } \$ 8^{\circ} \text { do art. } 26 \text { do } \\
\text { capítulo v do aditivo ao projeto de } \\
\text { lei } \mathrm{n}^{\circ} 2330 \text { de } 2011 \text { a seguinte } \\
\text { redação: a comprovação da } \\
\text { condição de estudante, para efeito } \\
\text { da compra dos ingressos de que } \\
\text { trata o inciso } \mathrm{i}, \S 3^{\circ} \text { deste artigo é } \\
\text { obrigatória e se dará mediante a } \\
\text { apresentação da carteira de } \\
\text { identificação estudantil, conforme } \\
\text { modelo único nacionalmente } \\
\text { padronizado por este projeto nos } \\
\text { termos do anexo i. }\end{array}$ \\
\hline
\end{tabular}

$61 / 2012$

REPROVADA
Vedação a

Propaganda de

bebidas alcoólicas

em estádios.
Altera o parágrafo único do art. $1^{\circ}$ da Lei 9.294/96.

\section{2/2012 REPROVADA Define instituição Altera o $\S 8^{\circ}$ do art. 26 \\ 62/2012 REPROVADA Define instituição Altera o $\S 8^{\circ}$ do art. 26}




\begin{tabular}{|c|c|c|c|}
\hline & & $\begin{array}{l}\text { estudantil } \\
\text { competente para } \\
\text { emissão de carteiras } \\
\text { estudantis. }\end{array}$ & \\
\hline $64 / 2012$ & REPROVADA & $\begin{array}{l}\text { Direito a } \\
\text { proprietários de } \\
\text { cadeiras de estádios. }\end{array}$ & Inclui artigo novo à Lei. \\
\hline $65 / 2012$ & REPROVADA & $\begin{array}{l}\text { Destinação de } \\
\text { receitas com bebidas } \\
\text { alcoólicas para } \\
\text { tratamento de } \\
\text { dependentes } \\
\text { químicos. }\end{array}$ & I Inclui artigo $\S 2^{\circ}$, ao artigo 29. \\
\hline $66 / 2012$ & REPROVADA & $\begin{array}{l}\text { Definição de bebida } \\
\text { alcoólica. }\end{array}$ & Inclui artigo novo à Lei. \\
\hline ESP 63 & APROVADA & $\begin{array}{l}\text { Emenda Substitutiva } \\
\text { Global que inclui } \\
\text { todas as } \\
\text { modificações. }\end{array}$ & $\begin{array}{l}\text { DISPÕE SOBRE AS MEDIDAS } \\
\text { RELATIVAS À COPA DAS } \\
\text { CONFEDERAÇÕES FIFA DE } \\
2013 \text { E À COPA DO MUNDO } \\
\text { FIFA DE 2014, QUE SERÃO } \\
\text { REALIZADAS NO BRASIL. }\end{array}$ \\
\hline
\end{tabular}




\section{REFERÊNCIAS}

ACCIOLY, Hildebrando; SILVA, Geraldo Eulálio N; e CASELLA, Paulo Borba. Manual de Direito Internacional Público, $\mathbf{1 6}^{\mathbf{a}}$ ed. (revista, atualizada e ampliada). São Paulo: Saraiva, 2008.

AGAMBEN, Giorgio. Note liminaire sur le concept de démocratie, In: AGAMBEN, Giorgio et all. (Org.) Démocratie, dans quel état? Paris: La Fabrique editions, 2009.

AGÊNCIA DEUTSCHE WELLE. OCDE aponta aumento de abismo entre pobres e ricos na Europa. Carta Capital. 16/05/2013. Internacional. 2013.

AGÊNCIA SENADO. Aprovado protocolo que inclui a Venezuela no Mercosul. Disponível em: <http://www12.senado.gov.br/noticias/materias/2009/12/15/aprovadoprotocolo-que-inclui-a-venezuela-no-mercosul> Acesso em 10/10/13.

ALBUQUERQUE, Del Roberto Chacón. El Mercosur y la adhesión de Venezuela. Revista De Derecho Público. ${ }^{\circ}{ }^{111}$. Venezuela, 2007.

ALENCAR, Chico. Estado Futebolístico de Exceção. A Folha de São Paulo. Opinião. São Paulo, 15/04/12.

ALLMERS, Swantje; MAENNIG, Wolfgang. Economic impacts of the FIFA Soccer World Cups in France 1998, Germany 2006, and outlook for South Africa 2010. Eastern Economic Journal, 35, (500-519), 2009.

ALVAREZ, José. E. International Organizations as Law-Makers. New York: Oxford University Press, 2005.

AMARAL JÚNIOR, Alberto do. Curso de Direito Internacional Público. $2^{\text {a }}$ Ed. São Paulo: Editora Atlas, 2011.

ARCHICK, Kristin. The European Parliament. Congressional Research Service. CRS. July 29, 2013. www.crs.gov Disponível em < https://www.fas.org/sgp/crs/row/RS21998.pdf> Acesso em 12/11/13.

ARGENTINA, Congreso de La Nación. Lei 26.192/2006. InfoLeg. Centro de Documentación e Información. Disponível em <http://www.infoleg.gov.ar/infolegInternet/anexos/120000-124999/122924/norma.htm> Acesso em 11/11/13. 
ARIOSI, Mariângela. Conflitos entre tratados internacionais e leis internas: o Judiciário e a Nova Ordem Internacional. Rio de Janeiro: Renovar, 2000.

ARNAUD, André-Jean. Eliane Botelho.(orgs). Dicionário da Globalização. Rio de Janeiro: Lumen Juris, 2006.;

O Direito entre Modernidade e globalização:lições de filosofia do direito e do Estado. Rio de Janeiro: Renovar, 1999.

ASSIS, V. P. Análise do uso de bebidas alcoólicas nas dependências do Estádio Magalhães. In: Pinto, Condor - Boletim Médico da Clínica de Dor e do Laboratório Tafuri, ano IV, n. 20, p. 5, 2007;

BACOT, Paul. Parlement, Région, Securité, Existence et dénomination des institutions parlamentaires internationales. In : HASSAN-YARI, Houchang ; OUSMAN, Abdelkérim. Régionalisme et sécurité internationale. Bruxelas : Bruylant, 2009.

BAILEY, Thomas Andrew. Woodrow Wilson and the great betrayal. Macmillan, 1945.

BARALDI, C.; VENTURA, D. F. L.; ILLES, P. Proteção aos migrantes. In: Liliana Lyra Jubilut; Alexandre Gustavo Melo Franco Bahia; José Luiz Quadros de Magalhães. (Org.). Direito à diferença. 1ed. São Paulo: Saraiva, 2013, v., p. 441-462.

BARBOSA, Leonardo Augusto de Andrade. Processo Legislativo e democracia: parlamento, esfera pública e jurisdição constitucional. Belo Horizonte: Del Rey, 2010.

BÄTTIG, M.,T. Bernauer, "National institutions and global public goods: are democracies more cooperative in climate change policy?," International Organization 63, 2, (2009): 281-308.

BAUMAN, Zygmunt. Globalização: as conseqüências humanas. Trad. Marcus Penchel. Rio de Janeiro: Jorge Zahar Ed., 1999.

BERCOVICI, G. Dilemas do estado federal brasileiro. Porto Alegre: Livraria do Advogado, 2004.

BEYERS, Jan. International Institutions and Socialization in Europe. International Organization. Vol. 59, No. 4, pp. 899-936. 2005.

BO, João Batista Lanari. Proteção do Patrimônio da UNESCO: ações e significados. Brasília: UNESCO, 2003.

BOBBIO, N. A teoria das formas de governo. 10. ed. Brasília: UnB, 1997.

BOBBIO, Norberto. Dicionário de política. 10. ed. Sérgio Bath. Brasília: UnB, 1997.

BODIN, Jean. Les Six livres de la République: un abrégé du texte de l'édition de Paris de 1583. Ed. Gérard Mairet. Paris, Librairie générale française, 1993. 
BONAVIDES, Paulo. Ciência Política. São Paulo: Malheiros, 2006.

BOYLE, Alan E. CHINKIN, C. M. The making of international law. Oxford University Press, 2007.

CÃMARA DOS DEPUTADOS. Comissão Especial Destinada a Proferir parecer ao Projeto de Lei N. 2.330/2011. Relatório. Relator: Deputado Vicente Cândido.

CÂMARA DOS DEPUTADOS. Deputado Paulo Pereira da Silva Detaq

- Discursos e Notas Taquigráficas. Sessão: 0032/12. Data: 28/02/2012.

CAMARA DOS DEPUTADOS. Detaq - Discursos e Notas Taquigráficas. JILMAR TATTO (PT-SP). Data: 28/03/2012. Sessão: 059.2.54.0 Brasília.

CAMARA DOS DEPUTADOS. Detaq - Discursos e Notas Taquigráficas. Debate do Plenário. VANDERLEI MACRIS (PSDB-SP) Data: 28/03/2012. Sessão: 059.2.54.0. Brasília.

CAMARA DOS DEPUTADOS. Detaq - Discursos e Notas Taquigráficas. VANDERLEI MACRIS (PSDB-SP). Data: 28/03/2012. Sessão: 032.2.54.0. Brasília.

CAMARA DOS DEPUTADOS. Detaq - Discursos e Notas Taquigráficas. Deputada CARMEN ZANOTTO (PPS-SC). Data: 28/03/2012. Hora: 19:36. Sessão: 059.2.54.O. Brasília.

CAMARA DOS DEPUTADOS. Detaq - Discursos e Notas Taquigráficas. ANDRÉ MOURA (PSC-SE) .Data: 28/03/2012. Hora: 19:36. Sessão: 059.2.54. Brasília.

CAMARA DOS DEPUTADOS. Detaq - Discursos e Notas Taquigráficas. RENAN FILHO (PMDB-AL). Data: 28/03/2012. Sessão: 059.2.54. Brasília.

CÂMARA DOS DEPUTADOS. Detaq - Discursos e Notas Taquigráficas. Sessão: 0032/12. Data: 28/02/2012.

CÂMARA DOS DEPUTADOS. Projeto de Lei N. 2.330/2011. Emenda de Plenário N. 53. Ivan Valente (PSOL/RJ) Brasília. 28/03/2012.

CÂMARA DOS DEPUTADOS. Projeto de Lei N. 2.330/2011. Emenda de Plenário N. 29. Vicentinho (PT/SP) Brasília. 28/03/2012.

CÂMARA DOS DEPUTADOS. Projeto de Lei N. 2.330/2011. Emenda de Plenário N. 30. Vicentinho (PT/SP) Brasília. 28/03/2012.

CÂMARA DOS DEPUTADOS. Projeto de Lei N. 2.330/2011. Emenda de Plenário N. 54. Ivan Valente (PSOL/RJ) Brasília. 28/03/2012. 
CÂMARA DOS DEPUTADOS. Projeto de Lei N. 2.330/2011. Emenda de Plenário N. 56. Deputado Ivan Valente (PSOL/SP) Brasília. 28/03/2012.

CÂMARA DOS DEPUTADOS. Projeto de Lei N. 2.330/2011. Emenda de Plenário N. 27. Vicentinho (PT/SP) Brasília. 28/03/2012.

CÂMARA DOS DEPUTADOS. Projeto de Lei N. 2.330/2011. Emenda de Plenário N. 1. do Deputado Vanderlei Macris (PSDB/SP). Brasília. 28/03/2012.

CÂMARA DOS DEPUTADOS. Projeto de Lei N. 2.330/2011. Emenda de Plenário N. 2. do Deputado Vanderlei Macris (PSDB/SP). Brasília. 28/03/2012.

CÂMARA DOS DEPUTADOS. Projeto de Lei N. 2.330/2011. Emenda de Plenário N. 31. Deputado Onofre Santo Agostini (PSD/SC). Brasília. 28/03/2012.

CÂMARA DOS DEPUTADOS. Projeto de Lei N. 2.330/2011. Emenda de Plenário N. 41. Deputado Marcelo Aguiar (PSD/SP) Frente Parlamentar Evangélica. Brasília. 28/03/2012.

CÂMARA DOS DEPUTADOS. Projeto de Lei N. 2.330/2011. Emenda de Plenário N. 50. Deputados Chico Alencar (PSOL/RJ), Ivan Valente (PSOL/SP) e Jean Wyllis (PSOL/RJ). Brasília. 28/03/2012.

CÂMARA DOS DEPUTADOS. Projeto de Lei N. 2.330/2011. Emenda de Plenário N. 15. Deputada Carmen Zanotto (PPS/SC). Brasília. 28/03/2012.

CÂMARA DOS DEPUTADOS. Projeto de Lei N. 2.330/2011. Emenda de Plenário N. 66. Deputado Vanderlei Macris (PSDB/PE). Brasília. 28/03/2012.

CÂMARA DOS DEPUTADOS. Projeto de Lei N. 2.330/2011. Emenda de Plenário N. 61. Deputado Paulo Pimenta (PT/RS). Brasília. 28/03/2012.

CÂMARA DOS DEPUTADOS. Projeto de Lei N. 2.330/2011. Emenda de Plenário N. 15. Deputada Carmen Zanotto (PPS/SC). Brasília. 28/03/2012.

CÂMARA DOS DEPUTADOS. Regimento Interno. Atualizado até a Resolução nº 50, de 2013. Brasília.

CONGRESSO. CÂMARA DOS DEPUTADOS DO BRASIL. Discurso de Plenária. Deputada Clair Martins (PT-PR). 22/12/2003. Disponível em <www.camara.gov.br/sileg/integras/178226.doc> Acesso em 10/10/2013.

CONGRESSO. SENADO FEDERAL. Regimento Interno: Resolução $n^{\circ}$ 93, de 1970. Brasília: Senado Federal.

Brasília, 5 de outubro de 1988.

. CONSTITUIÇÃO DA REPÚBLICA FEDERATIVA DO BRASIL, 
DIÁRIO DA CAMARA DOS DEPUTADOS. Deputado CHICO ALENCAR (PSOL-RJ). Data: 28/03/2012.

DIÁRIO DO CONGRESSO NACIONAL. (Seção I) Março de 1982. P. 1559. LEGISLAÇÃO. ESTATUTO DO TORCEDOR. LEI 10.671/2003. Diário Oficial da União.16.5.2003. Brasília.

Exposições de Motivos $N^{\circ}$ 15. 16 de Setembro de 2011. Subchefia de Assuntos Parlamentares. Assinado por: Ministro do Estado do Esporte, Orlando Silva de Jesus Júnior; Ministro do Estado das Relações Exteriores, Antonio de Aguiar Patriota; Ministro do Estado do Trabalho (interino) Paulo Roberto dos Santos Pinto; Ministro do Estado da Justiça, José Eduardo Martins Cardozo; Ministro do Estado da Fazenda, Guido Mantega; Ministro do Estado do Desenvolvimento, Indústria e Comércio Exterior, Fernando Damata Pimentel; Ministro do Estado das Comunicações, Paulo Bernardo Silva; Ministra do Estado da Cultura, Anna Maria Buarque de Hollanda; Advogado-Geral da União, Luis Inacio Lucena Adams; Ministra do Estado do Planejamento, Orçamento e Gestão, Miriam Aparecida Belchior.

Fiscalização da Copa 2014 do TCU - Disponível em: <http://portal2.tcu. gov.br/portal/page/portal/TCU/copa2014> Acesso em 25/08/2013.

Instrução Normativa ${ }^{\circ} 1.293$, de 21 de setembro de 2012 - Dispõe sobre o despacho aduaneiro de bens procedentes do exterior destinados à utilização na Copa das Confederações FIFA 2013 e na Copa do Mundo FIFA 2014, de que trata esta Lei.

LEGISLAÇÃO. LEI No 10.683, DE 28 DE MAIO DE 2003.

$\begin{array}{cccrcr}\text { Internacionais. } & \text { Ministério das Relações } & \begin{array}{r}\text { Exteriores. } \\ \text { Disponível }\end{array} & \text { em } & \text { Tramitação } & \begin{array}{c}\text { de Atos } \\ <\text { http://dai- }\end{array}\end{array}$ mre.serpro.gov.br/clientes/dai/dai/apresentacao/tramitacao-dos-atos-internacionais >

Acesso em : 11/11/13.

Ministério das Relações Exteriores. Sistema Eletrônico de Serviço ao cidadão. Protocolo: 09200.000283/2013-31. Mensagem recebida por ciceroluz@gmail.com em 12/7/2013.

Ministério de Estado das Relações Exteriores. Ministro Celso Amorim. Garantia No 1: Permissões para Entrada e Saída. 28 de maio de 2007.

Ministério de Estado do Trabalho e Emprego. Garantia No2: Permissões de Trabalho. Ministro Ronaldo Lessa (interino). Carta N 287 / GM. 14 de junho de 2007.

Ministério de Estado da Fazenda. Garantia No 3: Direitos Alfandegários e Impostos. Ministro Guido Mantega. Junho de 2007 (sem referência ao dia). 
Ministério de Estado da Fazenda. Garantia $\mathbf{N}^{\mathbf{0}}$ 4: Isenção Geral de Impostos. Ministro Guido Mantega. Junho de 2007 (sem referência ao dia).

Ministério de Estado de Justiça. Garantia N 5: Segurança e Proteção. Ministro Tarso Genro. 29 de maio de 2007.

Ministério de Estado da Fazenda. Garantia N. ${ }^{\circ}$ 6: Bancos e Câmbio. Ministro Guido Mantega. Junho de 2007 (sem referência de dia).

Ministério de Estado da Fazenda, Guido Mantega, Ministério do Estado da Justiça, Tarso Genro e Ministério de Estado da Defesa, Waldir Pires. Garantia N.7: Procedimento de Imigração, Alfândega e Check-in. Respectivamente: Guido Mantega, Tarso Genro, Waldir Pires. Junho de 2007 (sem referência de dia).

Ministério de Estado de Justiça, Ministério de Estado do Desenvolvimento, Indústria e Comércio Exterior, Ministério de Estado da Cultura , Ministério de Estado da Ciência e Tecnologia. Garantia N.8: Proteção e Exploração de Direitos Comerciais. Respectivamente: Tarso Genro, Miguel Jorge, João Luiz Silva Ferreira, Sergio Machado Rezende. 29 de maio de 2007.

Ministério de Estado das Relações Exteriores. Ministro Celso Amorim. Garantia N 9: Hinos e Bandeiras Nacionais. 28 de maio de 2007.

Ministro de Estado da Advocacia Geral da União. Garantia No 10: Indenização. José Antonio Dias Toffoli.15 de junho de 2007.

Ministério de Estado das Comunicações. Garantia $\mathbf{N}^{\mathbf{0}}$ 11: Telecomunicações, Tecnologia da Informação.Hélio Costa. 29 de maio de 2007.

Ministério Das Relações Exteriores do Brasil, DAI - Divisão de Atos Internacionais. Prática Diplomática Brasileira - Manual de Procedimentos. Brasília, maio de 2010.

\begin{tabular}{c} 
Ministério \\
\hline <mario.coutinho@camara.gov.br> $>$ e recebida por ciceroluz@gmail.com em 04/05/12.
\end{tabular}

População não quer bebida alcoólica na Copa e $62 \%$ defendem feriado para os jogos. DataSenado, 11 abr 2012. Disponível em:

<http://www.senado.gov.br/noticias/datasenado/release_pesquisa.asp?p=39>, acesso em 8 abr. 2013.

Acesso em 20/09/2013.

Portal da Copa. Disponível em: <http://www.copa2014.gov.br/>.

Portal da Transparência. Disponível em:

<www.portaltransparencia.gov.br/copa2014>. Acesso em 20/09/2013.

SENADO FEDERAL. DIÁRIO DO SENADO FEDERAL. Parecer $\mathbf{N}^{\mathbf{0}}$

861/2002, da Comissão de Constituição Justiça e Cidadania. Quinta-feira, 8 de Agosto de 2002. 
SENADO FEDERAL. DiÁRIO DO SENADO FEDERAL. Proposta de emenda à Constituição $\mathbf{N}^{\mathbf{0}}$ 52, 2001. Sexta-feira, 30 de Novembro de 2001.

SENADO FEDERAL. DIÁRIO DO SENADO FEDERAL. Requerimento $\mathbf{N}^{\mathbf{8}}$ 825/2003. Senador Aloizio Mercadante. Quinta-feira, $18 \mathrm{de}$ Setembro de 2003.

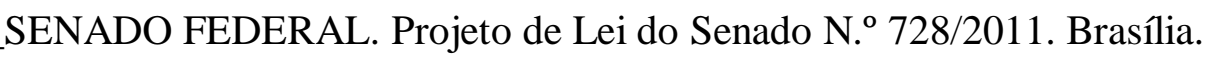

SENADO FEDERAL. SSCLSF - SUBSEC. COORDENAÇÃO LEGISLATIVA DO SENADO PEC - PROPOSTA DE EMENDA À CONSTITUIÇÃO, $\mathbf{N}^{\mathbf{5}} 52$ de 2001. Situação: ARQUIVADA AO FINAL DA LEGISLATURA. Matéria arquivada ao final da 52 $2^{\mathrm{a}}$ Legislatura, nos termos do art. 332 do Regimento Interno e do Ato $\mathrm{n}^{\circ}$ 97, de 2002, do Presidente do Senado Federal. Disponível em: <http://www.senado.gov.br/ atividade/materia/detalhes.asp?p_cod_mate=49034> Acesso em 10/10/2013.

BROWNLIE, Ian. Princípios de Direito Internacional Público. Lisboa: Fundação Calouste Gulbenkian, 1997.

CACHAPUZ DE MEDEIROS, Antônio Paulo. O poder de celebrar tratados. Competência dos poderes constituídos para a celebração de tratados, à luz do Direito Internacional, do Direito Comparado e do Direito Constitucional Brasileiro. Porto Alegre, Sergio Antonio Fabris Editor, 1995.

Antonio Paulo. O poder legislativo e os Tratados Internacionais. Porto Alegre: LPM, 1983.

CÂMARA DOS DEPUTADOS. Agência Câmara Notícias. Parlasul adia eleições diretas de parlamentares do Mercosul para 2020. Disponível em $<\mathrm{http}$ //www2.camara.leg.br/camaranoticias/noticias/RELACOES-

EXTERIORES/458455-PARLASUL-ADIA-ELEICOES-DIRETAS-DE-

PARLAMENTARES-DO-MERCOSUL-PARA-2020.html> Acesso em 4/12/13.

Agência de Notícias da Câmara. Disponível em <http://agenciacamara.justica.inf.br/noticia/2003/8/frente-da-alca-reune-se-daqui-a-pouco> Acesso em 10/10/13.

CAMARGO, Sonia de. Governança Global: utopia, desafio ou armadilha? In: Governança Global: Reorganização da política em todos os níveis de ação. Centro de Estudos Konrad-Adenauer-Stiftung. n. 16. São Paulo: 1999.

CAMPILONGO, Celso Fernandes. O direito na sociedade complexa. $2^{\mathrm{a}}$ Ed. São Paulo: Saraiva, 2011.

CANOTILHO, J. J. Gomes. Direito Constitucional e teoria da constituição. Coimbra: Almedina, 2003. 
CARBONE, Maurizio. "Supporting or Resisting Global Public Goods? The Policy Dimension of a Contested Concept", Global Governance - A Review of Multilateralism and International Organization. vol. $13 \mathrm{n}^{\circ}$ 2, 2007 pp.179-198.

CASINI, Lorenzo. The Making of a Lex Sportiva by the Court of Arbitration for Sport. German Law Journal 12, no. 5. 2011. pp.1317-1340.

CASTELLS, Manuel. A galáxia da internet. Reflexões sobre a internet, os negócios e a sociedade. Rio de Janeiro: Jorge Zahar, 2003.

CASTRO NEVES, João Augusto de. O Papel do Legislativo nas Negociações do Mercosul e da ALCA. Contexto Internacional 25.1. 2003.103-138.

CATTONI DE OLIVEIRA, Marcelo Andrade. Do processo legislativo: uma justificação democrática do controle jurisdicional de constitucionalidade das leis e do processo legislativo. Belo Horizonte, Mandamentos, 2000.

CELli JUNIOR, U. A Constituição, o Parlamento e a política externa brasileira. Publicado em Correio Internacional. 2003.

CEPS, EGMONT, EPC Joint Study. The Treaty of Lisbon: A second Look at the Institutional Innovations. Bruxelas, 2010.

CHARBONNEAU Louis. Bud faces tough taste test in World Cup Germany. Agência Reuters. SPORTS ESPN. Publicado 7 de junho de 2006 Disponível em $<$ http://sports.espn.go.com/espn/wire?section=soccer\&id=2438139> $>$ acesso em $10 / 10 / 13$.

COMISSÃO EUROPEIA. Assuntos Econômicos e Financeiros. O euro. Disponível em < http://ec.europa.eu/economy_finance/euro/index_pt.htm $>$ Acesso em: 10/10/13.

Dossiê interinstitucional: 2005/0167 (COD) MIGR 41CODEC 750

$\begin{array}{llllll}\text { COMIX } & 579 & \text { Data: } 5 & \text { de } & \text { setembro }\end{array}$

<<http://register.consilium.europa.eu/pdf/pt/05/st12/st12125.pt05.pdf $>>$

Comitê Popular dos Atingidos pela Copa 2014. Disponívelm em

<http://atingidoscopa2014.wordpress.com/>; Acesso em 23/10/2013.

COMPARATO, Fábio Konder. A Afirmação Histórica dos Direitos Humanos. São Paulo: Editora Saraiva. 1999.

CONFEDERAÇÃO BRASILEIRA DE FUTEBOL. BID BOOK. Declaração de Ricardo Teixeira. P. 3-4. Rio de Janeiro, 13 de abril de 2007.

CONSELHO DA UNIÃO EUROPEIA. Dossier interinstitucional: 2005/0167 (COD)

CODEC 1630 MIGR 119 COMIX 856. Data: 2 dezembro de 2008.

CONVENÇÃO DE VIENA SOBRE O DIREITO DOS TRATADOS, 1969. 
COSTA, Olivier; DRI, Clarissa. "L’Union européenne peut-elle être démocratique? La participation aux élections au Parlement européen." Revista de estudos constitucionais, Hermenêutica e teoria do direito 2.12010.

SAINT MARTIN, Florent; Le Parlament européen. La Documentation Française, Paris, 2009.

COURT OF ARBITRATION FOR SPORT. (Tribunal Arbitral Do Esporte). Arbitration CAS 2011/O/2574 Union des Associations Européennes de Football (UEFA) v. FC Sion/Olympique des Alpes SA, award of 31 January 2012 (operative part of 15 December 2011).

COX, Robert. "Social forces, states and world orders: beyond international relations Theory". In: KEOHANE, Robert. The neorealism and its critics. New York: Columbia, 1986.

DAHL, Robert. Can international organizations be democratic? A skeptics's view. In: Shapiro, Ian \& Hacker-Cordon, Casiano (eds.) Democracy's Edges. Cambridge University Press, 1999, pp. 19-40.

p.100-130. 1998.

On Democracy, New Haven: Yale University Press, Part III cap.9- 11,

DALLARI, Pedro. Constituição e Relações Exteriores. São Paulo: Editora Saraiva, 1994.

DAVID, René. Os grandes sistemas do direito contemporâneo. 4. ed. São Paulo : Martins Fontes, 2002.

DE LIMA, Maria Regina Soares. A política externa brasileira e os desafios da cooperação Sul-Sul. Revista Brasileira de Política Internacional 48.1,2005. 24-59.

DE SOUSA SANTOS, Boaventura. O Fórum Social Mundial: manual de uso. Cortez Editora, 2005.

DELMAS-MARTY, Mireille,.. Estudios jurídicos comparados e internacionalización del derecho. Revista Penal Publicado por Librairie Arthème Fayard 2003, Paris.

Fayard, 2006;

; et al. Pour un nouvel imaginaire politique. Paris: Librairie Arthème

Por um direito comum. São Paulo, Martins Fontes, 2004.

Etudes juridiques comparatives et internationalisation du droit. Collection: Leçons inaugurales du Collège de France. Paris: Fayard, 2003.

Três Desafios para um Direito Mundial. Tradução Fauzi Hassan Choukr. Rio de Janeiro: Editora Lumen Juris, 2003. 
DIAEY, Taha; DUFOURG, Jérôme; J. TJUŠEVS, Pāvels; GARAVELLI, Alberto Zamboni. Bidding: How can you win even if you lose? Identifying the legacies of lost bids to host a sports mega event. CIES. Disponível em http://doc.rero.ch/record/24858/files/2011_Bidding_how_can_we_win_if_we_lose.pdf

Acesso em 11/11/10.

DINGWERTH, Klaus; PATTBERG, Philipp. Global Governance as a Perspective in World Politics. Global Governance - a Review on Multilateralism and International Organizations, vol.12, no. 2, April-June 2006. P.185-203.

DIP, Andrea. Projeto de lei quer punir 'terroristas' e grevistas durante a Copa. Carta Capital. Disponível em <http://www.parlamento.pt/europa/ PublishingImages/Documentos/TLx_PNs.pdf> Acesso em 11/11/13.

DORMOY, Daniel. Droit des organisations internationales. Paris: Dalloz, 1995.

DRI, Clarissa Franzoi . La construction du Parlement du Mercosur: le poids des institutions, des intérêts et des idées. Études Internationales (Québec), v. XLIV, p. 177-196, 2013.

Limits of the Institutional Mimesis of the European Union: The Case of the Mercosur Parliament. Latin American Policy, v. 1, p. 52-74, 2010.

Building the Mercosur Parliament: integration on European patterns? Heidelberg Papers in South Asian and Comparative Politics, v. 59, p. 155-170, 2011.

Funcionalidade parlamentar nas experiências européia e andina: quais perspectivas para o Mercosul? Novos Estudos Jurídicos v. 14, p. 169-184, 2009.

As funções do parlamento entre o Estado-nação e a integração regional: esgotamento orgânico ou adaptação institucional? Revista de Ciências Humanas. N. 39. Florianópolis, EDUFSC, p. 83-98, abril de 2006.

GARNET Workshop Parliaments in regional integrations (PAREGI), Bordeaux, March 242010.

MALAMUD, Andrés. Spillover Effects and Supranational Parliaments: The Case of Mercosur. Journal of Iberian and Latin American Research V. 19.2. p. 224238. 2013.

DRUMMOND, Maria Claudia. O déficit democrático e as instituições parlamentares internacionais. In: Brasil, União Europeia, América do Sul: anos 2010 - 2020. Rio de Janeiro: Fundação Konrad Adenauer, 2009. p. 160-180.

DUPUY, René-Jean. O Direito Internacional. Livraria Almedina. Coimbra, 1993. DWORKIN, Ronald. A New Philosophy for International Law. Philosophy \& Public Affairs, 41: 2-30. 2013.

ERTEN, S. Spatial analysis of mega-event hosting: Olympic host and Olympic bid cities, Tese de Doutorado. Middle East Technical University, 2008. 
EUROLAT. ASSEMBLEIA PARLAMENTAR EURO-LATINO-AMERICANA. REGLAMENTO. 25/01/13. Disponível em http://www.europarl.europa.eu/intcoop/eurolat/key_documents/rules_of_procedure 2013/926146es.pdf> Acesso em 01/07/13.

Documentos e Eventos. Disponível em < http://www.europarl.europa.eu/ $>$ Acesso em 01/07/13.

EUROPA - PRESS RELEASES - Press Release - An effective and humane return policy: 8 Member States have yet to comply with the Return Directive. Disponível em << europa.eu/rapid/press-release_IP-11-1097_en.htm >>

FERRAZ JUNIOR, Tercio Sampaio. Estudos de Filosofia do Direito: reflexões sobre o poder, a liberdade, a justiça e o direito. $2^{a}$ Ed. São Paulo: Atlas, 2003.

FERREIRA FILHO, Manoel Gonçalves, Do Processo Legislativo. $4^{\mathrm{a}}$ Edição. São Paulo: Editora Saraiva, 2001.

FIANI, Ronaldo. Teoria dos Jogos: com aplicações na economia, administração e ciências sociais. 3a Ed. Rio de Janeiro: Elsevier, 2009.

FIFA - Federação Internacional de Futebol. Disponível em: <www.fifa.com> Acesso em: 20/09/2013.

Bidding Agreement. Regarding the Submission of bids for the right to host and stage the 2018 FIFA WORLD CUP or 2022 FIFA WORLD CUP. Zurich, Suíça. p. 37.

Disciplinary Code. Edição 2011.

Estatuto da FIFA. Edição: Julho de 2013.

FIFA Code of Ethics. Edição 2012.

Safety Regulations. Zurique, Suíça. 2013.

Fifa Media Releases. Disponível em http://www.fifa.com/worldcup/ organisation/media/medialist.html. Acesso em 10/9/2013.

FINANCIAL REPORT. 63rd Congress. Muritius, Maio de 2013. p. 16.

FIGUEIRA, A.C.R. Processo Decisório em Política Externa no Brasil. Tese de doutorado. Faculdade de Filosofia, Letras e Ciências Humanas: Universidade de São Paulo: São Paulo. (2009).

FIGUEIREDO, A.C. \& LIMONGI, F.. Executivo e Legislativo na nova ordem constitucional. Rio de Janeiro, FGV, 1999. 
FOLHA DE SÃO PAULO. Após ameaça, torcedor do Inter retira a ação contra a CBF.

Folha Online. Esporte. 09/12/2005. Disponível em: <http://www1.folha.uol.com.br/folha/esporte/ult92u96309.shtml > Acesso em 20/12/2012.

FORBES. Sports Money. The Ten Highest-Paying Sporting Events In The World. 6/5/13. Disponível em: <http://www.forbes.com/sites/monteburke/2013/06/05/the-tenhighest-paying-sporting-events-in-the-world/> Acesso em 10/10/13.

FORUM INTERPARLAMENTAR DAS AMÉRICAS. Relatorio apresentado pelo Forum das Américas FIPA a V Cúpula de Chefes de Estados e Governos das Américas. Trinidad e Tobago, 2009. Disponível em <www.summitamericas.org/V.../CS/fipa_report_pt.pdf $>$ Acesso em 11/08/13.

FOSTER, Ken. Is There a Global Sports Law? Entertainment Law, Vol.2, No.1, Londres: Frank Cass, Spring 2003, p.1-18.

Lex Sportiva and Lex Ludica: the Court of Arbitration for Sport's Jurisprudence Entertainment and Sports Law Journal 3. Vol. 2. 2005. pp. 1-15.

FRAGA, Mirtô. O conflito entre tratado internacional e norma de direito interno: estudo analítico da situação do tratado na ordem jurídica brasileira. Rio de Janeiro: Forense, 1997.

FRANCHINI-NETTO, M. Projeto de Lei n. ${ }^{\circ}$ 5.974/1982, que dispõe sobre a participação de representantes oposicionistas em missão oficial brasileira no exterior. Brasília, 1982. In: MEDEIROS, Antônio Paulo Cachapuz (Org.) Pareceres dos Consultores Jurídicos do Itamaraty. Vol VIII (1972-1984). Brasília: Senado Federal, 2004. pp. 358-361.

FRANCO, Giuliana Silva. Diplomacia parlamentar no Brasil: Participação Direta nas Decisões Internacionais. In: Diplomacia Parlamentar - Uma Contribuição ao Debate. Instituto Universitas. Brasília-DF: DGrau Multimídia Ltda, 2008.

FRIZZERA, Guilherme. A suspensão do Paraguai no MERCOSUL: problema interno, solução externa Conjuntura Global, Curitiba, Vol. 2, n.3, jul./set., 2013.

GOLDAMMER, Eberhar von. PAUL, Joachim. Gotthard Günther Annotations 2004/1. Vordender. Sommer-Eddition 2004.

GOLDSMITH, Jack L.; POSNER Eric A.The Limits of International Law. Oxford: Oxford University Press, 2005.

GÖTZ, Norbert. On the Origins of 'Parliamentary Diplomacy' Scandinavian 'Bloc Politics' and Delegation Policy in the League of Nations Cooperation and Conflict: Journal of the Nordic International Studies Association Vol. 40(3): 263-279. 2005.

GRANT, Ruth \& KEOHANE, Robert. Accountability and Abuses of Power in World Politics. The American Political Science Review, vol. 99, n 1, February 2005, pp. 2943. 
GREWE, Wihelm, The Epochs of International Law. Berlin: Walter de Gruyter, 2000 .

GROS, Frédéric. Estados de violência: ensaio sobre o fim da guerra. Aparecida / SP: Idéias \& Letras, 2010.

GÜNTHER, Gotthard. Life as Poly-Contexturality. In: Beiträge zur Grundlegung einer operationsfähigen Dialektik, vol. 2. Hamburg: Meiner 1979, pp. 283-306.

HABERMAS. J. Consciência Moral e Agir Comunicativo Rio de Janeiro: Tempo Universitário, 1989.

HABERMAS. J. Direito e Democracia entre facticidade e validade. Vol. 1. $2^{\text {a }}$ Edição. Rio de Janeiro: Tempo Universitário, 2003.

HALL, Michael C. Urban entrepreneurship, corporate interests and sports mega-events: the thin policies of competitiveness within the hard outcomes of neoliberalism. The Editorial Board of the Sociological Review. Published by Blackwell Publishing Ltd. 2006. EUA.

HART, Herbert. O conceito de direito. Traduzido por A. Ribeiro Mendes. 3 ed. Lisboa: Fundação Calouste Gulbenkian, 2001.

HÖFFE, Otfried. A democracia no Mundo de Hoje. São Paulo, Martins Fontes, 2005. http://www.europarl.europa.eu/oeil/popups/summary.do?id=1040487\&t=d\&l=en

HUNTINGTON, Samuel. The third wave: democratization in the late twentieth century. University of Oklahoma Press, 1991.

HURRELL, Andrew. One world? Many worlds? The place of regions in the study of international society. International Affairs 83: 1 (2007) 127-146.

ILLES, P.; VENTURA, D. F. L. . Qual a política migratória do Brasil?. Le Monde Diplomatique (Brasil), São Paulo, SP, p. 34 - 35, 07 mar. 2012.

INSTITUTO BRASILEIRO DE DEFESA DO CONSUMIDOR

<www.idec.org.br/campanhas/copasemdireitos>; Acesso em 23/10/2013.

INTERNATIONAL PARLIAMENTARY UNION. Disponível em <<http://www.ipu.org>> Acesso em 12.11.12.

JENNINGS, Andrew. Jogo Sujo: o mundo secreto da FIFA: compra de votos e escândalo de ingressos. Tradução Renato Marques de Oliveira. São Paulo: Panda Books, 2011.

JIMENEZ, Carlos. Diplomacia parlamentar. Diplomacia Parlamentar - Uma Contribuição ao Debate. Instituto Universitas. Brasília-DF: DGrau Multimídia Ltda, 2008. 
JORNAL DA CAMARA. Lara Haje. Brasília, 3 de Novembro de 2011.

JUSTIÇA GLOBAL. Santo Antônio de Jesus, 15 anos de impunidade. Tragédia dos fogos de artifícios. 6 DE SETEMBRO DE 2013. Disponível em <http://global.org.br/programas/santo-antonio-de-jesus-15-anos-de-impunidadetragedia-dos-fogos-de-artificios/> Acesso em 7/10/13.

KAELBLE, Hartmut. Les Chemins de la Démocratie Européenne. Paris: Editions Berlin, 2005.

KAUL, INGE, GRUMBERG, ISABELLE \& STEIN, Marc (Eds.) Defining Public Goods e Global Public Goods: concepts, policies and strategies. Global Public Goods. International Cooperation in the $21^{\text {st }}$ century. New York: Oxford University Press: 1999.

KELSEN, Hans. Teoria Geral do Direito e do Estado. $3^{\text {a }}$ Ed. São Paulo: Martins Fontes, 1998.

KELSEN, Hans. Teoria pura do direito. 6. ed. Traduzido por João Baptista Machado. São Paulo: Martins Fontes, 1998.

KEOHANE, Robert; GRANT, Ruth. Accountability and Abuses of Power in World Politics. The American Political Science Review, vol. 99, nº 1, February 2005, pp. 2943.

KEOHANE, Robert; MACEDO, Stephen; MORAVSCIK, Andrew. "DemocracyEnhancing Multilateralism.” International Organization, vol. 63, nº 1, Winter 2009, pp. 1-31.

KISSINGER, Henry A. Diplomacy. New York: Simon and Schuster, 1994.

KOSKENNIEMI, M. International Law-Making: problems of coherence and fragmentation. A summary of the Chatham House International Law discussion group meeting held on 23 March 2007;

International legislation today: Limits and possibilities, Wisconsin International Law Journal Vol. 23, No. 1, 2008.

The Lady Doth Protest Too Much: Kosovo and the Turn to Ethics in International Law, 65 The Modern Law Review, 2002.

The Police in the Temple: Order, Justice and the UN: A Dialectical View. European Journal of International Law, 6 (3). 1995. 325-348.

Vol.1. 2011.

What use for sovereignty today? Asian Journal of International Law.

KRASNER, Stephen D. Rethinking the sovereign state model. Review of International Studies Vol. 27, no. 05. 2001. 17-42. 
LAGASSE, Charles-Étienne. Les institutions Européennes après le traité de Lisbonne. Bruxelas : Étidions Erasmus, 2010.

LANDLER, Mark. The Hard Sell in Frankfurt. The New York Times. Publicado 7 de junho de 2006. Disponível em <http://www.nytimes.com/2006/06/07/business/media/07adco.html?pagewanted=all> Acesso em 10/10/13;

LIJPHART, Arend. Modelos de Democracia, Rio de Janeiro, Civilização Brasileira, 2003.

LINKLATER, A.. "The achivement of critical theory", In: International theory: positivism and beyond. S Smith; K. Booth; M. Zalewski. Cambridge: Cambridge University Press, 1996.

LINZ, Juan. Presidencialismo ou Parlamentarismo: Faz alguma diferença? LAMOUNIER, Bolívar et al. (Org.) A Opção Parlamentarista, São Paulo: Sumaré, p.61-120. 1991.

LUHMANN, Niklas, Eı Derecho de La Sociedad. Tradução Javier Torres Nafarrate. México: Editorial Herder, 2005.

A terceira questão - O Uso criativo dos paradoxos no Direito e na história do Direito. Estudos Jurídicos. Vol. 39 N. 1. Jan-Jun Tradução: Cícero Krupp da Luz; Jéferson Luiz Dutra.. São Leopoldo: Universidade do Vale do Rio dos Sinos, 2006. p.45-52.

A restituição do décimo segundo camelo: do sentido de uma análise sociológica do direito. in: ARNAUD, André-Jean; LOPES Jr., Dalmir. Niklas Luhmann: Do Sistema Social à Sociologia Jurídica. Rio de Janeiro: Editora Lumen Juris, 2004.

La Sociedad de la Sociedad. Tradução Javier Torres Nafarrate. Cidade do México: Editorial Herder, 2007.

Legitimação pelo procedimento. Tradução de Maria da Conceição Corte-Real. Brasília, UnB, 1980.

Poder. Tradução Martine C. Rezende Martins. Brasília: Editora da Universidade de Brasília, 1985.

Universidad, 2002.

Teoría política en el Estado de Bienestar. Madrid: Alianza

LUZ, Cícero Krupp da. A policontexturalidade da lex mercatoria: contingência, paradoxo e decisão. Dissertação de Mestrado. 2009. $171 \mathrm{f}$.

MAGNETTE, Paul. Le régime politique de I'Union européenne. $2^{\circ}$ Editión. Paris: Presses de Sciences Po, 2006 
MANIN, Bernard. Frontières, Freins et Contrepoids: La Séparation des pouvoirs dans le débat constitutionnel américan de 1787. Revue française de science politique, Année 1994, Volume 44, Numéro 2. p. 257 - 293.

MARCONDES FILHO, Ciro. O escavador de silêncios: formas de construir e desconstruir os sentidos da comunicação. Nova Teoria da comunicação II. São Paulo: Paulus, 2004.

MARTINS, Carlos Eduardo. O Golpe de Estado no Paraguai e a América do Sul. Carta Maior. 24/06/2012.

MATHESON, Victor. Mega-Events: The effect of the world's biggest sporting events on local, regional, and national economies. College Of The Holy Cross, Department Of Economics Faculty Research Series, Paper 06-10, 2006.

MAZZUOLI, Valério de Oliveira. Curso de direito internacional público. São Paulo: RT. 2010.

MEARSHEIMER, John J. The tragedy of great power politics. New York/London: W.W Norton and Company, 2001.

MEDEIROS, M. A. ; PAIVA, M. E. ; LAMENHA, Marion . Legitimidade, Representação e Tomada de Decisão: O Parlamento Europeu e o Parlasul em Perspectiva Comparada. Revista Brasileira de Política Internacional, v. 55, p. 154-173, 2012.

União Europeia, reformas institucionais e déficit democrático: uma análise a partir do mecanismo de co-decisão. Revista Brasileira de Política Internacional 52.12009.

MELlo, Celso Antônio Bandeira. Curso de Direito Administrativo - $29^{a}$ Ed. Malheiros: São Paulo, 2012.

MERCOSUL. Protocolo de Montevidéu sobre Compromisso com a Democracia no Mercosul (Ushuaia II), Dezembro de 2011.

MERCOSUR/CMC/DEC. No28/12. Regulamentación de los aspectos operativos de La Suspensión de La Republica Del Paraguay. In: MERCOSUR: < http://www.mercosur.int/innovaportal/file/3862/1/dec 028-

2012_es_reglam_suspension_parag uay.pdf> Acesso em 2 de outubro de 2013.

MESSARI. Nizar; NOGUEIRA, João Pontes. Teoria das Relações Internacionais. Correntes e Debates. Rio de Janeiro: Elsevier, 2005.

MILANI, Carlos R. S.; PINHEIRO, Leticia. Política externa brasileira: os desafios de sua caracterização como política pública. Contexto int., Rio de Janeiro , v. 35, n. 1.

MILNER, Helen. Interest, institutions and information: domestic politics and international relations. Princenton: Princeton University Press, 1997. 
MONTESQUIEU, Charles de Secondat. Espírito das Leis. São Paulo: Martins Fontes, 1996.

MORAVSCIK, Andrew. Is there a 'Democratic Deficit' in World Politics? A Framework for Analysis' Government and Opposition - An international Journal of Comparative Politics, vol. 39, n. 2 2004, p. 336-364.

MORGENTHAU, H. Política entre as nações. Brasília, UNB/Imprensa Oficial SP, 2003. ; Paulo: Martins Fontes, 1998.

NAÇÕES UNIDAS. Programa das Nações Unidas para o Desenvolvimento. Innovative Financing for Development: A New Model for Development Finance? Nova Iorque: January 2012.

NANZ, Patricia e STEFFEK, Jens. "Global Governance, Participation and the Public Sphere". Government and Opposition - An International Journal of Comparative Politics, vol. 39, no. 4, 2004.

NASSER, Salem Hikmat. Fontes e Normas do Direito Internacional: Um estudo sobre a SOFT LAW. São Paulo: Editora Atlas, 2005.

NAYYAR, Deepak. 'Towards Global Governance'. Governing Globalization: issues and institutions. Oxford: Oxford UP, 2002. P. 3-18.

NEGOCIO, Ramon Vasconcelos de. Lex Sportiva Da autonomia Jurídica ao diálogo transconstitucional. Dissertação. PUC-SP. São Paulo, 2011.

NEVES, João Augusto de Castro. O papel do legislativo nas negociações do Mercosul e da Alca. Contexto Internacional. Vol. 25 n. 1 Rio de Janeiro Jan/Junho de 2003.

NEVES, Marcelo. Transconstitucionalismo. São Paulo: Martins Fontes, 2009

Fontes, 2007.

Constitucionalização Simbólica. $2^{\mathrm{a}}$ Ed. São Paulo: WMF Martins

Entre Têmis e Leviatã: uma relação difícil: o Estado Democrático de Direito a partir e além de Luhmann e Habermas. São Paulo: Martins Fontes, 2006.

OCDE. Organização para a Cooperação e Desenvolvimento Econômico. Growing Unequal? : Income Distribution and Poverty in OECD Countries. OECD Publishing, 2008.

OLIVEIRA, Rodrigo Regazonni. O Congresso Nacional e a Política Externa Brasileira. Posicionamento dos senadores frente às negociações para a formação da ALCA (19942005). 2011. 138f. Dissertação Programa de Pós-Graduação em História, UNB. Brasília, 2011.

ONUKI, Janina, OLIVEIRA, A. J. S. N.;. Política comercial e Legislativo: a atuação do empresariado brasileiro. In: MANCUSO, Wagner Pralon; LEOPOLDI, Maria 
Antonieta; IGLECIAS, Wagner. (Org.). Estado, empresariado e desenvolvimento no Brasil: novas teorias, novas trajetórias. 1 ed. São Paulo: Editora da Cultura, 2010, v. 1, p. 1-23.

ORGANIZAÇÃO DAS NAÇÕES UNIDAS. Assembleia Geral. 66 ${ }^{\mathrm{a}}$ Sessão. 11 Reunião. GA/11245. Referências a resoluções A/66/L.45 e A/66/770. 29/5/2012. Department of Public Information, New York.

Assembleia Geral. 15 ${ }^{\mathrm{a}}$ Sessão. Declaration on the granting of independence to colonial countries and peoples. Resolução 1.514, de 14/12/1960.

Carta das Nações Unidas. São Francisco, 26 de junho de 1945.

Rules of Procedure. Embodying amendments and additions adopted by the General Assembly up to September 2007. A/520/Rev.17. New York, 2008.

ORGANIZAÇÃO DOS ESTADOS AMERICANOS. Assembleia Geral. RESOLUÇÃO 1673/99. Vigésimo Nono Período Ordinário de Sessões Guatemala. De 6 a 8 de junho de 1999. Atas e documentos volume I. Secretaria-Geral. Washington, D.C. 20006.

Corte Interamericana De Direitos Humanos. Caso Ximenes Lopes versus Brasil. Sentença de 4 de julho de 2006. Mérito, Reparações e Custas. (Caso 12.237) San José, Costa Rica.

OST, François. O tempo do Direito. Tradução Maria Fernanda Oliveira. Lisboa: Instituto Piaget. 1999.

PAHN, Paul Bernds. The Tobin Tax and Exchange Rate Stability. Finance \& Development. Junho. 1996. Trabalho original: TOBIN, James, 1978, A Proposal for International Monetary Reform, Yale University, Eastern Economic Journal.

PARLAMENTO EUROPEU. 〈http://www.europarl.europa.eu/parliament>

Comissão das Liberdades Cívicas, da Justiça e dos Assuntos Internos. Relator: Manfred Weber PROJECTO DE RELATÓRIO. EXPOSIÇÃO DE MOTIVOS. 13.6.2006. (COM(2005)0391 - C6-0266/2005 - 2005/0167(COD)).

Comunicado de Imprensa: Parlamento Europeu aprova directiva de retorno. Disponível em: <http://www.europarl.europa.eu/news/expert/infopress_page/018-31787-168-06-25902-20080616IPR31785-16-06-2008-2008-true/default_pt.htm> Acesso em 06.07.09

Legislative Observatory. 2005/0167(COD) - 18/06/2008

PAZ, Sérgio Miranda. O Futebol como patrimônio cultural do Brasil: estudo exploratório sobre possibilidades de incentivo ao Turismo e ao Lazer. São Paulo, 2006. 245f. Tese (Doutorado) -- Escola de Comunicação e Artes da Universidade de São Paulo. Departamento de Relações Públicas, Propaganda e Turismo. Universidade de São Paulo, São Paulo, 2006. 
PECES-BARBA MARTÍNTEZ, Gregório. Primera parte: Sentido y contenido de la Declaración de 1789 y textos posteriores. In: PECES-BARBA MARTÍNTEZ, Gregório; FERNÁNDEZ GARCIA, Eusebio; DE ASÍS ROIG. Historia de los Derechos Fundamentales. Tomo. II: Siglo XVIII Vol. III. Madrid: Editorial Dukinson S. L., 2001.

PEERS, Steve. Statewatch Analisys. Junho 2008. http://www.detention-ineurope.org/images/stories/june\%202008\%20statewatch\%20analysis\%20on\%20return\% 20directive.pdf

PEREIRA, Carlos; MUELLER, Bernardo. Uma Teoria da Preponderância do Poder Executivo: o sistema de comissões no sistema brasileiro. REVISTA BRASILEIRA DE CIÊNCIAS SOCIAIS - VOL. 15 No. 43. junho/2000.

PIANTA, Mario. UN World Summits and Civil Society. The State of the Art. United Nations Research Institute for Social Development. 2005.

PIELKE, R., How can FIFA be held accountable?. Sport Management Review (2013), http:// dx.doi.org/10.1016/j.smr.2012.12.007

PILLAY, Udesh; BASS, Orli.Mega-events as a Response to Poverty Reduction: the 2010 FIFA World Cup and its Urban Development Implications. Urban Forum 19:329-346. 2008.

PINHEIRO, Leticia; HIRST, Monica. A política externa do Brasil em dois tempos. Revista Brasileira de Política Internacional 38.1, 1995. pp. 5-23.

PIRIS, Jean-Claude. The Lisbon-Treaty: a legal and political analysis. Cambridge studies in European Law and policy. Cambridge, Reino Unido.

PORTUGAL. Assembleia da República. O TRATADO DE LISBOA E OS PARLAMENTOS NACIONAIS Comissão de Assuntos Europeus. 2013.

PRIETO, Noé Cornago. O outro lado do novo regionalismo pós-soviético e da ÁsiaPacífico. In: VIGEVANI, Tullo (Org.). A dimensão subnacional e as relações internacionais. São Paulo: Unesp, 2004, p. 252-252.

PRZEWORSKI, Adam, et. al, Economic development and political regimes. Cambridge: Cambridge University Press, 2003.

PUIG, Lluis Maria de. Les parlaments internationaux. Editions Du Conseil de L’Europe. Strasbourg, 2008.

PUTNAM, Robert. Diplomacy and domestic politics. The logic of two-level games, International Organization, Vol. 42, n. 3. 1988.

QVORTRUP, Lars. The Hypercomplex Society. New York: Peter Lang Publishers, 2003. p. 16.; TEUBNER, Gunther. The King's Many Bodies: The Self-Deconctruction of Law's Hierarchy. Law and Society Review, Volume 31. Number 4. 1997. p.763787. 
RANGEL, Marcelo de Mello; PEREIRA, Mateus Henrique de Faria; Valdei Lopes de Araujo (orgs). O giro-linguístico e a historiografia: balanço e perspectivas. Ouro Preto: EdUFOP, 2012.

REIS, H. H. B. Futebol e sociedade: as manifestações da torcida. Tese de Doutorado em Educação Física - Faculdade de Educação Física, Universidade Estadual de Campinas, Campinas, 1998.

RAY, R. Parliamentary Diplomacy. New Delhi: Chand. 1991.

REZEK, J.F. As relações Internacionais na Constituição da Primeira República. Arquivos do Ministério da Justiça. Jun. 1975.

RITCHIE, B., Assessing the Impact of Hallmark Event: Conceptual and Research Issues, Journal of Travel Research, Vol. 23, 1984.

ROCHA, Leonel Severo. O Direito na forma de sociedade globalizada. In: Epistemologia Jurídica e Decisão. 2a Ed. São Leopoldo: Editora UNISINOS, 2002.

ROMERA, L. A.; REIS H. H. B. Uso de álcool entre torcedores. Motriz, Rio Claro, v.15, n.3, p.541-551, jul./set. 2009.

ROSENAU, James N. 'Governance, order, and change in world politics'. Rosenau, James; Czempiel, Ernst-otto (eds.). Governance without Government: Order and Change in World Politics. Cambridge: Cambridge UP, 2000. P.1-29

ROSENAU, James. "Norms". Along the Domestic-Frontier. Exploring Governance in a Turbulent World. Cambridge Studies in International Relations, ${ }^{\circ}$ 53. Cambridge: Cambridge University Press, 1997, pp. 174-188.

RUGGIE, John G. "Reconstituting the Global Domain - Issues, Actors, and Practices". European Journal of International Relations, vol. 10, n 4, December 2004, pp. 499531.

RUSK, D. Parliamentary Diplomacy - Debate vs. Negotiation, World Affairs Interpreter. 1955, 26: 121-38.

SALDANHA, Nelson. O Estado Moderno e a Separação de Poderes. São Paulo: Saraiva, 1987.

SANCHEZ BADIN, M. R. . Atores não-estatais e sua relação com a Organização Mundial do Comércio. In: Alberto do Amaral Junior. (Org.). Direito do Comércio Internacional. 1ed.Sao Paulo: Editora Juarez de Oliveira, 2002, v. 1, p. 151-170.

; SILVA, E. C. G. S. ; CARDOSO, Evorah Lusci Costa ; SPÉCIE, Priscila . Política Externa como política pública: uma análise pela regulamentação constitucional brasileira 1967/1988. Revista de Sociologia e Política, v. 27, p. 13-29, 2006. 
Breves consideraciones sobre los los mecanismos de participación de las

ONGs en la OMC. Sur. Revista Internacional de Direitos Humanos. São Paulo, v. 4, n.3, p. 105-127, 2006.

SANTOS, Fabiano; VILAROUCA, Márcio. Adesão da Venezuela ao Mercosul: Desideologizar como forma de atingir o Interesse Nacional. Papéis Legislativos. n.4. 2007.

SANTOS, Lindinalva dos, VELLOSO, Tatiana Ribeiro Velloso. Aprendizados no Processo de Construção de Alternativas de Inclusão Social do Grupo do Movimento 11 de Dezembro no Município de Santo Antonio de Jesus-BA. NAU Social 3.5 63-68, 2012.

SAURON, Jean-Luc. Le Parlement européen. Paris : Gualino éditeur, 2009.

SCHOLTE, Jan Aart. "Civil Society and Democratically Accountable Global Governance". Government and Opposition - An International Journal of Comparative Politics, vol. 39, no. 4, 2004.

SECRETARIA DEL MERCOSUR. Instrumentos Fundamentales Del Mersocur. Sector de normativa, documentación y divulgación, Montevideo, Uruguai. 2012.

SHARP, Paul. Revolutionary States, Outlaw Regimes and the Techniques of Public Diplomacy.; MELISSEN, Jan (Org.) The new public diplomacy. Palgrave Macmillan, 2005.

SHAW, Malcolm. International Law. Cambridge: University Press, 2008.

SILVA, José Afonso da. Processo Constitucional de Formação das Leis. $2^{\mathrm{a}}$ ed. São Paulo: Malheiros, 2006.

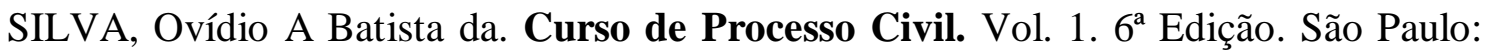
Editora Revista dos Tribunais, 2002. P. 14.

Forense, 2004.

Processo e ideologia: o paradigma racionalista. Rio de Janeiro:

SIMIONI, Rafael Lazzarotto. "Organização do poder político: o estado constitucional em Niklas Luhmann. Prismas: Dir., Pol. Publ. e Mundial., Brasília, v. 6, n. 2, p. 329349, jul./dez. 2009.

SKJÆRSETH, Jon Birger.;STOKKE, Olav Schram; WETTESTAD, Jørgen. Soft Law, Hard Law, and Effective Implementation of International Environmental Norms. Global Environmental Politics 6:3, August 2006.

SLAUGHTER, Anne-Marie. International Law in a World of Liberal States Vol. 6 European Journal of International Law 503-53. 1995.

STARCK, P. Soccer World Cup to boost German 2006 GDP - Study, The Guardian, 01/12/2005. 
STAVRIDIS, Stelios. "Parliamentary Diplomacy": some preliminary findings. Jean Monnet Working Papers in Comparative and International Politics. November 2002 - JMWP n 48.

Parliamentary Diplomacy. Any Lessons for regional parliaments? 2007. Disponível em: <http://www. agora-parl. org/node/1288> Acesso em $12 / 10 / 2012$.

AJENJO, Natalia. EU-Latin American Parliamentary relations: some preliminary comments on the EUROLAT. Jean Monnet/Robert Schuman Paper Series Vol. 10, No. 3, April 2010.

PACE, Roderick. Regional Parliaments in the Euro-Mediterranean Region: does it amount to Integration? Garnet, Bordeaux, 24 March, 2010.

STEFFEK, Jens. Global Governance, Participation and the Public Sphere. Government and Opposition - An International Journal of Comparative Politics, vol. 39, no. 4, 2004.

SUPREMO TRIBUNAL FEDERAL. ADI 1480. MC, Relator: Min. CELSO DE MELLO, Tribunal Pleno, julgado em 04/09/1997, DJ 18-05-2001 PP-00429 EMENT VOL-02031-02 PP-00213.

ADI 4976. Despacho Ministro RICARDO LEWANDOWSKI - Relator, julgado em 18/06/2013, publicado em PROCESSO ELETRÔNICO DJe-119 21/06/2013. Brasília, 18 de junho de 2013.

SZASZ, Paul. Improving the International Legislative Process. Journal of International and Comparative Law. p.519, 1979.

TELESUR. Senado de Paraguay aprueba ingreso de Venezuela al Mercosur. 10 de Dezembro de 2013. Disponível em: http://www.telesurtv.net/articulos/2013/12/10/senado-de-paraguay-aprueba-ingreso-devenezuela-al-mercosur-5486.html Acesso em 12/12/2013.

TEUBNER, Gunther. "And God Laughed..." Indeterminacy, Self-reference, and Paradox In Law. Stanford Literature Review. N. 7.

Breaking Frames: Economic Globalization and the Emergence of the lex mercatoria. European Journal of Social Theory. 5(2): 199-217.

Global Bukowina: Legal Pluralism in the World Society. In: Gunther Teubner (ed.) Global Law Without a State. Dartmouth: Aldershot, 1996. p. 3-28.

TEUBNER, Gunther. The King's Many Bodies: The Self-Deconctruction of Law's Hierarchy. Law and Society Review, Volume 31. Number 4. 1997 .p.763-787.

TOMLInSON, Alan; YOUNG Christopher. Culture, Politics, and Spectacle in the Global Sports Event An Introduction. National Identity and Global Sports Events: 
Culture, Politics and Spectacle in the Olympics and the Football World Cup. Albany: State University of New York Press, 2006.

TRIBUNAL ARBITRAL DO ESPORTE (CAS). Jurisprudência. Arquivo. Disponível em: $\quad<$ http://jurisprudence.tas-cas.org/sites/CaseLaw/ Shared\%20Documents/Forms/PerSport.aspx $>$ Acesso em 20/09/2013.

Code 2013. (Estatuto 2013). Estatuto dos organismos que trabalham para a Resolução de Disputas Esportivas. Suíça, 01/03/2013.

TRIBUNAL DE JUSTIÇA DO RIO GRANDE DO SUL. $1^{\text {a }}$ Vara Cível do Foro Central Processo Número: 001/1.05.2429826-6. Arquivado - Caixa 8396. 01/12/2007.

TUCH, Hans. Communicating With the World: US Public Diplomacy Overseas. Nova Iorque: St Martin's Press, 1990.

UNIAO EUROPEIA, TRATADO DE FUNCIONAMENTO DA UNIAO EUROPEIA, 2009.

UNIAO EUROPEIA. PROTOCOLO RELATIVO AO PAPEL DOS PARLAMENTOS NACIONAIS NA UNIÃO EUROPEIA. Jornal Oficial da União Europeia. C 310/204. 16.12.2004.

PROTOCOLO RELATIVO AO PAPEL DOS PARLAMENTOS NACIONAIS NA UNIÃO EUROPEIA. Jornal Oficial da União Europeia. C 310/204. 16.12.2004.

VARELLA, Guilherme. Copa sem direitos não dá jogo. Carta Capital. 11/10/2011. Disponível em:<www.cartacapital.com.br/politica/a-lei-geral-da-copa-cria-um-estadode-excecao-em-relacao-a-defesa-do-consumidor> Acesso em 23/10/2013.

VEJA, Cerveja da Copa renova com Fifa. E ganha força para 2014. 25/10/2011. Disponível em < http://veja.abril.com.br/noticia/esporte/cerveja-da-copa-renova-comfifa-e-ganha-forca-para-2014> Acesso em 10/10/13.

VENTURA, D. F. L.. As Assimetrias entre o MERCOSUL e a União Européia - os desafios de uma associação interregional. 1. ed. São Paulo: Manole, 2003.

MIOLA, I. Z. . Os efeitos da transnacionalização sobre a governança regional: o caso da conflituosa implantação da indústria de celulose no Cone Sul da América. Contexto Internacional PUCRJ. Impresso., v. 31, p. 391-427. 2009.

FONSECA, M. G. . Posibilidades y límites a la participación de los entes subnacionales en la política exterior de Brasil y en los procesos de integración regional. Revista CIDOB d'Afers Internacionals v. 99, p. 55-73, 2012.

VENTURA, Deisy; PEROTTI, Alejandro D. El Proceso Legislativo der Merscosur. KONRAD-ADENAUER-STIFTUNG E. V.: Montevideo, Uruguay, 2004. 
SEITENFUS, Ricardo Antônio Silva. Introdução ao direito internacional público. $3^{\text {a }}$ Ed. rev. ampl. Porto Alegre: Livraria do Advogado, 2003.

WAHL, Peter. "No, they can't!" The potential and limitations of the EU (as a supranational state in the making) to reform finance and overcome the crisis. PSL Quarterly Review, vol. 65 n. 263. 2012. 403-427.

WALTZ, K. O Homem, o estado e a Guerra. São Paulo: Martins Fontes, 2004.

Man, The State and War. Columbia University Press, 1959.

Teoria das Relações Internacionais. Lisboa: Gradiva, 2002.

WELSCH, Wolfgang. Mudança estrutural nas ciências humanas: diagnóstico e sugestões. Educação, n. 2 (62), p. 237-258, maio/ago. Porto Alegre/RS: Editora PUCRS, 2007.

Rationality and Reason Today. Scholarly Publications Cornell, 20003;

ZANIRATO, Sílvia Helena. Patrimônio da Humanidade: Controvérsias Conceituais e Legais In: ENCONTRO NACIONAL DA ANPPAS, 5, 201. Anais do V ENCONTRO NACIONAL DA ANPPAS. 2010, Florianópolis.

ZIZEK, Slavoj. O violento silêncio de um novo começo. In: HARVEY, David... et al.(Org.) Occupy. São Paulo, Boitempo. 2012.

ZURN, Michael. Global Governance and Legitimacy Problems. Government and Opposition - An International Journal of Comparative Politics, vol. 39, no. 4, 2004. 